I.AISA ISA I:OSTA FFERISFEIIA

ARU(J)THES

:III.ITARTH

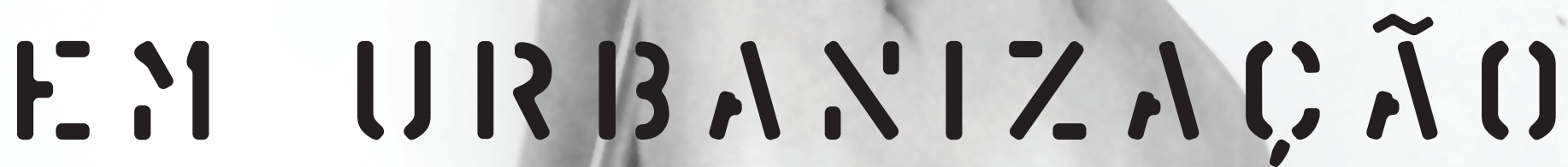

I) FE REFEI-AS

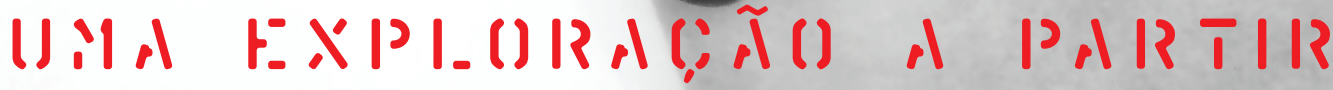

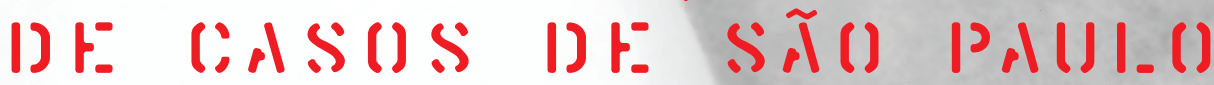

$F_{-}^{-}$I)(I $15 I()$ I) 


\title{
ARQUITETOS MILITANTES EM URBANIZAÇÃO DE FAVELAS \\ UMA EXPLORAÇ̃̃O A PARTIR DE CASOS DE SÃO PAULO E DO RIO DE JANEIRO
}

\author{
LARA ISA COSTA FERREIRA \\ DISSERTAÇ̃̃O DE MESTRADO
}

\author{
FACULDADE DE ARQUITETURA E URBANISMO DA \\ UNIVERSIDADE DE SÃO PAULO - FAUUSP \\ Programa de Pós-Graduação em Arquitetura e Urbanismo \\ Área de Concentração: HABITAT \\ Linha de Pesquisa: Formas de Provisão na Edificação, \\ Urbanização e Infra-Estrutura \\ Orientadora: KARINA OLIVEIRA LEITÃO
}


Autorizo a reprodução e divulgação total ou parcial deste trabalho, por qualquer meio convencional ou eletrônico, para fins de estudo e pesquisa, desde que citada a fonte.

EMAIL DA AUTORA: lara.icf@gmail.com

Catalogação na Publicação

Serviço Técnico de Biblioteca

Faculdade de Arquitetura e Urbanismo da Universidade de São Paulo

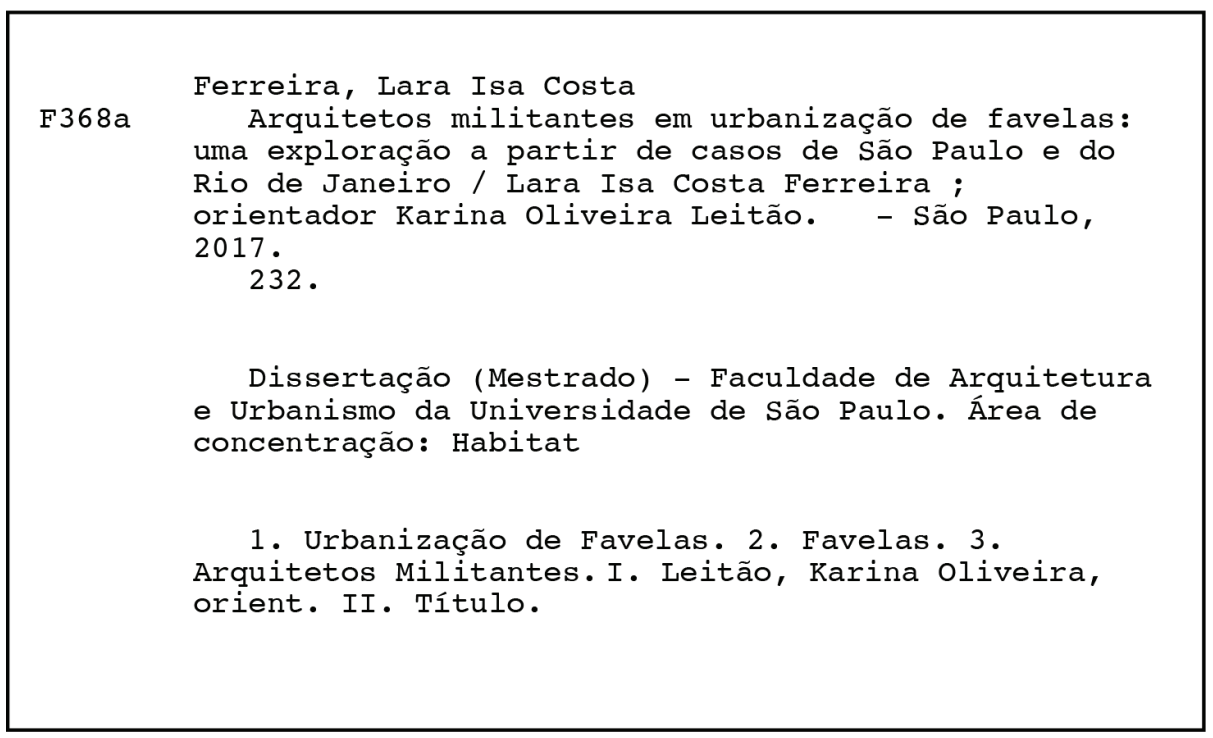




\section{ARQUITETOS MILITANTES EM URBANIZAÇÃOO DE FAVELAS UMA EXPLORAÇÃO A PARTIR DE CASOS DE SÃO PAULO E DO RIO DE JANEIRO}

Dissertação apresentada à Faculdade de Arquitetura e Urbanismo da Universidade de São Paulo para obtenção do título de Mestre em Arquitetura e Urbanismo

APROVADO EM:

BANCA EXAMINADORA

Prof. Dr.:

Instituição:

Julgamento:

Assinatura:

Prof. Dr.:

Instituição:

Julgamento:

Assinatura:

Prof. Dr.:

Instituição:

Julgamento: Assinatura: 

À resistência, resiliência e luta. Aos que sabem, aos que suspeitam e aos que têm a certeza que são militantes. 


\section{AGRADECIMENTOS}

Em primeiro lugar, quero agradecer aos meus Pais, porque me proporcionaram tudo o que tenho hoje e tudo o que alcancei. Quero agradecer-lhes também a compreensão da distância. Um agradecimento estendido a todos os que estão longe, entre família e amigos, por saberem que esta distância é consequência da minha busca por aquilo que acredito.

A todos os que me acolheram aqui, entre famílias emprestadas - Vieira, Tedeschi, Ro e $\mathrm{Lu}$, a amigos de mais velha ou nova data. A eles o meu obrigada por fazerem do Brasil e de São Paulo também o meu lar.

Esta pesquisa é resultado de todas as práticas, trabalhos, apresentações, conversas, discussões e reflexões sobre o tema da intervenção em favelas em que participei nos últimos três anos, feita por aqueles que acreditam e são engajados na luta por cidades mais justas, igualitárias e emancipadas.

Obrigada Paulo Moreira, Hugo Mesquita, B Arquitetos e Observatório de Remoções, e todos os seus integrantes, por me proporcionarem experiências de trabalho que me aproximaram como arquiteta e urbanista do que eu quero fazer como arquiteta e urbanista. Também à Paloma e Felipe que partilharam comigo o desafio de pensar a arquitetura e urbanismo com os membros da Unas de Heliópolis e Região, a eles também o meu muito obrigada. E a todos os restantes moradores de assentamentos que pelo Brasil (e pelo mundo) partilharam comigo suas histórias, seus cafés, suas casas, suas favelas.

A todos que partilharam comigo mesas e horas de trabalho sobre favelas nos últimos 3 anos, em especial a todos os participantes e convidados da I Oficina: Favelas. O meu muito obrigada, principalmente às queridas Bárbara Muhle, Thalissa Burgi e Beatriz Nobumoto. Sem vocês este trabalho seria metade do que está aqui!

Vocês me inspiram a fazer mais e melhor todos os dias!

A todos os entrevistados - sujeitos militantes - por quem nutro tremendo afeto e admiração e me inspiram diariamente para a militância: Helo, Vera, Milton, Usina, Jonathas, Toledo, Manoel, Peabiru, e Carlos Nelson que, infelizmente, não tive o privilégio de conhecer pessoalmente, apenas por palavras. Obrigada pelas vossas cedências de tempo, conversas, material, mas acima de tudo, pelo vosso trabalho e mobilização técnica, social e política. O que está aqui espera ser fruto e reconhecimento de tudo isso. Um agradecimento especial a todos os membros da Peabiru, pelo acolhimento. Todos vocês são sujeitos imbuídos de estética, técnica e ética, mas acima de tudo amor pelo que fazem. Espero que este trabalho faça jus ao que encontrei nas nossas conversas, nos vossos desenhos, nas vossas ações. 
Ao grupo de estudo GE_Favelas, entre todos participantes e convidados, um grupo que me acolheu na discussão e na partilha sobre como se faz, como se tem feito, e como se pode fazer urbanização de favelas. Neste agradecimento incluo especialmente a Lu Ferrara e José Baravelli que contribuíram, na qualificação, para a abertura desafiante de caminhos de pesquisa, alguns dos quais percorremos e apresentamos aqui.

Um obrigada muito especial ao LabLaje - Felipe, Paula, Rodrigo, Victor e Vitor. Estes anos não seriam os mesmos sem vocês, estas reflexões não seriam as mesmas sem vocês, esta tentativa de militância, não seria a mesma sem vocês. Se opto por escrever na $\mathrm{I}^{\mathrm{a}}$ pessoa do plural, faço-o reconhecendo neste um processo coletivo de pesquisa que se estende às nossas conversas de bar, de sala de aula, de sala de estar, de Oficina (afinal somos um só). Esta dissertação também é vossa. Espero que vá ao encontro de tudo o que vocês são e me ensinam a ser.

O meu eterno agradecimento ao Gabriel, por me acompanhar há 3 anos, e me instigar todos os dias a ser e fazer melhor. Sou mais politizada, sou mais consciente e, com certeza, mais feliz porque estás ao meu lado. Muito obrigada pelas cedências, principalmente d('os últimos) tempo(s), para terminar essa empreitada comigo.

E, por fim, mas o mais importante, um agradecimento especial à minha orientadora Karina Leitão, com quem tive o privilégio de aprender, conhecer, refletir, sobre favelas, sobre precariedade habitacional, sobre militância, e com ela transformar esses mesmos conceitos inúmeras vezes. Obrigada pela orientação, inspiração, amizade, e, porque não, amor! Espero que aceites este, como um trabalho também teu.

Esta pesquisa contou com apoio CAPES - Coordenação de Aperfeiçoamento de Pessoa de Nível Superior, através de bolsa de mestrado, desde agosto de 20 I 5 . 


\section{RESUMO}

O foco desta pesquisa é a atuação de arquitetos e urbanistas militantes em urbanização de favelas. Para tal recorremos a casos concretos de experiências de urbanização de favelas com a participação destes técnicos na Região Metropolitana de São Paulo e Município do Rio de Janeiro da década de 60 aos anos 20 I 0. Pretendemos desta forma olhar para este campo de atuação do arquiteto e urbanista, mas focando naqueles que historicamente têm exercitado intervenções mais justas, mais integradoras, mais emancipadas em favelas. Trata-se de um reconhecimento da atuação destes arquitetos - sujeitos políticos, mas também a apresentação de uma retrospectiva sobre as suas práticas, muitas vezes pioneiras no seu campo de atuação. Trata-se também de uma reflexão sobre os alcances e limites da sua ação militante. Selecionamos sujeitos que se destacam nessa atuação e cujas experiências que acontecem num tensionamento entre técnica, estética e ética. Na prática, os resultados são por vezes limitados, e muitas vezes frustrantes, mas ao mesmo tempo, seguramente inspiradores. A partir dos seus relatos e reflexões, mesmo que em contexto muito diversificados, encontramos pontos de contato nas metodologias, nas ações e nas intenções e que denominamos como práticas militantes em urbanização de favelas. Com esta pesquisa propomos um mapeamento de possíveis referências, mas também o questionamento sobre o lugar do arquiteto frente a territórios de conflito.

PALAVRAS CHAVE: Urbanização de Favelas, Favelas, Arquitetos Militantes. 


\section{ABSTRACT}

This research focus on the action of militant architects and urban planners in what regards slum upgrading processes in favelas from the 6o's to the io's decades. In order to do so, we resort to concrete cases of slum upgrading experiences in favelas that counted upon the participation of theses subjects in the metropolitan region of São Paulo, as well as in the municipality of Rio de Janeiro. We aimed at regarding this field of action of architects and urban planners focusing on the professionals that have been proposing interventions that seek to be more just, more integrated, and more emancipated in favelas. This work intends to recognize the background of these architects - understood as political subjects herein - but also, to approach a retrospective abou their experiences that usually reveal to be pionneer in their professional field. It also aims at analyising the limits and advances of their militant action. We have chosen professionals that stand out in their field of action, and whose experiences stress the boundaries of ethics, aesthetics and techinique. In the end, the results of their experiences are rare, generally frustrating, but at the same time, surely inspiring. We have built our analysis upon their oral information and their own relfections over their experience, and, despite the different contexts, we have come to common points in terms of methods, practice and inteverntions, that we have have designated as militant practices in slum upgranding. Through this research, we present a mapping of possible references, but also a questioning over the role of architects in territories of conflicts.

KEY-WORDS: slum upgrading, favelas, militant architects 



\section{SUMÁRIO}

\section{PARTE ZERO}

Apresentação

Introdução

\section{PARTE UM}

CAP.1 Arquitetos Militantes em Urbanização de Favelas

Um tensionamento entre Estética, Técnica e Ética

CAP.2 As Possibilidades da Militância Projetista dentro de um Percurso Histórico

\section{PARTE DOIS}

CAP.3 Práticas Militantes na Urbanização de Favelas

As reflexões sobre a(s) prática(s)

\section{PARTE TRÊS}

Notas Conclusivas

Referências 



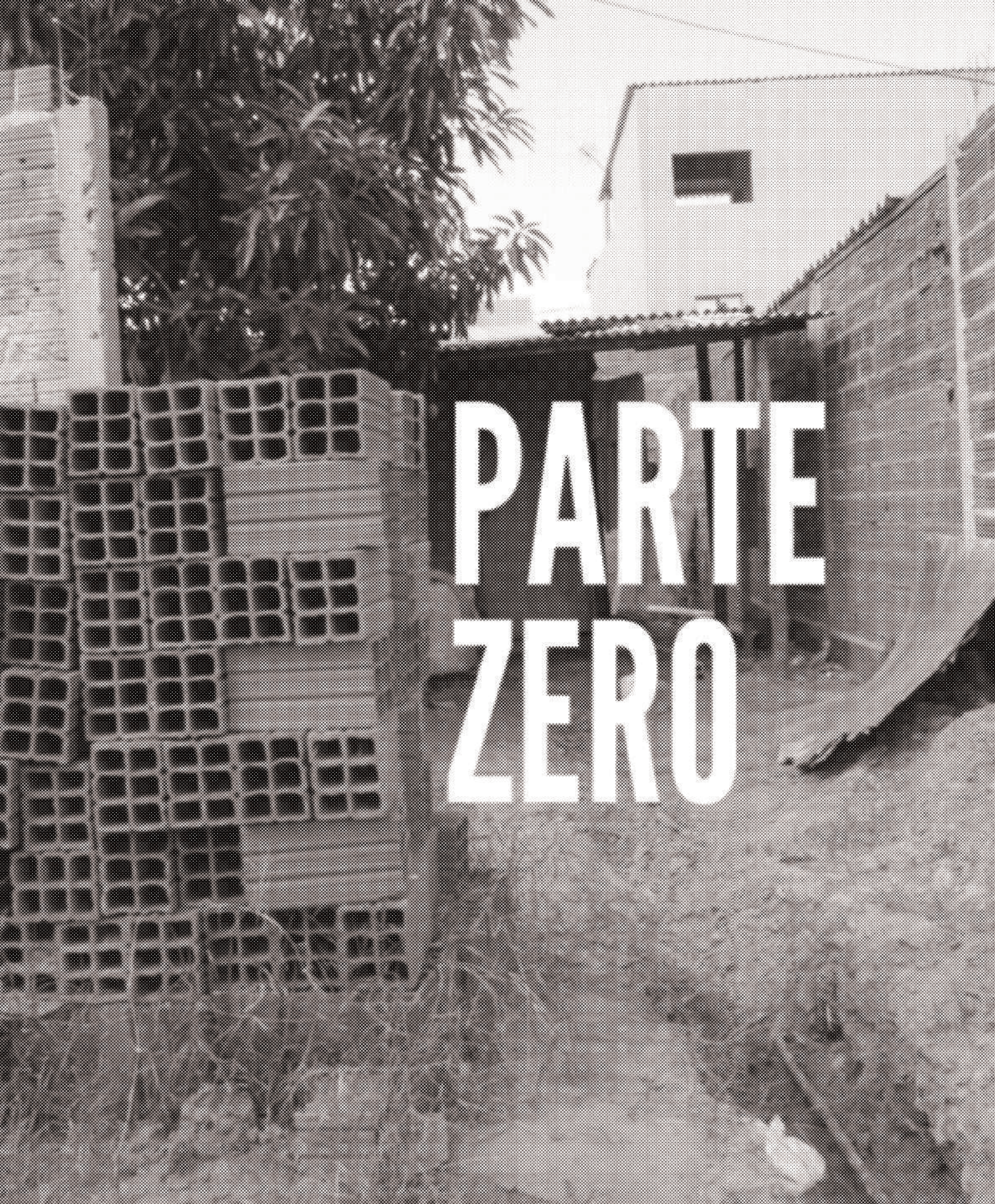




\section{APRESENTAC̣̃̃O}

A pesquisa aqui apresentada resulta do meu percurso pessoal de experiências, motivações e procuras.

Um percurso que se inicia em Portugal na "Escola de Arquitectura do Porto", a FAUP' ${ }^{1}$, com algumas passagens por diferentes experiências internacionais de interesse social ${ }^{2}$ e estudos em São Paulo ${ }^{3}$.

Inquietações sempre foram motivando a minha procura por experiências e práticas. No encontro entre a minha formação técnica, em arquitetura e urbanismo, e as imagens de diferentes processos de desenvolvimento espelhados nos territórios, principalmente aqueles de maior precariedade que conheci pessoalmente, fosse numa favela no Brasil, numa aldeia remota timorense ou numa habitação de ilha ${ }^{4}$ do Porto, era relembrada constantemente que as minhas ferramentas deveriam ser utilizadas no sentido da reversão dessas situações, para mim injustas, muitas vezes inexplicáveis, e todas as vezes inaceitáveis.

Esta inquietação trouxe-me de volta a São Paulo em 20 I 3, na busca por experiência profissional e formação especializada no campo de atuação em assentamentos precários. Entre experiências de apoio a pesquisas acadêmicas ${ }^{5}$, em 20 I 3 iniciei uma colaboração em um dos projetos dentro do Programa de Urbanização de Favelas da Prefeitura de São Paulo, junto com um dos escritórios vencedores do concurso RENOVA-SP em 20 I I $^{6}$.

Esta experiência possibilitou-me pela primeira vez a participação num projeto com proposta de intervenção física em favelas, para além da pesquisa, como tinham sido as anteriores. Foi um acúmulo de conhecimento e de muitos sentimentos opostos. A frustração, pelas limitações técnicas e burocráticas que foram impostas ao longo do processo, é talvez a sensação que mais permanece. No entanto esse sentimento foi sempre balanceado com o de realização encontrado no processo de aprendizagem, onde pude acumular a gestão de projetos e disciplinas complementares à arquitetura e urbanismo, a investigação e a descoberta de técnicas e ferramentas desconhecidas por mim até então, e o desenvolvimento de propostas que acreditávamos serem as mais adequadas ao território e sua população.
I. Faculdade de Arquitectura da Universidade do Porto (FAUP). Entre 2004 a 2010 frequentei e concluio Mestrado Integrado em Arquitectura, nesta instituição. 2. Desde 2007, fui voluntária em Organizações Não Governamentais de ação social no Porto e em São Paulo, deslocando-me inclusivamente a Timor-Leste em 2007 e 2010 para missões humanitárias no âmbito da educação para o desenvolvimento.

3. Entre 2008-2009 frequentei a FAUUSP durante 3 semestres consecutivos por um periodo de intercâmbio no âmbito do programa de mobilidade da minha formação na FAUP. Em 2013 regressei a São Paulo já formada.

4. A ilha é um tipo de habitação precária característica da cidade do Porto (Portugal), semelhante à morfologia de cortiços das cidades brasileiras. A proliferação das ilhas coincide com o momento de industrialização da cidade (segunda metade do XIX). Com a Revolução de 1975 e a democratização do país e suas lutas sociais, o poder público investiu na sua redução e na melhoria de condições habitacionais

5. Entre 20 I I 20 I 3 , colaborei na pesquisa do arquiteto português, Paulo Moreira, doutorando na London Metropolitan University, em Londres, sobre um assentamento informal em Luanda, capital angolana - a Chicala (www.chicala.org e www.paulomoreira.net). De 2013 a 2014 colaborei com outra pesquisa de doutorado do arquiteto português, Hugo Mesquita, para a ETH (Eidgenössische Technische Hochschule Zürich), sobre morfologia de assentamentos precários em São Paulo (e-collection.library.ethæ.ch/view/eth:49889). A pesquisa consistia na visita, levantamento $e$ desenho de habitações em favelas, e nesta experiência contribui com alguns desenhos para a favela Jardim 
Colombo e o trabalho de campo e gráfico da Vila

Clara, ambas na Zona Sul do munícipio de São

Paulo.

Em 2016, integrei a equipe do Observatório de

Remoções - projeto da FAUUSP e UFABC, que

denuncia e acompanha processos de remoção

da região metropolitana de São Paulo - para

acompanhar o caso Água Espraiada, que consiste

num caso onde cerca de 50 assentamentos

precários e suas populações estão ameaçados de remoção. Para mais informações consultar wñn.

observatorioderemocoes.fau.usp.br. para a população mais

pobre. Ainda que com melhores condições, algumas

famílias ainda residem nesta tipologia de habitação,

algumas em situação de muita precariedade.

6. O escritório B Arquitetos, em colaboração como

Zehbra Arquitetos participou do concurso Renova SP em 20 I I, sendo selecionado para o desenvolvimento dos projetos básicos de Urbanização de Favelas para duas áreas da Zona Norte da cidade de São

Paulo. Desde 2012 até ao momento, o B Arquitetos

desenvolve projetos de arquitetura, urbanismo e

coordenação de restantes projetos complementares

da área PAI (Perímetro de Ação Integrada) Cabuçu

de Baixo 4. Em 20I6, voltei a acompanhar um dos

processos do Renova SP, desta vez no PAI Cordeiro

I, na Zona Sul, em colaboração com o escritório Inter

Urbano. Para mais informações sobre o concurso,

programa e propostas, ver:

enovasp.habisp.inf.br/concurso/info/apresentacao .
Quanto ao sentimento: frustração, ele vai permear esta pesquisa, e será encontrado junto dos restantes arquitetos projetistas que aqui tomarão o papel de sujeitos de pesquisa. Suas causas, contextos e práticas aparecerão nos casos apresentados e encaminhandonos para a análise a que esta pesquisa se propõe.

Esta experiência levou-me a outra busca. A de referências de Urbanização de Favelas, por projetos, desenhos e soluções técnicas, formas de fazer e experiências executadas que poderiam servirme de inspiração, reflexão e aprendizado sobre a possibilidade de transformação (ou no mínimo) intervenção em lugares, procurando torná-los mais salubres, mais adequados, mais integrados e mais justos para a população moradora e para a cidade como um todo.

A clareza das características do tipo de Urbanização de Favela que procurava esbarrou na dificuldade para encontrá-las, pelo menos num primeiro momento. Se por um lado é evidente a vasta experiência acumulada no Brasil sobre Urbanização de Favelas, com casos desde os anos 70, e integrados em políticas públicas a partir do período de redemocratização do país, por outro tratamse de experiências pouco detalhadas e publicizadas, e de difícil acesso, no que diz respeito ao campo da arquitetura e urbanismo, no sentido da apresentação de soluções técnicas e estéticas, de desenho multidisciplinar e de compatibilização de disciplinas complementares, campo onde sentia maior necessidade por referenciais.

Associo, em parte, esta lacuna de conhecimento e de referências da atuação do arquiteto na coordenação de disciplinas e, sobretudo, na atuação sobre territórios complexos onde questões sociais se misturam com a morfologia, às grades curriculares que tive acesso enquanto aluna de graduação. Ao mesmo tempo, na minha formação a busca por referências foi introduzida como uma das metodologias de desenvolvimento de qualquer processo de arquitetura e urbanismo. A procura por referências foi então o primeiro passo de aproximação à pesquisa aqui apresentada. 
Um segundo passo, foi a possibilidade de integração, desde o início da sua formação, no Grupo de Estudo de Urbanização de Favelas - o GE_Favelas. Formado em 20 I 4 por alunos de pós-graduação do Programa de Pós-Graduação em Planejamento Urbano da Universidade Federal do ABC - UFABC, em colaboração com o Laboratório de Habitação e Assentamentos Humanos da FAUUSP - LabHab, o GE_Favelas juntou na sua composição pesquisadores acadêmicos, profissionais em atuação ou com experiência em organismos públicos ou em escritórios privados, todos com interesse na troca de conhecimento teórico e prático sobre Urbanização de Favelas. O grupo reúne-se regularmente em encontros que têm proporcionado a apresentação e discussão de experiências acadêmicas ou práticas, desenvolvidas por integrantes ou convidados, sobre temas associados à intervenção em favelas. ${ }^{7}$

Estes dois momentos do meu percurso foram fundamentais para a elaboração de um projeto de pesquisa de mestrado sobre Urbanização de Favelass ${ }^{8}$ e o ingresso no programa de Pós-Graduação da FAUUSP, na área de HABITAT, em 2015.

Em paralelo, fui arriscando, junto com outros colegas, a prática de assessoria técnica na luta pelo direito à moradia adequada, pelo direito à cidade e, cada vez mais, na defesa da intervenção em assentamentos precários, no sentido da garantia dos direitos anteriores para a população residente. Digo arriscando pois também a prática de assessoria técnica social em arquitetura e urbanismo, não é ensinada, pelo menos não dentro das faculdades, pelo que, a nossa prática foi pautada pela experimentação e aprendizado, como por exemplo no contado com o Movimento Sem Teto - UNAS Heliópolis e Região9 e na organização da I Oficina: Favelas ${ }^{10}$.

O encontro destas oportunidades aparece na minha procura e interesse por práticas onde as técnicas da arquitetura e urbanismo e o interesse social se reúnem. Esta breve biografia poderia até ser dispensável, no entanto, este trabalho também se trata disso, de uma análise sobre biografias profissionais, como veremos em seguida.
7. Neste grupo, tive a felicidade de encontrar a minha atual orientadora, também orientadora metodológica do grupo e atual responsável pelo LabHab. A prof. Karina Leitão tem uma vasta pesquisa sobre programas habitacionais e coordena dentro da FAUUSP a pesquisa: Investigação sobre padrões precariedade habitacional e urbana e os desafios que estes colocam à urbanização de assentamentos precários em cidades brasileiras (in currículo lattes Karina Leitão).

8. A delimitação do conceito de Urbanização de Favelas como será abordado no decorrer do texto, está desenvolvido adiante.

9. A UNAS (União de Núcleos, Associações dos Moradores de Heliópolis e Região) é uma entidade sem fins lucrativos que surgin em meados dos anos I 980 a partir da organização de moradores da favela de Heliópolis que lutavam pelo direito à moradia e posse da terra. (in www.unas.org.br consultado em o8/02/2016). Em 20I 4, junto com os arquitetos, Felipe Moreira e Paloma Siqueira, propusemos uma atividade de troca de conhecimento sobre arquitetura e urbanismo para os integrantes da coordenação Movimento Sem Teto UNAS. Mensalmente, no periodo de 2015 e 2016 , foram realizados encontros onde foram abordados entre outros, os seguintes temas: expansão urbana de São Paulo, mapeamento colaborativo de Heliópolis, Programa Minha Casa Minha Vida (PMCMV)-Entidades, questões técnicas e legais sobre construção na cidade, intervenções públicas em Heliópolis - urbanização de favelas, provisão habitacional, CEU, etc. 
I o. A I Oficina: Favelas foi um evento organizado pelo LabLaje, direcionado para alunos de graduação multidisciplinares, mas aberto a técnicos, moradores, agentes públicos e privados e pesquisadores para a troca de experiências, pesquisas, práticas, dúvidas e inquietações sobre a atuação em favelas. O evento teve uma componente prática e outra teórica e foi realizado entre os dias 20 a 29 de Julho de $2016 \mathrm{em}$ São Paulo.

O LabLaje é um grupo de pós-graduando da FAUUSP, composto por Felipe Moreira, Paula Oliveira, Rodrigo Faria, Victor Iacovini, Vitor Nisida e por mim. Em comum, partilhamos o interesse por favelas, tema que abordamos nas nossas pesquisas individuais de pós-graduação, reconhecendo e compreendendo a necessidade e complexidade de intervenção desses territórios. O grupo foi formado oficialmente em Abril de 20 I 6 para a realização da I Oficina: Favelas.

I I. Para fluidez do texto, tomamos o conceito universal dos substantivos masculinos: sujeito(s), individuo(s), arquiteto(s). Neste grupo cabem também individuos, sujeitas e arquitetas do sexo feminino.

12. Jonathas Magalhães Silva, Manoel Ribeiro e Carlos Nelson Ferreira dos Santos, são 3 dos sujeitos identificados como militantes e selecionados como 'objeto de estudo' para o desenvolvimento desta pesquisa.
Nesta pesquisa, a procura por referências técnicas sobre 'saber fazer' Urbanização de Favelas foi progressivamente se transformando numa procura por referências de condutas, de posturas profissionais, onde a ação técnica se mistura com a ação política e ética. Ao longo da pesquisa, a análise a partir de etapas de desenvolvimento de processos de urbanização de favelas vai-se transformando na leitura e no cruzamento de informações a partir de relatos sobre os processos que certos indivíduos ${ }^{11}$ viveram, carregados de relações afetivas, e do reconhecimento da importância das trajetórias individuais dos entrevistados para a forma de atuar em favelas.

Esta pesquisa não pretendeu o rigor de análises qualitativas tradicionais das ciências sociais. No entanto, reconheço o meu encantamento e tentativa de aproximação de leituras mais sensíveis ao abordar os sujeitos pesquisados, buscando análises que iluminam campos objetivos e subjetivos de suas experiências profissionais em favelas. A pesquisa faz uso de técnicas da abordagem de história oral, já consolidadas no campo das ciências sociais e humanas. Como se verá, em grande medida, a fonte de informações deste projeto está concentrada na informação coletada em entrevistas, que são confrontadas a outros tipos de referências, como documentos projetuais, e a própria literatura acadêmica sobre o tema, para compreensão da questão investigativa. Ao lado das memórias narradas, da autobiografia explorada, confrontamos a interpretação dos indivíduos entrevistados ao contexto histórico de urbanização de favelas no país. $\mathrm{O}$ trabalho preparatório para a exploração dos depoimentos orais, antecede-o e se prolonga após as entrevistas, num conjunto de atividades de pesquisa complexas e, por que não dizer, muito pouco lineares. Em grande medida, visa a captação de material pouco explorado, no caso, a militância em urbanização de favelas, para a tentativa de um registro histórico e para a disseminação do conhecimento.

A aproximação ao depoimento e à autobiografia, assim com ao campo das ciências sociais foi diretamente influenciada por este percurso, e pelo próprio processo de desenvolvimento da pesquisa, inclusive por alguns dos indivíduos 'pesquisados'. Nas práticas de Jonathas Magalhães, Manoel Ribeiro e Carlos Nelson ${ }^{\mathrm{I}}$, e nas teorias 
também de Carlos Nelson e Colette Pétonnet ${ }^{13}$, encontrei a justificativa e motivação necessária para me aproximar da antropologia e de procurar testar algumas das metodologias que ela utiliza.

Estou longe de ser uma 'antropoteta' como Carlos Nelson se auto-nomeava (SANTOS, i 98 I, p. I 3), e de atuar como uma antropóloga urbana como Colette Pétonnet, mas procurei, através desta exploração, 'deixar-me levar' pelas descobertas da pesquisa, 'dando palavra' aos sujeitos entrevistados através dos seus depoimentos ou do resultado das ações que consegui acessar e analisar.

Neste 'deixar levar' a pesquisa tomou outra direção para além da primeira proposta no projeto de pesquisa, ou talvez aquela que eu sempre procurei, mas que não tinha reconhecido inicialmente.

A imparcialidade não cabe neste texto, nem nas práticas dos sujeitos selecionados, como vamos expor adiante, mas cabe ressaltar que a imparcialidade não foi aqui buscada. Não entendo nem ciência, nem técnicas como neutras, nesse sentido, deixo claro o meu engajamento e admiração pela trajetória profissional dos sujeitos pesquisados, e o reconhecimento de que suas experiências, com todas as suas contradições, merecem ser registradas e debatidas largamente.
13. Carlos Nelson vai-se identificar como 'antropoteto' (SANTOS, I $98 \mathrm{I}, \mathrm{p}$. XX) pelas práticas que exercia e reconhecia afastarem-se do modo de fazer do arquiteto, aproximando-se das do cientista social. Colette Pétonnet vai introduzir na Escola de Sociologia Francesa, em meados do século XX um olhar sobre os mais pobres em ambiente urbano, carregado pela sua experiência prática de técnica social em ambientes precários (PÉTONNET, 20 I2) Tomei contato com o trabalho de PÉTONNET na disciplina de Antropologia da Cidade, lecionada pelo prof. Heitor Frúgoli Jr., no $2^{\circ}$ semestre de 2015 , no programa pós-graduação da FFLCH USP. 


\section{INTRODUC̣̃̃̃}

Cabe iniciar este documento indicando que optamos pela utilização do conceito Favela, tal como Bueno (2000), LABHAB ( I 999), Denaldi (2003), Petrarolli (20 I 5), considerando o acúmulo histórico do conceito e entendendo que o mesmo abrange um campo de conhecimento onde são reconhecidas morfologias identificadas como conjuntos de moradias de morfologia irregular, com algum grau de insalubridade e precariedade inerentes, resultado de complexos processos de desenvolvimento urbano brasileiros. Reconhecemos na favela, diferentes morfologias de assentamento habitacional precário. No conceito aqui apresentado, incluímos também os loteamentos irregulares, carentes de alguma intervenção urbana, mas excluímos as designações de cortiço e conjunto habitacional precário, exceto nos casos em que estes se encontram integrados nos assentamentos acima designados.

Como Urbanização de Favelas toma-se uma aproximação ao conceito utilizado pelo Ministério das Cidades para urbanização de assentamentos precários, tratando-se de:

intervenções [que] buscam o estabelecimento de padrões mínimos de habitabilidade e a integração do assentamento à cidade, mediante o máximo aproveitamento dos investimentos já feitos pelos moradores, ou seja, por meio da adaptação da configuração existente, de forma a viabilizar a implantação e funcionamento das redes de infraestrutura básica, melhorar as condições de acesso e circulação, eliminar situações de risco, etc. (MCIDADES, 2010b, p.35)

Não se procura aqui reiterar a definição de programa ou política habitacional. A aproximação ao conceito 'oficial' pretende a compreensão desta atuação dentro de um campo apreensível. Ao longo da pesquisa fomos identificando diferentes nomenclaturas e nomes dados a este tipo de intervenção. Neste contexto, importa delimitar o conceito como um campo de atuação, que abrange algumas práticas de intervenção em favelas, mas elimina outras, o que é determinante para a compreensão do objeto de pesquisa que nos propomos a analisar. 
Não cabem neste âmbito, as intervenções em favelas que tomam como partido a remoção total de determinado assentamento precário para reassentamento total em novas unidades, mesmo que estas recorrentemente sejam chamadas de Urbanização de Favelas, ou a intervenção que apenas compreende a produção habitacional, mesmo que na mesma área ou adjacente à favela alvo de intervenção. Pretende-se um estudo sobre processos de escala e intervenção urbana, incluindo o projeto, compatibilização e execução de infraestruturas.

Ao longo da pesquisa, fomos identificando 'uma forma de fazer' Urbanização de Favelas, reconhecendo a contribuição e atuação política no campo da prática, da técnica e do pensamento, e entendendo a importância dos próprios indivíduos neste campo de atuação. Passamos a referir-nos a estes como sujeitos militantes, conceito que entendemos ser dotado de intenção, e transportar consigo a conotação política que nos importa destacar. ${ }^{14}$

Note-se que esta militância deve ser entendida como a atuação engajada e comprometida dentro do campo da Urbanização de Favelas. Não estamos falando de militância político-partidária. Tratamos dos sujeitos empenhados no fazer e no pensar as urbanizações, engajados em refletir permanentemente sobre a sua ação no território, mais especificamente em favelas, no ato de projetar no seu sentido mais amplo e transformador. Há diferenças entre eles e entre os processos que fizeram parte que merecem ser destacadas, no entanto, este estudo pretende relevar os pontos de debate semelhantes, os pontos comuns, que avançam para um pensamento coletivo dos militantes sobre Urbanização de Favelas.

Reconhecemos muitos deles na história das Favelas do Brasil, alguns mais notórios, outros quase anônimos, arquitetos, engenheiros, trabalhadores do serviço social, funcionários públicos, advogados, geógrafos, antropólogos, psicólogos, também moradores, lideranças comunitárias, etc. Interessava-nos aqui, no entanto, olhar para a militância no campo da arquitetura e do urbanismo, mais especificamente no campo da urbanização de favelas. E dentro dela, focar em trajetórias profissionais em que a ação projetual, a experimentação em obra e a preocupação com a formação de futuros arquitetos, estivesse presente no repertório desses sujeitos militantes.
I 4. O conceito militante como aqui utilizamos será desenvolvido no Cap. I. 
15. Compreendemos, no entanto, as especificidades sócio-territoriais de cada região do país e de que estas regiões não abrangem a totalidade da heterogeneidade presentes. Mas assumimos a relevância destas regiões e suas experiências no campo da Urbanização de Favelas, para além da necessidade da delimitação espaço-temporal do objeto estudado.
Esta pesquisa partiu da procura por referências projetuais de Urbanização de Favelas e da tentativa de compreensão de metodologias para o exercício do arquiteto e urbanista. Propúnhamos um entendimento e uma reflexão sobre a influência das condicionantes externas (programas, políticas públicas, contratos, legislação, etc.) e internas (conhecimento técnico dos indivíduos, relações com a comunidade moradora, a própria a comunidade moradora, etc.) na escolha de determinadas metodologias, que por fim, resultariam em determinadas decisões do projeto proposto e da obra executada.

Para tal, decidimos selecionar alguns indivíduos com experiência prática em projeto de Urbanização de Favelas, e em obra, com mais de 10 anos de experiência. A ideia inicial foi de estabelecer uma comparação entre dois casos projetuais para cada sujeito entrevistado, selecionados pelo próprio arquiteto, um mais antigo e um mais recente na sua experimentação em Urbanização de Favelas para, na comparação entre os casos, compreender as motivações, condicionantes, adaptações, transformações e opiniões sobre os processos e seus resultados. Este panorama possibilitaria uma reflexão sobre o conhecimento acumulado em Urbanização de Favelas, e sobre a situação atual dos arquitetos projetistas perante a Urbanização. A importância da seleção de indivíduos com vasta experiência em Urbanização de Favelas partiu da premissa da compreensão temporal alargada, para o entendimento da transformação dos processos ao longo do tempo.

Como recorte territorial, focamos em experiências desenvolvidas na Região Metropolitana de São Paulo (RMSP) e do município do Rio de Janeiro. A seleção das atuações nas duas áreas da região sudeste do país, serve como representatividade chave e como exemplos de experiências referência da restante realidade urbana do Brasil ${ }^{15}$.

Englobou-se, com os sujeitos selecionados, e os casos que estes participaram, um período que remete a uma das primeiras experiências datada de urbanização de favela no país, Brás de Pina, nas décadas de $60 / 70$, passando pelo programa municipal pioneiro Favela-Bairro, anos 90/2000, até às experiências dentro do Programa de 


\begin{tabular}{|c|c|c|c|c|}
\hline LOCALIZAÇÃO & $\begin{array}{l}\text { PROCESSO DE } \\
\text { URBANIZAÇÃO DE } \\
\text { FAVELAS }\end{array}$ & DATA & $\begin{array}{l}\text { PROJETISTAS } \\
\text { [OU GESTORES] }\end{array}$ & $\begin{array}{l}\text { SUJEITO } \\
\text { PESQUISADO }\end{array}$ \\
\hline \multirow{9}{*}{ RIO DE JANEIRO } & BRÁS DE PINA & $1969-1973$ & QUADRA ARQUITETOS & CARLOS NELSON F. SANTOS \\
\hline & SERRINHA & $1996-2001$ & & MANOEL RIBEIRO \\
\hline & \multirow{4}{*}{$\begin{array}{l}\text { PAVÃO-PAVÃOZINHO E } \\
\text { CANTAGALO }\end{array}$} & \multirow{4}{*}{ 1999-2003 } & \multirow{4}{*}{$\begin{array}{l}\text { CONSÓRCIO COBRAPE / } \\
\text { MAYERHOFFER \& TOLEDO } \\
+ \text { MPS ASSOCIADOS }\end{array}$} & JONATHAS SILVA \\
\hline & & & & VERA TÂNGARI \\
\hline & & & & MANOEL RIBEIRO \\
\hline & & & & LUIZ CARLOS TOLEDO \\
\hline & \multirow{3}{*}{$\begin{array}{l}\text { PLANO SOCIO-ESPACIAL } \\
\text { DA ROCINHA }\end{array}$} & \multirow{3}{*}{$2007-2008$} & \multirow{3}{*}{ MAYERHOFFER \& TOLEDO } & JONATHAS SILVA \\
\hline & & & & VERA TÂNGARI \\
\hline & & & & LUIZ CALROS TOLEDO \\
\hline \multirow{11}{*}{ RMSP } & $\begin{array}{l}\text { PROGRAMA DE URB. DE } \\
\text { FAVELAS DE DIADEMA }\end{array}$ & $1983-1996$ & [PM DIADEMA] & MILTON NAKAMURA \\
\hline & VILA POPULAR & $1994-1995$ & USINA CTAH & WAGNER GERMANO \\
\hline & TAMARUTACA & $2000-2003$ & PEABIRU TCA & CAIO SANTO AMORE \\
\hline & JARDIM SILVIO SAMPAIO & $2006-2009$ & [PM TABOÃO DA SERRA] & HELOISA REZENDE \\
\hline & \multirow{2}{*}{ JARDIM SANTO ONOFRE } & \multirow{2}{*}{ 2007-2009 } & \multirow{2}{*}{$\begin{array}{l}\text { "BND ARQUITETOS [PM } \\
\text { TABOÃO DA SERRA]" }\end{array}$} & HELOISA REZENDE \\
\hline & & & & MILTON NAKAMURA \\
\hline & \multirow{2}{*}{ CAPELINHA } & \multirow{2}{*}{ 2011-2015 } & \multirow{2}{*}{ PEABIRU TCA } & CAIO SANTO AMORE \\
\hline & & & & ALEXANDRE MARQUES \\
\hline & \multirow{2}{*}{ BATISTINI } & \multirow{2}{*}{ 2011-2016 } & \multirow{2}{*}{ PEABIRU TCA } & CAIO SANTO AMORE \\
\hline & & & & ALEXANDRE MARQUES \\
\hline & COMPLEXO CHAFIK & $2013-$ & $\begin{array}{l}\text { "TEREZA ARQUITETURA } \\
\text { [PM MAUA]" }\end{array}$ & MILTON NAKAMURA \\
\hline
\end{tabular}

tab 1. Casos de estudo. Apresentação dos sujeitos pesquisados a partir dos processos de urbanização de favelas. Fonte: própria.
Aceleração do Crescimento - PAC, estendendo a análise ao programa Morar Carioca, todos eles localizados na cidade do Rio de Janeiro. $\mathrm{Na}$ RMSP, abrangemos as experiências pioneiras na região, nas prefeituras de Diadema, Taboão da Serra, Santo André e São Bernardo do Campo, dos anos 80/90, chegando às experiências desenvolvidas dentro do PAC UAP (Programa de Aceleração do Crescimento, modalidade Urbanização de Assentamentos Precários, nos governos Lula e Dilma - 2003 a 20 I 5 ).

$\mathrm{Na}$ seleção sobre os sujeitos a pesquisar, procuramos aqueles que tinham vasta experiência temporal em Urbanização de Favelas, mas ao mesmo tempo, aqueles que em sua forma de atuação identificávamos um engajamento social, quase político, de práticas, soluções e propostas que aparentavam maior preocupação e proximidade com as realidades dos seus interlocutores, os moradores das favelas. Procurávamos os projetistas que viviam 'na e a favela' durante o desenvolvimento de projeto, reconhecendo e se importando com suas características físicas e sociais. Aqueles que muitas vezes, ultrapassavam as limitações legais e burocráticas exigidas ou definidas por contrato, e propunham soluções alternativas ou menos comuns, para melhor se adequarem ao seu local e seus usuários. Procurávamos os indivíduos que na sua prática buscam intervir em favelas "sem legitimar a precariedade do lugar mas sem serem colonizadores” nas suas formas de atuação (LEITÃO, 20 I 6, informação verbal) $)^{16}$.

Considerando que este quadro de arquitetos militantes inicia-se num marco referencial histórico, a atuação dos Quadra Arquitetos, mais especificamente a atuação do arq. Carlos Nelson Ferreira dos Santos, em Brás de Pina, no Rio de Janeiro, nos anos 70, recuamos até essa experiência tomando-a como parte do quadro montado. Aos restantes arquitetos
16. Caracterização dos técnicos militantes a sua forma de atuar em favelas feita pela prof. Karina Leitão, durante a sua apresentação oral na I Oficina: Favelas, organizada pelo LabLaje em 2016 (ver nota 10).

17. Esta rede parte do GE_Favelas, da rede LabHab FAUUSP e das indicações entre os próprios sujeitos entrevistados. 
escolhidos, chegamos através de pesquisa bibliográfica e empírica, pela rede de contatos ${ }^{17}$ com atuação em Urbanização de Favelas.

Não pretendemos com a seleção destes I 0 sujeitos ( 5 de atuação em favelas no Rio de Janeiro, 5 na RMSP) restringir o campo ou a definição de arquitetos militantes. Não pretendemos também, através desta análise, apresentar uma cartilha de etiqueta e práticas a serem seguidas, para alguém que queira tomar o caminho da prática projetista militante. Buscamos uma reflexão sobre este campo de atuação e conhecimento que nos interessa, a partir da exploração de determinados casos, que identificamos terem pontos comuns na intervenção em favelas. Os sujeitos e os processos selecionados destacam-se em algum aspeto do seu contexto político e programático, indo, na maioria dos casos, no sentido oposto ao que se estabeleceu na sua época como intervenção em favelas.

Mesmo encontrando alguns destes sujeitos atuando fora do âmbito dos programas do poder público, em atividades de extensão universitária, assessoria técnica ou ativismo político declarado, os casos projetuais que aqui abordamos tratam-se de experiências promovidas pelo poder público. Os casos nem sempre estão inseridos em contextos de gestões progressistas. No entanto, importa-nos um olhar direcionado para estas experiências promovidas pelo poder público pois reconhecemos nelas a viabilização efetiva da transformação do território na grande escala, pelo menos nos casos desenvolvidos até então no Brasil. Adiante avançaremos sobre algumas das limitações dentro deste contexto de atuação.

Apesar das condicionantes, encontramos neste recorte a abertura possível (e para alguns deles, ideal) no campo de trabalho dos sujeitos militantes em favelas. Importa-nos olhar para, como dentro dos limites colocados, a prática se mantém (ou não) militante, mesmo que em contexto menos favoráveis.

Se, inicialmente, demos preferência para arquitetos com atuação estritamente projetista em Urbanização de Favelas, fomos compreendendo que os sujeitos de atuação militante, assumem nos seus percursos outros papéis, como o da gestão pública, e acabamos por alargar os casos de estudo a alguns sujeitos com históricos em gestão, 
para lá apenas do ato de projetar, ou onde esses papéis se misturam, como é o caso de Milton Nakamura em prefeituras do ABC Paulista, ou Heloisa Rezende em governos municipais da RMSP. Esse alargamento levou-nos à compreensão de que o sujeito militante em Urbanização de Favelas, é militante em qualquer campo de atuação, mesmo dentro das limitações já referidas e abordadas ao longo deste texto (PULHEZ, 20 I 6, informação verbal) ${ }^{18}$.

Sabíamos que a procura por referências em Urbanização de Favelas ultrapassava as representações gráficas usualmente utilizadas para ilustração, análise e avaliação de projetos de arquitetura e urbanismo. Na Urbanização de Favelas como aqui é colocada, o arquiteto toma o papel de compatibilizador das diferentes disciplinas e redes, assim como, algumas vezes, o de mediador entre diálogos. As propostas de Urbanização de Favelas dão-se também nos acordos realizados entre população, poder público, todos os técnicos projetistas e eventualmente outros agentes. Para encontrar estes dados e informações quase imateriais elegemos a entrevista como a ferramenta base da pesquisa. Apenas a análise do arquiteto Carlos Nelson ${ }^{19}$ seria realizada apenas a partir do levantamento bibliográfico ${ }^{2 \circ}$.

Todas as entrevistas foram realizadas apenas por mim, grande parte delas no período compreendido entre Novembro e Dezembro de 2015 , às quais acrescentamos os depoimentos das arquitetas Heloísa Rezende e Vera Tângari realizadas entre Outubro e Novembro de 20 I6. A integração posterior surgiu da importância de incluir a perspectiva de mulheres projetistas militantes protagonistas nesta pesquisa dentro do quadro de seleção de sujeitos, apesar de já considerarmos que as equipes projetistas da grande parte dos casos descritos tinham na sua composição elementos do sexo feminino. Em nenhum momento, foi considerada uma limitação de gênero em relação a sujeitos que considerávamos militantes. Para além da contribuição para a análise, a integração das entrevistas às arquitetas Heloísa Rezende e Vera Tângari, pretende reforçar a indiscriminação de gênero sobre os arquitetos projetistas militantes reconhecendo o papel das mulheres neste campo de atuação.
18. Constatação realizada por Magaly Pulhez na sua apresentação em um dos encontros do GE_FAVELAS realizado em 26/09/2016. Magaly é arquiteta e urbanista com pesquisa aprofundada sobre urbanização de favelas. Nos temas de sua pesquisa contam: projetos de Urbanização de Favelas desenvolvidas por Assessorias Técnicas (2007), processos participativos (2008a, 2008b), e o papel das gerenciadoras em Urbanização de Favelas (20 I 4).

I 9. O arquiteto Carlos Nelson faleceu em 1989. Apesar do seu falecimento ainda jovem, foi protagonista de uma atuação profissional e produção acadêmica intensa, e que é referência no campo da atuação militante e em favelas. No II UrbFavelas Seminário Nacional sobre Urbanização de Favelas, realizado em 20 I 6 no Rio de Janeiro, o arquiteto foi homenageado com a composição de uma mesa dedicada à sua trajetória profissional.

20. Tanto Luiz Carlos Toledo como Manoel Ribeiro conheceram pessoalmente Carlos Nelson, e os seus depoimentos contribuem para o esclarecimento sobre este sujeito. Nas suas falas aparece a importância e influência da figura de Carlos Nelson quer para cada um deles individualmente, como para o campo de conhecimento sobre a intervenção em favelas, pelo menos no Rio de Janeiro. 
21. A menor gravação tem duração de Ihe 20 min e a maior 2 he 3 omin.

22. Na época ainda não era claro que o foco da pesquisa eram os militantes e não apenas as suas experiências profissionais em favelas.
As entrevistas foram semi-orientadas. O guião foi previamente encaminhado para o entrevistado conhecer o teor do que se pretendia na conversa. As entrevistas foram realizadas nos locais escolhidos pelos próprios sujeitos, em seus escritórios ou em suas moradias e foram gravadas para consulta posterior. Optou-se pela não transcrição integral das entrevistas neste documento, utilizando apenas algumas transcrições parciais que serão introduzidas ao longo do texto como ilustração das reflexões apresentadas. Apesar da orientação previamente encaminhada, as entrevistas transformaram-se em longas conversas ${ }^{21}$ sobre a temática da urbanização de favelas, conduzidas pelos pontos sugeridos e com base nas práticas, nas opiniões e nas reflexões pessoais dos sujeitos entrevistados.

$\mathrm{Na}$ primeira entrevista, realizada ao arq. Jonathas Magalhães Silva, ele pediu-me para que fizesse uma breve apresentação minha e da minha pesquisa. Senti necessidade de partilhar um pouco do meu percurso profissional e pessoal, das minhas inquietudes face ao tema, da busca que tal tinha originado, assim como a explicação da sua integração naquela seleção $0^{22}$. Esta partilha permitiu o estabelecimento de tom de conversa informal, originando no meu interlocutor, talvez, alguma a sensibilização pelo meu percurso ou a identificação pela motivação da minha pesquisa, e permitindo que este partilhasse, para além das suas experiências, as suas opiniões e reflexões sobre o assunto. A partir de então, procurei iniciar todas as entrevistas com a minha apresentação, procurando encontrar no registro informal, o acesso a informações que são menos públicas e mais pessoais, mas que ainda assim, reconhecemos fazerem parte da formação dos sujeitos e por isso têm reflexão direta nas suas formas de atuação.

Na proposta inicial pedíamos, para além da seleção de duas experiências de Urbanização de Favelas que haviam participado em tempos distintos, uma análise dos casos a partir do que definíamos como etapas da Urbanização de Favelas: diagnóstico, projeto e obra.

Foi a partir do conjunto das entrevistas que compreendemos a inadequação desta proposta de análise. Para estes sujeitos, a sepa- 
ração em etapas em Urbanização de Favelas não é adaptada às suas formas de atuação. Estes sujeitos sabem que ao território da favela é inerente um constante processo de transformação, onde os levantamentos base são, habitualmente, pouco fidedignos ou válidos por um período limitado de tempo, onde o projeto tem que ser adaptado às informações que vão surgindo no processo de aproximação, e revisado, muitas vezes por completo, no momento da obra.

Verificamos que os sujeitos entrevistados, mesmo se adaptando às exigências de programas oficiais, com documentos representativos das etapas: diagnóstico, projeto e obra, desenvolviam, no seu processo de atuação, ações, técnicas, métodos e opiniões que entremeavam e cruzavam as relações entre as 'caixas' pré-definidas de etapas de Urbanização de Favelas.

Encontramos nas ações e reflexões dos sujeitos, mesmo que em contextos completamente distintos, ponto de contato, possibilitando o agrupamento em práticas que chamamos também de militantes. ${ }^{23}$ Mantivemos ainda o olhar para os casos selecionados pelos próprios sujeitos, como representativos da forma de atuação dos mesmo em Urbanização de Favelas. Estes serão apresentados adiante mais pormenorizadamente pelos pontos que consideramos representativos.

Desta forma, a pesquisa deixou de ser focada n'O Processo Metodológico de Urbanização de Assentamentos Precários: um estudo a partir da relação Levantamento-Projeto-Obra EM EXPERIÊNCIAS no Rio de Janeiro e em São Paulo ${ }^{24}$ para passar a olhar para os sujeitos militantes e suas práticas como objeto de estudo e análise.

Para completar a pesquisa e coleta de dados, recorremos ao levantamento de informações gráficas e bibliográficas, sobre os casos selecionados pelos sujeitos entrevistados, assim como às comunicações públicas assistidas por mim pessoalmente, ou registadas em áudio ou vídeo.

Em alguns casos, houve a necessidade de visita aos locais dos casos de estudo, na Região Metropolitana da São Paulo e no Rio de Janeiro, principalmente para entendimento das dimensões relatadas pelos sujeitos. As visitas realizadas tomaram o papel mais de contextualização do que análise dos processos e projetos realizados.

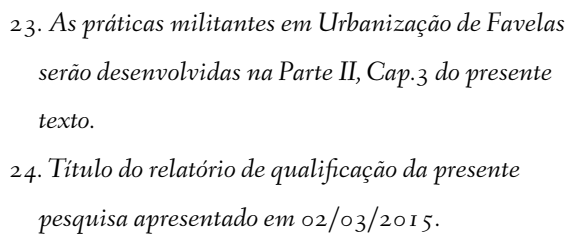


A grande parte da documentação gráfica deste produto, original ou trabalhada, foi gentilmente cedida pelos sujeitos entrevistados. A grande parte disponibilizou-me o acesso irrestrito aos seus materiais de trabalho: desenhos e documento de desenvolvimento, fotografias, produtos finais, apresentações e documentos oficiais. A seleção das imagens utilizadas ficou, no entanto, sob minha responsabilidade para ilustração das reflexões desenvolvidas na pesquisa que segue organizada da seguinte forma.

A Parte Um está dividida em dois capítulos e é dedicada à introdução dos casos de estudo: os sujeitos e os processos de Urbanização de Favelas selecionados.

No Capítulo i, exploramos o conceito de Arquitetos Militantes em Urbanização de Favelas como aqui nos propomos abordar, recorrento aos conceitos de EsTÉTICA, TÉCNICA E ÉTICA nas práticas dos arquitetos e urbanistas neste campo de atuação. Apresentamos ainda os Currículos dos sujeitos selecionados, com um enfoque para a atuação destes em e com favelas.

O Capítulo 2 explora a contextualização dos processos de Urbanização de Favelas selecionados, introduzindo-os nA LINHA DO tempo da Urbanização de Favelas no Brasil procurando explorar em que medida cada um, através do protagonismo dos sujeitos, tratou-se de um caso de militância no seu tempo, no seu lugar e dentro das suas condicionantes. Este capítulo será entermeado pela apresentação de cada um dos processos de Urbanização de Favelas, olhados de perto para o desenvolvimento desta pesquisa, através de desenhos resumo de levantamento ou diagnóstico e projeto urbanístico.

A Parte dois, com o Capítulo 3, trata da análise das Práticas Militantes em Urbanização de Favelas, feita a partir da leitura sobre os depoimentos e demais materiais recolhidos, procurando a formulação, ou pelo menos, a organização do que considerarmos tratar-se de um acúmulo de conhecimento gerado a partir das práticas de atuação de sujeitos militantes em urbanização de favelas. Este capítulo encontra-se ilustrado a partir das falas e das imagens, fotografias, desenhos, esquemas, utilizados pelos sujeitos no desenvolvimento dos seus processos. 
Por fim, partindo do agrupamento das reflexões de cada um dos sujeitos, e das nossas próprias neste processo de pesquisa, avançamos, na Parte três, nas Notas Conclusivas, para um ensaio sobre o espaço destinado ao sujeito: arquiteto militante na Urbanização de Favelas no contexto atual e num futuro próximo. 
:
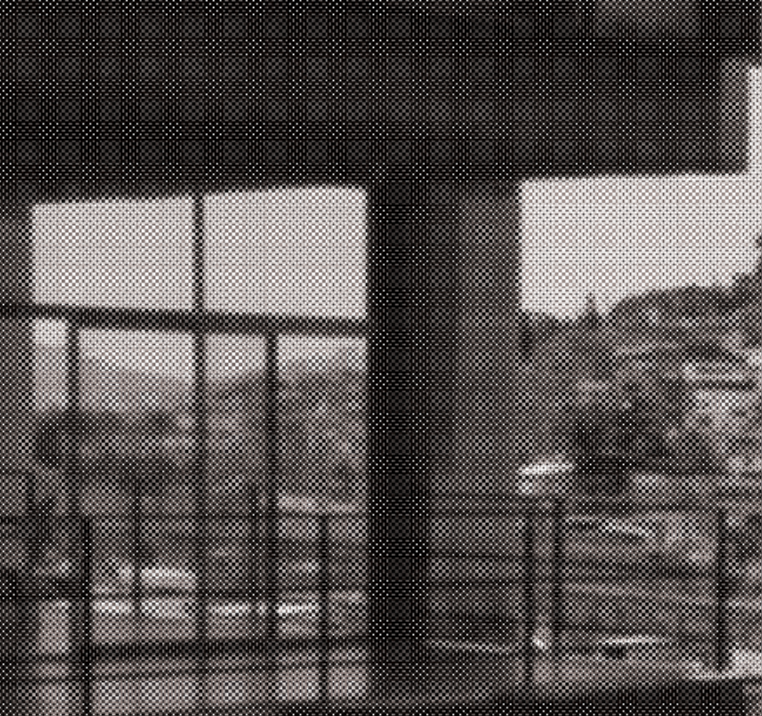

m

1) $1{ }^{2}=$ 19:

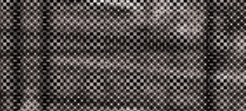
$4=\frac{1}{2}$
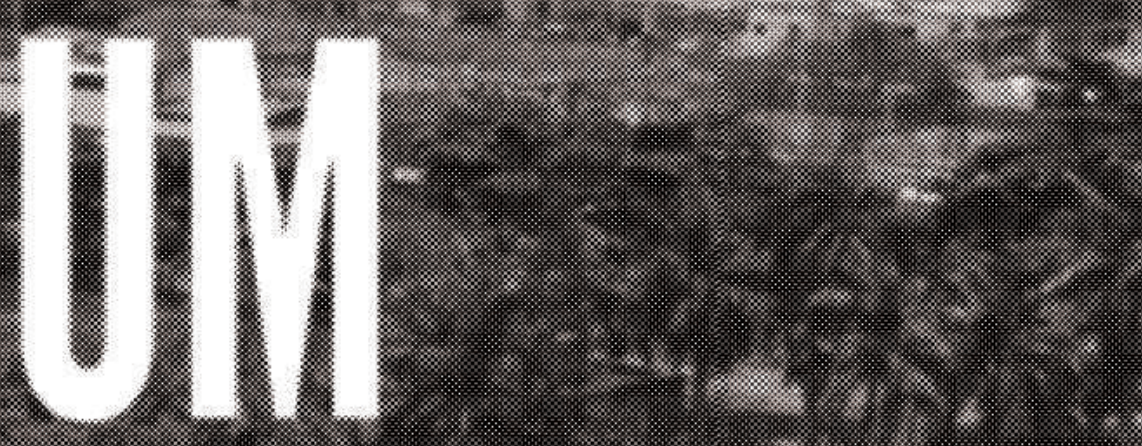

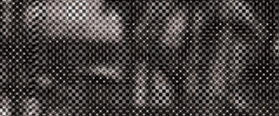

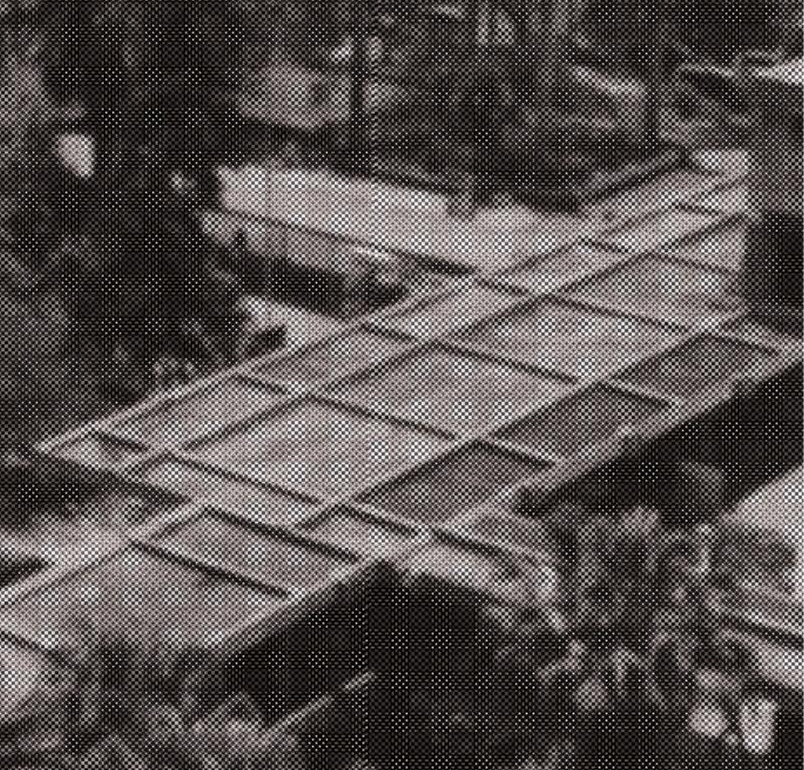



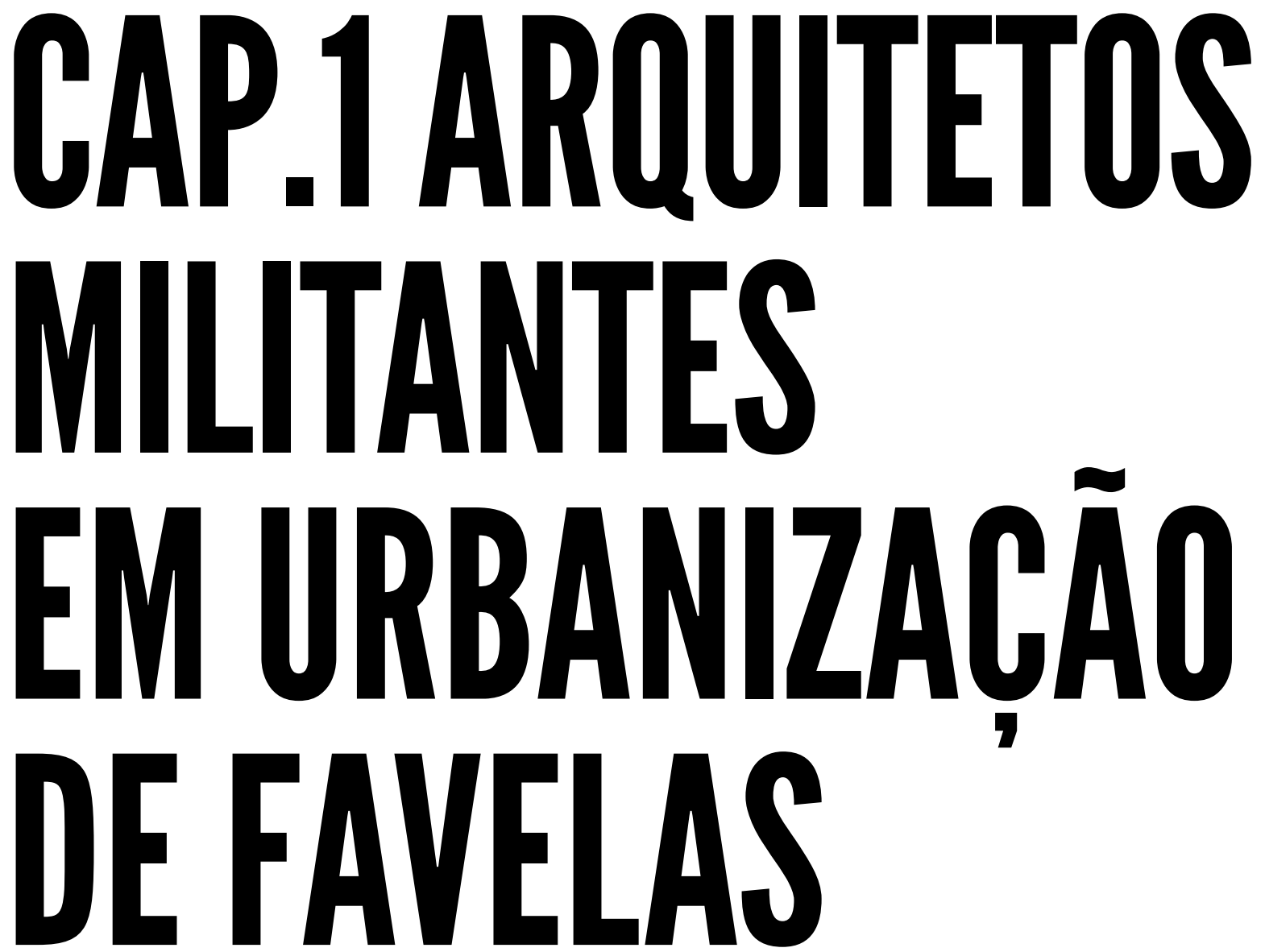

\section{UM TENSIONAMENTO ENTRE ESTÉTICA, TÉCNICA E ÉTICA}

Os arquitetos e urbanistas militantes em urbanização de favelas são os sujeitos centrais na investigação aqui apresentada. É a partir de sua trajetória, das informações verbais por eles concedidas e dos documentos de trabalho por eles apresentados que a pesquisa se desenvolve e se estrutura.

Nesse sentido, cabe neste primeiro capítulo apresentar o nosso objeto de estudo: os arquitetos militantes selecionados no âmbito desta pesquisa, e tecer algumas considerações sobre aquilo que está sendo designado como prática militante e suas nuances neste trabalho.

Propusemo-nos encontrar sujeitos com atuação prática como arquitetos em Urbanização de Favelas que, mesmo atuando na contradição, confrontaram o sistema e as condições que lhes foram impostas. Alguns publicizam pouco o seu trabalho contudo, são referências de reflexão crítica e prática nos seus campos de atuação. Alguns foram contribuindo, através da produção escrita, para a bibliografia sobre o assunto. Outros estão apenas relacionados com as favelas na atuação prática. Mas todos têm uma contribuição profundamente embasada no conhecimento empírico sobre a atuação do arquiteto em favelas. Nem sempre as suas reflexões concordam entre si. Num ou noutro caso, o sujeito admite ${ }^{\mathrm{I}}$ a mudança do seu próprio pensamento face às experiências que lhe são colocadas.

Partimos das experiências individuais de sujeitos-chave como Jonathas Magalhães Silva, arquiteto formado na FAUUSP, professor na FAU PUCCAMP e com vasta experiência em projetos públicos pelo seu 


\author{
I. Nas entrevista vão \\ aparecer reflexões sobre \\ as atuações individuais \\ ao longo do tempo e \\ reconhecimentos, por \\ vezes críticos, a partir \\ do acúmulo do conheci- \\ mento empírico. \\ 2. MOUIMENTOS URBANOS \\ NO RIO DE JANEIRO \\ (I98I) é uma retro- \\ spectiva sobre o seu \\ envolvimento como \\ assessor e técnico de 3 \\ movimentos urbanos \\ sociais do Rio de \\ Janeiro, onde Santos re- \\ lata e reflete sobre a sua \\ atuação como técnico e \\ sujeito politico. A sua \\ experiência profissional \\ prática vai embasar as \\ suas, produções teóricas \\ até ao final da sua vida.
}

escritório MPS Arquitetos. A sua atuação em favelas concentra-se sobretudo no Rio de Janeiro, em experiências como o Favela -Bairro, o Plano Sócio-Espacial da Rocinha e a participação no Morar Carioca. A partir de Jonathas Silva chegamos nos restantes sujeitos de atuação em favelas cariocas: Vera Tângari, Luiz Carlos Toledo, Manoel Ribeiro e Carlos Nelson F. dos Santos.

Vera Tângari foi colega de pós-graduação de Jonathas e partilha com ele a colaboração no seu escritório, e em muitos dos projetos desenvolvidos. Fez parte das atuações em favelas acima mencionadas. Mas a sua atuação em favelas inicia-se na sua recém formação em Petropólis e se prolonga para o ensino onde atualmente é professora na FAU UFRJ. Para além da colaboração com trabalhos com Jonathas, tem colaborado em trabalhos com o escritório de Luiz Carlos Toledo desde os anos 90.

Luiz Carlos Toledo apoiou largamente a atuação no Favela-Bairro de Vera e Jonathas, "abrigando" a sua equipe no espaço do seu escritório no Rio de Janeiro. Apesar do seu envolvimento meramente burocrático naquela experiência, mobilizou e incentivou a participação de Jonathas e Vera no Plano Sócio-Espacial da Rocinha. O seu "envolvimento" com favelas começa na sua infância, com as brincadeiras e amigos que convivia na favela vizinha à sua casa, e se prolongam pela sua juventude em uma outra ação de assessoria técnico-social, de apoio a um padre da favela Cerro-Corá e mais tarde, no seu primeiro projeto para a Rocinha, ainda antes do Concurso Público que ganhou para o desenvolvimento do Plano Sócio-Espacial da Rocinha.

Manoel Ribeiro aparece, para os anteriores, como um especialista sobre favelas. Com um envolvimento ativo em projetos e programas sociais, é inclusive um dos participantes do enredo de Zuenir Ventura em Cidade Partida ( I 994), sendo um dos atores na promoção da paz entre as favelas de Parada de Lucas e Vigário Geral após a Chacina de Vigário Geral em I 993. Foi um dos primeiros arquitetos a ser contratado pelo programa Favela-Bairro, e colaborou com Jonathas e Vera nos projetos de Cantagalo e Pavão-Pavãozinho por indicação de Luiz Carlos Toledo que já o conhecia. Participou no concurso para o Plano Sócio-Espacial da Rocinha, ficando a sua proposta em $2^{\circ}$ lugar.

Carlos Nelson Ferreira dos Santos é um personagem incontornável na atuação de arquitetos militantes em favelas. Lembrado como referência nos depoimentos dos anteriores, contribuiu e contribui para a produção prática e teórica sobre favelas, urbanização, planejamento e também para a antropologia urbana. Carlos Nelson faleceu em I 989 mas o seu legado registado nas suas produções bibliográficas (algumas delas biográficas ${ }^{2}$ ), assim como naqueles que partilharam com ele espaços de trabalho, permitem-nos a reflexão sobre a sua atuação e as suas práticas em Brás de Pina, 
uma das primeiras experiências públicas de Urbanização de Favelas no Brasil. Tanto Luiz Carlos Toledo, como Manoel Ribeiro, conviveram pessoalmente com Carlos Nelson e os seus depoimentos permitiram-nos também a construção do personagem sujeito militante no âmbito desta pesquisa.

Em São Paulo começamos por direcionar o nosso olhar para as assessorias técnicas, reconhecidas pelo modo "diferente" de fazer arquitetura, que tensiona e assume esse tensionamento entre a técnica e a prática política. Entendemos (e eles também se entendem) os dois casos pesquisados - a Peabiru TCA e a Usina CTAH (doravante Peabiru e Usina) - como sujeitos coletivos. Compreendemos assim que o acúmulo de experiência, conhecimento e reflexões estão no grupo e não apenas nos sujeitos individuais. A abordagem foi, no entanto, semelhante aos demais sujeitos apresentados. Entrevistamos alguns sujeitos que dentro das assessorias técnicas, tiveram participação em experiências de Urbanização de Favelas, mas procuramos reconstruir o percurso do sujeito coletivo, e a partir dele as contribuições de determinados indivíduos.

$\mathrm{Na}$ Peabiru entrevistamos Caio Santo Amore um dos integrantes mais antigos da assessoria. Participou ativamente na urbanização da favela Tamarutaca em Santo André, uma das primeiras urbanizações realizadas pela Peabiru, e desde a sua integração na assessoria manteve-se ativo nos projetos desenvolvidos. Nos recentes processos de Urbanização de Favelas do Capelinha e Batistini em São Bernardo do Campo, teve uma atuação mais afastada, participando das discussões e reflexões durante o desenvolvimento do processo no grupo. A sua "relação" com a favela, começa ainda na faculdade com uma pesquisa acadêmica e experiência levada para a Peabiru na favela Heliópolis em São Paulo.

Alexandre Hoddapp Marques é arquiteto formado pela FAUUSP e também integrante da Peabiru desde 2007. Conheceu Caio numa experiência conjunta de trabalho pela empresa Diagonal, em planejamento urbano. Antes da sua integração na Peabiru tinha participado do governo municipal de Marta Suplicy, na COHAB-SP, com projetos de moradia social. Pela Peabiru foi um dos integrantes com grande participação dos processos Capelinha e Batistini, usados como estudo de caso para esta pesquisa.

A Usina conta no seu repertório com alumas experiências em processos de urbanização de favelas. Dedicando-se sobretudo à assessoria de movimentos sociais organizados no campo da produção habitacional. Desenvolve, para além de metodologias e processos alternativos de construção, com base na procura pelo trabalho igualitário emancipado de todos os seus participantes, alguns processos de politização e organização política no sentido da luta por moradia e direito à cidade. Conta no seu currículo, com diversas 
experiências de produção de edifícios de Habitação Social, alguns processos de planejamento urbano, que chegam a atingir a escala de planos diretores municipais. A atuação em processos de urbanização de favelas enquadra-se no período de construção de emancipação democrática das gestões públicas, protagonizando projetos de urbanização de favelas em Diadema e Belo Horizonte no começo dos anos 90.

$\mathrm{Na}$ Usina, entrevistamos Wagner Germano, um dos membros fundadores e participante ativo no processo Urbanização da Vila Popular em Diadema. Para além da Usina, Wagner teve algumas ausências da assessoria para atuar em outros projetos, como nas gestões públicas municipais de São Paulo Marta Suplicy, onde pode acompanhar e desenvolver a intervenção na favela Parque do Gato, e na gestão Fernando Haddad, participando da CohabSP e do desenvolvimento do projeto de locação social.

Em São Paulo, alargamos ainda a nossa pesquisa a dois projetistas, arquitetos que tiveram experiências fundamentais na gestão pública em urbanização de favelas.

Heloísa Rezende é arquiteta formada pela FAUUSP e iniciou a sua atuação profissional dentro da Usina. Reconhecemos nela a formação política da assessoria que ela leva para as atuações em favelas dentro de gestões municipais ou como consultora. Heloísa participou da gestão municipal de
Taboão da Serra no período de 2006-20 I I, participando como projetista e gestora de processos de urbanização de favelas como Sílvio Sampaio e Jardim Santo Onofre, casos da nossa pesquisa.

Apresentamos Milton Nakamura como um sujeito envolvido com a Urbanização de Favelas desde as primeiras experiências nas gestões municipais progressistas nos anos 80. Para além de Diadema, participou em experiências de Urbanização de Favelas nas gestões municipais de São Bernardo do Campo, Mauá e São Paulo. A sua atuação como gestor e técnico público foi permeada por atuações no escritório de arquitetura do qual é sócio-fundador - Barossi Nakamura Dedecca Arquitetos Ltda. Pelo escritório pode desenvolver alguns projetos em favelas, inclusive o projeto de Urbanização do Jardim Santo Onofre em Taboão da Serra. Para além desse caso, usamos como referência de análise, o processo Chafik-Macuco, em Mauá, do qual Milton Nakamura participou como gestor e que ainda continua em processo de concretização.

Para a compreensão e conhecimento destes sujeitos, aqui brevemente apresentados, em seus contextos - suas experiências e formação - propomos uma apresentação mais detalhada a partir dos seus currículos com um foco sobre as experiências individuais com favelas.

Para tal apresentamos os currículos individuais selecionados e editados pelas autoras. Utilizamos para a sua concepção os 
currículos lattes, disponíveis na Plataforma Lattes $^{3}$ quando estes existiam, publicações ou outras informações públicas com o cruzamento da informação oral. Depois de uma primeira edição, pedimos a confirmação de cada uma das listas de experiências a cada um dos entrevistado, os quais o fizeram corrigindo e adicionando informações quando acharam pertinentes. Apresentamos por fim um sumário das experiências destes sujeitos, com uma especial atenção sobre o envolvimento com e em favelas e demais experiências que nos pareceram relevantes.

Sabemos que por se tratarem de informações, a maioria delas, oficiais - experiências profissionais e acadêmicas - não comportam toda a dimensão de formação de arquiteto e de militante enquanto sujeito político. No entanto, parece-nos importante partilhar tanto as experiências destes sujeitos, contextualizando-as no seu percurso individual quanto iluminar algumas possibilidades para a construção deste mesmo sujeito político.

Importa adiantar algumas considerações sobre o conjunto de currículos que vamos ver em seguida. São arquitetos com formação originária, na sua maioria, de faculdades públicas, a maioria também com formação em pós-graduação, o que não limita as sua relações com o ensino. Todos são sujeitos referências nas áreas de intervenção em favelas e HIS, e através de meios formais ou informais, estão envolvidos com a formação.
Encontramos, nas suas experiências, um caratér maioritariamente público, em processos onde o sujeito assume o papel de gestor ou como projetista contratado.

Se as experiências destes currículos demonstram muitos pontos semelhantes entre si, mas não podemos deixar de destacar a heterogeneidade de gerações, que se inicia com sujeitos nascidos na década de 40, até sujeitos da década de 70. Todos (com excepção de Carlos Nelson) se mantém ativos na sua atividade profissional, reforcando o caratér datado dos currículos aqui apresentados, mas que representa $o$ acúmulo de experiência e demonstram ainda o seu potencial de contribuição futura para o conhecimento sobre intervenção em favelas.

\author{
3. Site LATTES \\ disponivel em http:// \\ lattes.cnpq.br/, acesso \\ em I3/02/I 7 .
}



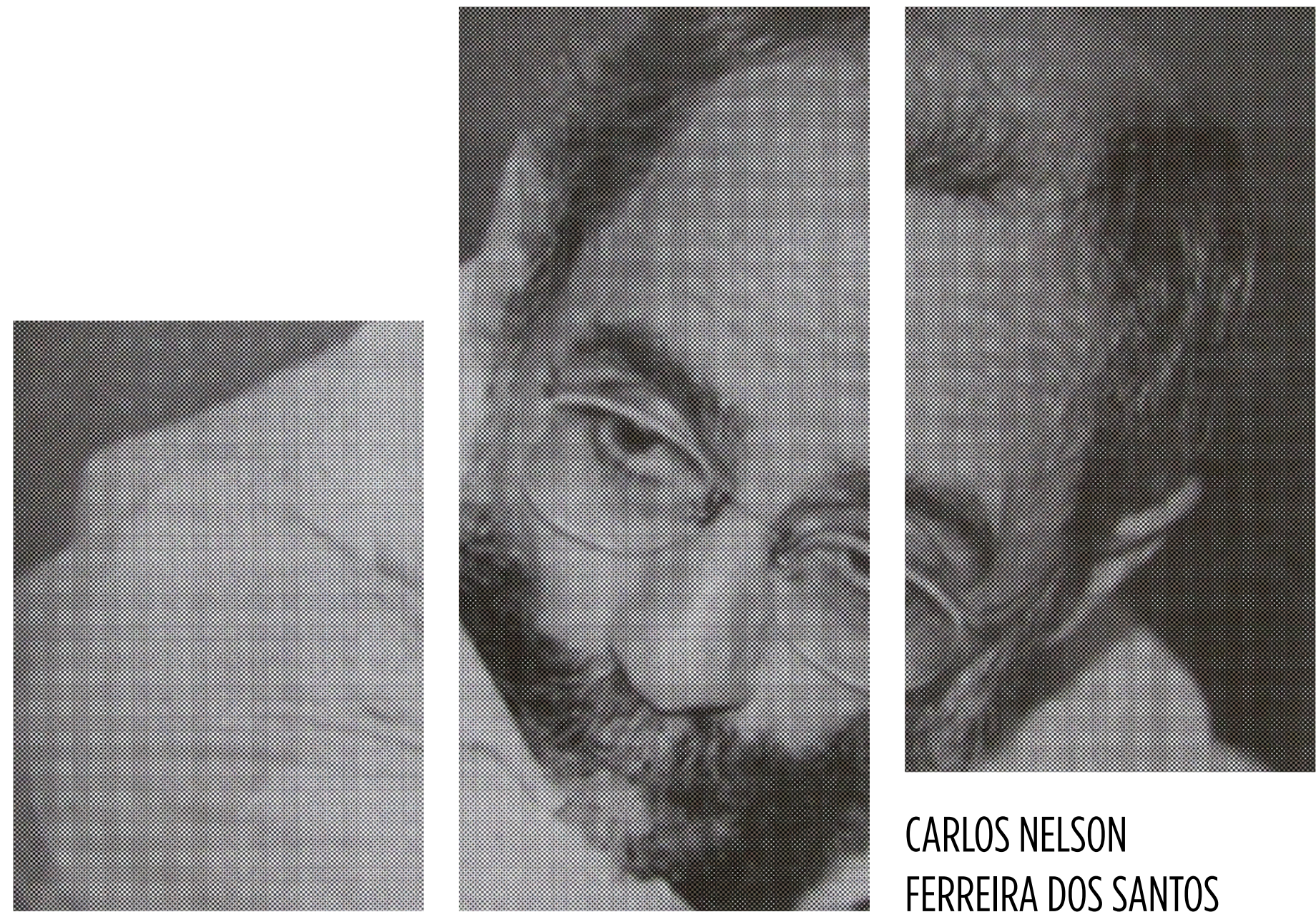

\section{CARLOS NELSON FERREIRA DOS SANTOS}

(1943 - 1989)

\section{Formação}

- 1984

Doutorado em Arquitetura e Urbanismo pela Faculdade de Arquitetura e Urbanismo da Universidade de São Paulo FAUUSP, São Paulo, Brasil

Título: Formações Metropolitanas no Brasil

\section{4 - 1979}

Mestrado em Antropologia Social no Museu Nacional da Universidade Federal do Rio de Janeiro, UFRJ, Rio de Janeiro,

\section{Brasil}

Título: Três Movimentos Sociais Urbanos no Rio de Janeiro

1971

Pesquisador visitante no Departamento de Estudos Urbanos do Massachusetts Institute of Technology - MIT-EEUU, EUA

1962 - 1966

Graduação em Arquitetura e Urbanismo pela Faculdade Nacional de Arquitetura da Universidade Federal do Rio de Janeiro (atual FAU UFRJ,) Rio de Janeiro, Brasil 


\section{OUTRAS EXPERIÊNCIAS RELEVANTES EXPERIÊNCIAS RELEVANTES COM FAVELAS}

1975 - 1989

Gestão / Planejamento

Centro de Pesquisas Urbanas, Instituto Brasileiro de Administração Municipal IBAM, Rio de Janeiro

Função: assessor especial e (posteriormente) diretor

Breve descrição: centro de pesquisa e planejamento. No período é participante e autor das pesquisas que geram produtos referência do planejamento urbano, entre eles: Quando a Rua Vira Casa (1981) livro e roteiro do filme; A Cidade como um Jogo de Cartas (1988), fruto da tese apresentada para o curso de professor titular da

UFF, Seis Novas Cidades em Roraima, (1985) estudo realizado pelo Ibam em 1985; e da série de artigos publicados na seção Cartas Urbanas da revista Projeto, criada especialmente para ele nos anos 1980.

Observações: em 1988, recebe o Prêmio Pereira Passos por sua contribuição à capital fluminense.

$-1989$

Acadêmico

Escola de Arquitetura e Urbanismo da Universidade Federal Fluminense, UFF, Niterói, Rio de Janeiro

Função: docente no programa de mestrado

$-1989$

Acadêmico

Curso de Geografia Econômica Industrial, UFRJ

Função: docente na graduação Observações: a tese apresentada para o curso de professor titular da UFF em 1985 gera o livro A Cidade como um Jogo de

Cartas (1988).

1964 -

Gestão / Planejamento / Projeto

Quadra Arquitetos Associados Ltda

Função: arquiteto urbanista, membrofundador

Breve descrição: a Quadra Arquitetos foi fundada por Carlos Nelson e os colegas de FAU Sylvia Lavenère-Wanderley, Sueli

de Azevedo e Rogério Aroeira Neves. Juntos para além das experiências com a FAFEG, procuram desenvolver experiências que tensionavam o lugar-comum do arquiteto e a forma de se colocar perante a realidade que os envolvia.

\section{8 - 1971}

Planejamento / Projeto

Urbanização de Brás de Pina

Função: arquiteto urbanista [Quadra Arquitetos]

VER FICHA DE PROJETO em Cap.2

\section{7}

Planejamento

Levantamento urbanístico de três favelas cariocas, Rio de Janeiro Agente Organizador: Centro de Pesquisas Habitacionais - CENPHA, Grupo de Trabalho - GT 3881

Agente Contratante: Companhia do Progresso do Estado da Guanabara - COPEG, Banco Nacional de Habitação - BNH Função: arquiteto urbanista [Quadra Arquitetos]

Escopo: Levantamentos e estudos de viabilidade que contemplavam: pesquisa socioeconômica, pesquisa urbanística, pesquisa habitacional, pesquisa artesanal, jurídica e pesquisa de viabilidade econômico-financeira.

Breve descrição: as 3 favelas eram: Brás de Pina, Mata Machado e Morro União Observações: posteriormente a Quadra Arquitetos só foi contratada para desenvolver projeto e plano de intervenção em Brás de Pina.

1964 - 1966

Acadêmico / Outro

Movimento estudantil e do trabalho de medicina social e sanitária em favelas cariocas Catumbi e São Carlos, Rio de Janeiro

Agente Organizador: Movimento estudantil - Faculdade de Medicina e Federação de Favelas do Estado da Guanabara - FAFEG

Função: participante, assessor urbanístico e habitacional da FAFEG

Observações: trabalho voluntário de fundamento politico-militante 


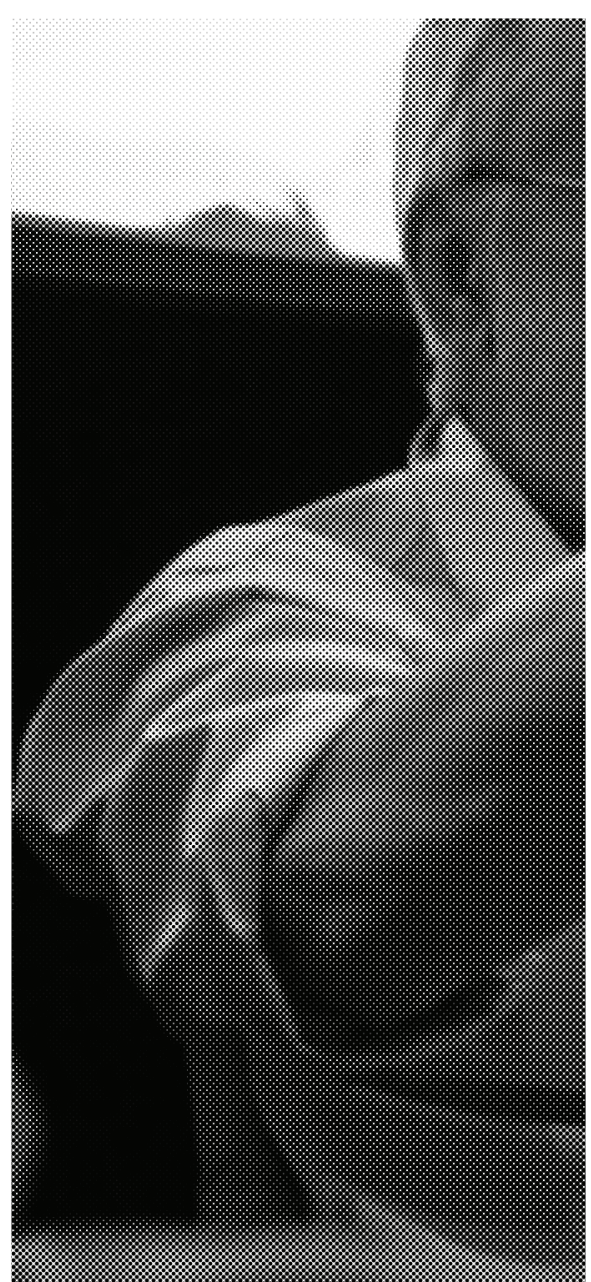

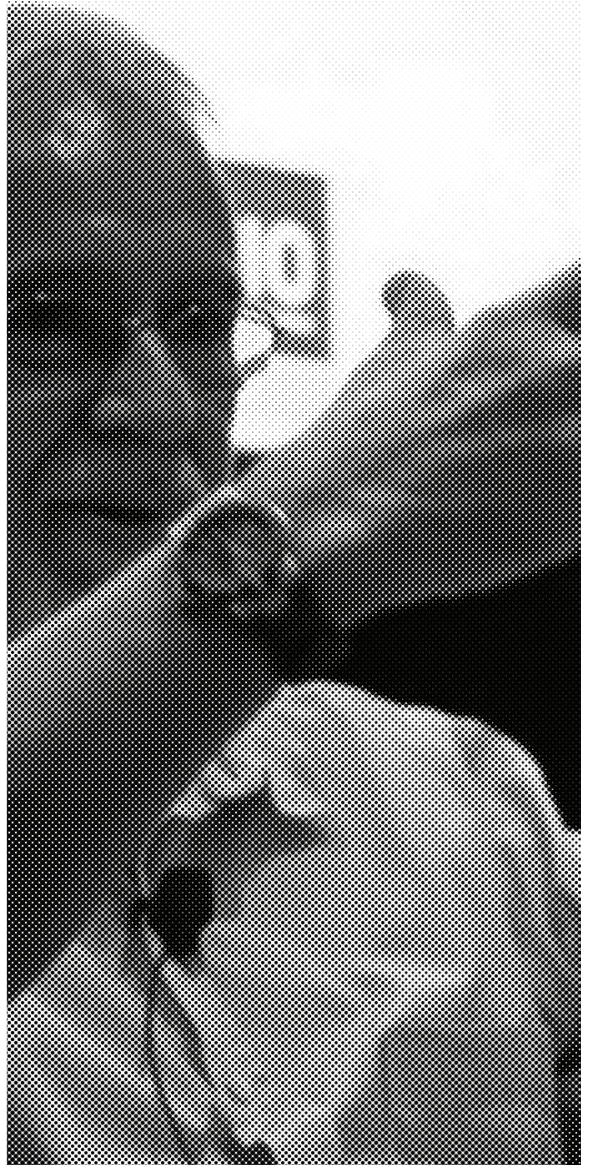

\section{MANOEL RIBEIRO}

(1941)

\section{Formação}

1962 - 1967

Graduação em Arquitetura e Urbanismo pela Faculdade Nacional de Arquitetura da Universidade Federal do Rio de Janeiro (atual FAU UFRJ,) Rio de Janeiro, Brasil

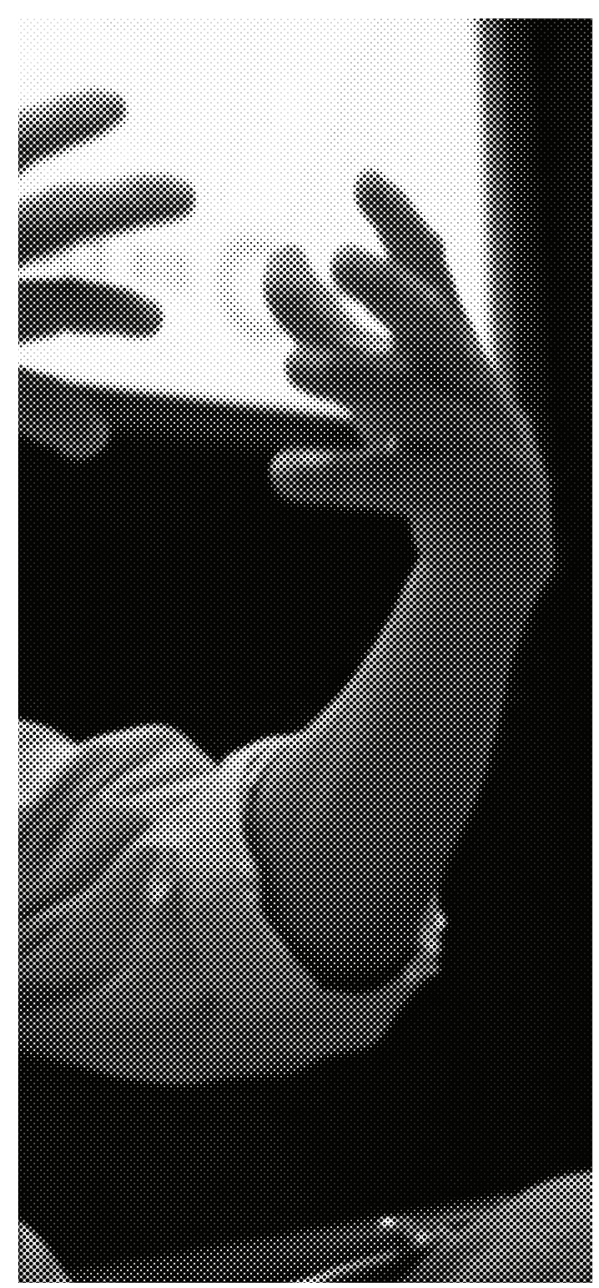




\section{OUTRAS EXPERIÊNCIAS RELEVANTES EXPERIÊNCIAS RELEVANTES COM FAVELAS}

2012 - em andamento

Planejamento

Plano Diretor de Petrópolis, Rio de

Janeiro

Agente Organizador: Prefeitura Municipal de Petrópolis

Agente Contratante: Prefeitura Municipal de Petrópolis

Função: Coordenador Geral Breve descrição: elaboração e responsável pelas revisões. $O$ trabalho teve caráter eminentemente participativo, contando com a colaboração de várias entidades profissionais (FIRJAN, APEA, OAB) e da sociedade civil (Frente Pró-Petrópolis e Igrejas Pentecostais).

2012 - 2016

Planejamento

Porto Novo, Rio de Janeiro Função: consultor

Breve descrição: Estudos sobre perspectivas de desenvolvimento imobiliário no entorno da área do Porto Maravilha, no Rio de Janeiro.

O trabalho visava a recuperação das áreas protegidas, do sec. XIX/XX, do retro-porto, de modo a conservar sua população original e redinamizar os usos tradicionais.

\section{5}

Acadêmica

Semana do Urbanismo, Mindelo, Cabo Verde

Agente Organizador: curso de Arquitetura da MINDELO_Escola Internacional de ARTE - M_EIA, Cabo Verde

Função: Palestrante e Professor Convidado

Breve descrição: Orientação de trabalhos de cartografia crítica e propostas de intervenção urbana em assentamentos precários e informais em Cabo Verde, para a população mais carente da ilha do Mindelo. Em colaboração com o Prof. Nuno Flores, foi desenvolvida uma experiência com os alunos do $1^{\circ}$ ano de arquitetura, visando dotar esses assentamentos de uma infraestrutura mínima, capaz de evoluir no tempo. 
OUTRAS EXPERIÊNCIAS RELEVANTES EXPERIÊNCIAS RELEVANTES COM FAVELAS

2008-2009

Gestão

CAIXA - Caixa Económica Federal

Observações: Criação do Centro de Cidadania da CAIXA, posteriormente, integrado ao movimento Viva Rio.

\section{0}

Planejamento / Projeto / Outros

Concurso Morar Carioca, Rio de Janeiro - RJ

Agente Organizador: Prefeitura do Rio de Janeiro e IAB-RJ

Função: arquiteto e urbanista, coordenador técnico

Escopo: Concurso público de metodologias para intervenção em assentamentos precários e Desenvolvimento de projetos de Urbanização de Favelas

Breve descrição $O$ concurso visava a seleção de 40 equipes interdisciplinares que seriam contratadas para desenvolver projetos para favelas do município do Rio de Janeiro, para cumprir a meta de urbanizar todas as favelas até 2020.

Observações: Proposta selecionada. Chegou a assinar contrato e a iniciar os trabalhos de levantamento e diagnóstico na favela designada para intervenção, antes da formalização do pagamento por recear não ter tempo para concluir essa etapa. O contrato nunca avançou nem teve uma resposta formal por parte da prefeitura, e os trabalhos foram suspensos.

\section{8 - 2009}

Projeto

Vale do Reginaldo, Maceió

Função: Coordenador de aspectos sociais e urbanísticos [Quanta Consultoria] Breve descrição: Acompanhamento e planejamento da remoção, realocação e reassentamento no mesmo local. Acompanhamento da construção das novas habitações. Assentamento de tamanho reduzido, num vale localizado muito próximo ao Centro de Maceió.

\section{6}

Projeto / Planejamento

Concurso de Ideias para Urbanização da Rocinha, Rio de Janeiro

Agente Organizador: EMOP (Empresa Metropolitana de Obras Públicas do Estado do Rio de Janeiro) e IAB-RJ

Função: Arquiteto coordenador-geral Breve descrição: As ideias que foram desenvolvidas para o concurso foram discutidas com as populações dos diversos segmentos da favela, definidos por tipologia de ocupação. Na proposta destacamse a implementação de um centro esportivo localizada no centro geométrico da Rocinha e uma passarela de travessia da via rápida, limítrofe da Rocinha, onde era considerada a permanência de barracas do camelô, usuais naquela localização. Observação: A proposta de Manoel Ribeiro e equipe ficou em $2 \circ$ lugar. Em primeiro lugar ficou a proposta coordenada por Luiz Carlos Toledo. 


\section{EXPERIÊNCIAS RELEVANTES COM FAVELAS}

1999-2003

Projeto

Cantagalo e Pavão-Pavãozinho,

Programa Favela-Bairro, Rio de Janeiro

Função: consultor e, posteriormente,

Coordenador de Urbanismo [MPS associados e MET]

VER FICHA DE PROJETO em Cap.2

2002

Projeto

PROSAMIM, Manaus

Função: Coordenador - Gerenciamento aspectos sociais [Consórcio Engevix / Quanta Consultoria]

Breve descrição: Acompanhamento e planejamento da remoção, realocação e reassentamento de famílias moradoras em assentamento precário. Acompanhamento da construção das novas habitações.

Observação: As negociações e ferramentas de planejamento, acompanhamento e controle utilizados, foram adotados pelo BID em outros projetos.

\section{6-2001}

Projeto / Obra

Serrinha, Programa Favela-Bairro, Rio de Janeiro

Função: arquiteto e urbanista, coordenador de projeto e obra

VER FICHA DE PROJETO em Cap.2

\section{4}

Projeto

Casa da Paz, Vigário Geral, Rio de Janeiro

Agente Organizador: Organizações locais de moradores

Agente Contratante: CAIXA Económica Federal

Função: arquiteto projetista

Breve descrição: Casa-sede da ONG Casa da Paz em memória da Chacina de Vigário Geral. O prédio foi reformado para se transformar num centro de capacitação profissional e cultural.

Observações: A sequência destes episódios foi descrita por Zuenir Ventura, em seu livro Cidade Partida. Hoje a Casa da Paz não funciona mais. 

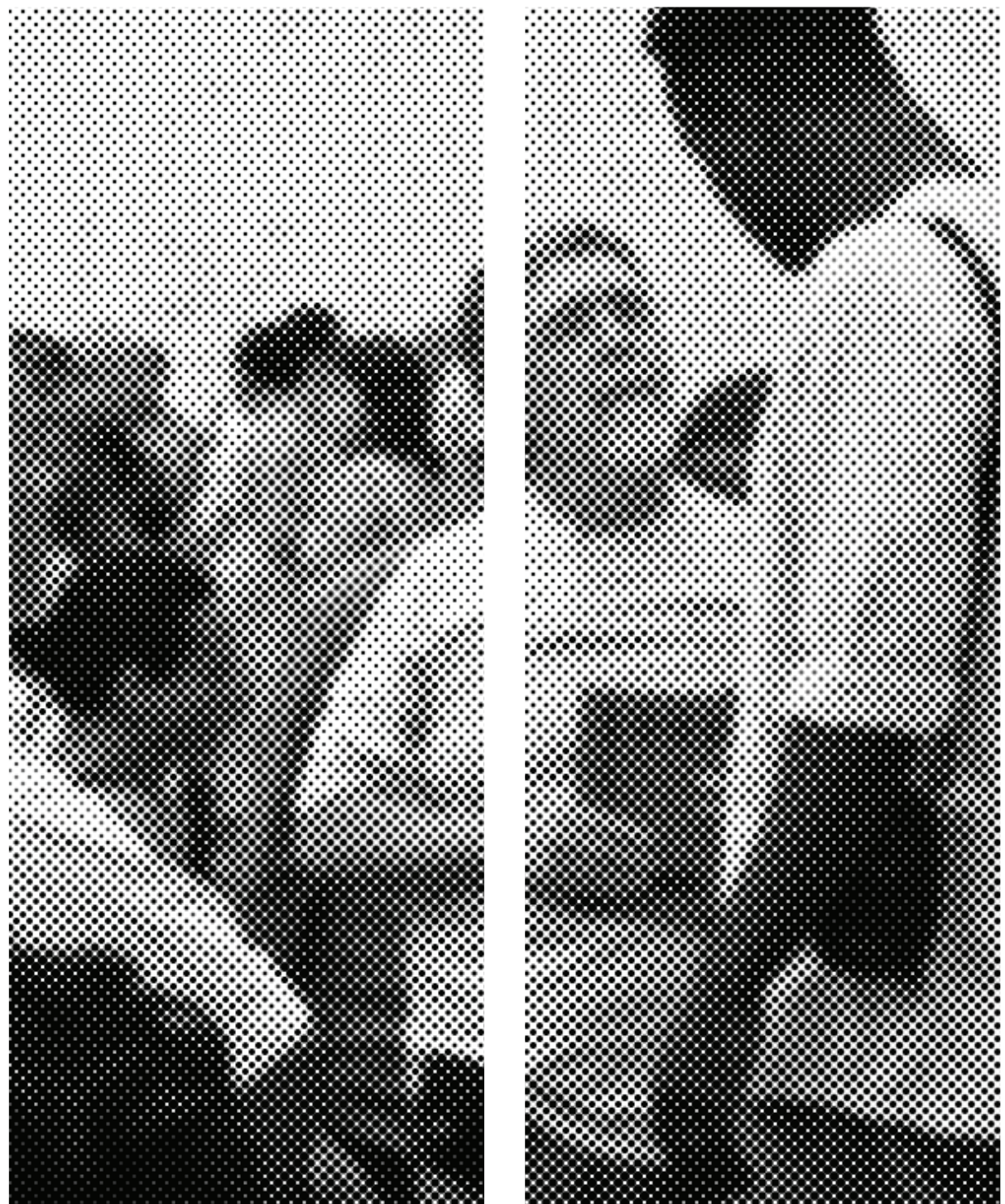

\section{LUIZ CARLOS DE MENEZES TOLEDO \\ (1943)}

\section{Formação}

2004 - 2008

Doutorado em Teoria e Projeto de Arquitetura pelo PROARQ da Faculdade de Arquitetura e Urbanismo da Uuniversidade Federal do Rio de Janeiro - FAU UFRJ

Título: Feitos para Cuidar: a arquitetura como um gesto médico e a humanização do edifício hospitalar

Orientador: Vera Regina Tângari / Antônio Pedro Carvalho

\section{0 - 2002}

Mestrado em Teoria da Arquitetura pelo PROARQ, FAU-UFRJ

Título: Feitos para curar: metodologia projetual de edificações de saúde

Orientador: Vicente Del Rio / Vera Regina Tângari

\section{8}

Curso de Pós-Graduação Especialização em Urbanismo, FAU UFRJ

1961 - 1966

Graduação em Arquitetura e Urbanismo pela Faculdade Nacional de Arquitetura da Universidade Federal do Rio de Janeiro (atual FAU UFRJ,) Rio de Janeiro, Brasil 


\section{OUTRAS EXPERIÊNCIAS RELEVANTES EXPERIÊNCIAS RELEVANTES COM FAVELAS}

\section{6 - atual}

Gestão

Mayerhofer $\&$ Toledo Arquitetura, Planejamento e Consultoria Ltda - M\&T Arquitetos, Rio de Janeiro Função: Sócio Diretor Breve descrição: Com 30 anos de funcionamento, um portfólio variado e apoiada por consultores independentes especializados em diversas disciplinas, a M\&T tem

o perfil ideal para elaborar projetos que exijam um tratamento interdisciplinar nas

mais diversas áreas

1977-2014 (aposentado) Acadêmica

Faculdade de Engenharia, Universidade do Estado do Rio de Janeiro (UERJ)

Função: Professor Adjunto de Urbanismo
2014

Acadêmica

Repensando as habitações de interesse social, (TOLEDO, L., VRCIBRADIC, P., NATIVIDADE, V., Letra Capital, Rio de Janeiro, 2014

Agente Organizador: UFRJ/IPPUR Agente Contratante: Rede FINEP sobre Moradia e Tecnologia Social; colaboração UFRJ/PROARQ - Programa de Pós Graduação em Arquitetura da UFRJ; Apoio do CNPq e patrocínio do CAU/RJ

Função: Pesquisador, coordenador de pesquisa, autor

Observações: Pesquisa e Livro sobre Habitações de Interesse Social, com base nas experiências profissionais dos autores, sobretudo a experiência vivida por Toledo na Rocinha, e questionando as políticas e programas habitacionais públicos colocados.

\section{0}

Planejamento / Projeto / Outros

Concurso Morar Carioca, Rio de Janeiro - RJ Agente Organizador: Prefeitura do Rio de Janeiro e IAB-RJ

Função: arquiteto e urbanista, consultor técnico especializado [equipe coordenada por Jonathas Silva]

Escopo: Concurso público de metodologias para intervenção em assentamentos precários e Desenvolvimento de projetos de Urbanização de Favelas

Breve descrição $O$ concurso visava a seleção de 40 equipes interdisciplinares que seriam contratadas para desenvolver projetos para favelas do município do Rio de Janeiro, para cumprir a meta de urbanizar todas as favelas até 2020.

Observações: Premiado com destaque. Foram uma das 5 equipes destacadas pelo Júri em função da pertinência metodológica. A área destinada seria Realengo e Vila Vintém localizado na zona Oeste do Rio. Poucas das equipes selecionadas para desenvolver projetos, foram efetivamente contratadas. 
EXPERIÊNCIAS RELEVANTES COM FAVELAS

2007 - 2008

Planejamento / Projeto

Plano Sócio-Espacial da Rocinha, Rio de Janeiro

Função: Arquiteto coordenador-geral [M\&T]

VER FICHA DE PROJETO em Cap.2

2006

Planejamento / Projeto

Concurso de Ideias para Urbanização da Rocinha, Rio de Janeiro

Agente Organizador: EMOP e IAB-RJ

Função: Arquiteto, coordenador-geral [M\&T]

Breve descrição: Concurso Nacional de Ideias para Urbanização da Rocinha promovido pelo Governo do Estado do Rio de Janeiro e organizado pelo IAB-RJ. Observações: 1ํ Lugar, o que valeu a contratação para o desenvolvimento do Plano Sócio-Espacial. O destaque do júri foi em função do método proposto que tinha como premissa a construção de um plano junto com os moradores.

\section{9-2003}

Projeto

Cantagalo e Pavão-Pavãozinho, Programa Favela-Bairro, Rio de Janeiro

Função: representante legal do escritório [MPS associados e M\&T]

VER FICHA DE PROJETO em Cap.2

2002

Projeto

Urbanização da Área portuária, Morro do Livramento, Rio de Janeiro

Agente Organizador: Prefeitura do Município do Rio de Janeiro e IPP- Instituto Pereira

Agente Contratante: Prefeitura do $\mathrm{Mu}-$ nicípio do Rio de Janeiro e IPP- Instituto Pereira

Escopo: Projeto de urbanização envolvendo área habitacional com projetos de Drenagem, Iluminação Pública, Urbanismo e Paisagismo. Urbanização do Morro do Livramento na área portuária do Rio de Janeiro. 


\section{EXPERIÊNCIAS RELEVANTES COM FAVELAS}

2002

Projeto

Favela Vila Mangueiral, Programa Favela

-Bairro, Rio de Janeiro

Agente Organizador: Secretaria Municipal de Habitação, SMH, Prefeitura do Município do Rio de Janeiro

Agente Contratante: Programa Favela-Bairro, SMH, Habitar Brasil-BID (Banco Americano de Desenvolvimento)

Escopo: Desenvolvimento de projetos de unidades habitacionais, creche e centro de apoio social assim como os projetos de Água, Esgoto, Drenagem, Iluminação Pública, Sistema Viário, Paisagismo, Mobiliário Urbano e delimitação de AEIS.

Observação: Com a interrupção do Programa Favela Bairro as obras previstas no projeto não foram realizadas.

1998-1999

Projeto

Vila Olímpica da Rocinha, Rio de Janeiro

Agente Organizador: Associação de Moradores da Rocinha

Função: Projetista, coordenador

Breve descrição: O projeto consistiu numa laje de aproximadamente 200 metros de comprimento por 33 metros de largura erguida sobre a Estrada Lagoa Barra, desde a saída do Túnel Zuzu Angel até a antiga passarela da Rocinha. Sobre a laje foram projetadas um conjunto de quadras esportivas, áreas para biblioteca, ensaios de teatro e dança, academia de ginástica, pista de skate, playground, praça e anfiteatro para a realização de eventos, piscina semi-olímpica e piscina infantil. $O$ projeto promoveria integração espacial e social ao Bairro de São Conrado."

Observação: O projeto da Vila Olímpica da Rocinha fez parte de um conjunto de pequenas intervenções na favela que tiveram origem no contato de alguns moradores da Rocinha com o Toledo, que o procuraram em seu escritório, com o pedido de "embelezar" Rocinha, e a partir das referências de intervenção feitas por Toledo no Meyer dentro do Programa Rio-Cidade. O projeto foi contratado pela Prefeitura da época, mas, acabou não foi construído devido a troca da administração municipal. 


\section{OUTRAS EXPERIÊNCIAS RELEVANTES}

1997-1998

Planejamento / Projeto

Rio-Cidade Irajá, Rio de Janeiro - RJ Agente Organizador: Prefeitura do Município do Rio de Janeiro, IAB e a IPLANRIO Agente Contratante: Programa Rio-Cidade, Prefeitura do Município do Rio de Janeiro

Função: Projetista, Coordenador de Projeto [M\&T]

Breve descrição: A M\&T venceu em 1997 o concurso público de âmbito nacional promovido pela prefeitura Municipal da

Cidade do Rio de Janeiro para seleção das equipes de elaboração do Rio-Cidade 2. Coube à M\&T a tarefa de desenvolver o Projeto Rio Cidade Irajá, que requalifica 12 ha localizados na área central deste subúrbio carioca."

Planejamento / Projeto

Projeto Baixada Viva, Baixada

Fluminense, Rio de Janeiro

Agente Organizador: Secretaria Estadual de Planejamento do Estado do Rio de Janeiro - SECPLAN

Agente Contratante: Programa Rio-Cidade, Prefeitura do Município do Rio de Janeiro Função: Projetista e Coordenador de Projeto [M\&T]

Breve descrição: A M\&T venceu em 1997 concurso público de âmbito nacional para

a seleção de equipe de elaboração do Projeto Baixada Viva, abrangendo propostas urbanísticas e de desenho urbano para oito bairros localizados na Baixada Fluminense. Observação: $O$ trabalho destacou-se por criar um conjunto variado de mobiliários urbanos muito simples, capazes de serem construídos por mão de obra local com pouca capacitação.

1993-1997

Planejamento / Projeto

Rio-Cidade Méier, Rio de Janeiro - RJ Agente Organizador: Prefeitura do Município do Rio de Janeiro, IAB e a IPLANRIO Agente Contratante: Programa Rio-Cidade, Prefeitura do Município do Rio de

Janeiro

Função: Projetista, coordenador [M\&T] Breve descrição: Vencedora do Concurso RIO CIDADE, a M\&T foi contratada para desenvolver e acompanhar a implantação do projeto de requalificação urbana do centro funcional do Méier.

Observação: $O$ projeto foi a referência para a primeira aproximação dos moradores da Rocinha ao escritório e a Toledo, pedindo um projeto da sua autoria para a comunidade. 


\section{OUTRAS EXPERIÊNCIAS RELEVANTES EXPERIÊNCIAS RELEVANTES COM FAVELAS}

1982-1983

Tipo: Gestão

Fundação para o Desenvolvimento da Região Metropolitana do Rio de Janeiro, FUNDREM

Função: Coordenador de Desenvolvimento Urbano

Observação: Neste período foi realizado pela FUNDREM o Plano Diretor da Região Metropolitana do Rio de Janeiro.

1980

Gestão

RIOPLAN - Fundação Municipal de Planejamento - atual Instituto Pereira

Passos

Função: Diretor

Breve descrição: O Instituto Municipal de Urbanismo Pereira Passos (IPP) teve sua origem na Fundação RioPlan, instituída em 1979, Toledo participou da primeira diretoria, ocupando a Diretoria de Planejamento, sob a presidência de Wagner Siqueira, responsável pela estruturação da fundação.

1979-1980

Gestão

Instituto Brasileiro de Planejamento, IBP Função: Diretor

1977-1983 Acadêmica / Gestão

Curso de Pós-Graduação em

Planejamento Urbano e Regional, UERJ

Função: Coordenador e Professor

1977-1985

Acadêmica / Gestão

Faculdade de Engenharia, UERJ

Função: Chefe de Departamento Urbano e Tecnologia da Habitação
1968

Planejamento / Projeto

Urbanização de Favela Cerro Corá, RJ Agente Organizador: Associação dos Moradores do Cerro Corá Agente Contratante: Programa Cargo Função: Arquiteto consultor

Breve Descrição: Consultoria Pro Bono prestada à: Associação dos Moradores do Cerro Corá, juntamente com os arquitetos Roberto Cavalcanti e Celso de Omena Brando sobre a urbanização da favela, no que se refere a identificação das áreas de risco, saneamento e construção de moradias.

Observação: A relação com a comunidade foi terminada, por denúncia de regularidades às então vigentes autoridades (período de ditadura civil-militar) 

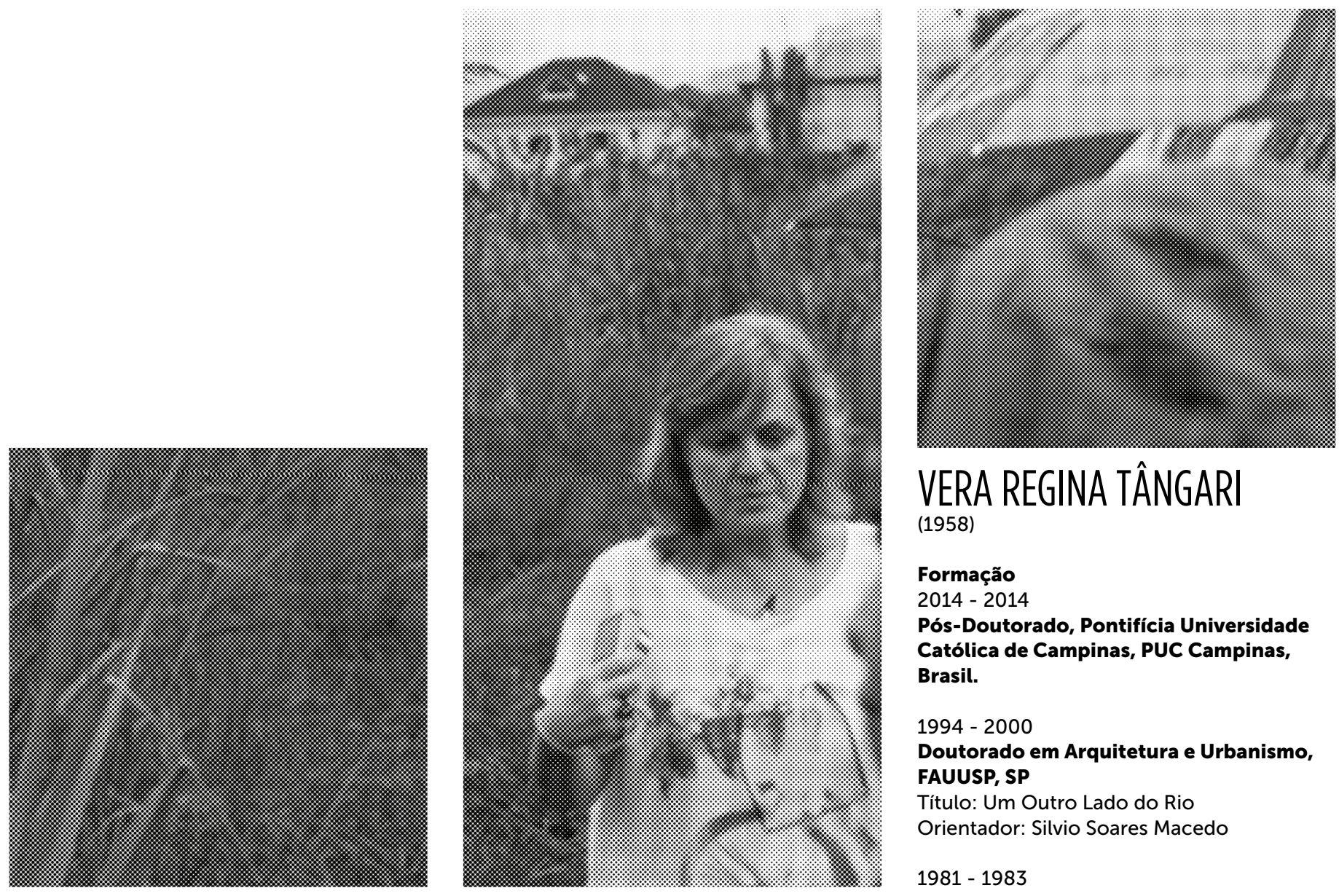

VERA REGINA TÂNGARI (1958)

\section{Formação}

2014 - 2014

Pós-Doutorado, Pontifícia Universidade Católica de Campinas, PUC Campinas, Brasil.

\section{$1994-2000$}

Doutorado em Arquitetura e Urbanismo, FAUUSP, SP

Título: Um Outro Lado do Rio

Orientador: Silvio Soares Macedo

$1981-1983$

Mestrado em Urban Planning, University Of Michigan, UOFM, EUA

Título: Barra do Corda: uma Comunidade Rural no Brasil

Orientador: Ann Arbor / Allan G. Feldt.

$1976-1981$

Arquiteta Urbanista, Instituto Metodista Bennett, RJ 


\section{OUTRAS EXPERIÊNCIAS RELEVANTES EXPERIÊNCIAS RELEVANTES COM FAVELAS}

\section{1 - atual \\ Gestão \\ 2016 - atual \\ Acadêmica}

MPS associados ltda, São Paulo

Função: consultora

Breve descrição: Fundada em 1994, a empresa MPS associados ltda presta serviços de consultoria, elaboração de projetos e gerenciamento nas áreas de Arquitetura, Urbanismo, Planejamento,

Paisagismo e Comunicação Visual / Identidade Coorporativa. A característica multidisciplinar de seu corpo técnico, constituído por arquitetos urbanistas, apoiados por consultores independentes especializados em diversas áreas, confere à MPS o perfil ideal para elaborar projetos e planos que exijam um tratamento interdisciplinar.

1994 - atual

Acadêmica

Faculdade de Arquitetura e Urbanismo, Universidade Federal do Rio de Janeiro

- FAU UFRJ

Função: Professor associado III

Breve descrição: Ensino na graduação e pós-graduação, Pesquisa na pósgraduação, Extensão na graduação. Coordenação geral do Programa de PósGraduação em Arquitetura - PROARQ da FAU/UFRJ (2010-2013)

$2006-2007$

Planejamento / Outros

Projeto Madeira - Projeto Participativo junto a População Ribeirinha do Rio

Madeira, Rondônia

Agente Organizador: Consórcio Furnas/

Odebrecht

Agente Contratante: Consórcio Furnas/

Odebrecht

Função: Consultora, Arquiteta Urbanista, mediadora [MPS associados]

Breve descrição: Condução de Processo Participativo com as populações ribeirinhas localizadas entre Calama e Fortaleza do Abunã para construção de propostas mitigadoras aos impactos das Hidrelétricas de Santo Antônio e Jirau previstas para serem construídas junto ao rio Madeira.
FAU-UFRJ - Escritório Modelo "Abricó"

Função: Orientadora de Grupos de

Extensão Universitária - Escritório Modelo da FAU-UFRJ "Abricó"

Breve descrição: Acompanha grupos de extensão universitária que têm feito intervenções em favelas e comunidades do Rio de Janeiro. Comunidade Babilônia (Copacabana/Rio de Janeiro - RJ); Assentamento MST Terra Prometida (Nova Iguaçu/RJ)

2010

Planejamento / Projeto / Outros

Concurso Morar Carioca, Rio de Janeiro Agente Organizador: Prefeitura do Rio de Janeiro e IAB-RJ

Função: arquiteta e urbanista, [equipe coordenada por Jonathas Silva]

Breve descrição: (ver em Luiz Carlos Toledo)

2007 - 2008

Planejamento / Projeto

Plano Sócio-Espacial da Rocinha, Rio de Janeiro

Função: Responsável pelo projeto paisagístico dos espaços livres de edificação [M\&T]

VER FICHA DE PROJETO em Cap.2 


\section{OUTRAS EXPERIÊNCIAS RELEVANTES}

$2004-2006$

Planejamento / Projeto

Planos Diretores Participativos Itapetininga (SP), Avaré (SP) e SEBRAE-

ES e Governo de Estado do Espírito

Santo (ES) - 11 cidades

Agente Organizador: Prefeituras Municipais (SP) e Governo de Estado do Espírito

Santo (ES), SEBRAE-ES

Agente Contratante: Prefeituras Municipais (SP) e Governo de Estado do Espírito

Santo (ES), SEBRAE-ES, MinCidades

Função: arquiteta urbanista, mediador, formador [MPS associados]

Breve descrição: Desenvolveu dos Planos

Diretores Participativos e capacitação de

comissões dos planos dos municípios.

Observação: Os resultados do trabalho em ES foram publicados pelo Ministério na Cidade em seu Banco de Experiências disponibilizado via internet.
EXPERIÊNCIAS RELEVANTES COM FAVELAS

2006

Planejamento / Projeto

Concurso de Ideias para Urbanização da Rocinha, Rio de Janeiro

Agente Organizador: EMOP e IAB-RJ

Função: Arquiteta Paisagista [M\&T]

Breve descrição: (ver em Luiz Carlos

Toledo)

\section{9-2003}

Projeto

Cantagalo e Pavão-Pavãozinho, Programa Favela-Bairro, Rio de Janeiro

Função: Arquiteta nos projetos de urbanização, paisagismo e de equipamentos públicos [MPS associados e M\&T]

VER FICHA DE PROJETO

\section{2}

Projeto

Urbanização da Área portuária, Morro do Livramento Rio de Janeiro

Agente Organizador: Prefeitura do $\mathrm{Mu}$ nicípio do Rio de Janeiro e IPP- Instituto Pereira

Agente Contratante: Prefeitura do $\mathrm{Mu}$ nicípio do Rio de Janeiro e IPP- Instituto Pereira

Função: arquiteta em projeto de reurbanização e paisagismo [MPS associados e M\&T]

Escopo: (ver em Luiz Carlos Toledo)
1997-1998

Planejamento / Projeto

Rio-Cidade Irajá, Rio de Janeiro - RJ

Agente Organizador: Prefeitura do

Município do Rio de Janeiro, IAB e a

IPLANRIO

Agente Contratante: Programa RioCidade, Prefeitura do Município do Rio de

Janeiro

Função: Projetista, Responsável por sistema de espaços livres [M\&T]

Breve descrição: (ver em Luiz Carlos 


\section{OUTRAS EXPERIÊNCIAS RELEVANTES EXPERIÊNCIAS RELEVANTES COM FAVELAS}

1997

Planejamento / Projeto

Projeto Baixada Viva, Baixada Fluminense, Rio de Janeiro

Agente Organizador: Secretaria Estadual de Planejamento do Estado do Rio de Janeiro - SECPLAN

Agente Contratante: Programa RioCidade, Prefeitura do Município do Rio de Janeiro

Breve descrição: (ver em Luiz Carlos Toledo)

1993-1997

Planejamento / Projeto

\section{Rio-Cidade Méier, Rio de Janeiro - RJ}

Agente Organizador: Prefeitura do Município do Rio de Janeiro, IAB e a

IPLANRIO

Agente Contratante: Programa RioCidade, Prefeitura do Município do Rio de Janeiro

Função: Projetista, Responsável por sistema de espaços livres [M\&T]

Breve descrição: (ver em Luiz Carlos Toledo)

1991 - 1991

Planejamento / Projeto

Instituto Brasileiro de Administração Municipal - IBAM, RJ

Função: arquiteta, urbanista Breve descrição: Desenvolvimento do Plano Diretor de São Joaquim da Barra/SP.

1986 - 1986

Planejamento / Projeto

IBAM, RJ

Função: arquiteta

Breve descrição: Projetos de paisagismo para o Programa Pró-Município - BNH/RJ.

1983 - 1985

Planejamento / Projeto

\section{Diretoria de Terras, Banco Nacional de}

Habitação - BNH, RJ

Função: estagiária

Breve descrição: Estudos de demanda habitacional e análise de planos diretores de desenvolvimento metropolitano.
1984

Planejamento / Projeto

Urbanização da Favela do Lixo, Petrópolis/RJ

Agente Organizador: Prefeitura do Município do Petrópolis

Agente Contratante: Prefeitura do Município do Rio de Janeiro e IPP- Instituto Pereira Função: Arquiteta

Breve descrição: O projeto foi licitado pela administração municipal e a empresa encarregada foi a Libonatti Associados que contratou equipe multidisciplinar incluindo arquitetos e assistentes sociais. Observação: Por divergências de orientação política, os arquitetos responsáveis e equipe não concluíram o projeto, optando por direcionar o trabalho aos moradores da comunidade. 


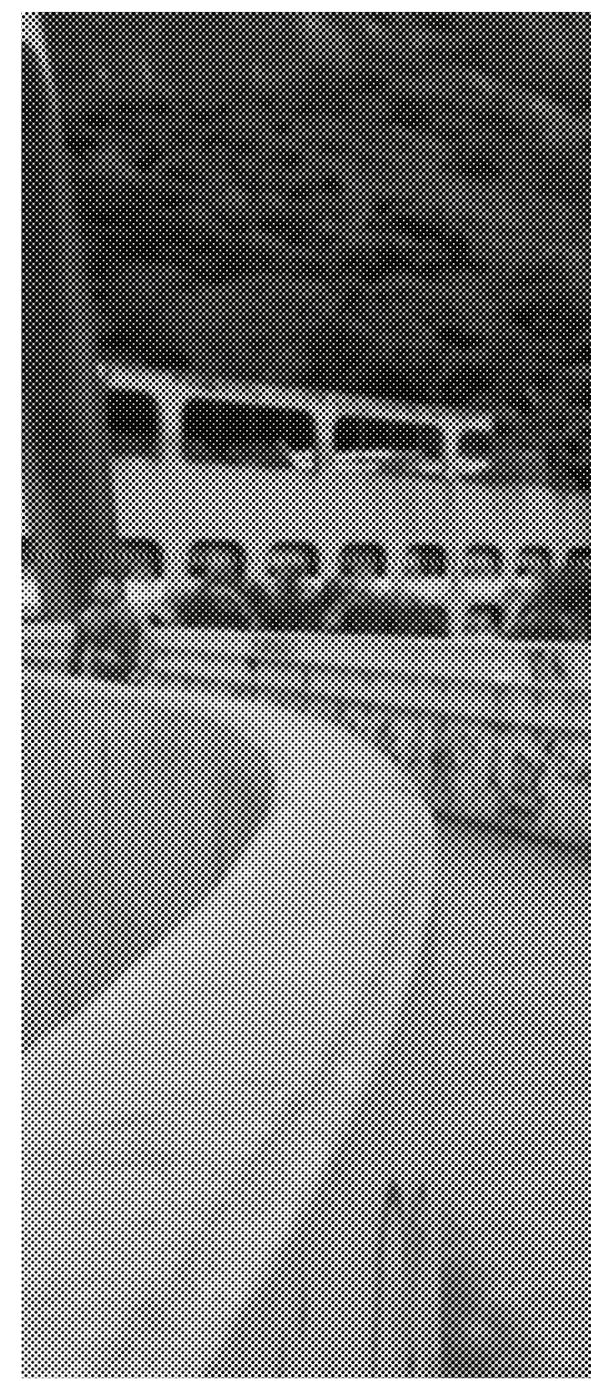

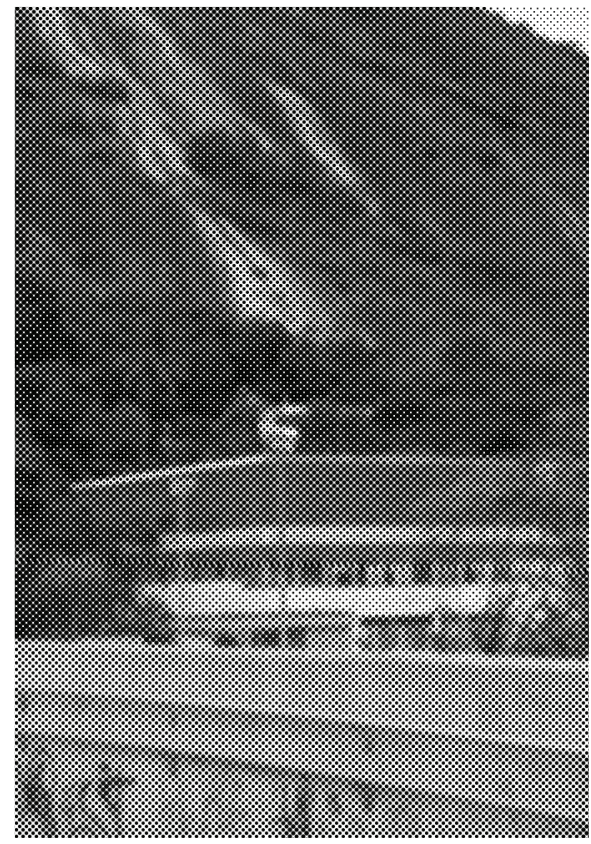

\section{JONATHAS MAGALHÃES PEREIRA DA SILVA (1963)}

\section{4}

Pós-Doutorado, FAU UFRJ, Brasil.

\section{1-2005}

Doutorado em Arquitetura e Urbanismo, FAUUSP, SP

Título: O papel da Disciplina de Paisagismo na formação do arquiteto urbanista

Orientador: Silvio Soares Macedo

Mestre em Arquitetura e Urbanismo, FAUUSP

1996 - 1999

Mestrado em Arquitetura e Urbanismo, FAUUSP, SP

Título: Paisagismo / Ensino / Interface Gráfica

Orientador: Silvio Soares Macedo

1984 - 1988

Graduação em Arquitetura e Urbanismo na FAUUSP, Brasil

\section{Formação Complementar}

2011

Mercados informales de suelo y Reg. de Asentamient. (Carga horária: 40h). Lincoln Institute of Land Policy, LILP, Estados Unidos.

\section{0}

Dimensión Jurídica de las Políticas de Suelo. (Carga horária: 56h). , Lincoln Institute of Land Policy, LILP, Estados Unidos.

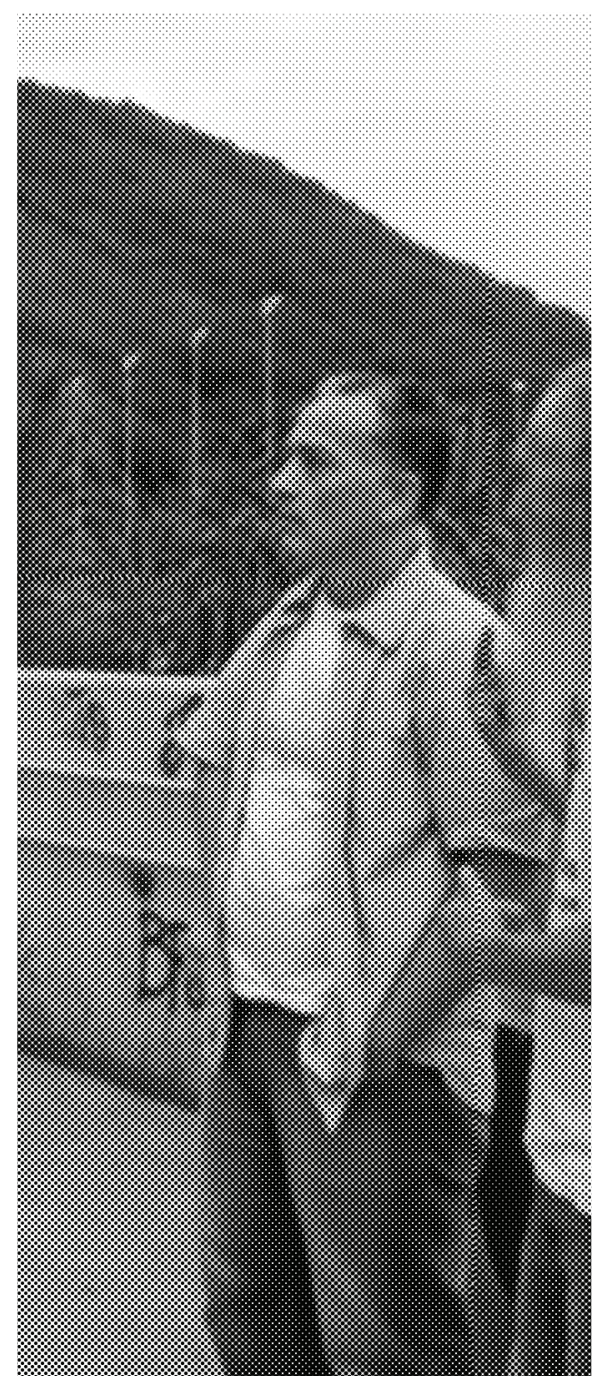




\section{OUTRAS EXPERIÊNCIAS RELEVANTES EXPERIÊNCIAS RELEVANTES COM FAVELAS}

\section{9 - atual \\ Acadêmica \\ Pontifícia Universidade Católica de Campinas, PUC Campinas}

Função: Docente e pesquisador, da PUCCampinas no curso de pós-graduação em Urbanismo (Mestrado e Doutorado) e na graduação da FAU PUC-Campinas.

Breve descrição: A atuação acadêmica sempre acompanhou as práticas profissionais em uma relação dialética de construção do conhecimento.

\section{4 - atual}

Gestão

MPS associados ltda, Brasil

Função: sócio-fundador

Breve descrição: (ver em Vera Tângari)
2011

Planejamento / Projeto / Outros

Concurso Renova SP, São Paulo - SP

Agente Organizador: Sehab, Prefeitura de São Paulo e IAB-SP

Função: arquiteto e urbanista, coordenador técnico

Escopo: Concurso público de projeto de urbanização, regularização de favelas e loteamentos precários

Breve descrição: Elaboração de propostas para urbanização e regularização de favelas e loteamentos precários, inseridos em Perímetros de Ação Integrada (PAI), que, por sua vez são baseados em Sub-bacias hidrográficas. A equipe desevolveu projetos para as áreas Aricanduva 5 e 6.

Observações: A proposta não foi selecionada, mas nenhuma outra foi selecionada para as essas áreas. A proposta considerava os processos de regularização concluídos e em curso, consolidando grande parte dos assentamentos, as diretrizes do edital apontavam para remoções da ordem de 60 a $80 \%$ em favelas consolidadas e bem localizadas como a Vila Curse.

\section{0}

Planejamento / Projeto / Outros

Concurso Morar Carioca, Rio de Janeiro - RJ

Agente Organizador: Prefeitura do Rio de Janeiro e IAB-RJ

Função: arquiteto e urbanista, coordenador técnico [equipe com Luiz Carlos Toledo e Vera Tângari]

Breve descrição: (ver em Luiz Carlos Toledo) 


\section{OUTRAS EXPERIÊNCIAS RELEVANTES}

2000 - 2008

Acadêmica

Faculdade de Arquitetura e Urbanismo, Universidade Anhembi Morumbi, UAM,

Brasil

Função: Docente de graduação, ministrando as disciplinas de Paisagismo,

Urbanismo e TFG.

2006 - 2007

Planejamento / Outros

Projeto Madeira - Projeto Participativo junto a População Ribeirinha do Rio

Madeira, Rondônia

Agente Organizador: Consórcio Furnas/

Odebrecht

Agente Contratante: Consórcio Furnas/ Odebrecht

Função: Consultor, Arquiteto Urbanista, mediador [MPS associados] Breve descrição: (ver em Vera Tângari)

2004 - 2006

Planejamento / Projeto

Planos Diretores Participativos - Itapetininga (SP), Avaré (SP) e SEBRAE-ES e Governo de Estado do Espírito Santo

(ES) - 11 cidades

Agente Organizador: Prefeituras Municipais (SP) e Governo de Estado do Espírito

Santo (ES), SEBRAE-ES

Agente Contratante: Prefeituras Municipais (SP) e Governo de Estado do Espírito

Santo (ES), SEBRAE-ES, MinCidades

Função: arquiteto urbanista, mediador, formador [MPS associados]

Breve descrição: (ver em Vera Tângari)
EXPERIÊNCIAS RELEVANTES COM FAVELAS

\section{7 - 2008}

Tipo: Planejamento / Projeto

Plano Sócio-Espacial da Rocinha, Rio de Janeiro

Função: Arquiteto Coordenador Técnico [M\&T]

VER FICHA DE PROJETO em Cap.2

2006

Planejamento / Projeto

Concurso de Ideias para Urbanização da Rocinha, Rio de Janeiro

Agente Organizador: EMOP e IAB-RJ Função: Arquiteto Coordenador Técnico [M\&T]

Breve descrição: (ver em Luiz Carlos Toledo)

\section{9-2003}

Projeto

Cantagalo e Pavão-Pavãozinho, Programa Favela-Bairro, Rio de Janeiro Função: Arquiteto nos projetos de urbanização, paisagismo e de equipamentos públicos [MPS associados e M\&T]

VER FICHA DE PROJETO em Cap.2

\section{2}

Projeto

Urbanização da Área portuária, Morro do Livramento Rio de Janeiro Agente Organizador: Prefeitura do Município do Rio de Janeiro e IPPInstituto Pereira

Agente Contratante: Prefeitura do Município do Rio de Janeiro e IPPInstituto Pereira

Função: Arquiteto nos projetos de urbanização e paisagismo [MPS associados e M\&T]

Escopo: (ver em Luiz Carlos Toledo) 
arquitetos militantes em urbanização de favelas 

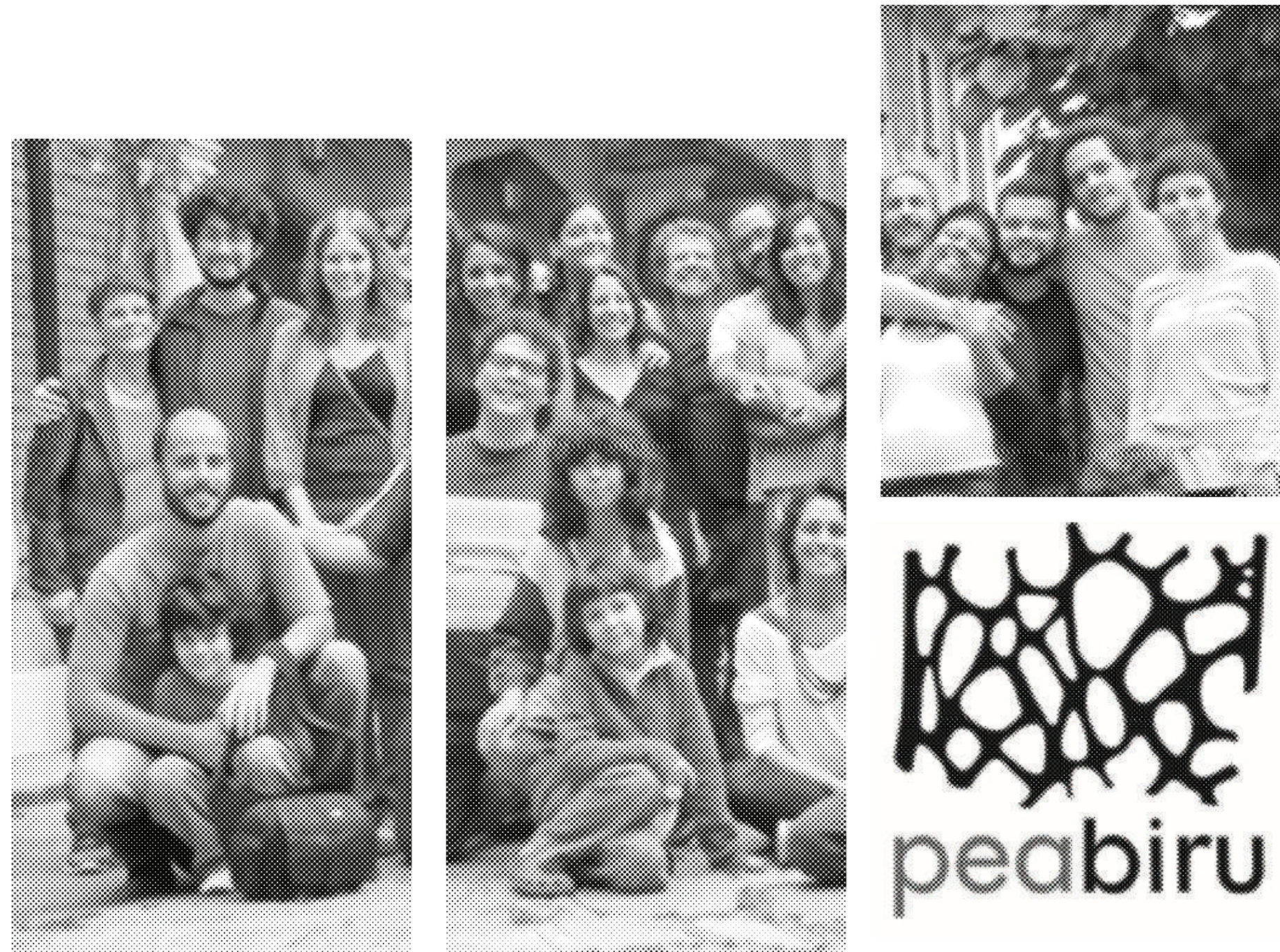

\section{PEABIRU TCA (TRABALHOS COMUNITÁRIOS E AMBIENTAIS)}

Data de Formação: 1993

Sobre: é uma ONG de Assessoria Técnica, fundada em 1993 por um grupo de técnicos multidisciplinares que tinham experiência em assessorias técnicas sobretudo na produção habitacional de interesse social no período antecessor à sua formação. A Peabiru tem mais de 20 anos de atuação em produção habitacional autogestionária e urbanizações de favelas e assentamentos precários.

Desde a sua formação a Peabiru trabalha buscando a interdisciplinariedade, a troca de saberes com os grupos assessorados e a atuação no campo da luta pela moradia digna e pelo direito à cidade.

Hoje a Peabiru organiza o seu trabalho em 3 programas: Produção do Espaço, Crítica e Política.

www.peabirutca.org.br. 


\section{EXPERIÊNCIAS RELEVANTES COM FAVELAS}

\section{1-2016}

Planejamento / Projeto / Outros

Urbanização Integrada Batistini, São Bernardo do Campo - SP

VER FICHA DE PROJETO em Cap.2

\section{6}

Acadêmica

II UrbFavelas, Seminário Nacional de Urbanização de Favelas, UFABC, Rio de Janeiro - RJ

Agente Organizador: IPPUR - UERJ

Breve descrição: participação no seminário com a apresentação de artigos

\section{6}

Acadêmica / Outros

OfICINAS ATHIS - Ribeirão Preto, Santos, São José dos Campos, Bauru, Campinas,

São Paulo - SP

Agente Organizador: Peabiru TCA

Agente Contratante: patrocínio CAU SP

Breve descrição: as Oficinas ATHIS foram organizadas pela Peabiru de forma a fomentar o debate sobre as dimensões das necessidades habitacionais e sobre a participação dos profissionais da arquitetura, engenharia, das áreas sociais e do direito nos processos de produção habitacional para a população de baixa renda, seja ela promovida por programas públicos, seja por autoconstrução ou autoempreendimento.

Através de Oficinas teóricas e práticas sobre realidades de habitação precária, inclusive favelas, e a participação de diversos agentes, inclusive moradores, a Peabiru tentou promover o exercício de arranjos institucionais e produtivos que viabilizassem a assistência técnica em diferentes locais e realidade.

Observações: a partir dessa experiência, a Peabiru tem procurado apoiar grupos interessados em desenvolver assessoria técnica nessas cidades. Durante o ano de 2017, a Peabiru está desenvolvendo um filme, também com o patrocínio do CAU-SP, para divulgar a prática da Assessoria Técnica em Arquitetura e Urbanismo.

\section{1 e 2015}

Planejamento / Projeto

Capelinha e Cocaia, São Bernardo do Campo - SP

VER FICHA DE PROJETO em Cap.2

\section{4}

Acadêmica

I UrbFavelas, Seminário Nacional de Urbanização de Favelas, UFABC, São Bernardo do Campo - SP

Agente Organizador: UFABC

Breve descrição: participação no seminário em mesas redondas, com a apresentação de artigos, e pôsteres em exposição de Projetos de Urbanização de Favelas. 


\section{2-2013}

Planejamento / Projeto / Outros

Plano Popular Alternativo para a Comunidade da Paz, São Paulo - SP

Agente Organizador: Comunidades Unidas do Itaquera

Parceiros: Instituto Pólis e Comunidades Unidas do Itaquera

Escopo: realização de levantamentos em fontes secundárias, oficinas e reuniões com moradores e lideranças e elaboração de Plano Urbanístico em documento tipo livreto, com possibilidades de intervenção

Breve descrição: Assessoria Técnica ao processo de elaboração de um Plano Alternativo Popular organizado pelos moradores da Favela da Paz em Itaquera, Zona Leste de São Paulo. A comunidade é composta por 300 famílias, e está situada a $1 \mathrm{~km}$ do Estádio do Corinthians em Itaquera, construído para a Copa do Mundo de 2014 e estava ameaçada de remoção por conta de obras do Parque Linear, de infraestrutura e novos equipamentos públicos do entorno do estádio. A partir de levantamentos que constataram a existência de terrenos vazios e grande oferta de equipamentos públicos e infraestrutura urbana no bairro, construiu-se um conjunto de diretrizes pelos moradores, para o enfrentamento para a permanência no mesmo local que a favela ocupa ou em terrenos próximos a este.

Observações: o Plano serviu à comunidade como uma forma de organização da luta pela permanência e por um atendimento habitacional adequado. Dois conjuntos habitacionais localizados nas proximidades da favela foram destinados ao atendimento das famílias, que só foram removidas depois que a moradia definitiva estiver pronta, e foram realizadas obras emergenciais na própria favela, incluindo urbanização da margem do Rio Verde.

\section{1-2012}

Gestão / Planejamento

Plano de Gestão Socioambiental Sustentável Billings Pós-Balsa, São Bernardo do

Campo - SP

Agente Organizador: Prefeitura de São Bernardo do Campo

Agente Contratante: Forti Consultoria (contratados da Prefeitura)

Escopo: vistorias, oficinas, apoio à elaboração do Plano, particularmente nos temas de habitação e urbanismo.

Breve descrição: diagnóstico e plano urbanístico e habitacional para uma área APRMBillings no município de São Bernardo do Campo, que é acessada pelas balsas da EMAE na represa Billings. $O$ trabalho incluiu acompanhamento de algumas atividades promovidas pela consultoria contratada pela Prefeitura (oficina de mapas mentais com agentes comunitários de saúde, oficinas e reuniões com técnicos das secretarias municipais), vistorias aos núcleos habitacionais existentes na região, visando a uma caracterização geral com estimativa de atendimento habitacional por obras de urbanização que embasaram a demarcação de áreas que foram gravadas como ZEIS no Plano Diretor de São Bernardo do Campo.

2011

Planejamento / Projeto / Outros

Concurso Renova SP, São Paulo - SP

Agente Organizador: Sehab, Prefeitura de São Paulo e IAB-SP

Escopo: Concurso público de projeto de urbanização, regularização de favelas e loteamentos precários

Breve descrição: elaboração de propostas para urbanização e regularização de favelas e loteamentos precários, inseridos em Perímetros de Ação Integrada (PAI), que, por sua vez são baseados em Sub-bacias hidrográficas. A Peabiru participou apresentando propostas para os perímetros Pirajussara 5 e Pirajussara 7, enfocando o atendimento integral das famílias removidas no próprio perímetro e uma urbanização que integrasse as favelas em loteamentos ao bairro, inclusive com o estabelecimento de instâncias de participação e controle social. O concurso previa ainda apresentação de propostas de conjuntos habitacionais em terrenos vazios (na Zona Leste, Zona Sul e Zona Norte).

Observações: A proposta da Peabiru não foi premiada. 
2010

Planejamento / Projeto / Outros

Concurso Morar Carioca, Rio de Janeiro - RJ

Agente Organizador: Prefeitura do Rio de Janeiro e IAB-RJ

Escopo: concurso público de metodologias para intervenção em assentamentos precários e Desenvolvimento de projetos de Urbanização de Favelas

Breve descrição: concurso público de metodologias para intervenção em favelas e assentamentos precários, visando a seleção de 40 equipes interdisciplinares que seriam contratadas para desenvolver projetos para favelas do município do Rio de Janeiro, para cumprir a meta de urbanizar todas as favelas até 2020. Embora o concurso previsse que as equipes apresentassem propostas para favelas de encosta, planície e complexos de favelas, a Peabiru optou por apresentar um processo de trabalho como estruturante da metodologia, abordando os eixos habitat (fisico-urbanístico), convívio (social e organizativo) e dominialidade (jurídico). Dos levantamentos iniciais ao pós-obra, incorporava-se a consulta e participação da população no sentido de validar as proposições, visando um compartilhamento das técnicas no processo de projeto e urbanização.

Observações: a Peabiru foi uma das equipes selecionadas e foi contratada no fim de 2013 para desenvolver os projetos completos para o Agrupamento Costa Barros, na Zona Norte do município, composto por seis núcleos que totalizam 1900 famílias. Depois de mais de um ano sem ordem de início dos serviços, o contrato foi cancelado.

\section{7-2010}

Planejamento / Projeto / Outros

Urbanização da favela do Morro do Sabão, Taboão da Serra -SP

Agente Organizador: Prefeitura Municipal de Taboão da Serra

Agente Contratante: Prefeitura Municipal de Taboão da Serra

Escopo: elaboração e coordenação de projetos urbanísticos e de edificação (habitação e equipamento comunitário) completos para urbanização do núcleo habitacional.

Breve descrição: para atender a uma urgência da prefeitura para apresentação de projetos ao Ministério das Cidades para captação de recursos, a Peabiru desenvolveu, em cerca de vinte dias, uma proposta em nível preliminar para essa favela localizada em área configurada como um anfiteatro natural. A urgência e algumas poucas visitas de reconhecimento só permitiam um olhar genérico para o problema e a tal definição de grandes setores, de modo que o critério básico foi determinar uma espécie de anel de consolidação, com domicílios voltados às rua externas ou a vielas mais estruturadas, e um miolo de remoção, que incluía áreas de risco por altas declividades ou pela proximidade ao curso d'água. Observações: depois da primeira proposta, a Peabiru realizou levantamentos físicos em todas as moradias e desenvolveu uma primeira proposta de Índice de Precariedade Habitacional (IPHAB) que embasaram uma revisão do projeto de intervenção, incluindo projetos urbanísticos e habitacionais.

\section{7-2009}

Planejamento / Projeto / Outros

Regularização Fundiária Jd. Imperador, São Paulo - SP

Agente Organizador: Associação de Moradores (Associação Amigos do Estado do Amazonas/Inhumas)

Agente Contratante: Associação Amigos do Estado do Amazonas/Inhumas

Escopo: coordenação de levantamento planialtimétrico, relatórios, elaboração de projeto de regularização fundiária, assessoria técnica à associação de moradores em reuniões com técnicos da prefeitura, levantamentos socioeconômicos simplificados, reuniões com moradores.

Breve descrição: o trabalho incluiu a realização de levantamentos planialtimétricos e a realização de proposta para regularização técnica fundiária (com relatórios e propostas de parcelamento) até a obtenção do auto de regularização técnica emitido pela Prefeitura de São Paulo. Foram realizados também levantamentos socioeconômicos simplificados junto aos moradores, incluindo reuniões gerais para apresentação da proposta. 


\section{5 - 2008}

Planejamento / Projeto / Outros

Estudo para a Regularização Fundiária dos assentamentos: favela Amadeu, Jd. Guapira, Heliópolis, São Paulo - SP

Agente Organizador: Instituto Pólis

Agente Contratante: Instituto Pólis

Escopo: consultoria em arquitetura e urbanismo ao Instituto Pólis no projeto de Regularização Fundiária em São Paulo.

Breve descrição: a Peabiru apoiou a elaboração do instrumental e participou ativamente dos levantamentos e das definições de estratégias que pretendiam cobrir as três dimensões definidas nos manuais do Ministério das Cidades como estruturantes da Regularização Fundiária: jurídica, social e urbanística-habitacional. Deteve-se, naturalmente, mais nos aspectos físicos, urbanísticos e habitacionais.

\section{5-2007}

Planejamento / Projeto / Outros

Favela Irati, Taboão da Serra -SP

Agente Organizador: Prefeitura Municipal de Taboão da Serra

Agente Contratante: Prefeitura Municipal de Taboão da Serra

Escopo: projeto urbanístico e de provisão habitacional no próprio assentamento

Breve descrição: revisão do projeto elaborado no contexto do Programa Habitar Brasil $B I D$, reconhecido por lidar com as favelas a partir de intervenções mínimas, sem mudar a estrutura urbana do assentamento. No processo, a Peabiru apropriou-se de levantamentos e ações que a prefeitura já vinha desenvolvendo, como a remoção de domicílios pelas condições construtivas ou uma identificação de risco promovida pela Defesa Civil, e demarcou, não grandes áreas, mas cada domicílio a partir do impacto dessas ações e das ações pretendidas pelo novo projeto: remoção para abertura de via interna e para liberação de área para provisão habitacional no núcleo.

\section{3}

Planejamento / Projeto

Parque do Gato, São Paulo - SP

Agente Organizador: Cohab-SP, Prefeitura Municipal de São Paulo

Agente Contratante: Cohab-SP, Prefeitura Municipal de São Paulo

Escopo: revisão de estudos preliminares realizados pela $\mathrm{COHAB}-\mathrm{SP}$ e desenvolvimento de projetos básicos e executivos completos (edificação, urbanismo, infra-estrutura pública e condominial e projetos para aprovação legal) de conjunto verticalizado com 486 unidades, divididas em 4 condomínios, áreas públicas de lazer e equipamentos (centro comercial e creche), para além da coordenação de estudos complementares.

Breve descrição: o Parque do Gato foi um projeto urbano que contemplou a produção de HIS para a realocação das famílias removidas da Favela do Gato, que se encontrava na borda do rio Tietê em área de risco.

\section{$2000-2003$}

Planejamento / Projeto / Obra / Trabalho Social

Tamarutaca, Santo André -SP

Agente Organizador: Programa Integrado de Inclusão Social / Santo André Mais Igual, Prefeitura de Santo André

Agente Contratante: Programa Integrado de Inclusão Social / Santo André Mais Igual, Prefeitura de Santo André / Unidade de Gestão da União Europeia

Escopo: Assessoria técnica à urbanização (desenvolvimento de projetos de infraestrutura e viabilização de frentes de obra de infraestrutura e parcelamento) e autoconstrução (discussão, desenvolvimento de projetos e acompanhamento das obras) no núcleo.

Breve descrição: a equipe da Peabiru atuava junto ao Departamento de Habitação, no trabalho mais direto com a população para urbanização e construção das habitações. Apoiava a liberação das frentes de obra de urbanização (escadarias, sistema viário e redes de infraestrutura), apoiando a gestão das realocações para casas de familiares ou para o alojamento provisório; no reparcelamento do assentamento, definição de critérios para reocupação juntamente com as famílias; elaboração dos projetos das moradias que seriam executadas em regime de autoconstrução/autoempreendimento; e, por fim, acompanhamento técnico das obras. No último ano e meio de atuação da Peabiru, foram realizadas também algumas melhorias habitacionais envolvendo as moradias já consolidadas do assentamento. 
Planejamento / Projeto / Outros

Favela Raul Seixas, Itaquera, São Paulo - SP

Breve descrição: acompanhamento técnico e social de famílias da favela com vistas a organização para discussão e reivindicação de urbanização do núcleo habitacional.

\section{1}

Planejamento / Projeto / Outros

Eng. Goulart / Favela da Caixa D'água, São Paulo - SP

Breve descrição: estudo de viabilidade e articulação das partes envolvidas (movimento popular, associação de moradores, órgãos da prefeitura de São Paulo, incorporadora e proprietário) para urbanização e construção de habitações verticalizadas.

1999

Projeto

Estudos para quadra esportiva e edifício destinado a creche, na favela de Heliópolis,

São Paulo - SP

Breve descrição: desenvolvimento de estudos para quadra esportiva e edifício destinado a creche, na favela de Heliópolis (em parceria com Piratininga Arquitetos).

\section{8 - 1999}

Acadêmica

Faz Tudo na Comunidade I e II, Favela Heliópolis, São Paulo - SP

Agente Organizador: UNAS (União dos Núcleos Associações e Sociedades de Heliópolis e São João Clímaco),

Agente Contratante: UNAS e Programa Capacitação Solidária do governo federal Breve descrição: curso de capacitação profissional em construção civil para jovens de 15 a 20 anos de idade. O curso tomava a construção de uma moradia nova como objeto didático para capacitação dos jovens. A associação local selecionava uma famílias que viviam em casas muito precárias (barraco de madeira), viabilizava uma moradia provisória alugada na própria favela durante o período do curso, para que a demolição do barraco, desenvolvimento dos projetos (com aproximação aos elementos e interpretação de desenhos técnicos), construção integral da nova moradia (fundações, estrutura, alvenaria, instalações elétricas e hidráulicas). 

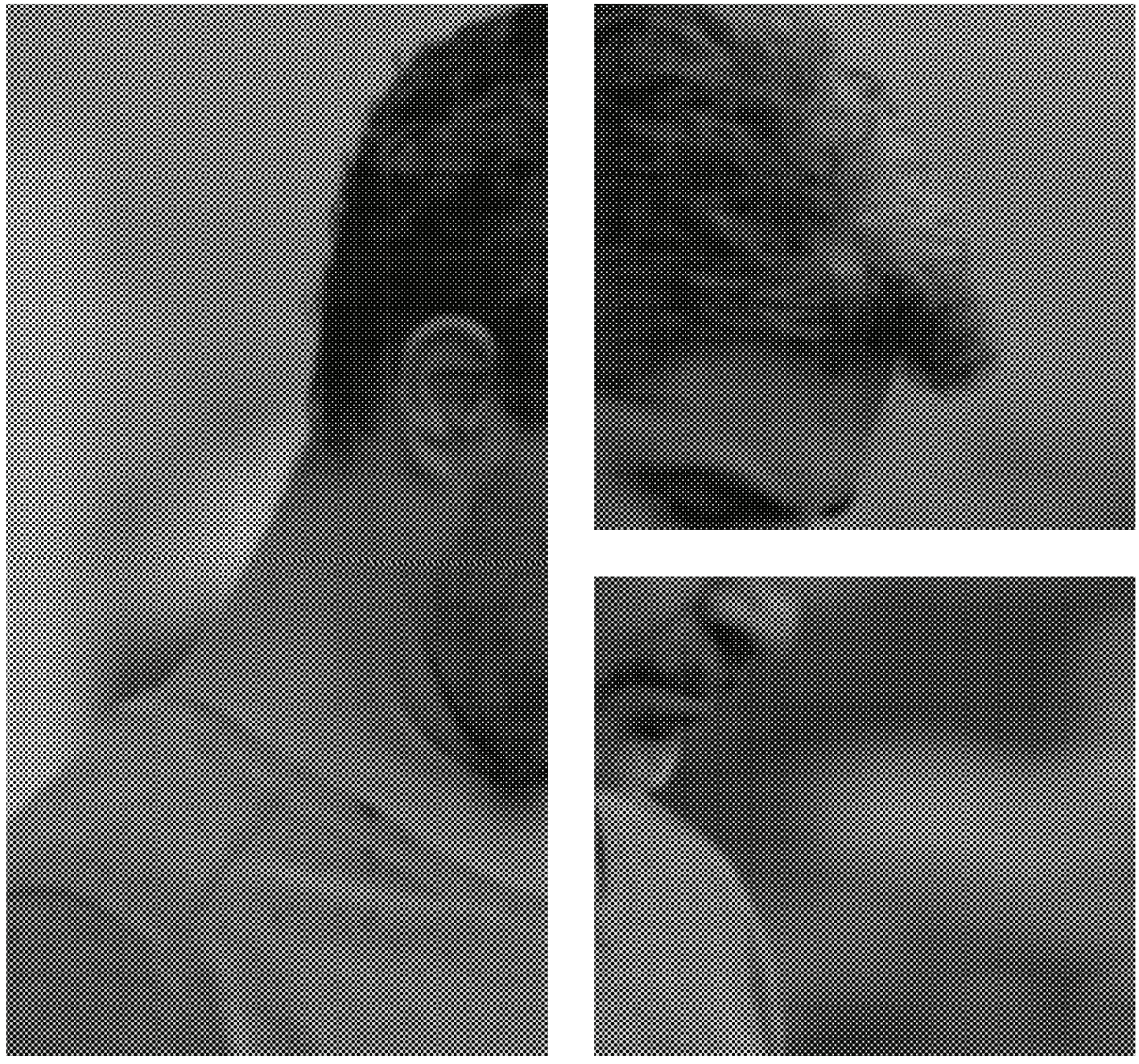

CAIO SANTO AMORE DE CARVALHO (1974)

\section{Formação} 2008-2013

Doutorado em Arquitetura e Urbanismo, FAUUSP, Brasil

Título: Entre o nó e o fato consumado, o lugar dos pobres da cidade: um estudo sobre as ZEIS e os impasses da Reforma Urbana na atualidade.

Orientador: João Sette Whitaker Ferreira.

\section{0-2004}

Mestrado em Arquitetura e Urbanismo, FAUUSP, Brasil

Título: Lupa e telescópio: o mutirão em foco - São Paulo, anos 90 e atualidade. Orientador: Maria Ruth Amaral de Sampaio.

\section{2 - 1997}

Graduação Faculdade de Arquitetura e Urbanismo da Universidade de São Paulo FAUUSP, Brasil 


\section{OUTRAS EXPERIÊNCIAS RELEVANTES EXPERIÊNCIAS RELEVANTES COM FAVELAS}

\section{8 - atual \\ Gestão / Planejamento / Projeto \\ Peabiru TCA}

Função: arquiteto e urbanista, membro.

\section{1-2016}

Planejamento / Projeto / Outros Urbanização Integrada Batistini, São Bernardo do Campo - SP

Função: acompanhamento do trabalho. VER FICHA DE PROJETO em Cap.2

\section{6}

Acadêmica

II UrbFavelas, Seminário Nacional de Urbanização de Favelas, UFABC, Rio de Janeiro - RJ

Função: participante no seminário e co-autor dos trabalhos apresentados.

\section{5-2016}

Acadêmica / Outros

OFICINAS ATHIS - Ribeirão Preto, Santos, São José dos Campos, Bauru, Campinas, São Paulo - SP

Função: organizador, monitor e palestrante.

\section{1- 2015}

Planejamento / Projeto

Capelinha e Cocaia, São Bernardo do Campo - SP

2014 - atual

Acadêmica Função: acompanhamento do trabalho.

FAUUSP, Brasil

Função: docente no curso de Arquitetura

e Urbanismo, Graduação e

Pós-Graduação, orientador de pesquisas de Iniciação Científica e de Projetos de Extensão Universitária.

2012 - 2014

Acadêmica

Universidade Anhembi Morumbi, UAM,

Brasil

Função: docente em Arquitetura e Urbanismo. Graduação e orientação de Extensão Universitária e Escritório Modelo.

2005 - 2012

Acadêmica

Centro Universitário de Araras Dr Edmundo Ulson, UNAR, Brasil

Função: docente em Arquitetura e Urbanismo. Graduação.
VER FICHA DE PROJETO em Cap.2

\section{4}

Acadêmica

I UrbFavelas, Seminário Nacional de Urbanização de Favelas, UFABC, São Bernardo do Campo - SP Data: 2014 Função: participante no seminário, co-autor dos trabalhos apresentados e integrante em mesas de discussão.

\section{2-2013}

Planejamento / Projeto / Outros Plano Popular Alternativo para a Comunidade da Paz, São Paulo - SP

Função: arquiteto e urbanista.

\section{1-2012}

Gestão / Planejamento

Plano de Gestão Socioambiental Sustentável Billings Pós-Balsa, São Bernardo do Campo - SP

Função: arquiteto e urbanista, coordenação da equipe técnica. 


\section{OUTRAS EXPERIÊNCIAS RELEVANTES}

2009 - 2011

Planejamento / Projeto

Diagonal Urbana Consultoria, Brasil

Função: colaborador, arquiteto e

urbanista

Breve descrição: participação na equipe de projeto da gerência que mantinha contrato com a Fundação Vale, visando apoio aos municípios e territórios atingidos pela operação da mineradora nos estados do Pará, Maranhão, Minas Gerais e Espírito Santo.
EXPERIÊNCIAS RELEVANTES COM FAVELAS

\section{1}

Planejamento / Projeto / Outros Concurso Renova SP, São Paulo - SP Função: arquiteto e urbanista, coordenação da equipe técnica.

\section{0}

Planejamento / Projeto / Outros

Concurso Morar Carioca, Rio de Janeiro - RJ

Função: arquiteto e urbanista, coordenação da equipe técnica.

\section{7-2010}

Planejamento / Projeto / Outros Urbanização da favela do Morro do Sabão, Taboão da Serra -SP

Função: arquiteto e urbanista.

\section{7-2009}

Planejamento / Projeto / Outros Regularização Fundiária Jd. Imperador, São Paulo - SP

Função: arquiteto e urbanista.

2005 - 2008

Planejamento / Projeto / Outros Estudo para a Regularização Fundiária dos assentamentos: favela Amadeu, Jd. Guapira, Heliópolis, São Paulo - SP Função: arquiteto e urbanista.

\section{5-2007}

Planejamento / Projeto / Outros Favela Irati, Taboão da Serra -SP Função: arquiteto e urbanista.

\section{3}

Planejamento / Projeto Parque do Gato, São Paulo - SP Função: arquiteto e urbanista.

\section{$2000-2003$}

Planejamento / Projeto / Obra / Trabalho Social

Tamarutaca, Santo André - SP

Função: arquiteto e urbanista, acompanhamento de obra.

VER FICHA DE PROJETO em Cap.2

2001

Planejamento / Projeto / Outros Favela Raul Seixas, Itaquera, São Paulo - SP

Função: arquiteto e urbanista. 


\section{OUTRAS EXPERIÊNCIAS RELEVANTES EXPERIÊNCIAS RELEVANTES COM FAVELAS}

$1997-1998 \quad 2001$

Planejamento / Projeto

Peabiru TCA

Função: estagiário em arquitetura e

urbanismo

Planejamento / Projeto / Outros

Eng. Goulart / Favela da Caixa D'água,

São Paulo - SP

Função: arquiteto e urbanista.

1999

Projeto

Estudos para quadra esportiva e edifício destinado a creche, na favela de Heliópolis, São Paulo - SP

Função: arquiteto e urbanista.

1998 - 1999

Tipo: Acadêmica

Faz Tudo na Comunidade I e II, Favela Heliópolis, São Paulo - SP

Função: arquiteto e urbanista, formador. 


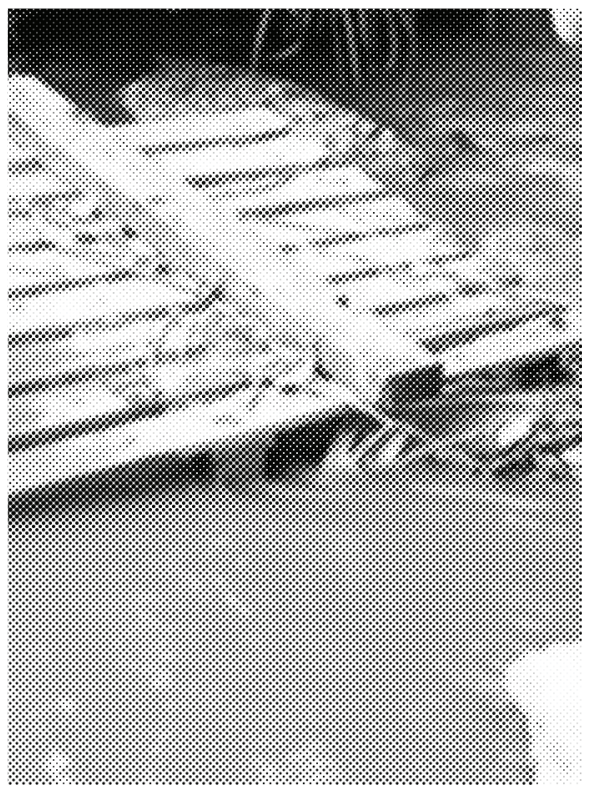

ALEXANDRE HODAPP OLIVEIRA MARQUES (1971)

Formação

1991 - 1997

Graduação Faculdade de Arquitetura e Urbanismo da Universidade de São

Paulo - FAUUSP, Brasil

Formação Complementar relevante para experiência com favelas

2014

Oficina Autogestão em Habitação UMM

2011

Oficina Latino-americana de Assessorias Técnicas - Fórum AT

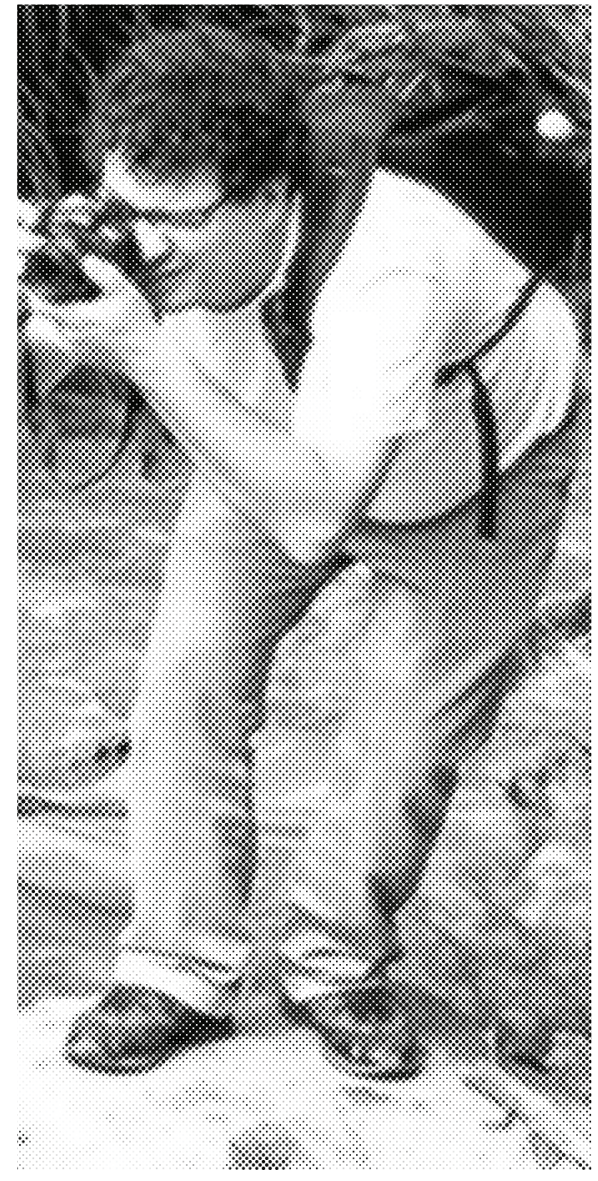




\section{OUTRAS EXPERIÊNCIAS RELEVANTES EXPERIÊNCIAS RELEVANTES COM FAVELAS}

\author{
2010 - atual \\ Gestão / Planejamento / Projeto \\ Peabiru TCA
}

Função: arquiteto e urbanista, membro.

2013-2015

Gestão / Planejamento / Projeto

Celso Sampaio Arquitetura

Função: arquiteto e urbanista.

Breve descrição: participou da

Regularização fundiária do loteamento Jardim dos Oliveira, Guarulhos e Projeto do Parque Central do Itaim Paulista SVMA, São Paulo.

2008-2009

Planejamento / Projeto

Diagonal Urbana Consultoria, Brasil

Função: colaborador, arquiteto e urbanista.

Breve descrição: estudos para conjuntos habitacionais horizontais a serem construídos pelo PMCMV em municípios com a presença da mineradora Vale.

2002-2006

Gestão / Planejamento / Projeto

COHAB-SP (Cia. Metropolitana de Habitação de São Paulo)

Função: assessor de superintendência - gestor de contratos de projeto do programa Morar no Centro.

Breve descrição: acompanhamento como assessor dos projetos do programa Morar no Centro. Gestão dos projetos Riachuelo, Prestes Maia, Metrô Belêm, Bresser XIV, José Bonifácio, Casarão do Carmo. Acompanhamento das obras do edifício Riachuelo. Concepção e desenvolvimento do projeto São Caetano.

\section{1 - 2016}

Planejamento / Projeto / Outros

Urbanização Integrada Batistini, São Bernardo do Campo - SP

Função: arquiteto e urbanista, elaboração e coordenação de projetos urbanísticos e social.

VER FICHA DE PROJETO em Cap.2

\section{1- 2015}

Planejamento / Projeto

Capelinha e Cocaia, São Bernardo do

Campo - SP

Função: arquiteto e urbanista.

VER FICHA DE PROJETO em Cap.2

\section{5 - 2012}

Acadêmica

Função: palestrante em Semanas de Arquitetura ou em disciplinas nas seguintes faculdades de arquitetura e urbanismo sobre urbanização de favelas, habitação social e assessoria técnica.

\section{4}

Acadêmica

I UrbFavelas, Seminário Nacional de Urbanização de Favelas, UFABC, São Bernardo do Campo - SP Data: 2014 Função: participante no seminário, $c o$ -autor dos trabalhos apresentados. 

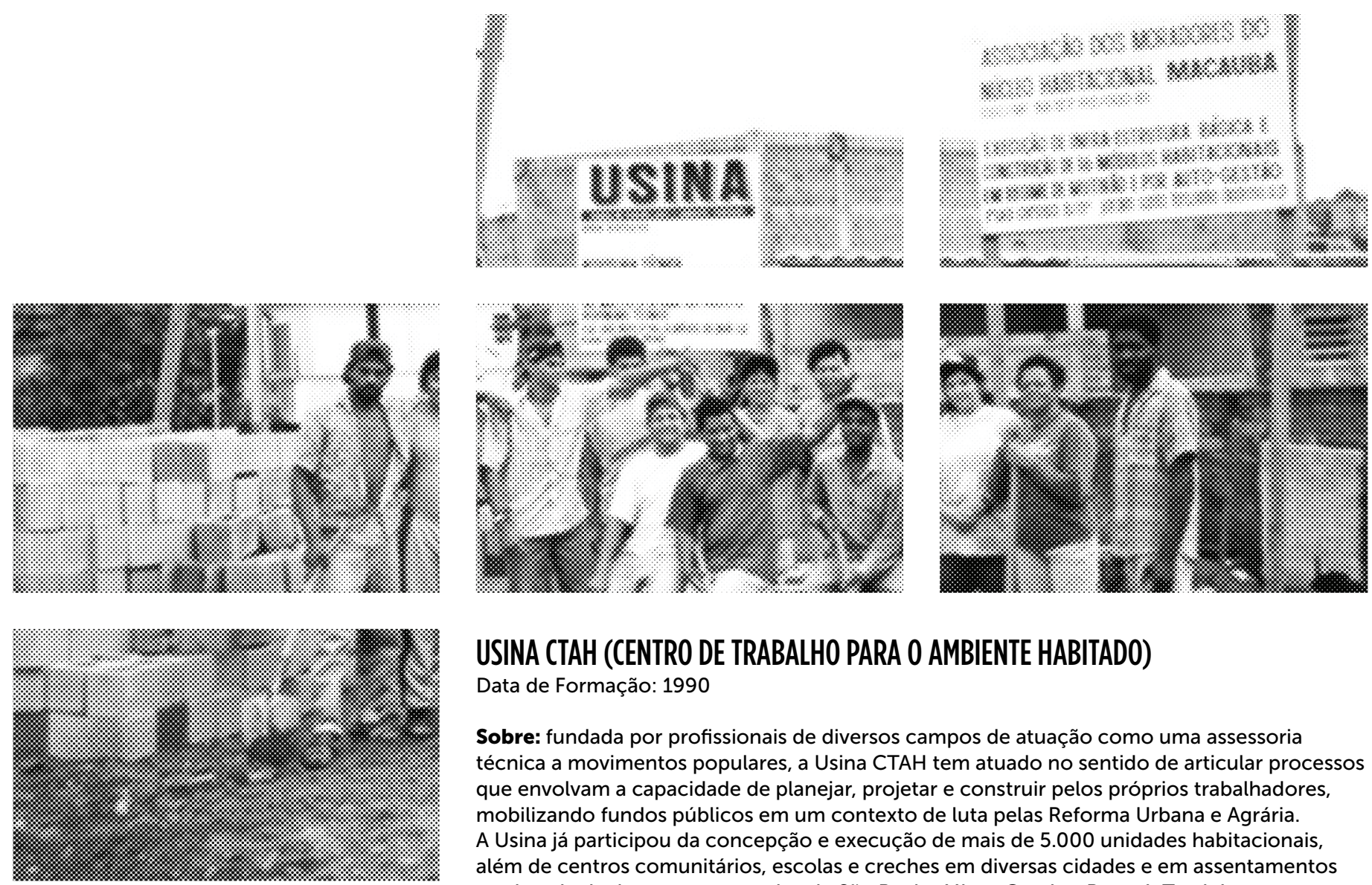

\section{USINA CTAH (CENTRO DE TRABALHO PARA O AMBIENTE HABITADO)}

Data de Formação: 1990

Sobre: fundada por profissionais de diversos campos de atuação como uma assessoria técnica a movimentos populares, a Usina CTAH tem atuado no sentido de articular processos que envolvam a capacidade de planejar, projetar e construir pelos próprios trabalhadores, mobilizando fundos públicos em um contexto de luta pelas Reforma Urbana e Agrária. A Usina já participou da concepção e execução de mais de 5.000 unidades habitacionais, além de centros comunitários, escolas e creches em diversas cidades e em assentamentos rurais, principalmente nos estados de São Paulo, Minas Gerais e Paraná. Também atuou no desenvolvimento de planos urbanísticos, projetos de urbanização de favelas e auxiliou a formação e organização de cooperativas de trabalho. Nos últimos anos ampliou sua atuação também para o campo das artes visuais e educação popular ligados direta e indiretamente aos trabalhos de concepção e construção do espaço habitado.

A equipe da assessoria tem intenção de superar a produção autoral e estritamente comercial da arquitetura e do urbanismo e busca, para tanto, integrar e engendrar processos alternativos à lógica do capital através de experiências sociais, espaciais, técnicas e estéticas contra-hegemônicas.

www.usina-ctah.org.br 


\section{EXPERIÊNCIAS RELEVANTES COM FAVELAS}

2008 - 2010

Planejamento

Plano Local de Habitação de Interesse Social (PLHIS) de Diadema, SP

Agente Organizador: Secretaria de Habitação e Desenvolvimento Urbano do Município de Diadema

Agente Contratante: Secretaria de Habitação e Desenvolvimento Urbano do Município de Diadema e Sistema Nacional de Habitação de Interesse Social

Escopo: realização de oficinas com os moradores e lideranças, Elaboração de diagnóstico da situação habitacional do município; Definição de princípios, objetivos e diretrizes; Articulação entre a estrutura de gestão, os programas e as ações; Definição de ações e metas até o ano de 2020; Definição e articulação dos quatro programas do município: Programa de Urbanização de Núcleos Habitacionais; Programa de Provisão Habitacional; Programa de Requalificação Habitacional e Programa de Regularização Fundiária.

Breve descrição: o Plano Local de Habitação de Interesse Social (PLHIS) de Diadema teve como objetivo realizar um balanço da realidade habitacional do município e da história de sua política urbana e habitacional, para assim estabelecer princípios, diretrizes e estratégias no planejamento de ações de curto, médio e longo prazos.

$2002-2003$

Planejamento / Outros

Plano Cidade Tiradentes, São Paulo, SP

Agente Organizador: Prefeitura do Município de São Paulo - SEHAB.

Agente Contratante: Prefeitura do Município de São Paulo - SEHAB, Cities Alliance - Programa Bairro Legal.

Escopo: realização de oficinas com os moradores e lideranças, pré-diagnóstico físico-social-ambiental, elaboração do Plano Habitacional Urbano.

Breve descrição o Plano Habitacional Urbano de Cidade Tiradentes visava desenvolver, com a participação dos moradores do bairro, um plano de ação que pudesse qualificar a área ocupada por conjuntos habitacionais (a maior concentração da América Latina), loteamentos irregulares e favelas em seus interstícios. Buscou-se identificar e operar temas urbanos a partir da relação horizontal entre as secretarias municipais, a participação popular e a concepção técnica e política dos profissionais envolvidos. Foi desenvolvido em etapas, partindo de diversos diagnósticos até chegar ao plano final, indicando ações urbanísticas em identidade às ações sociais e administrativas, concentrando-se em situações especiais que pudessem efetivamente ser uma inflexão no processo vigente de produção do espaço.

1999

Planejamento / Projeto

Estudo de viabilidade técnica e econômica para intervenção em 3 áreas, Santo André - SP

Agente Organizador: Prefeitura do Município de Santo André.

Agente Contratante: Prefeitura do Município de Santo André.

Breve descrição: desenvolvimento de estudo de viabilidade técnica e econômica para implantação do Programa Habitar Brasil/BID em três áreas.

1993 - 1997

Planejamento / Projeto

Vila Senhor dos Passos, Belo Horizonte - MG

Agente Organizador: Projeto Alvorada e Prefeitura de Belo Horizonte - Urbel (Cia. Urbanizadora de Belo Horizonte).

Agente Contratante: Prefeitura de Belo Horizonte - Urbel, convênio com a Sociedade Mineira de Cultura e com a AVSI (entidade italiana de fomento ao desenvolvimento).

Escopo: projeto de arquitetura, urbanismo e infraestrutura para urbanização da favela e realocação das famílias em 6 edifícios.

Breve descrição: elaboração de projetos de urbanísticos e edificação verticalizada para reassentamento de 174 famílias em 07 áreas totalizando aproximadamente $9.500 \mathrm{~m} 2$. 
1994 - 1995

Planejamento / Projeto

Urbanização da Vila Popular, Diadema - SP

VER FICHA DE PROJETO em Cap.2

\section{3 - 1995}

Planejamento / Projeto

Urbanização Favela Macaúba, Diadema - SP

Agente Organizador: Associação dos Moradores do Núcleo Habitacional Macaúba. Agente Contratante: Prefeitura Municipal de Diadema.

Escopo: assessoria técnica, projeto de arquitetura, urbanismo e infraestrutura para urbanização da favela, implantação de 16 unidades habitacionais e acompanhamento de obras em mutirão.

Breve descrição: o projeto de urbanização da Favela da Macaúba consistiu no redesenho dos lotes da favela através de processo participativo, relocação das famílias envolvidas e construção através de mutirão somente da estrutura das casas, com blocos de concreto e laje pré-moldada, para posterior fechamento em alvenaria pelas próprias famílias.

\section{4}

Planejamento / Projeto

Urbanização Favela Carapeba, Diadema - SP

Agente Organizador: Departamento de Planejamento Habitacional da Prefeitura Municipal de Diadema

Agente Contratante: Prefeitura Municipal de Diadema.

Escopo: elaboração de projeto de urbanização e prestação de serviços de assessoria técnica para execução dos serviços de urbanização da favela.

\section{0}

Planejamento / Projeto

Estudo preliminar para implantação de um Parque Metropolitano em Nova Iguaçu - RJ

Agente Organizador: Secretaria de Assuntos Fundiários e Assentamentos Humanos do Estado do Rio de Janeiro.

Agente Contratante: Secretaria de Assuntos Fundiários e Assentamentos Humanos do Estado do Rio de Janeiro.

Escopo: elaboração de estudo preliminar para implantação de um Parque Metropolitano em Nova Iguaçu, em área de $850.000 \mathrm{~m}$. 

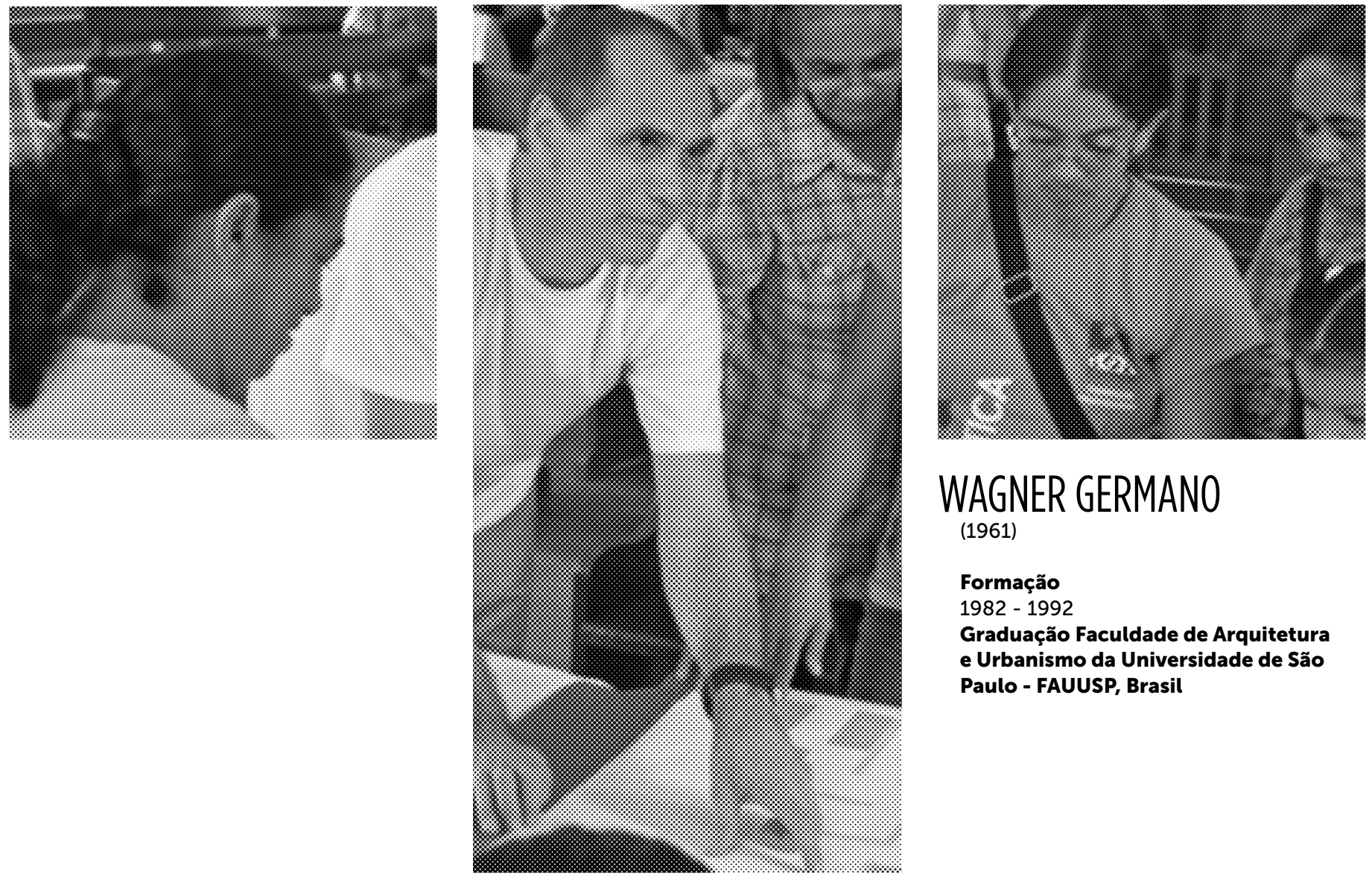

\section{WAGNER GERMANO}

(1961)

Formação

1982 - 1992

Graduação Faculdade de Arquitetura

e Urbanismo da Universidade de São

Paulo - FAUUSP, Brasil 


\section{OUTRAS EXPERIÊNCIAS RELEVANTES EXPERIÊNCIAS RELEVANTES COM FAVELAS}

\section{0 - atual \\ Gestão / Planejamento / Projeto \\ USINA CTAH}

Função: membro-fundador, arquiteto e urbanista.

$2004-2005$

Acadêmica

Universidade do Grande ABC, Santo

André, Brasil

Função: docente da disciplina de Projeto Arquitetônico II, III e VII e Orientador de Trabalho de Graduação Interdisciplinar.

2001-2005

Gestão

COHAB-SP (Companhia Metropolitana de Habitação do Município de São

Paulo)

Função: Superintendente de Planejamento e Projeto e Assessor de Diretoria.

$2000-2004$

Acadêmica

Universidade Santa Cecília, Santos,

Brasil

Função: docente da disciplina de Projeto Arquitetônico IV e como Orientador de Trabalho de Graduação Interdisciplinar.

\section{1 - 2004}

Gestão / Planejamento

Plano Urbanístico para a favela

Heliópolis (estudo), São Paulo, SP

Agente Organizador: Cohab-SP / SEHAB

-SP.

Agente Contratante: Prefeitura Municipal de São Paulo.

Função: Gestor, Arquiteto e Urbanista

[CoHab-SP].

Breve descrição: elaboração de estudos de viabilidade, para a reurbanização de Heliópolis.

Observações: tanto o estudo como a iniciativa da Cohab-SP / SEHAB-SP não foram a diante.

\section{3}

Gestão / Planejamento

Parque do Gato, São Paulo - SP

Agente Organizador: Cohab-SP

Agente Contratante: Cohab-SP, Prefeitura Municipal de São Paulo

Função: Gestor, Arquiteto e Urbanista, responsável pelo projeto urbano de realocação das famílias e restante área abrangente [CoHab-SP]

Breve descrição: O Parque do Gato foi um projeto urbano que contemplou a produção de HIS para a realocação das famílias removidas da Favela do Gato, no âmbito do programa de locação social, que se encontrava na margem do rio Tamanduateí, considerado área de risco. O projeto contemplava a construção de 486 unidades, áreas públicas de lazer e equipamentos.

Observações: $O$ desenvolvimento dos projetos básicos e executivos foi da Peabiru TCA.
1996 - 2000

Acadêmica

Departamento de Arquitetura da Universidade de Taubaté, Taubaté, Brasil

Função: professor colaborador e

Assistente vinculado a disciplina de

Projetol, Projeto III e como Orientador de

Trabalho de Graduação Interdisciplinar. 
OUTRAS EXPERIÊNCIAS RELEVANTES EXPERIÊNCIAS RELEVANTES COM FAVELAS

1999

Planejamento / Projeto

Estudo de viabilidade técnica e econômica para intervenção em 3 áreas, Santo André - SP

Função: Arquiteto e Urbanista [USINA CTAH].

1993 - 1997

Planejamento / Projeto

Vila Senhor dos Passos, Belo Horizonte - MG

Função: Arquiteto e Urbanista [USINA CTAH].

\section{4 - 1995}

Planejamento / Projeto Urbanização da Vila Popular, Diadema SP

Função: Arquiteto e Urbanista [USINA CTAH].

VER FICHA DE PROJETO em Cap.2

1993 - 1995

Planejamento / Projeto

Urbanização Favela Macaúba, Diadema - SP

Função: Arquiteto, Urbanista, e acompanhamento de obras [USINA CTAH].

1994

Planejamento / Projeto

Urbanização Favela Carapeba, Diadema - SP

Função: Arquiteto e Urbanista [USINA CTAH].

I Foro do Habitat Popular em Angola, Luanda, Angola Agente Organizador: CDG - Carl Duisberg Geselschaft e pela Universidade Nacional de Angola - UNAN. Função: organização e participação.

Planejamento / Projeto

Estudo preliminar para implantação de um Parque Metropolitano em Nova Iguaçu - RJ

Função: Arquiteto e Urbanista [USINA CTAH]. 

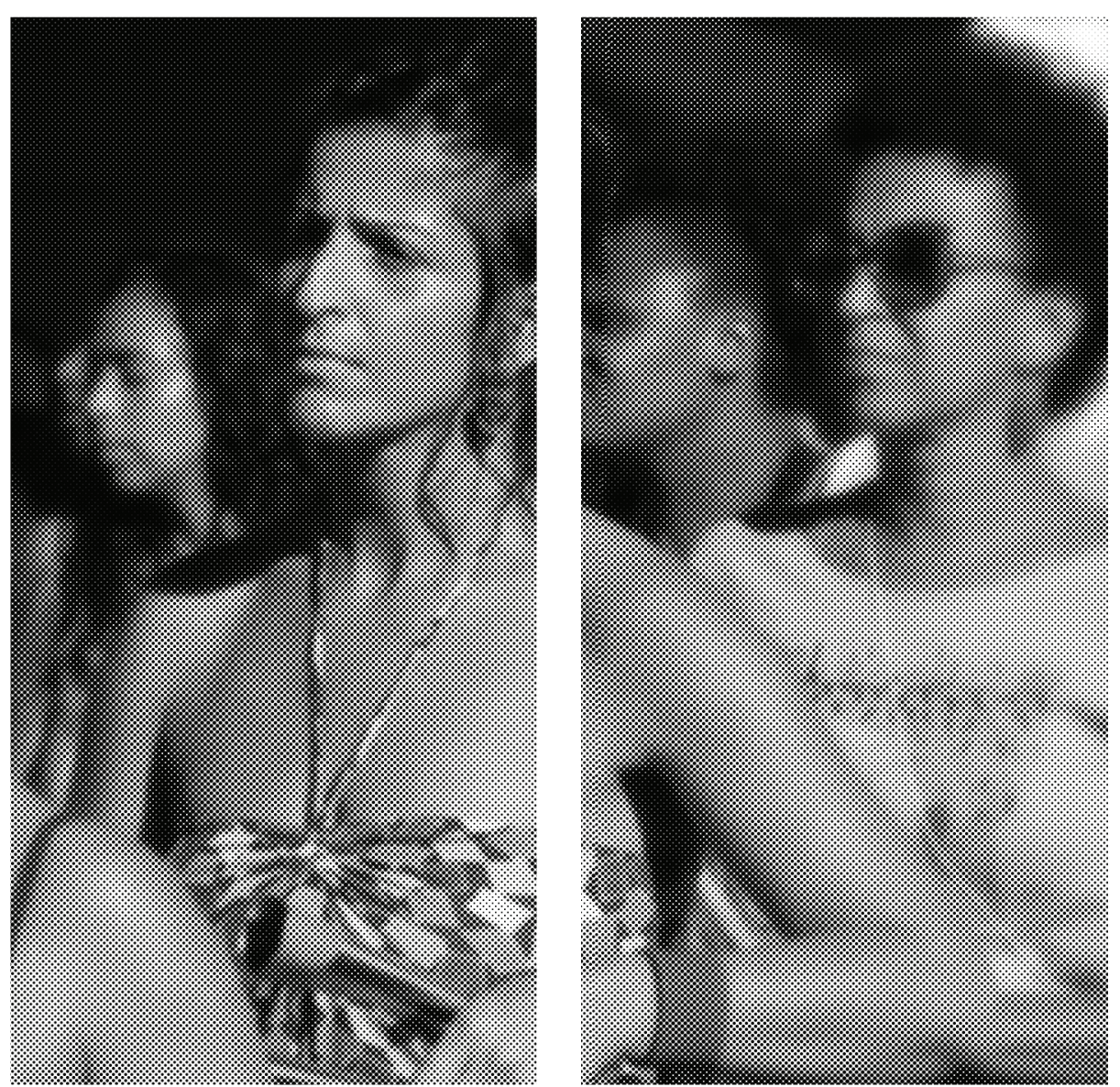

\section{HELOISA DINIZ DE REZENDE} (1976)

\section{Formação}

2012 - 2015

Mestrado em Arquitetura e Urbanismo. FAUUSP, Brasil

Título: Forma. Reforma. Desforma. O novo

formato da política pública para favelas.

Orientador: Yvonne Miriam Martha Mautner.

$1996-2002$

\section{Graduação Faculdade de Arquitetura e} Urbanismo da Universidade de São Paulo, FAUUSP, Brasil

\section{Formação Complementar}

2015

Temas Controvertidos de Direito Urbanístico. Escola Paulista da Magistratura, EPM, Brasil.

\section{9}

Economia Solidária e Tecnologia Social Latina. Universidade Estadual de Campinas, UNICAMP, Brasil.

\section{5}

Formação do Pensamento Crítico Brasileiro. Casa das Cidades/ Laboratório de Assentamentos Humanos da FAU-USP, C.CIDADES/ LABHAB, Brasil. 


\section{OUTRAS EXPERIÊNCIAS RELEVANTES EXPERIÊNCIAS RELEVANTES COM FAVELAS}

\section{6}

Gestão

SEHAB - Secretaria de Habitação, Prefeitura Municipal de São Paulo, PMSP, Brasil.

Agente Organizador: SEHAB - SP. Agente Contratante: SEHAB - SP, PAC UAP (Programa de Aceleração do Crescimento / Urbanização de Assentamentos Precários).

Breve descrição: Gestão de Contratos e Convênios do PAC UAP em diversas favelas do munícipio.

\section{3 - 2016}

Gestão

Secretaria de Habitação e Desenvolvimento Urbano da Prefeitura de Osasco, Brasil

Agente Organizador: Secretaria de Habitação e Desenvolvimento Urbano da Prefeitura de Osasco.

Agente Contratante: Secretaria de Habitação e Desenvolvimento Urbano da Prefeitura de Osasco Cohab-SP, PAC, Programa de Subsídio à Habitação de Interesse Social (PSH), Papel Passado e entre outros programas federais. Função: Arquiteta e Urbanista, Coordenadora na área de Regularização Fundiária de Assentamentos Precários do município de Osasco.

Breve descrição: Desenvolvimento de processos e de projetos de Regularização Fundiária, Urbanização de Assentamentos Precários. Desenvolvimento de Projetos e Planos de Regularização Fundiária de áreas em regularização.

2012 - 2013

Gestão / Planejamento / Projeto GSP - Gerenciadora, CDHU (Cia de Desenvolvimento Habitacional e Urbano) do Estado de São Paulo, Brasil

Função: Gestora de Projetos dos municípios da Serra do Mar e do Vale do Ribeira do Estado de São Paulo.

Breve descrição: Desenvolvimento de projetos habitacionais - HIS, edifícios de uso misto e de serviço; Elaboração de estudos preliminares, diretrizes e viabilidade dos empreendimentos; Gestão de contratos de empresas para elaboração de projetos; Gestão de contratos entre CDHU e municípios. 
EXPERIÊNCIAS RELEVANTES COM FAVELAS

2011 - 2012

Planejamento / Projeto

Regularização Fundiária e Proposta

Urbanística de Assentamento Informal

Jardim Jaqueline, São Paulo

Agente Organizador: Defensoria Pública do Estado de São Paulo - Extrema

Construções / Integra Desenvolvimento Urbano Ltda.

Agente Contratante: Defensoria Pública do Estado de São Paulo.

Função: Coordenadora da Equipe Urbanística.

Breve descrição: Projeto derivado de indicação de processo por Defensoria Pública do Estado de São Paulo. Realização de levantamentos físicos, e trabalho social com lideranças da comunidade para cenários de intervenção urbana.

Observações: Nem a regularização, nem projeto de urbanização chegou a ser concretizado na sua totalidade ou houve intervenção.

2006 - 2011

Gestão / Planejamento / Projeto

Secretaria de Desenvolvimento Urbano, Habitação e Meio Ambiente, Prefeitura de Taboão da Serra - SP

Agente Organizador: Secretaria de Desenvolvimento Urbano, Habitação e Meio Ambiente.

Agente Contratante: Secretaria de Desenvolvimento Urbano, Habitação e Meio Ambiente.

Função: Gestora, Coordenadora de Equipe.

Breve descrição Elaboração e coordenação de levantamentos, diagnósticos, projetos de urbanização e reassentamento, e acompanhamento de obra de assentamentos no município.

2007 - 2010

Gestão / Planejamento

Jardim Santo Onofre, Taboão da Serra, SP

VER FICHA DE PROJETO em Cap.2

$2006-2010$

Gestão / Planejamento / Projeto Jardim Silvio Sampaio, Parque São Joaquim e Jardim Leme, Taboão da Serra - SP

Função: Gestora, Coordenadora de Equipe.

VER FICHA DE PROJETO em Cap.2 


\section{OUTRAS EXPERIÊNCIAS RELEVANTES}

$2002-2009$

Planejamento / Projeto Usina CTAH, Brasil

Função: Associada e Coordenadora. Breve descrição: Participação nos processos e projetos de mutirão de HIS, desenvolvimento de projeto de praça e Centro Comunitário.

$2000-2002$

Planejamento / Projeto

Integra - Cooperativa de Trabalho Interdisciplinar, Brasil

Função: Estágio em Arquitetura e Urbanismo.

Breve descrição: Acompanhamento Social e Obra de HIS, e Elaboração do

Projeto Piloto Escola Itinerante em Guarulhos com a Incubadora de Pesquisas Tecnológicas (ITCP) da Universidade de São Paulo (USP).

1999 - 2000

Acadêmica

Laboratório de Habitação e Assentamentos Humanos, LABHAB-USP,

Brasil.

Função: pesquisadora Breve descrição: participação na elaboração da publicação "As políticas habitacionais da Prefeitura Municipal de Santo André - 1997 - 2000. Ações em um cenário de exclusão", realizada sob a orientação da Prof. Ermínia Maricato e Minoru Naruto. 

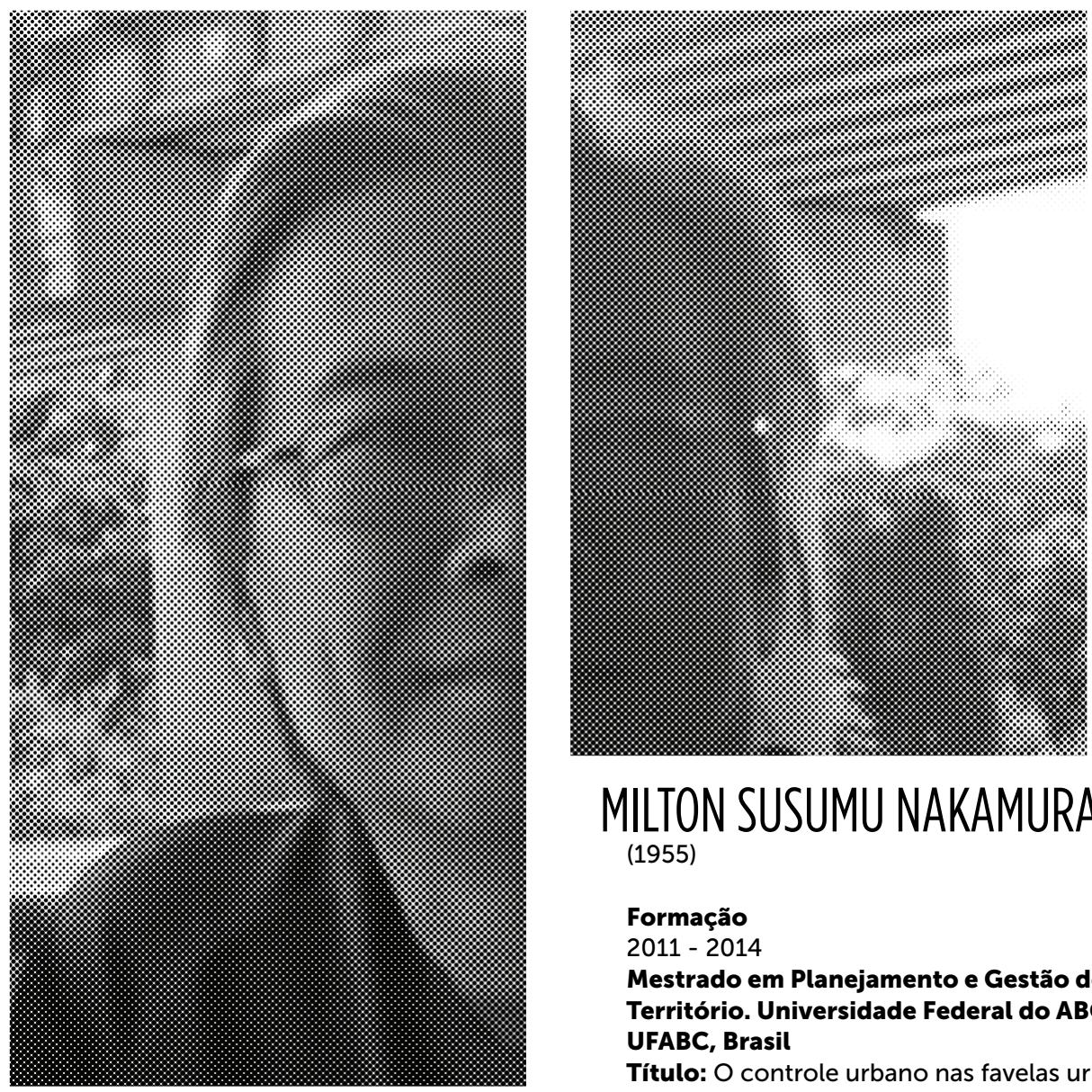

\section{MILTON SUSUMU NAKAMURA} (1955)

\section{Formação}

2011 - 2014

Mestrado em Planejamento e Gestão do Território. Universidade Federal do ABC, UFABC, Brasil

Título: $O$ controle urbano nas favelas urbanizadas, o caso da região do $A B C$

Orientador: Rosana Denaldi

$1977-1983$

Graduação Faculdade de Arquitetura e Urbanismo da Universidade de São Paulo - FAUUSP, Brasil

Formação Complementar relevante para experiência com favelas

2010

Ações Integradas de Urbanização em Assentamentos Precários. Prefeitura do Município de São Bernardo do Campo, DAE, Brasil. 


\section{OUTRAS EXPERIÊNCIAS RELEVANTES EXPERIÊNCIAS RELEVANTES COM FAVELAS}

\author{
2015 - atual \\ Acadêmica \\ Centro Universitário das Faculdades \\ Metropolitanas Unidas, FMU, Brasil \\ Função: Docente de Graduação das \\ disciplinas: Urbanismo e Paisagismo em \\ Áreas Periféricas e Projeto de Edificação: \\ Sistemas Construtivos.
}

2007 - atual

Gestão / Planejamento / Projeto

Barossi Nakamura Dedecca Arquitetos

Ltda., BND, Brasil.

Função: Sócio Diretor (afastado de 2009 a dezembro de 2016).

Breve descrição: participação e desenvolvimento em projetos de espaços e edifícios públicos e privados de variadas naturezas: habitação individual, coletiva, saúde, educação, cultura, turismo, entre outros. Participação consultoria para elaboração de Planos Diretores dos municípios de Diadema (2007) e Jandira

(2006-atual).
2016

Gestão / Planejamento

Secretaria de Habitação do Município

de São Paulo, SEHAB-SP, Brasil

Agente Organizador: SEHAB-SP.

Função: coordenador de Projetos e

Obras; responsável pelo Programa de Urbanização de Favelas.

Breve descrição: gestão de projetos dos Perímetros de Ação Integrada, PAI contratados pela SEHAB por meio do Concursos de projetos RENOVA e gestão de contratos de obras de urbanização de favelas e produção habitacional em todas as regiões do município, incluindo o Programa Mananciais e participação na elaboração do projeto de lei do Plano Municipal de Habitação.

VER FICHA DE PROJETO em Cap.2

\section{3 - 2015}

Gestão / Planejamento

Prefeitura do Município de Mauá - PMM, Brasil

Agente Organizador: Prefeitura de Mauá - Secretaria de Obras e Habitação.

Agente Contratante: Prefeitura de Mauá - Secretaria de Obras e Habitação, PAC UAP.

Função: secretário adjunto da Secretaria de Obras.

Breve descrição: responsável pela coordenação do projeto de urbanização de favelas do complexo Chafik-Macuco, Cerqueira Leite e Jardim Oratório, projetos de contenção de encostas em áreas de risco geológico-geotécnico.

\section{1 - 2012}

Gestão / Planejamento

Prefeitura do Município de Diadema PMD, Brasil

Função: Assessor do Secretário de Obras; Assistente do Secretário de Serviços e Obras; Secretário de Habitação e Des. Urbano (2011-2012).

Breve descrição: i. assessorar o secretário na gestão de projetos urbanos e programa municipal de redução de riscos, PMRR; ii. Gestão da secretaria municipal organizada em departamento de controle de uso e ocupação do solo, habitação, trabalho social e regularização fundiária, exercício da presidência do Conselho Gestor do Fundo Municipal de Habitação Popular de Interesse Social, FUMHAPIS. 
EXPERIÊNCIAS RELEVANTES COM FAVELAS

2009 - 2011

Gestão / Planejamento

Secretaria da Habitação do Município

de São Bernardo do Campo - SEHAB

-PMSBC, Brasil

Agente Organizador: SEHAB-PMSBC.

Agente Contratante: SEHAB-PMSBC /

PAC-UAP e PMCMV.

Função: consultor de regularização fundiária, Gestor de projetos de urbanização e regularização fundiária de assentamentos precários e planejamento habitacional. Breve descrição: coordenador de projetos de Urbanização e Regularização Fundiária de Assentamentos Precários e gestão de projetos do Programa Minha Casa Minha Vida.

2008

Planejamento / Projeto

Urbanização de Assentamento Precário Núcleo Santo Onofre, Taboão da Serra, SP

Agente Organizador: Sec. Des. Urbano, Hab. e Meio Ambiente de Taboão da Serra. Agente Contratante: Sec. Des. Urbano Hab. e Meio Ambiente de Taboão da Serra, Projeto selecionado para o PAC-1.

Função: arquiteto, urbanista, coordenador [BND Arquitetos]

Breve descrição: o núcleo Santo Onofre ocupa uma área pública pertencente ao sistema de recreio do loteamento de mesmo nome, formado por uma encosta ingreme, com aproximadamente 200 famílias.

Observações: projeto não executado.

\section{5}

Planejamento / Projeto

Urbanização da favela Jardim Mangue

Seco, Guarujá, SP

Função: arquiteto, urbanista, consultor. Breve descrição: projeto executivo de urbanização e implantação de unidades habitacionais sobrepostas e módulos evolutivos; em parceria com Geométrica Engenharia.

\section{5}

Planejamento / Projeto

Urbanização da favela Vila Lígia, Guarujá, SP

Função: arquiteto, urbanista, consultor. Breve descrição: projeto de urbanização e recuperação de área degradada de mangue; em parceria com Geométrica Engenharia. 


\section{OUTRAS EXPERIÊNCIAS RELEVANTES EXPERIÊNCIAS RELEVANTES COM FAVELAS}

\section{3}

Planejamento / Projeto

Urbanização da Favela Santo Eduardo, São Paulo

Agente Organizador: Prefeitura Municipal de São Paulo.

Agente Contratante: Prefeitura Municipal de São Paulo.

Função: arquiteto, urbanista, consultor. Breve descrição: Projeto executivo de urbanização e implantação de unidades habitacionais sobreposta; Em parceria com Geométrica Engenharia.

\section{9 - 1996}

Gestão / Planejamento Prefeitura do Município de Diadema, PMD, Brasil

Função: chefe de Serviço de Projetos (1989-1991); chefe da Divisão de Projeto (1991-1992); chefe de Divisão de Planejamento Habitacional (1993-1994); Assistente da Diretoria de Planejamento (1994-1995); Diretor do Departamento de Habitação (1995-1996); Assistente do Chefe de Gabinete do Prefeito (1996). Breve descrição: gestão de projetos, participação na elaboração do Plano Diretor de 1993, coordenação de obras de urbanização de favelas, estabilização de encostas, implantação do programa de urbanização por auto-gestão, aquisição de terras para programas habitacionais, assessoria à movimentos de moradia, promoção do Fórum Municipal de Habitação, participação no conselho gestor do Fundo Municipal de Habitação Popular de Interesse Social, FUMHAPIS.

VER FICHA DE PROJETO em Cap.2

1983 - 1988

Gestão / Planejamento / Projeto Galpão Arquitetos, GALPÃO, Brasil.

Função: Sócio Diretor.

Breve descrição: participação e desenvolvimento em projetos de espaços e edifícios públicos e privados de variadas naturezas: habitação individual, coletiva, saúde, educação, cultura, turismo, entre outros. 
PORTAL DE
BUSCA INTEGR BUSCA INTEGRADA

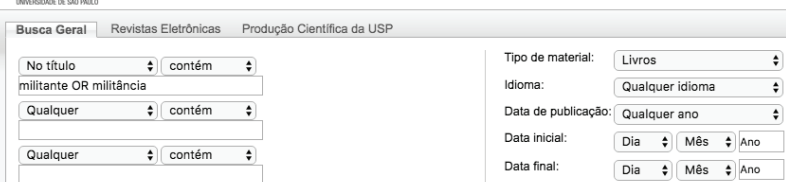

\section{Buscar Busca simples}

๑r Iss

Expandir meus resultados

Expandir meus resultados

Mostrar somente

Recursos online (16)
Disponivel na Biblioteca $(84)$

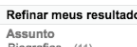

Assunto
Biografias (11)
Movimentos Sochis

Movimentos Sociais (6)

ernandes, Florestan 1920-1995 (5)

Mais opcōes $v$

Autor/Criador
Plekhanou, $G\left({ }^{(4)}\right)$
Nascimento, $M(4)$
Borf, $L$ (3)

Boff, $L$ (3)
Dias, $E$ (3)
Garcia, $S$ (3)

Mais opçöes $v$

Data de publicaçăă
AAtes de 1974 (17)
1974 até $1986 \quad(20)$
11087

1974 até 1986
1997 atót 1908 até 2009

Após 2009 (21)

Mais oppōes $v$

Base de dados/Biblioteca
FFLCH - Fac FF Let $\mathrm{C} C$ Ciências

FEA-Fac Econ Adm e Contabilidade

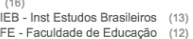

FE- Facaldade de Educagăa

Mais opp̧öes $~$

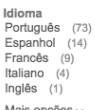

Mais op̧̧̄es $\vee$

Novas pesquisas sugeridas

deste autor:
Plekhanov, $G$
Nascimento,

Boff,,
Dias, $E$
Garcia, $S$

Neste assunto:
Bisografias
Moniters

Fernandes, Florestan 1920-1995

Apoio: TFAPESP
Convidado(a) 合 Neu Espaço Minha conta Identificaçăo

\begin{tabular}{ll|l|l} 
Bases (A-Z) Bibliotecas USP & Ajuda & IdiomaPortuguêsy
\end{tabular}

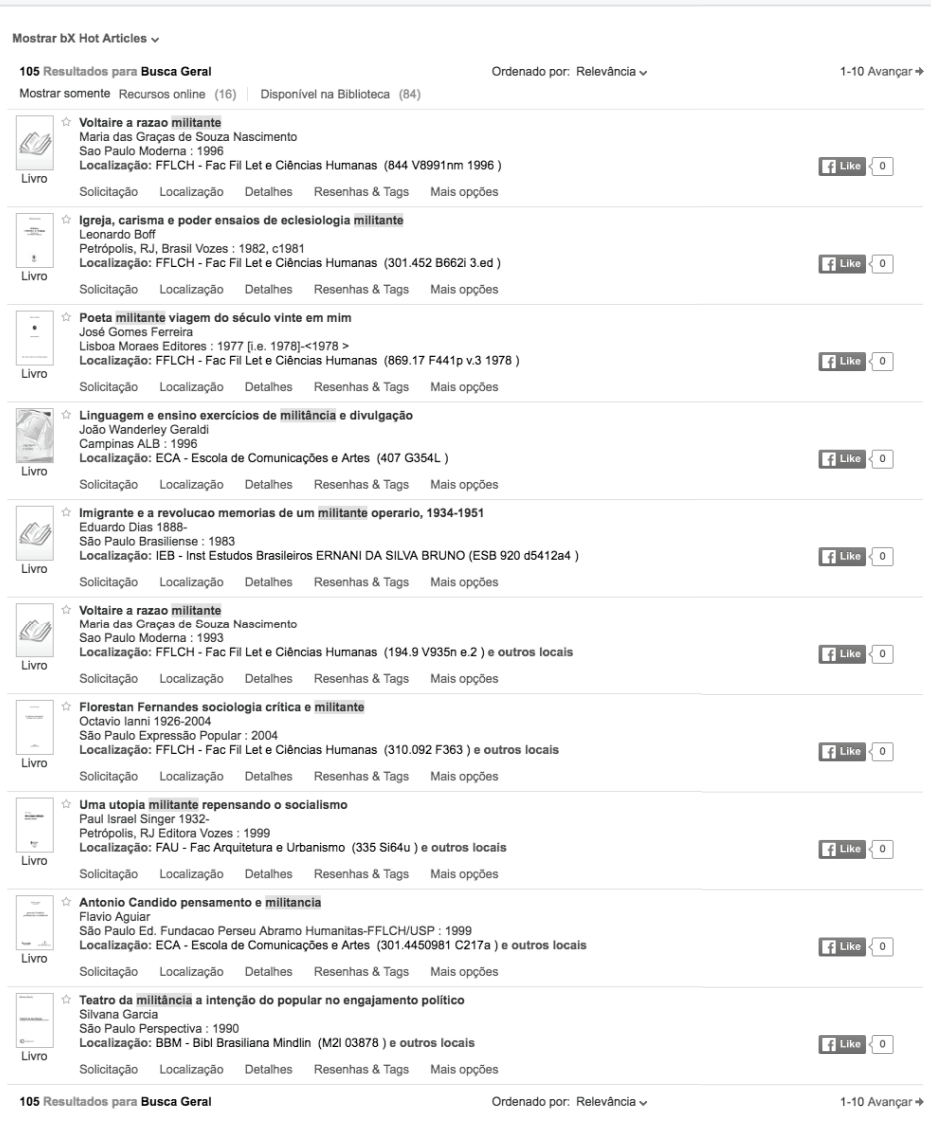

de pesquisa SIBiUSP Portal

de Busca integrada, pelos

termos MILITANTE or MIL-

ITÂNCIA

Fonte: www.buscaintegrada

usp br

Acesso em 16/02/17
Como podemos observar em seus currículos, o grande número de experiências com favelas (e com a habitação de interesse social), fazem-nos antever a particularidade dos percursos profissionais destes sujeitos. No entanto, não é pela quantidade que podemos distinguir ou conceituar estas atuações como militantes.

Para tal precisamos discorrer e apresentar algumas considerações que nos permitam conceituar esta prática, em seu contexto, alcances e limites.
A pesquisa bibliográfica sobre a militância revelou que a mesma não aparece descrita na literatura acadêmica como um conceito bem delimitado. Encontramos poucas referências que a explorassem, com o rigor que acreditávamos ser necessário à delimitação da prática do engajamento profissional e social em um campo de atuação que entendemos como político.

$\mathrm{Na}$ ciência política, encontramos algum esclarecimento para a delimitação do campo de atuação profissional onde a dimen- 
são de códigos éticos é considerada como componente essencial. Para Ham e Hill ( 1993 ), a análise entre a ética e a atuação profissional fica em torno de, por um lado, a definição de códigos éticos que se valem mais para proteção entre os colegas da mesma profissão, e por outro lado, como uma forma de poder e de legitimidade perante a sociedade, o que, por exemplo, podemos claramente associar à profissão de médico (HAM e HILL, I 993, p. I 94-ı 96).

Não é esta relação ética do exercício da profissão que nos interessa, mas aquela que parte da vontade individual para uma mobilização que, em seu fim (e seu princípio), é social e politicamente engajada e se importa com o outro, o que se demonstra na prática.

A pesquisa bibliográfica sobre o termo: Militante nos revelou que o termo é muito recorrente no vocabulário das lutas, dos movimentos sociais e de partidos políticos, no sentido de defesa de causas que ensejam plataformas reivindicatórias em geral.

A própria literatura marxista, inspiradora das abordagens adotadas nesta pesquisa, na sua origem, não parece fazer uso da palavra militante nos documentos que ensejam teses de teor mais crítico e analítico. O termo militante aparece nos documentos em que se conclama a militância à luta, com teor de manifesto e disseminação de informações partidárias de uma causa.

Por exemplo, não encontramos o termo militante nos volumes de O CAPITAL ( 1867 ) a tese mais disseminada de Karl Marx, em que o pensamento do autor congrega muitas de suas teses em obras anteriores e, ao mesmo tempo, traz importante contribuição sobre a concepção materialista - dialética da história e da luta de classes. Já em O Manifesto Comunista (I 848), texto em que Marx e Engels se utilizam de tom conclamatório, convidando trabalhadores a se engajarem na luta política, o termo militante vai figurar apenas nos prefácios escritos exclusivamente por Engels a partir

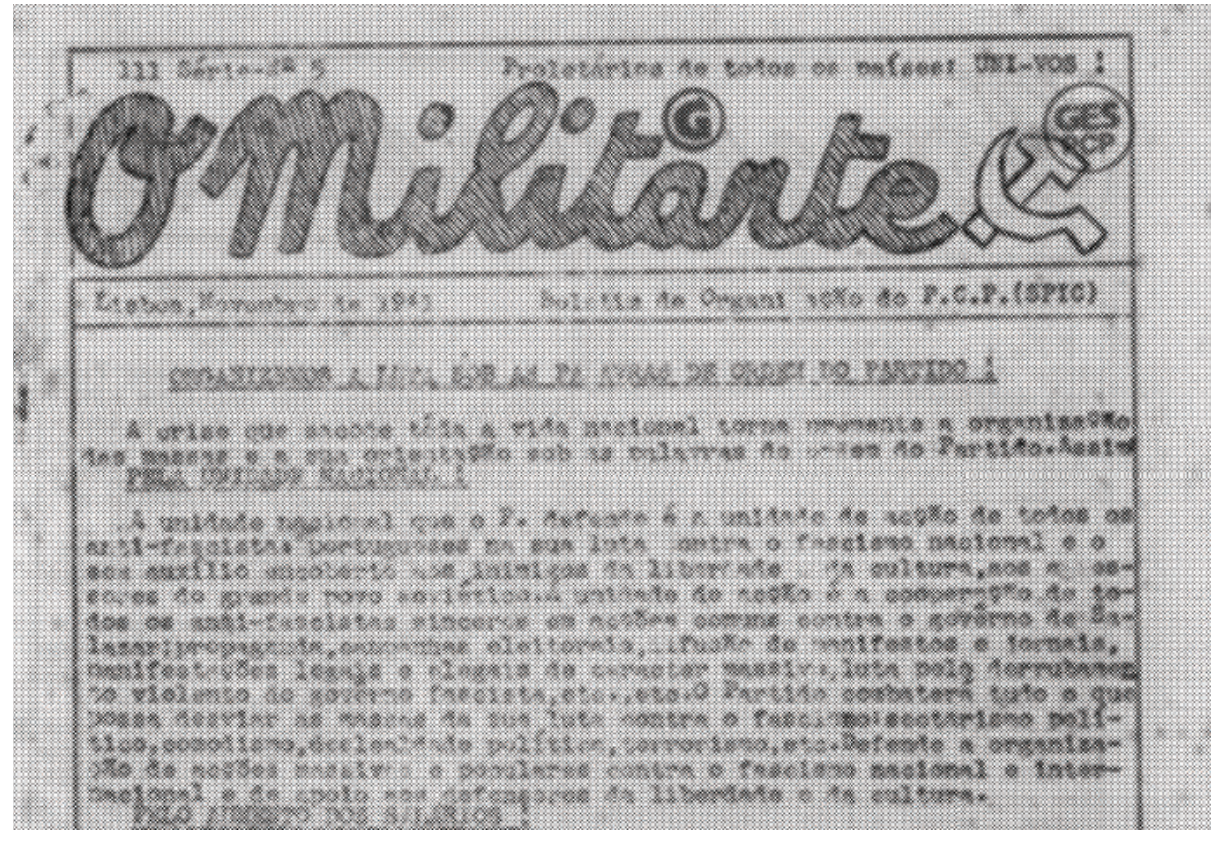

de i 888 , como por exemplo, quando este se refere ao proletariado militante do comunismo. Na obra de Lenin, O signifiCADO DO MATERIALISMO MILITANTE ( 1922 ) aparece na obra em que discute o papel da revista intitulada Sob A BANDEIRA Do marxismo (criada pelo Outubro Vermelho para o XI Congresso do Partido Comunista Bolchevique), quando se refere ao papel militante dos órgãos de imprensa a serviço da disseminação do materialismo histórico e da luta comunista, ou daquilo que poderia se designar como a disseminação ou a "propaganda" militante do materialismo histórico-dialético e do ateísmo em Marx e Engels. ${ }^{4}$

Olhando para o campo que aqui nos interessa, alguns ensaios aproximam uma relação entre militância e favelas, no entanto, também eles direcionam para análises sobre lutas sociais por movimentos organizados ou políticas públicas, e seus interlocutores. Estes recaem sobretudo em atuações colocadas através de atores em contextos político-partidários, e apesar de reconhecermos a importância destes para a definição do campo de atuação em favelas, o nosso direcionamento de pesquisa está fig 2. Militante Clandestino.

Jornal do Partido Comunista Português durante o periodo da Ditadura (1933-1974)

Fonte: www.pcp.pt/o-militante-clandestino Acesso em 16/02/17 4. Cf. versões eletrônicas de O Capital, O manifesto Comunista e O significado do materialismo militante para facilitar busca pelo termo. Disponiveis respectivamente em : bibliotecacomuna.blogspot.com.br/2012/03/ocapital-karl-marx-completo-2-edicoes.html; www.pstu.org.br/sites/ default/files/biblioteca/ marx_engels_manifesto. pdf; www.scientific-socialism.de/LeninMaterialismoMilitanteCapI. htm

5. Para além dos trabalhos individuais, encontramos produções 
conjuntas de LOPES

e PULHEZ (2008a,

2008b) que contribuem

para a bibliografia sobre

o tema da militância e

da prática profission-

al de arquitetos em

favelas.

6.Pulhez (2007) consegue

apresentar uma

detalhada recuperação

histórica sobre o campo

social da arquitetura no

Brasil. Não nos propo-

mos repetir tal desafio,

mas partir dele para

iluminarmos as suas

relações com as práticas

utilizadas pelos ar-

quitetos militantes, não

apenas em assessorias

técnicas, mas também

em outras formas de

prática profissional. E

como nas suas práticas

e tensionamentos a par-

tir da estética, técnica

e ética encontramos a

definição de militância.

Acreditamos ser esse

o contributo para o

campo do exercício de

projeto e da produção

de interesse social da ar-

quitetura e urbanismo. voltado para a atuação do arquiteto na prática de projeto.

As descrições sobre processos de projeto com aproximações à instrumentalização numa lógica de luta reivindicatória e progressista aparecem sobretudo em depoimentos e relatados de sujeitos associados ao questionamento e posicionamento do arquiteto como ator político. Nem sempre estes testemunhos são relacionados especificamente com favelas, mas todos eles tensionam o "lugar" e "papel" do arquiteto aproximando-o dos mais pobres e dos que moram em condições consideradas mais precárias.

Autores como Turner ( I 972, I 976) e Fathy ( ( 980), no plano internacional, vãose destacar pela descrição de uma prática profissional próxima dos pobres, valorizando estes como protagonistas das suas próprias construções. Em território nacional, Santos ( 198 I), Bonduki ( I 992), Maricato ( I 996), Peterson (2009), Rezende (20 I 5), apenas para nomear alguns que, na recuperação de suas trajetórias pessoais, vão margeando o conceito de militância em denominações que tendem a reconhecer na sua ação. Esta, recorrentemente se caracteriza por uma aproximação a esses contextos numa atitude que busca a horizontalidade, o trabalho participativo e a transformação social, ao qual está relacionado o embasamento ou mobilização de fundo político ou ideológico e certo espírito de sacrifício.
Então eu fui buscar uma ligação com uma coisa mais concreta: os oprimidos, os que estavam do outro lado, embora estivessem sempre presentes nas justificativas dos nossos projetos. Recebi um convite de um padre na área de São José, em Interlagos. Eles estavam iniciando um movimento de transportes e precisavam uma orientação profissional. (...)

Foi uma coisa muito sacrificada durante esses anos todos. Eu me sinto um pouco como aquelas... como é que se chamam essas igrejas de gente muito fanática?... eu precisava ir. Era uma necessidade que eu tinha que conhecer, de acompanhar aquele tipo de processo. Pelo menos era uma ligação com uma outra realidade. Então, eu fiz na base da ideologia, só. (depoimento de Erminia Maricato em GARCIA, 1983, p.80-81)

É em Lopes (20 I I) e Pulhez (2007) $)^{5}$ que encontramos uma delimitação mais aproximada ao campo conceitual da militância que nos interessa abordar. Pulhez (2007) elabora um vasto mapeamento, construindo a trajetória de aproximação do arquiteto à favela no Brasil ${ }^{6}$. O seu foco vai tender para o reconhecimento por parte destes profissionais (uma parte deles pelo 
menos) do valor cultural e construtivo das morfologias habitacionais criadas na carência de recursos. Este quadro vai embasar a atuação dos casos de estudo que a autora apresenta focando nas experiências de três assessorias técnicas em urbanização de favelas na Região Metropolitana de São Paulo. A apresentação tanto do seu mapeamento histórico, quanto destes casos, aborda o "lugar comum" do arquiteto e urbanista, através da introdução e da importância dada aos componentes sociais, ao projeto participativo que busca a emancipação, e à relação direta destes com o desenho e as técnicas usuais da arquitetura e urbanismo.

Mesma linha é apresentada por Lopes (20 I I ) onde as contradições da atuação do profissional são exploradas a partir da sua trajetória pessoal. As experiências no LabHab da Faculdade de Belas Artes ${ }^{7}$ e dentro da assessoria técnica a Usina $\mathrm{CTAH}^{8}$ possibilitam a análise crítica embasada no conhecimento empírico. Para Lopes a centralidade da crítica encontra-se no sistema de produção que, dentro da Usina, toma a defesa pela produção autogestionária, através de um trabalho dos arquitetos e urbanistas, convencionalmente definido como 'trabalho social'. Nas práticas da Usina constam a busca, encontro e resposta a movimentos de luta por moradia, direito à cidade, ou qualquer outra população com os seus direitos relacionados com a produção do espaço ameaçados, e com necessidade de assessoria técnica para fortalecimento dessa luta. Nesse encontro surgem confrontos, mas também uma grande reflexão, sobre a possibilidade de atuações potencialmente paternalistas ou impositivas e de práticas assistencialistas ou voluntaristas, por parte dos assessorados.

- que existia era uma impressão comum lentre os membros da Usina] de que o trabalho social que se pretende não é um trabalho assistencialista. [...] Isso é consenso, todos concordam que não é pra ser um trabalho assistencialista. Mas aí, o que colocar no lugar disso? Se ele não é assistencialista, o que ele é então? Acho que para essa questão, normalmente o que a gente sempre tendeu a responder é que ele é um trabalho essencialmente político e por isso é um trabalho social. [...] Mas o que é esse trabalho político? Eu acho que a gente sempre viveu essa crise, de ficar entre um trabalho militante, de militância efetiva, de interferência, de composição do nosso esforço como técnicos junto ao esforço dos movimentos - numa perspectiva essencialmente política - e dos próprios grupos com os quais a gente trabalhou, e por outro

\author{
7. O LabHab-Laboratório \\ de Habitação do Curso de \\ Arquitetura e Urbanismo \\ da Faculdade de Belas de \\ São Paulo, fundado em \\ I982, tratou-se de uma \\ experiência pioneira no \\ campo da habitação de \\ interesse social em São \\ Paulo. Reunia professores \\ e estudantes do curso $e$ \\ propunha a comple- \\ mentar a formação dos \\ estudantes através de \\ atividades de assessoria \\ às comunidades com \\ dificuldade de acesso aos \\ serviços destes profission- \\ ais (arquitetos e engen- \\ heiros). Desta experiência \\ é reconhecido o projeto \\ de Urbanização Recanto \\ da Alegria. Para além da \\ formação de alunos (e \\ professores) a experiência \\ torna-se referência de out \\ ros projetos acadêmicose \\ até politicas de habitação \\ social-alguns dos seus \\ participantes vão integrar \\ a gestão municipal de \\ Luiza Erundina, prefeita \\ de São Paulo (1989- \\ 1992). João Marcos \\ Lopes não participa
}




\footnotetext{
"oficialmente" mas do

LabHab mas do convivio

diário e aproximado

com os seus integrantes,

acaba por participar

ativamente dos processos

desenvolvidos. (LOPES,

201 I $p .63-64$ )

8. João Marcos A. Lopes é

um dos membros-fun-

dadores da Usina e

mantêm uma atuação

ativa na assessoria

desde a sua fundação.

9. PINHEIRO, Jair. O

sujeito da ação política:

notas para uma teoria.

Lutas Sociais (PUCSP),

São Paulo, v. 3, p. I43-

I63, 1997
}

lado, um trabalho político, mas

num sentido menos militante, num sentido de tentar compreender que necessariamente 0 nosso trabalho técnico não deixa de ser político também. (entrevista a João Marcos Lopes em PULHEZ, 2007, p.130-131)

Se ambos os referidos autores tangiam definições, reflexões e questionamentos sobre a militância aproximados ao que aqui nos propomos abordar, não chegam a circunscrever o conceito à prática, ao exercício que, se por um lado é político, por outro, não tem essa pretensão. A militância em arquitetura e urbanismo em urbanização de favelas, como aqui é colocada e encontrada nos sujeitos estudo de caso, trata-se do exercício de técnicas, estéticas e éticas, ou pelo menos na sua tentativa através das práticas utilizadas.

Entendemos que, para a tentativa desta conceituação, precisamos beber na filosofia procurando a justificação para a atuação de sujeitos e como, num tensionamento entre estética, técnica e ética, encontramos a ação política onde assumem a nossa conceituação de militantes.

Esta exploração, reconhece na pesquisa a partir dos depoimentos pessoais, a importância do indivíduo e das tomadas de decisão dotadas de intenção o que, em Pinheiro ( ( 997) ${ }^{9}$, distingue indivíduo de sujeito.

\begin{abstract}
Essas considerações exigem estabelecer uma distinção fundamental entre indivíduo, como unidade estatística discreta, e sujeito. (...) O mesmo já não é possivel com relação ao termo sujeito, pois este só existe no interior de uma situação como agente dela. (...)

Indo além, o sujeito é instaurado na e pela situação. (PINHEIRO, 1997, p.145)
\end{abstract}

As definições de Pinheiro sobre as dimensões da constituição do sujeito da ação política, nos parecem muito pertinentes para tratar dos militantes em urbanização de favelas aqui abordados numa leitura a partir de seus ações, reflexões e depoimentos. $\mathrm{O}$ autor aborda as nuances do individualismo e subjetividade da atuação que se refletem nas ações ou práticas e permeiam as dimensões ontológica, outra de atualização histórico-social e sobretudo, uma dimensão empírica das ações efetivas, que ao fim e ao cabo "concentra em si todas as formas de constituição do sujeito e representa a forma mais imediata e visível de manifestação objetiva da subjetividade" (PINHEIRO, I 997, p. I 44)

O autor atenta também para a importância da contextualização de tal sujeito, da sua cultura e formação, e demais vínculos e condicionantes externas que vão influenciar as suas ações, dotadas de intenção, e nessa forma, distinguindo-o do indivíduo. 
Compreendemos portanto que o sujeito se assume quando age com intenção perante e instigado por determinada situação. Isso nos parece bastante aderente à forma como exploramos a trajetória dos militantes aqui pesquisados. Reconhecemos na sua ação intencional a presença do campo das ideias, tanto na intenção quanto na reflexão sobre o que o rodeia, mesmo que inconscientemente, ou melhor, numa reflexão pouco aprofundada. Assim, reconhecemos que no uso das ideias, o sujeito se empenha numa ação política na medida em que as ideias também integram as lutas políticas como arma de luta. Esta noção é muito importante para o exame empírico da categoria sujeito da ação política. (PINHEIRO, I 997, p. I 48)

$\mathrm{Na}$ pesquisa aqui colocada, encontramos arquitetos agindo na favela, instigados pela mesma e pela realidade que os rodeia. Resta-nos considerar o quanto desta atuação e das suas ideias, refletem a intenção de luta política que propomos demonstrar.

Os sujeitos pesquisados reconhecem as desigualdades sócio-espaciais na população moradora em favelas, ainda que não necessariamente tratem-nas nos marcos da crítica capitalista e nas formas de luta política acima colocadas. Tratam-se de sujeitos que se sensibilizam pela situação da favela e atuam no sentido de transformá-la, mesmo compreendendo as limitações e contingências para tal. Mas esta sensibilização e, principalmente, atuação está longe de ser uniforme. O que encontramos nestes sujeitos são indivíduos transformados na e com a favela, nas suas experiências acumuladas, e reflexões sobre a situação colocada e pelos outros que nela vivem. Situações que os emocionam, inspiram ou incomodam ao ponto de quererem agir sobre, mas ao mesmo tempo numa atitude de aproximação, onde acabam procurando agir com a população moradora, que também reconhece neles, em muitos casos outra forma de agir, mais dialógica, mais sensível, e que procura não se confundir com uma postura assistencialista.

Como casos de estudo, identificamos aqueles que nas suas atuações evitam fazê -lo, mas são conscientes que limiar é tênue e a linha pode ser facilmente cruzada. No entanto, insistimos em explorar este modo de fazer e agir na (e com) a favela. Exploramos este conceito a partir destes sujeitos que, na contradição, encontram a possibilidade de atuação, e procuram fazê-lo segundo os seus princípios.

Nesse sentido, as considerações que teceremos aqui sobre o arquiteto militante, partem de referências que não são diretamente relacionadas com este termo, tal como utilizado mais correntemente, mas que nos inspiraram a ensaiar algumas considerações que nos parecem relevantes para esclarecer o este que é o elemento central da pesquisa: a militância como um campo de ação política e sensível, em busca de uma ética, uma estética que se consolida através de experimentações técnicas no campo da urbanização de favelas.

\author{
Iо. PALLAMIN, Vera. \\ Aspectos da relação en- \\ tre o estético e o político \\ em Jacques Rancière. \\ Risco (São Carlos), v. \\ I2, p. 6-I6, 201 I. \\ I I. LIMA, Fellipe de \\ Andrade Abreu e. \\ Ética e estética nas \\ arte, arquitetura \\ e urbanismo \\ contemporâneos - \\ uma crítica realista. \\ Pós. Revista do \\ Programa de Pós-Grad- \\ uação em Arquite- \\ tura e Urbanismo da \\ FAUUSP, São Paulo, \\ n. 28, p. I58-I 8 I, dec. \\ 2010.
}


I 2. KATINSKY, Julio.

Técnica, Tecnologia e

Educação em Países

Subdesenvolvidos. e

TURNER, John F. C.

O Desafio do Apoio à

Autogestão. Tarefas

para o arquiteto. In:

MASCARÓ, Lucia

(coord.). Tecnologia E

Arquitetura. Nobel. São

Paulo, I 989.p.6 I-86 e

P.IO2-II

I3. LOPES, João Marcos

de Almeida. Em

memória das mãos: o

desencantamento da

técnica na arquitetura

e no urbanismo. Tese

de Doutorado em

Filosofia e Metodologia

das Ciências da Uni-

versidade Federal de

São Carlos. São Carlos :

UFSCar, 2006.
Na militância em urbanização de favelas, aqui explorada, parece haver a opção deliberada por uma atuação respeitosa com pré-existências sócio-espaciais, um olhar cuidadoso com histórias de vida e espaços autoconstruídos na carência de recursos, uma capacidade de projetar respeitando essas histórias, e reivindicando representações e técnicas projetuais que dialoguem com a materialidade e a subjetividade nas favelas.

Recorrer aos conceitos de técnica, ética e estética, para circunstanciar o nosso conceito de arquiteto: sujeito militante em favelas levou-nos, por sua vez, ao alargamento da pesquisa até ao campo das ciências política e social, e em espacial da filosofia e de conceitos trabalhados à luz dessa disciplina tais como: indivíduo, sensibilidade, cultura, política, trabalho e, por consequência, a conceitos marxistas de: sistema produtivo capitalista, luta de classes, exploração, dominação e alienação, conforme autores explorados a seguir.

Sobre a relação entre ética, estética e o político na arquitetura, recorremos aos texto de Pallamin $(20 \mathrm{r} 0)^{10} \mathrm{e} \mathrm{Lima}(20 \mathrm{I} 0)^{\mathrm{II}}$. Sobre técnica na arquitetura, procuramos o paralelismo com a tecnologia, na compilação de textos organizada por Lúcia Mascaró ( 1989 ), com especial interesse pelas contribuições de Julio Katinsky e John Turner ${ }^{12}$. E encontramos em Lopes (2006) ${ }^{13}$, uma exploração crítica sobre o uso da técnica (e da tecnologia) no papel do arquiteto, num questionamento filosófico sobre as usuais formas de trabalho do arquiteto com a introdução de possibilidades alternativas nos marcos da luta de classes e relações de dominação no capitalismo.

O militante aqui abordado escolhe a favela como campo de atuação, e reconhece-a como uma das morfologias urbanas resultantes do sistema capitalista, que gera desigualdades sócio-espaciais. Importa-nos principalmente compreender como, a partir dessa consciência, o sujeito atua e reflete sob essas mesmas contradições, procurando, através do sistema posto e dentro das limitações colocadas, efetuar alguma transformação nessa realidade.

Não pretendemos, a partir deste tema, sugerir que estes são os resultados mais harmoniosos ou esteticamente agradáveis, ou sequer, afirmar que os militantes se aproximam melhor dessa concepção ética e estética. Importa-nos apenas demonstrar como na atitude de reconhecimento da favela como seu campo de atuação e na sua atitude perante a realidade que lhe é colocada, a ação do arquiteto militante é dotada de significado político o que se amplia à sua concepção técnica, estética e ética, ou vice-versa.

Nos termos de Schiller ( I 99i), encontramos a relação entre o político e a estética, na noção de que as transformações materiais e sociais não são possíveis se não tiverem correspondência num campo sensível, e por que não dizer estético. No 
limite, esta aproximação, as atuações do sujeito possibilitam transformações dotadas de liberdade e sensibilidade, e ensejam uma relação direta com o contexto em que aquele se enquadra,

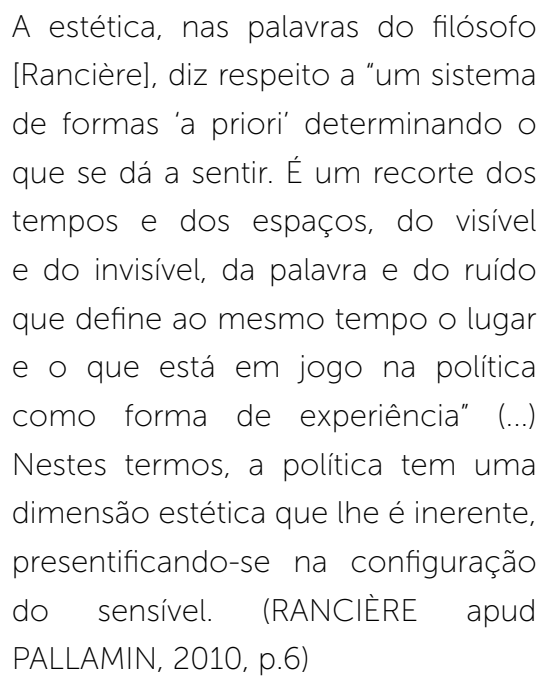

Esta atuação, não é por si só política, mas passa a sê-lo na medida em que embate com o sistema desigual e injusto, procurando a sua transformação, como são os casos aqui apresentados.

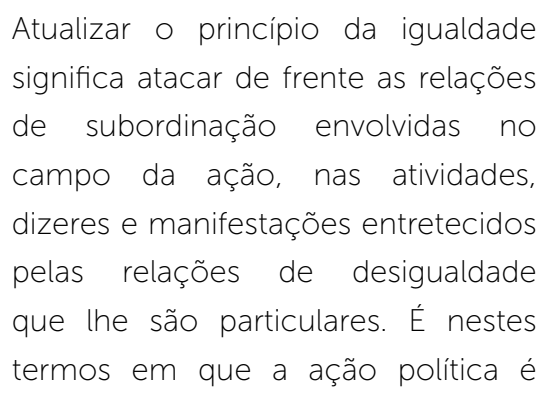

\begin{abstract}
associada a uma política igualitária, que redundaria em redistribuição do sensivel. (PALLAMIN, 2010, p.8)

Nada é em si mesmo político, mas pode tornar-se político à medida que opera sob a racionalidade dissensual. (...) ações serão políticas quando forem fundamentadas pela interrupção, em certo domínio, das relações desigualitárias em vigor. (PALLAMIN, 2010, p.8-9)
\end{abstract}

O que verificamos e exploramos, é que as práticas dos arquitetos, podem ser consideradas como dotadas de valor estético, na medida em que se aproximam das necessidades dos moradores de favelas, funcional e esteticamente e nisso há um sentido político transformador. Esse valor está, no entanto, mais no processo do que no projeto ou no próprio resultado que, muitas vezes, dadas todas as condicionantes não se viabiliza na maneira projetada.

Assim como com a componente estética, também a componente técnica do trabalho do arquiteto militante, se traduz numa ação que tenta evitar a imposição, a correção, o autoritarismo.

$\mathrm{Na}$ favela, o arquiteto militante reconhece a necessidade de intervenção, mas ao mesmo tempo, a necessidade de se transcender no uso das técnicas, no sentido de valorizar e "aproveitar" o que já existe no território e as soluções concretizadas pelos 
seus moradores (ou por intervenções anteriores), ou procurando soluções alternativas às comumente estabelecidas para melhor adaptação à "natureza” daquele lugar.

$\mathrm{Na}$ aplicação da técnica, o arquiteto militante em favelas, se coloca numa posição de constante aprendizado através da acumulação de experiências ou na procura por referências, mas também numa reflexão sobre a (re)aplicação das técnicas, para encontrar a mais adequada solução para aquela favela específica, que é diferente da anterior.

Neste uso da técnica, encontramos uma expressão política, que transparece mais no processo do que na própria solução, que, como referimos, muitas vezes acaba por não ser materializada. Mas esta atitude de pesquisa e reflexão técnica do arquiteto militante perante a favela e seus desafios convida à transformação da própria arquitetura e urbanismos, suas técnicas e tecnologias, no sentido do pioneirismo, vanguardismo e inovação.

A história de atuação de arquitetos em favelas lembra-nos que a criação de parâmetros, legislação e técnicas de atuação, é profundamente enraizada em experiências associadas à militância progressista. É o caso da integração das ZEIS (Zonas Especiais de Interesse Social) em Planos Diretores Municipais a partir das experiências dos governos municipais progressistas no período da redemocratização, dos próprios PLHIS (Planos Locais de Habitação de Interesse Social) tornados obrigatórios pelo Ministério das Cidades criado pelo ${ }^{o}$ governo federal petista, a legitimidade da importância do processo participativo reivindicados por técnicos sociais e representantes da sociedade civil organizada, ou a definição de medidas mínimas de intervenção e de consolidação de assentamentos precários, que garantam a habitabilidade, salubridade e acessibilidade, de soluções inovadoras para contenção geotécnica ou possibilidades de calçamento e desenho de ruas diferentes das usadas na restante cidade, também propostas habitacionais incomuns ou de intervenção no território autoconstruído - os projetos de melhorias habitacionais. Nem todos, mas muitos deles podem ser atribuídos a técnicos (e também sociedade civil) que experimentaram e demonstraram que no seu uso, os paradigmas da produção de uma cidade injusta poderiam ser alterados. Alguns destes exemplos serão abordados nos casos analisados adiante nesta pesquisa.

Infelizmente estamos longe de alcançar a ampla aplicação de algumas conquistas. No seu reflexo prático sobre o território, são muitas vezes cooptadas por interesses que se revelam menos sociais, menos justos e democráticos, e a sua materialização ainda é escassa ou parcamente alcançada. Mesmo nestas condicionantes encontramos sujeitos insistindo na sua exploração e aplicação. Os sujeitos militantes reconhecem os limites e contradições da sua atuação. Ainda assim, 
têm contribuído e contribuem através das suas práticas, para a criação de um campo de conhecimento que objetiva a transformação social e territorial.

Mesmo que com um foco direcionado apenas para a atuação de assessorias técnicas em urbanização de favelas, compartilhamos com Pulhez, alguma esperança (e o encontro de referências) na atuação destes sujeitos: os arquitetos militantes.

Nesse sentido, os arquitetos cujas trajetórias e experiências aqui iluminamos, mais do que 'militantes' do ofício, são sujeitos que, em sua prática cotidiana, certamente técnica e certamente política, se mobilizam pela própria capacidade de criticar a si próprios, de perceber limitações e incongruências legítimas. Muitos deles procuraram enfrentar (e vêm enfrentando) esses impasses também em reflexões acadêmicas e em outros territórios de atuação. É grande, por exemplo, o número de arquitetos que passaram pelas experiências movimentistas dos anos 1980 e início dos 90 e que vem procurando registrar erros, acertos, ganhos e perdas desse período como forma de (re)pensar seus próprios limites e ações incompletas, mas também de admitir que, quando

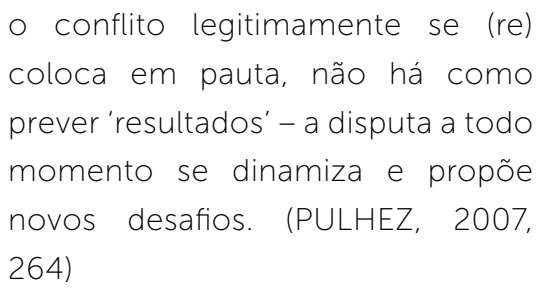

Nas experiências aqui estudadas observamos como estes limites burocráticos, tecnológicos, físicos e sociais, ou outras condicionantes, levam a processos marcados por escolhas e decisões dentro de contingências e concessões. E como, em Urbanizações de Favelas, os resultados ainda estão aquém dos projetos idealizados.

Como tal, é nos próprios processos que encontramos a demonstração de um tensionamento mais fiel entre ética, técnica e estética nas práticas dos arquitetos militantes. Por isso a análise de processos é privilegiada nesta pesquisa. Mais do que obras fiéis às concepções projetuais dos militantes, encontramos coerência no amadurecimento processual e projetual, nas reflexões e concepções sobre urbanização de favelas, em cada um dos militantes estudados ao longo do seu percurso profissional que tem sido, por cada um deles, permanentemente revisado e criticado.

Passemos ao enfoque sobre os processos de urbanização de favelas e à sua contextualização histórica, política e programática, para que possamos 
analisar a partir das condicionantes e seus referenciais, as práticas de processo e da militância em seus limites e alcances, dentro da arquitetura e urbanismo na urbanização de favelas. 

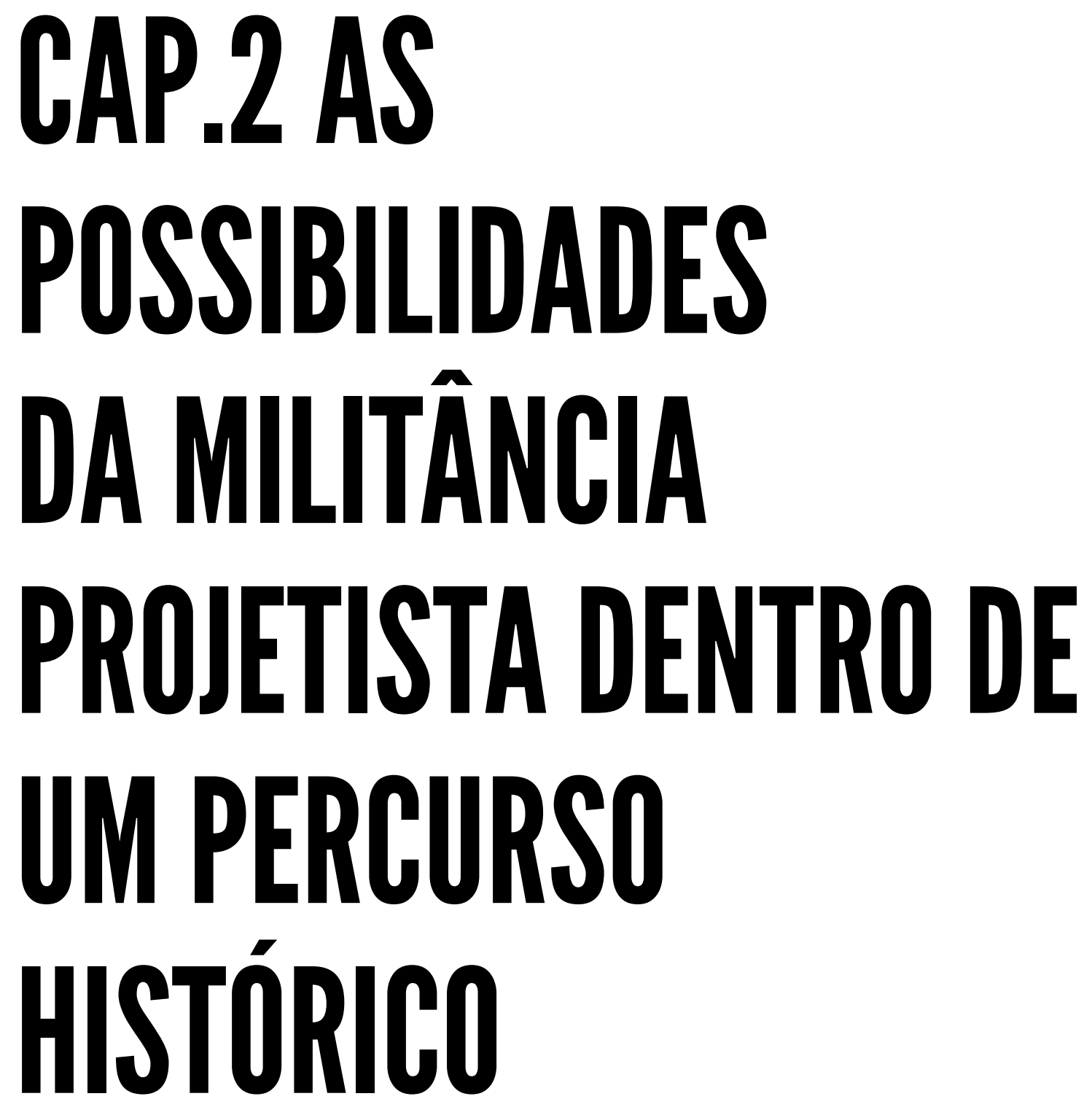

A retrospectiva histórica da Urbanização de Favelas no Brasil tem sido descrita e analisada em trabalhos teóricos sobretudo a partir dos anos 2000. Vejamos LabHab (I 999), Bueno (2000), Denaldi (2003), Samora (2009), Petrarolli (20 I 5 ) entre outros. Estes têm versado sobretudo na reflexão sobre políticas, programas e parâmetros de intervenção. Encontramos algumas produções que se debruçam sobre as questões projetuais/processuais como é o caso de algumas reflexões sobre programas específicos e projetos nesse contexto.

Como já referimos, Pulhez (2007) traça o histórico de urbanizações no Brasil destacando a relação e a ação de arquitetos em favelas, e se debruçando sobre práticas participativas, de relação próxima da horizontalidade em experiências entre moradores e técnicos de arquitetura e urbanismo. $\mathrm{Na}$ dissertação de mestrado (2007), aprofunda na análise sobre 3 exemplos de urbanização de favelas desenvolvidos por assessorias técnicas em São Paulo. 
Partindo desse pressuposto, mas ampliando-o propomos aqui apresentar uma breve retrospectiva histórica da Urbanização de Favelas iluminando alguns dos casos que definimos como militantes e que ilustram esta reflexão. A militância, como aqui a definimos, ultrapassa as experiências e metodologias de participação, apesar de, na maioria dos casos, essas serem parte fundamental destes processo. Nesta retrospectiva pretendemos contextualizar esta militância e apresentar em que medida a consideramos militante.

Os sujeitos e os processos selecionados destacam-se em algum aspeto do seu contexto político e programático, indo, na maioria dos casos, no sentido oposto ao que se estabeleceu na sua época como intervenção em favelas. Apresentamos os casos iluminando esses aspetos ou particularidades procurando desta forma redigir uma linha de tempo sobre a militância na urbanização de favelas no contexto brasileiro, focado ainda nas regiões metropolitana de São Paulo e municipal do Rio de Janeiro, com as ampliações de panorama nacional quando se tornar pertinente. Propomos uma organização por períodos, agrupando-os em contextos político-programáticos e de forma de intervenção consensual semelhante, para que, nesses contextos possamos mais claramente identificar e iluminar as contribuições ou dissidências no sentido militante, dos casos de estudo que apresentamos. As posturas, ações, ferramentas ou metodolo- gias destes processos e que caracterizamos como militantes serão aprofundadas no próximo capítulo, deixando aqui apenas a sua contextualização histórica.

Como já referimos a compreensão e concepção de urbanização como política e prática de intervenção em favelas, foi apropriada e desenvolvida por diferentes sujeitos inclusive em gestões mais conservadoras. Mas a Urbanização de Favelas como aqui nos propomos abordar, trata-se de uma reinvindicação progressista e militante. São processos que arriscam a possibilidade de permanência de determinada população no local onde se estabeleceu, para que, após a intervenção adquiram a qualidade de vida que não tinham total acesso, no sentido da infraestrutura básica urbana, da integração aos serviços e à total inter-relação com a dinâmica social da cidade. Uma intervenção no sentido de tornar o território e a sociedade mais igualitária, justa e emancipadora. Esta tem sido a luta de alguns Movimentos Sociais por Moradia, mas também de técnicos e academicistas conscientes das discrepâncias territoriais existentes nas cidades brasileiras. Estes atores fazem também parte da história da atuação militante em Urbanização de Favelas. Reconhecendo o seu valor e contributo, propomos, nesta exploração um foco direcionado para aqueles que utilizaram o seu ato técnico de leitura territorial, de desenho, projeto, do arquiteto e urbanista no sentido de uma ação militante. 
Verificamos que esta concepção como uma intervenção integrada em favelas é resultado de um acúmulo de conhecimento retratado por autores alguns dos quais acima referidos. A luta pela intervenção em favelas tem-se transformado tal como a concepção de cidade e de direitos. Se num primeiro momento a reivindicação principal era pela permanência, e contra a remoção, as exigências assim como a concepção da intervenção se tornaram mais sofisticadas, e hoje quando pensamos em Urbanização de Favelas assumimos tratarse do complexo processo que contempla inúmeras disciplinas de intervenção, desde as físicas às sociais.

No entanto, são poucos os casos que conseguimos enumerar em que após a intervenção, temos uma favela urbanizada totalmente e parte da chamada cidade formal. Na maioria dos casos, as urbanizações têm sido as intervenções possíveis dados os limites orçamentários, programáticos, jurídicos, das próprias gestões públicas, ou dentro das características físicas do próprio assentamento. Noutros casos, as complexas dimensões sociais não chegam a se apropriar da intervenção, por esta não ser, desde o seu princípio, adequada, ou pela transformação dos contextos sociais em constante dinâmica. Há ainda os casos da manutenção ou agravamento da informalidade e precariedade, mesmo após a intervenção, por diversos fatores, mas sobretudo por uma ausência de representação e "controle" (social e urbanístico) do poder público (NAKAMURA, 20 I 4). Por fim, a questão cultural de preconceito pejorativo que envolve os territórios urbanos de informalidade desde o seu aparecimento, tem sido uma das características, que mantém estes como territórios marginalizados, mais difícil de superar.

Uma parte desse caminho foi conquistado por técnicos revolucionários que na sua e com a sua atuação questionaram o que lhes era proposto como forma de intervenção em favelas. Reconhecendo elos de ligação entre ações e sujeitos militantes, a influência de aprendizado de uns com os outros, propomos aqui montar uma rede de relações entre estas experiências que aconteceram em São Paulo e no Rio de Janeiro. A história que contamos é uma pequena parte da história de Urbanização de Favelas no Brasil, focando em apenas uma parte dos técnicos, os arquitetos projetistas militantes e algumas das suas experiências, mas que assumimos tratar-se de uma mostra representativa dessa mesma ação ou postura de trabalho. É essa a história que passamos a apresentar, contextualizando os casos e sinalizando a justificativa da sua escolha.

Exploramos um levantamento sobre experiências recentes, mas onde os sujeitos reconhecem a transformação das técnicas utilizadas ao longo do tempo, e também a influência dos diferentes contextos históricos. Recorremos portanto às experiências relatadas por sujeitos vivos, umas mais recentes e outras de início das suas carreira. Neste quadro, decidimos recuar até à experiência de Brás de Pina, projeto dos Quadra Arquitetos no Rio de Janeiro, pelo seu significado histórico como experiência de Urbanização de Favelas, mas também pelo seu pioneirismo no que diz respeito à militância, tornada experiência pública (com financiamento público), sobretudo no contexto em que aconteceu (início da Ditadura Civil-Militar). A inclusão desta experiência também é resultado dos depoimentos que recolhemos. Os arquitetos, sobretudo os de atuação no Rio de Janeiro, reconhecem no arq. Carlos Nelson Ferreira dos Santos e na sua prática profissional e social uma referência e influência. 


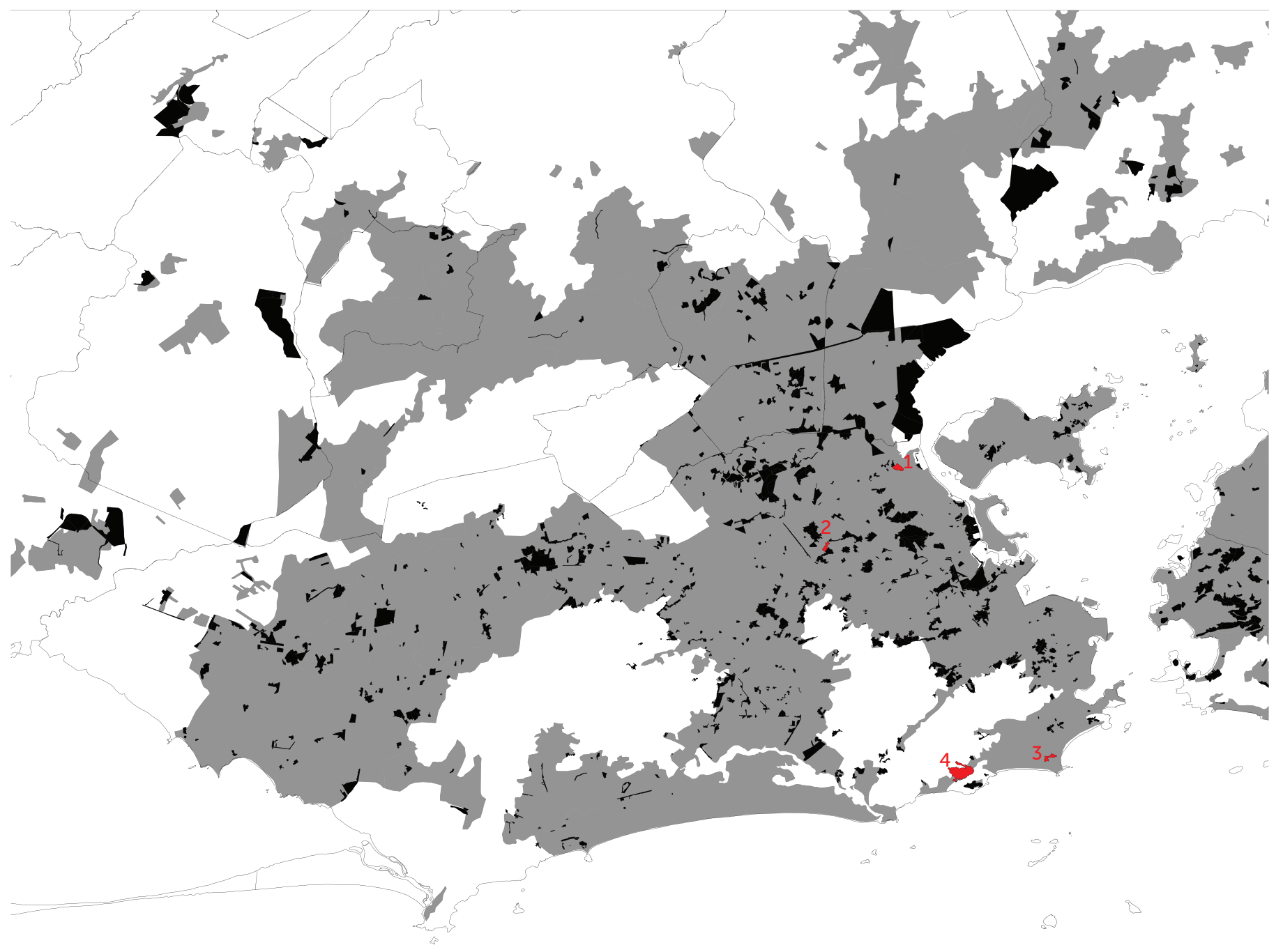

1. Brás de Pina

2. Serrinha

3. Cantagalo e Pavão-Pavãzinho

4. Rocinha

MAPA 1 - Localização dos casos de estudo a Região Metropolitana do Rio de Janeiro.

Limites dos Municípios, Mancha Urbana e Assentamentos Precários.

Créditos: Bárbara Muhle, sob coordenação da autora.

Base: Assentamentos Subnormais IBGE (2016. 


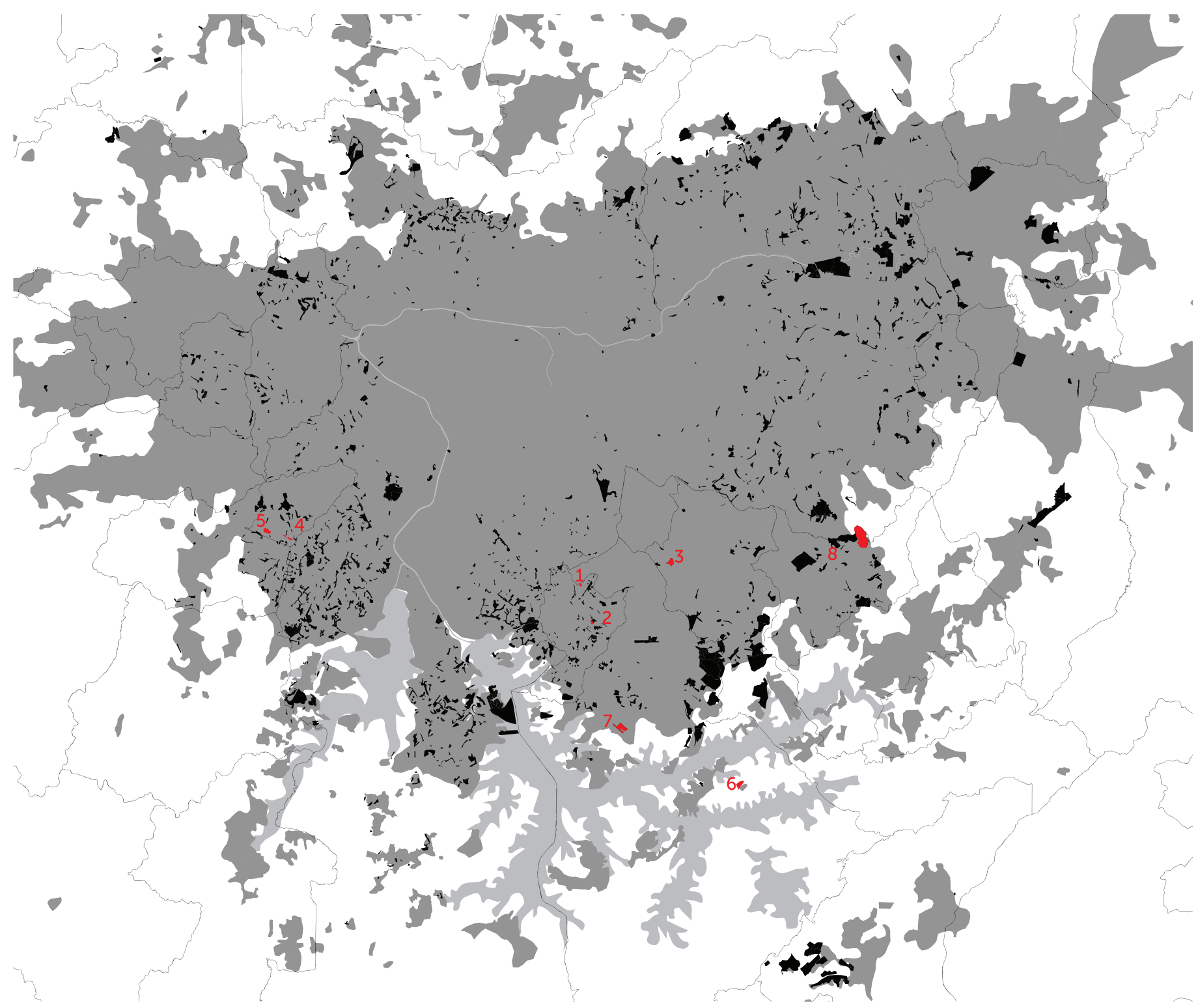

1. Dom João VI, Diadema

2. Vila Popular, Diadema

3. Tamarutaca, Santo André

4. Jardim Sílvio Sampaio, Taboão da Serra
5. Jardim Santo Onofre, Taboão da Serra

6. Capelinha e Cocaia, São Bernardo do Campo

7. Batistini, São Bernardo do Campo

8. Chafik-Macuco, Mauá

MAPA 2 - Localização dos casos de estudo a Região Metropolitana de São Paulo.

Limites dos Municípios, Mancha Urbana e Assentamentos Precários.

Créditos: Bárbara Muhle, sob coordenação da autora.

Base: Assentamentos Subnormais IBGE (2016). 


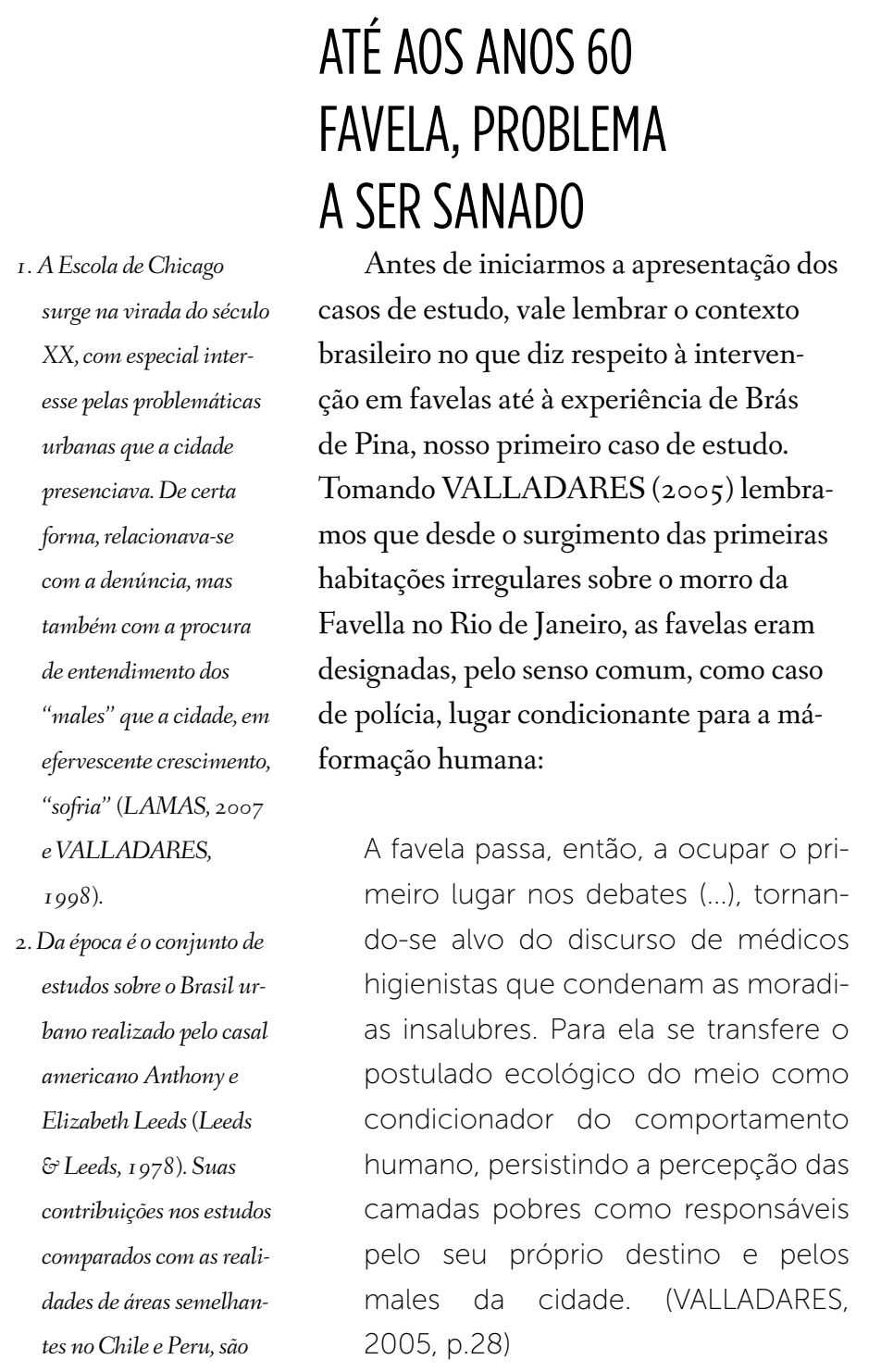

referência ainda hoje no campo dos estudo sociais. (PULHEZ, 2007)

\section{A forma mais comum de intervenção} era a erradicação com sentido higienista $\mathrm{e}$ gentrificador, sem propostas direcionadas para a sua resolução pois, na verdade, pouco era o aprofundamento na compreensão do fenômeno.

O interesse por estudos sobre a favela e sua população surge com maior afirmação nos anos 60 num contexto onde a academia, sobretudo as ciências sociais, se vêm influenciadas por correntes de pensamento globais. Manifesta-se a influência de correntes como a Escolas Chicago ${ }^{1}$ e de estudos sob influência marxista onde sobressaem as análises sobre as relações de classe, e uma classe privilegiada e acadêmica procura a aproximação às classes trabalhadoras, mais desfavorecidas, que nas cidades brasileiras se encontram, em grande parte, morando em territórios de exclusão, entre eles as favelas, que surgem e crescem nesse contexto.

Deste período identificamos algumas experiências de maior relevância, algumas das quais ligadas ao conhecimento da realidade mais do que com sentido propositivo em si como é o caso das pesquisas SAGMACS ( i 960), ou, já nos anos 6o, as pesquisas organizadas por Perlman ( 1977 ) e pelo casal Leeds². De citar algumas experiências de atuação como o SERFHA - Serviço Especial de Recuperação das Favelas e Habitações Anti-Higiênicas no Rio de Janeiro e o MUD - Movimento Universitário de Desfavelamento em São Paulo, ambos assessorias de sentido assistencialista e próximos de uma atuação da Igreja Católica na sua ala progressista da época. Como experiência tecnológica PULHEZ (2007) lembra-nos do Cajueiro Seco em Pernambuco, desenvolvida por Acácio Gil Borsói, em parceria com atores e conhecimento populares. Situamos nesta época também a atuação de Arthur 
$\operatorname{Rios}^{3}$ no Rio de Janeiro e o consequente fortalecimento de movimentos organizados de moradia o que terá repercussão nos anos seguintes.

Apesar da influencia destas experiência (e outras semelhantes) sobre alguns técnicos contemporâneos, a classe de arquitetos e urbanistas não se focava nas formas populares de habitação, a atenção estava direcionada para o crescimento urbano como um todo, se bem que com a consciência da territorialização das problemáticas advindas de uma sociedade de exploração, e no caso, um país de periferia do capitalismo (MARICATO, I 995). A pauta do Quitandinha' 63 - encontro de arquitetos e urbanistas organizado pelo Instituto dos Arquitetos Brasileiros (IAB) - evidencia esse foco no seu chamamento: Seminário de Habitação e Reforma Urbana. Nas discussões marcadas tanto pelas influências modernistas como pós-modernistas reconhece-se a necessidade de uma produção habitacional acessível para os mais pobres, mas que deveria ser enfrentada dentro de uma atuação desenvolvimentista (PULHEZ, 2005, p.58-59), e sobre a qual se pode assentar a justificativa para o maior programa habitacional brasileiro do séc. XX como veremos a seguir.

\section{4-1985 \\ DITADURA CIVIL-MILITAR. BNH, REMOÇÕESE REALOCAÇ̃̃ES}

No sentido oposto a este período emancipatório e revolucionário (e talvez inclusive contra ele) deu-se em I 964 o Golpe Militar e com ele o início de um período de 2 I anos de Ditadura e repressão. O Regime serviu-se de justificativas modernistas, de produção em massa, dentro da lógica 'central-desenvolvimentista', para a criação do maior programa até então de produção de habitação popular, o Banco Nacional de Habitação - BNH. A sua concretização demonstrou-se, pelo contrário, conservadora, gentrificadora, repressora. Pelo BNH foram produzidos e reproduzidos conjuntos habitacionais fadados ao fracasso, dada, na sua grande maioria, a ausência de relação com a cidade já construída, serviços ou comércio e afastados dos lugares de origens das populações destinatárias. Mas a principal crítica a esta experiência nacional foi a inacessibilidade da população mais podre e portanto mais necessitada de moradia adequada. À parcela da população com renda inferior a 3 salários mínimos continuava a destinar-se as formas irregulares, inseguras e precárias de moradia em favelas ou loteamentos clandestinos. ${ }^{4}$ (BONDUKI, I 998)

Numa época de grande repressão política, sobretudo depois de $1968^{5}$ e pelo menos até ao começo dos anos $80^{6}$, são poucos os casos que conseguimos enumerar de ação militante no campo da habitação de interesse social, sobretudo da ação em favelas. A principal intervenção do Governo em todas as suas instâncias, para a "solução
3. Para além de ter coordenado a pesquisa Aspectos Humanos da Favela Carioca (Sagmacs, I 960), o socioólogo José Arthur Rios, encabeçou o SERFHA entre 1960-1962, abrindo a possibilidade de aproximação entre um organismo público e os moradores de favela.

Rios passa a ser considerado referencia no fortalecimento e assessoria de movimentos sociais organizados no Rio de Janeiro.

4. Entre os anos 7 o e 8 o dáse a explosão demográfica e de ocupação urbana territorial nas cidades brasileiras. Em São Paulo as populações mais pobres vão morar no centro da cidade em cortiços, mas começa a alastrar a comum morfologia urbana de 'loteamentos clandestinos' periféricos. (BONDUKI, I998)

5. Em 1968 deu-se o Ato

Intitucional $n_{5}^{\circ}(A I-5)$, que passou a definir a atuação mais repressora do Regime em vigor.

6. Nos anos 8o, antes do fim da Ditadura Militar inicia-se um periodo de democratização por todos o país, com movimentos exigindo aumento de participação política, entre eles movimentos de bairros populares e de luta por moradia. 
fig. 1 Brás de Pina antes da Urbanização (anos 60) Fonte: fotografia de Antony Leeds.

7.Os grandes conjuntos

habitacionais construidos sem planejamento e integração urbana, são até hoje questionados na sua forma de implantação e consequência sobre as populações neles alojada. Vila Aliança e Vila

Kennedy foram dois dos conjuntos habitacionais construidos para receber populações de favelas removidas do Rio de Janeiro, inclusive de Brás de Pina, durante o governo de Carlos Lacerda, $e$ com o apoio de recursos internacionais $(S A N$ TOS, ${ }_{198}$ I, p.88).

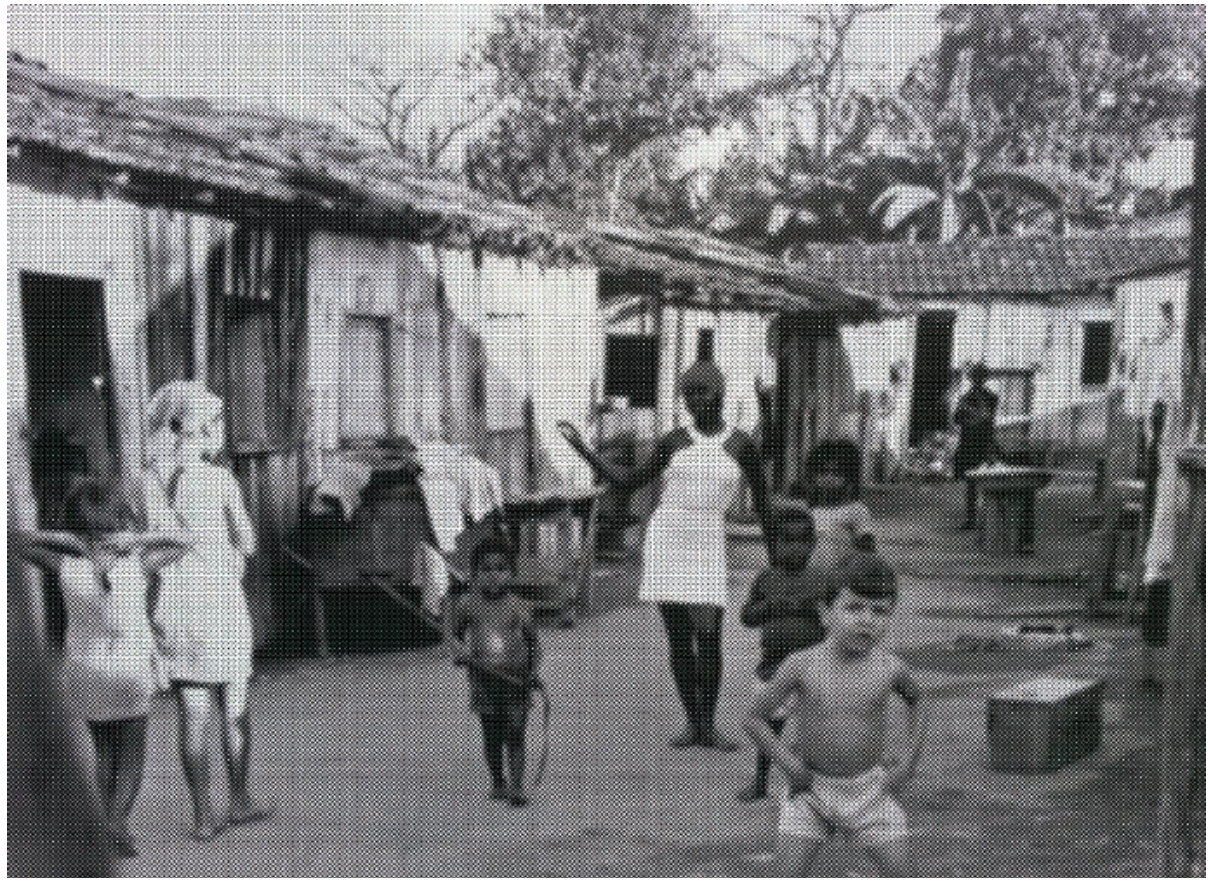

do problema" das favelas manteve-se na erradicação e remoção das populações para lugares distantes, como é o caso dos conhecidos de Vila Aliança e Vila Kennedy ${ }^{7}$ no Rio de Janeiro.

\section{9-1973 BRÁS DE PINA, QUADRA ARQUITETOS, RIO DE JANEIRO}

Foi a partir da reação contra a remoção de uma favela destinada a ocupar as Vilas Kennedy, Aliança e Esperança, que o nosso primeiro caso de estudo se iniciou. Brás de Pina é uma comunidade na zona norte do Rio de Janeiro e na época, umas das favelas a remover e realocar em conjuntos habitacionais afastados, em pleno Governo de Carlos Lacerda ${ }^{8}$. A comunidade, apoiada por movimentos religiosos e respaldada em parte pela mídia, resistiu quase na sua totalidade à remoção no final de 1964 (SANTOS, I 98 I , pg. 32). Com a mobilização da Associação de Moradores, o apoio da FAFEG - Federação das Associações de Favelas do Estado da Guanabara, e assessoria dos (então estudantes universitários) integrantes da Quadra Arquitetos, foi proposto um plano alternativo à remoção e que garantisse a permanência. Mas só em I 968, com a troca a governo estadual e a criação da CODESCO - (Companhia de Desenvolvimento de Comunidades ${ }^{9}$, a Quadra Arquitetos é contratada oficialmente como projetista da urbanização da favela Brás de Pina. Os episódios que marcaram esta experiência (pelo lado dos técnicos) estão amplamente detalhados em SANTOS ( 198 г ) e BLANK (1977).

O caso é emblemático por se tratar da primeira situação onde a associação entre técnicos, moradores e poder público garantem a permanência e uma ação pública no sentido de melhorias urbanas e habitacionais. $\mathrm{O}$ caso destaca-se ainda mais considerando a sua data e local. A intervenção em Brás de Pina é contemporânea e num sentido completamente oposto ao expoente de atuação do $\mathrm{BNH}$ e, no Rio de Janeiro, do CHISAM - Coordenação de Habitação de Interesse Social da Área Metropolitana do Grande Rio, um órgão público, também estadual, criado para promover a remoção de favelas da cidade. 
A ação da CHISAM foi notável, chegando em três anos a remover $28 \%$ da população favelada do Rio (CHISAM, 1971, p.69). (SANTOS, 1981, pg. 50)

A justificativa de enquadramento deste como o primeiro caso referência de militância em Urbanização de Favelas estava dada pela ação revolucionária conjunta entre comunidade e técnicos, mas a postura e ação militantes dos integrantes da Quadra Arquitetos ultrapassaram mais do que apenas este desafio.

Na sua atuação, pautada por uma mobilização política consciente, os jovens arquitetos fizeram propostas e ações ousadas que nem sempre foram aceites pela população ou pelos técnicos do poder público, aos quais tinham obrigatoriedade de resposta. O projeto foi desenvolvido com uma presença em campo constante, presença essa que se iniciou num diagnóstico aproximado da comunidade. O projeto urbanístico foi amplamente discutido com a população e seus principais interlocutores. Os projetos habitacionais foram feitos com assessoria para cada família, contemplando os desejos e até os desenhos de cada uma. Nas propostas mais ousadas e, talvez por isso, não aceites, destacamos a marcação coletiva de lotes, através de condomínio horizontal, com o intuito de prever a possibilidade de verticalização da ocupação (SANTOS, I 98 I, pg. 64) e a permissividade no repas- se/venda dos direitos dos imóveis recebidos por financiamento público, compreendendo a possibilidade de mobilidade social ou física das famílias (SANTOS, I 98 I, pg. 72 74). A primeira foi recusada pelos próprios moradores, a segunda foi envolta em grandes discussões entre técnicos, moradores e poder público, este último se recusando a aceitar a proposta (SANTOS, I 98 I, pg. 64, 74-75).
8. "Foram construidas I 2 min unidades para receber as populações das favelas do Pasmado, Esqueleto, Maria Angu, João Cândido e Brás de Pina (dados fornecidos pela CEHAB-RJ)." (SANTOS, I 98 I, pg.88) 9.A CODESCO surge

como resposta à

demanda e promessa de campanha do governo de Negrão Lima, que ao contrário do seu antecessor, Carlos Lacerda, não encarava a questão de remoção de favelas como bandeira política. O organismo surge como uma resposta para o diálogo à insatisfação das remoções na cidade, propondo-se na "integração dos aglomerados subnormais na comunidade normal adjacente, intervindo nos aspectos urbanisticos, habitacionais e outros necessários" (CODESCO, apud SANTOS, I 98 I, p.56). 


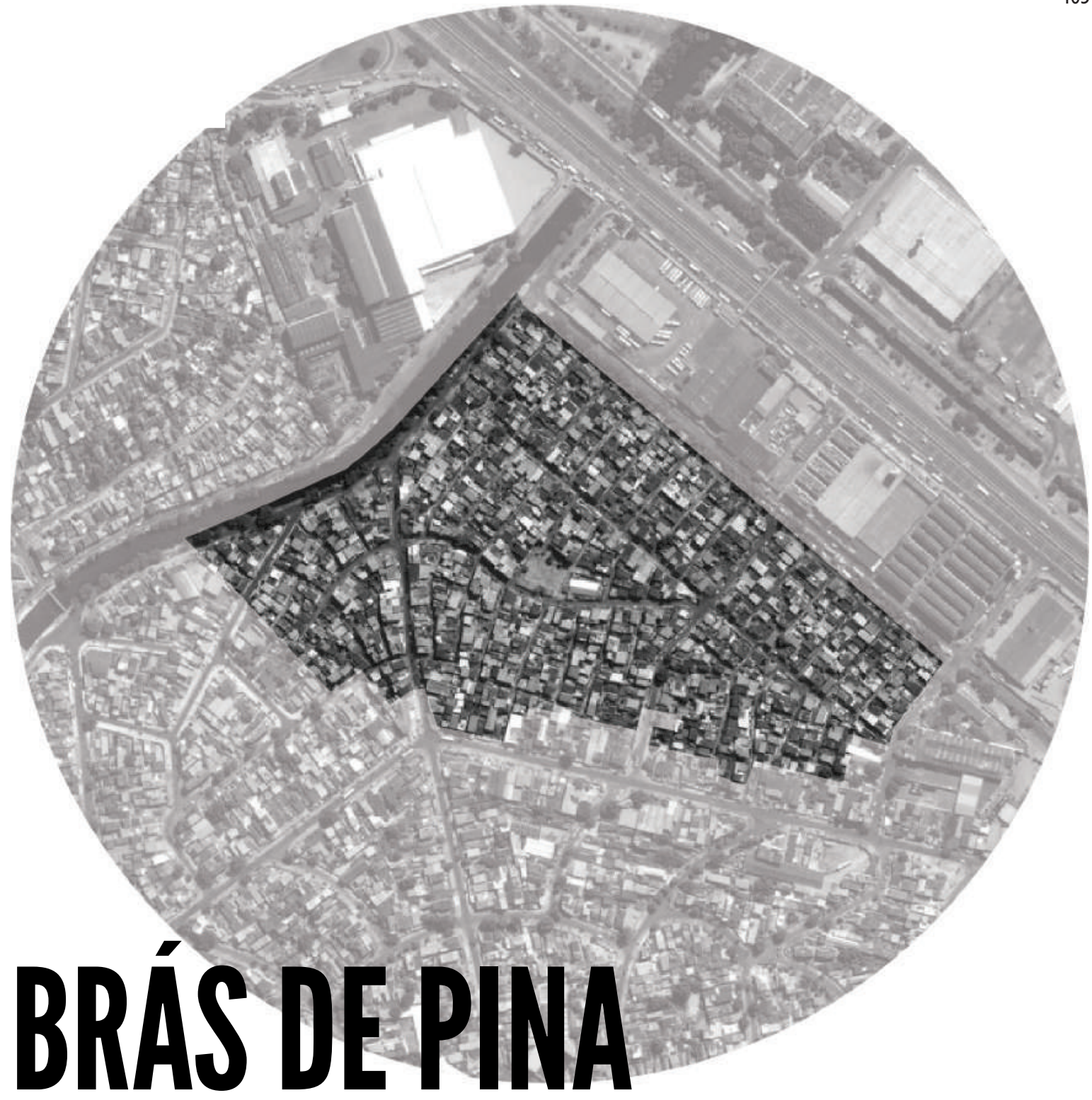

Localização: Rio de Janeiro

Data: 1968 - 1971

População: 892 Famílias

Área: $108.359 \mathrm{~m} 2$

Projetista: Quadra Arquitetos

Agente Organizador: Associação de Moradores, FAFEG e Companhia de Desenvolvimento de Comunidades - CODESCO Agente Financiador: CODESCO - BNH

Outros agentes: Associação de Moradores

Escopo: Levantamentos, plano urbanístico e habitacional e acompanhamento de obra.

Breve descrição: Processo que procurou ser participativo através do diálogo com a população e suas lideranças. O plano de intervenção consistiu no remanejo e redesenho do parcelamento do solo e implantação de vias públicas e respectivas redes. As habitações e sua construção eram da responsabilidade do morador, mas houve a disponibilidade de assessoria técnica para a definição de cada uma das casas. Ficava a critério do morador usar ou não essa assessoria.

Atividades realizadas: Levantamento, diagnóstico, projeto urbanístico com reparcelamento de solo, assessoria técnica para a construção das moradias

Observações: Brás de Pina é uma das experiências pioneiras de urbanização de favelas no Brasil, que contemplam a luta pela permanência e contra a remoção dos seus moradores, e o seu financiamento via poder público. 


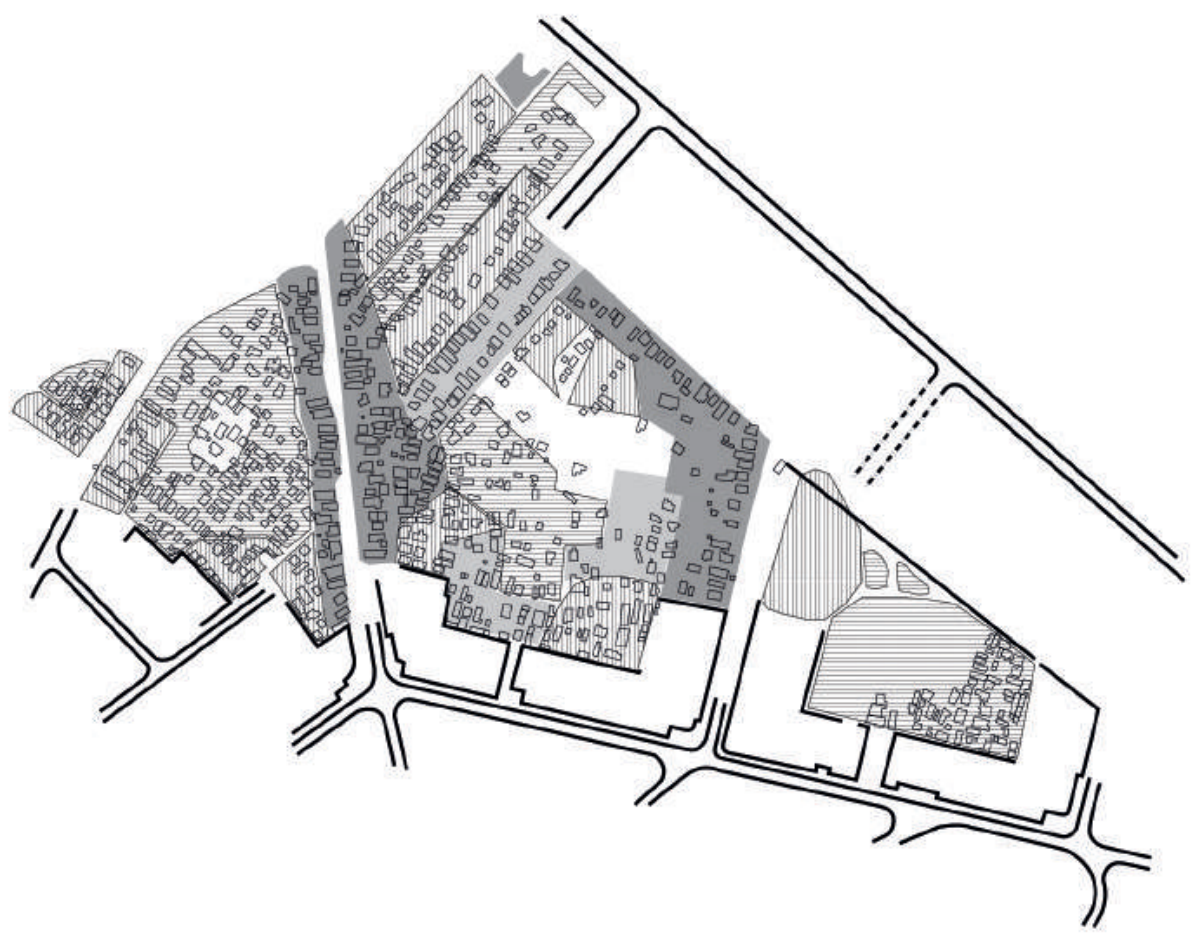

Legenda

\section{Síntese de Levantamento e Diagnóstico de Brás de Pina}

Desenho realizado sobre bases projeto elaborados por Quadra Arquitetos. Na comparação entre as sínteses verifica-se a transformação do território, num reparcelamento regularizado. No entanto, as vias estruturais mantêm a sua localização, havendo, a partir delas a subdivisão de quadras e lotes. Esta definição possibilitou também a implementação do projeto por fases, numa relocação interna de moradias e famílias.

Elaboração: Beatriz Nobumoto sob coordenação da autora

Fonte base: BLANK, 1977

(página anterior: Destaque de favela Brás de Pina sobre fotografia aérea atual, Google Earth, 2016. Elaboração: Bárbara Muhle sob coordenação da autora) 

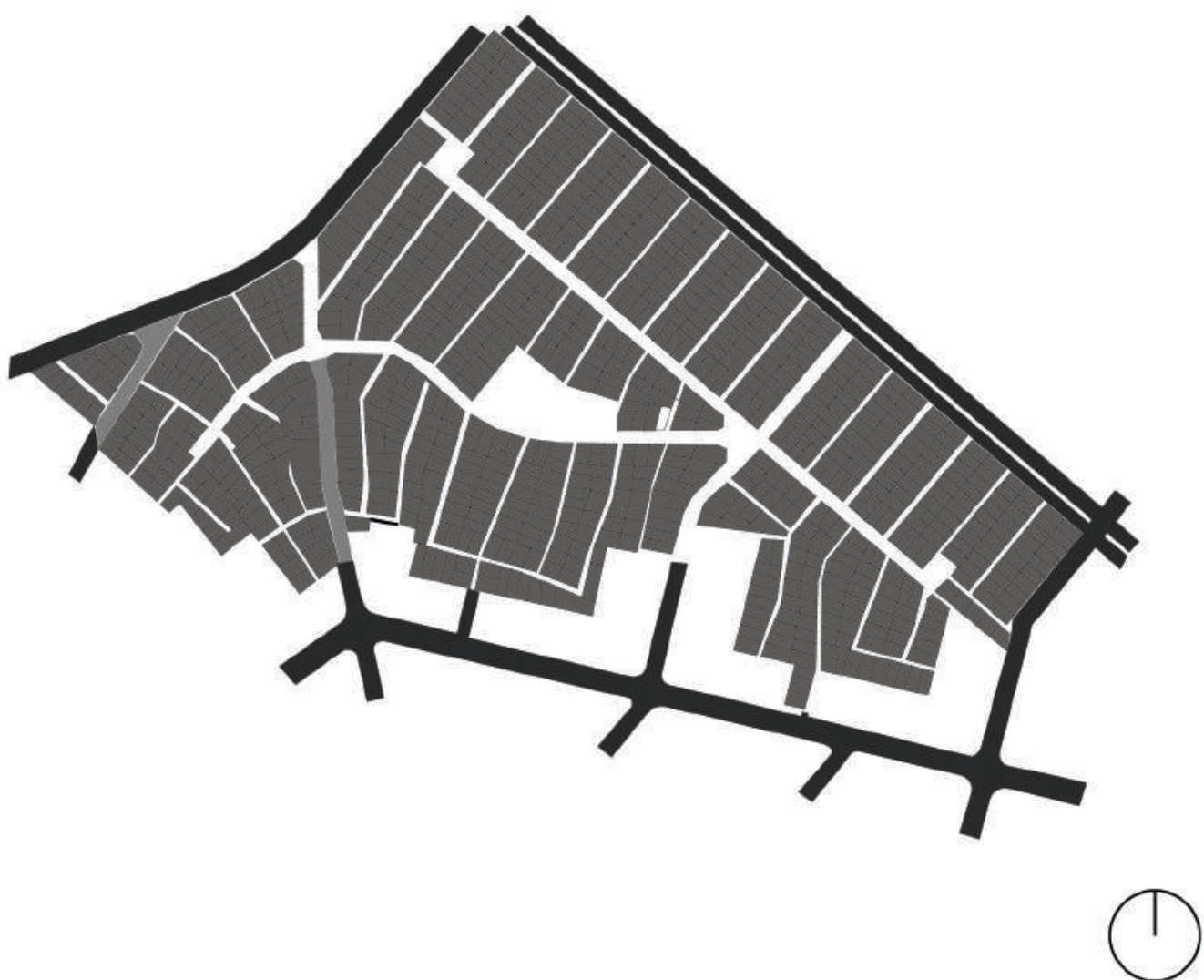

Legenda

Novos Lotes Habitacionais

Circulação de Veiculos

Circulaçăo de Pedestres

100

$200 \mathrm{~m}$

\section{Síntese de Projeto Final de Brás de Pina}

Desenho realizado sobre bases de levantamento e diagnóstico elaborados por Quadra Arquitetos. Na comparação entre as sinteses verifica-se a transformação do território, num reparcelamento regularizado. No entanto, as vias estruturais mantêm a sua localização, havendo, a partir delas a subdivisão de quadras e lotes. Esta definição possibilitou também a implementação do projeto por fases, numa relocação interna de moradias e famílias.

Elaboração: Beatriz Nobumoto sob coordenação da autora

Fonte base: BLANK, 1977 


\section{ANOS $80 / 90$ OS PIONEIROS NA GESTÃO PÚBLICA}

Brás de Pina foi das poucas experiências públicas e militantes de que há relato no período entre o Golpe Militar e o início da década de 80 . No final da década de 70 o descontentamento popular com o Regime começou a surtir efeito, e o Governo propôs algumas medidas que se aproximam da forma de morar dos mais pobres, foram criados os programas PROFILURB e PROMORAR. Estas propostas mantiveram o seu alcance aquém das reais necessidade da população de baixa renda brasileira.

Os programas PROFILURB e PROMORAR foram instituídos para atender a população de menor renda. O PROFILURB, criado em 1975, viabilizou a criação de lotes urbanizados e embriões habitacionais destinados à população com renda de 0 a 3 salários mínimos. Até o final de 1980 , menos de 43.000 lotes haviam sido financiados no âmbito do programa PROFILURB em todo o país (ANDRADE \& AZEVEDO, 1982).

O PROMORAR, criado em 1979, representou uma mudança na postura oficial do Governo Federal em relação às favelas. Foi o primeiro programa habitacional promovido pelo Governo Federal que admitiu consolidar a ocupação (favela). O programa viabilizava a manutenção da população no local, mediante financiamento para substituição do barraco por casas de alvenaria e para a execução de infra-estrutura urbana.
O programa financiava até 300 UPCs para construção de unidades-embriões de até $25 \mathrm{~m}^{2}$. "O programa executado por empresas construtoras financiou 206.000 unidades em todo Brasil até 1984" (BUENO, 1998)." (DENALDI, 2003, pg. 16)

Com a recessão financeira nos anos 800 Regime entrou num período de descredibilização e as mobilizações sociais começaram a ganhar protagonismo. Manifestações populares por melhores condições de vida e participação política aconteciam um pouco por todo o país e a pressão popular favorece o final do regime em i 985. A favela ainda era olhada como problema e no geral manteve-se a política de remoção ou invisibilidade do assunto, mas alguns atores (academicistas, mas também técnicos e, mais importante, gestores públicos) compreenderam a dimensão do problema nas escalas municipais (e nacional) e a necessidade do seu enfrentamento e intervenção. Lembremos a existência de algumas experiências práticas de iniciativa acadêmica ${ }^{10}$, e que podemos enquadrar dentro de uma mudança de olhar para a questão, mas que não se chegaram a efetivar e generalizar até aos dias de hoje.

Naquele cenário de recessão econômica mas ao mesmo tempo de fortalecimento de lutas sociais, algumas gestões municipais se destacaram nos seus papéis progressistas, aprovando legislações de âmbito social e em
Io. É desta época a

experiência LabHab

da Faculdade de Belas

Artes de São Paulo, já mencionada, que se torna referência para inúmeros outros laboratórios de experimentação prática dentro de faculdades (PULHEZ, 2007).

I I.Entrevista realizada em I 4/I2/2015, São Paulo.

12. Na RMSP detetamos uma rede de profissionais do planejamento $e$ urbanismo, sobretudo os que podem ser considerados progressistas, em diferentes gestões municipais. Isso dá-se pelas habituais mudanças de gestão legitimadas pelas eleições de $4 \mathrm{em} 4$ anos, mas também por se tratarem de técnicos a que é reconhecida a experiência da prática profissional e da gestão pública. Exemplo disso é Milton Nakamura (um dos sujeitos entrevistados) que desde o início da sua 
fig. 2 Favela em Diadema na década de 80 . Fonte: COELHO, 2008

atuação profissional, participou das gestões nos municípios de Diadema, São Bernardo do Campo, Mauá e São Paulo. Valeria uma pesquisa aprofundada sobre o assunto, para compreender em que medida estas flutuações têm permitido $e$ contribuido para a disseminação de práticas $e$ conhecimento.

I 3. Entrevista realizada em I 4/I2/20 I 5, São Paulo.

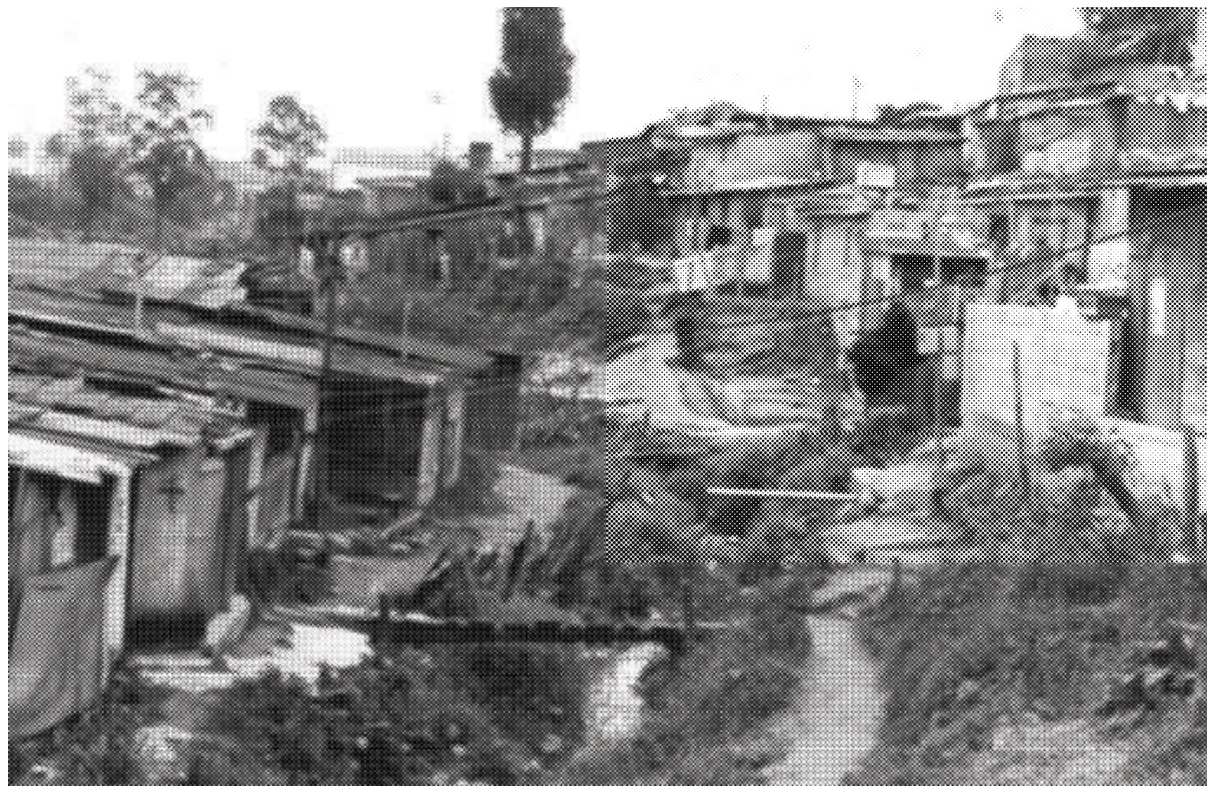

práticas que se aproximaram da população mais desfavorecida, mantida à margem por tanto tempo. As capitais estaduais Belo Horizonte e Recife destacaram-se nas leis que possibilitaram a regularização fundiária de assentamentos até então considerados irregulares, inspiração para a implementação de ZEIS - Zonas Especiais de Interesse Social, e encontramos alguns focos de intervenções pioneiras com recursos públicos e como prática política. De destacar a atuação da gestão municipal de Diadema desde I 983 até I 996, contribuição incontornável no repertório de conhecimento sobre Urbanização de Favelas.

Para além do enfrentamento da necessidade de intervenção estas experiências estabeleceram parâmetros técnicos e pesquisaram possibilidades inventivas posteriormente tornadas referência em processos de Urbanização de Favelas, tais como: dimensões mínimas de lotes e arruamentos, a utilização de componentes prémoldados para a construção de mobiliário urbano, escadas drenantes ou a canalização de córregos, a introdução de tubulação flexível para o abastecimento de água, ou postes metálicos de pequena dimensão para o fornecimento de luz.

\section{3-1996 URBANIZAÇ̃̃ES DE FAVELAS EM DIADEMA, PREFEITURA MUNICIPAL DE DIADEMA, DIADEMA - RMSP}

À gestão municipal de Diadema e à equipe técnica municipal deste período são atribuídas alguns dos parâmetros e das técnicas utilizadas como referência por outras gestões municipais progressistas para a intervenção em favelas. (NAKAMURA, 20 I 5 , informação verbal ${ }^{11}$ ).

Nas primeiras gestões, com uma equipe reduzida mas composta por profissionais engajados (COELHO, 2008), o pioneirismo desta atuação possibilitou o teste da intervenção pública em espaços informais e a formação na prática de diversos profissionais que propagaram as técnicas utilizadas em outros munícipios com as consequentes trocas entre gestões municipais ${ }^{\mathrm{I} 2}$.

O município, um dos mais densos da região, era maioritariamente construído de forma irregular e precária. Em equipes multidisciplinares (social + físico) e por priorização de demanda e organização popular, deslocavam-se para campo, e recorrendo a de Obras), à mão-de-obra disponível ou por mutirão dos próprios moradores, resolviam máquinas da própria prefeitura (Secretaria 


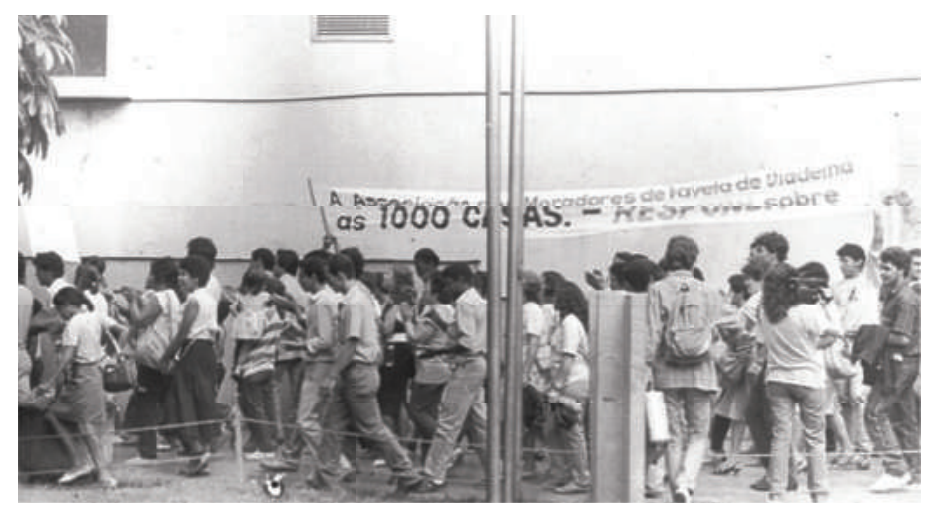

no local as questões físicas de cada favela e asseguravam permanência das famílias assentadas. (NAKAMURA, 2015 , informação verbal $\left.{ }^{13}\right)$

Grande parte das intervenções dava-se por remoção temporária, remarcação de lotes e reassentamento no mesmo espaço das todas as famílias que ali já moravam. O arquiteto Luis Finguerman ${ }^{14}$ estabeleceu para critérios mínimos os lotes de $42 \mathrm{~m}^{2}$ e ruas de $4 \mathrm{~m}$ de largura. Inicialmente, as decisões projetuais eram feitas no canteiro, conforme surgiam os problemas, em obras viabilizadas por sistema de contratação via administração direta. Isso viabilizava intervenções rápidas e eficazes (pelo menos à primeira vista). As intervenções duravam cerca de um ano em cada assentamento (NAKAMURA, 20 I 5, informação ver$\mathrm{bal}^{15}$ ). No final era concedido um documento oficial para cada família que garantia a permanência naquele lote.

[No período de 1989 a 1992,] ocorreram intervenções em 85 favelas, concretizadas em obras de infraestrutura básica, contenções e canalizações de córregos. Foram priorizadas as áreas que não demandavam muitas remoções, alternativa de difícil equacionamento, em face do alto custo e da escassez de terras na cidade. Mais 30 núcleos urbanizados foram beneficiados pela lei de concessão real do uso, em 1992. (COELHO, 2008, p.41)
A inovação da gestão municipal de Diadema deu-se também na compreensão da importância do diálogo interdisciplinar, entre secretarias e inter-setorial, viabilizado a atuação das empresas responsáveis pelo abastecimento de redes como saneamento e eletricidade em espaços que até então estes organismos se recusavam entrar. Para além do fortalecimento de instrumentos de diálogo e participação com a população, foram incentivadas as Associações Regionais de Favela e criado o Fundo Municipal de Apoio à Habitação de Interesse Social - Fumapis, com o respectivo Conselho Gestor. (COELHO, 2008)

Durante as primeiras gestões progressistas em Diadema, e num cenário já de democratização e num contexto favorável para a discussão, é realizado em I 993 O I ${ }^{\circ}$ Encontro Municipal de Habitação, onde são definidas "diretrizes da política habitacional para a cidade em conjunto com a população e representantes dos movimentos sociais de luta por moradia" (COELHO, 2008, p.4 I). fig. 3 Manifestações sociais de luta por moradia. Fonte: COELHO, 2008

I 4. Luis Finguerman foi o arquiteto responsável pela primeira equipe técnica de urbanização de favelas da de Diadema. Antes de chegar à Prefeitura Municipal de Diadema passou por diversas experiências onde podemos identificar na prática o seu caráter militante. As suas experiências profissionais até à chegada a Diadema são relatadas no depoimento dado, à revista Espaços \& Debates, $n^{\circ} 8$ em I 983 (GARCIAe NUNES, I $_{98}$ ). I5. Entrevista realizada em I 4/I2/20I5, São Paulo. 


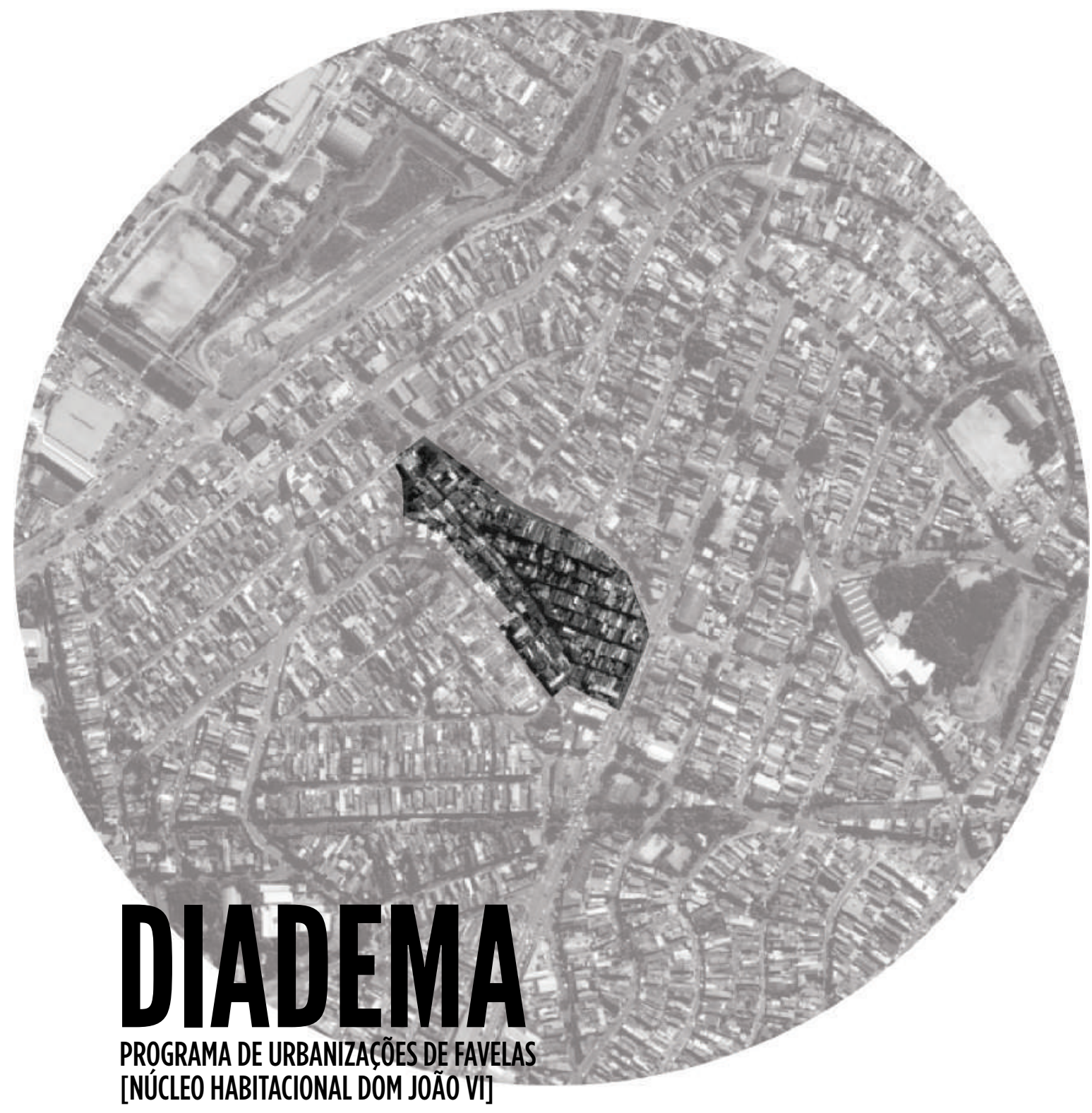

Localização: Diadema - SP

Data: 1983-1996

População: 366 Famílias

Área: $20.681 \mathrm{~m} 2$

Projetista: Prefeitura Municipal de Diadema

Agente Organizador: Prefeitura Municipal de Diadema

Agente Financiador: Prefeitura Municipal de Diadema

Escopo: Estudo Preliminar; Cadastramento; Projeto de Urbanização.

Breve descrição: O programa de urbanização de favelas atuava nas seguintes etapas: i. estudo preliminar, para verificação da viabilidade física e jurídica de consolidação do território; ii. cadastramento: realizado e controlado pelos próprios moradores; iii. projeto de urbanização: o objetivo era destinar um lote (de 42m2) para cada família, implantar um sistema de vias internas (largura mínima de 4m), afim $d$ atender às concessionárias para implantação de redes de água e esgoto.

Atividades realizadas: No projeto de urbanização para o NH Dom João VI, foram ainda consideradas e implantadas algumas praças resultantes do desenho do reparcelamento do solo.

Observações: Projeto de urbanização (reparcelamento) e intervenção das áreas e redes públicas. Cedência de Concessão de Direito Real de Uso para as famílias.

Após a intervenção, foram cedidos 429 unidades habitacionais na área através da Concessão de Direito Real de Uso. 


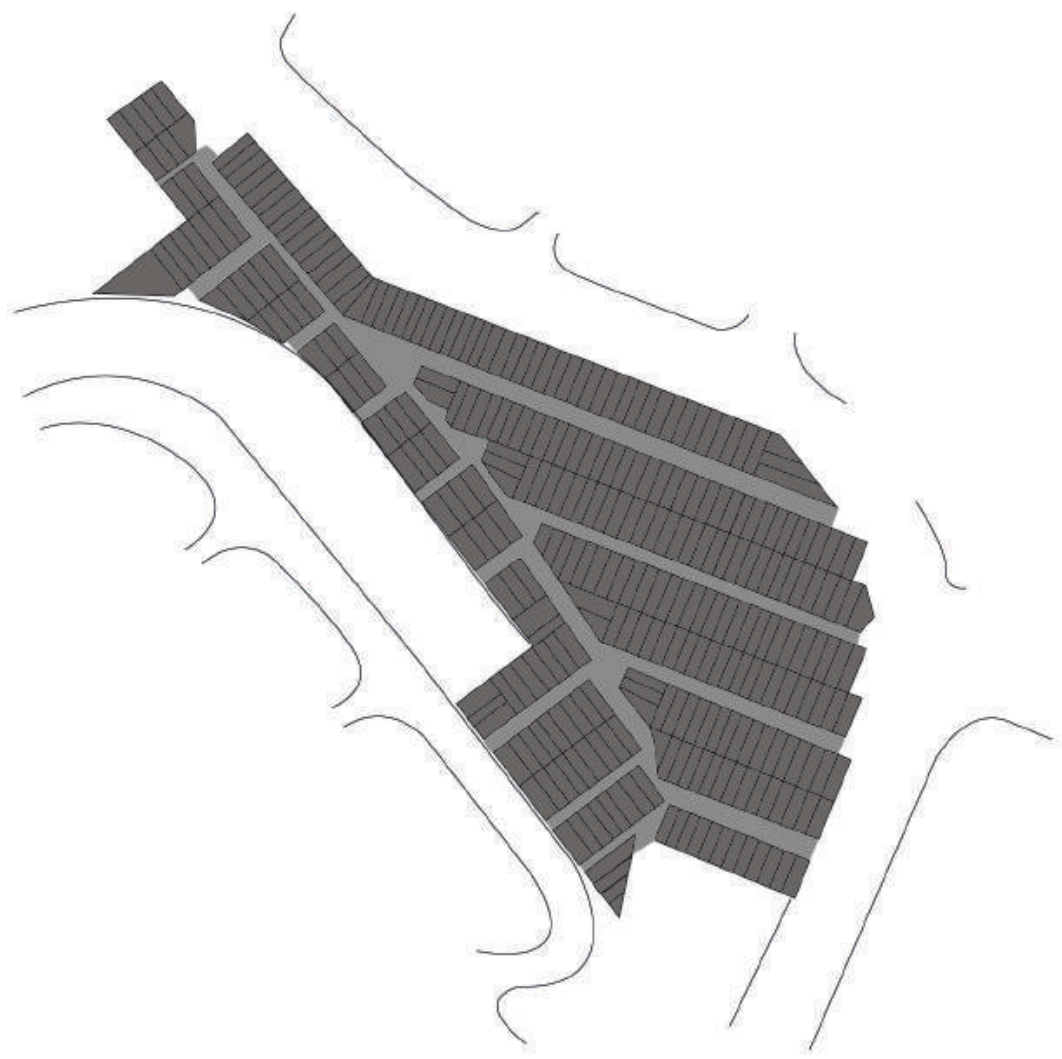

(1)

Legenda

Unidades Habitacionais

Circulaçāo de Pedestres

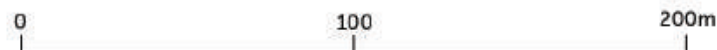

\section{Síntese de Projeto Final Dom João VI}

Desenho realizado sobre desenho da área. O caso é aqui apresentado como ilustrativo da intervenção do Programa de Urbanização de Favelas de Diadema. Note-se a divisão regular da área em lotes equivalentes. Nas áreas remanescentes como nos limites de quadra, eram instaladas praças com equipamentos de bancos, mesas ou brinquedos. As primeiras intervenções eram, normalmente realizadas, a partir do reparacelamento total do solo, definindo vias e lotes regulares que permitissem o acesso e a instalação de infraestrutura.

Elaboração: Beatriz Nobumoto sob coordenação da autora

Fonte base: DENALDI, 2003

(página anterior: Destaque de favela Dom João VI, Diadema, sobre fotografia aérea atual, Google Earth, 2016. Elaboração: Bárbara Muhle sob coordenação da autora) 

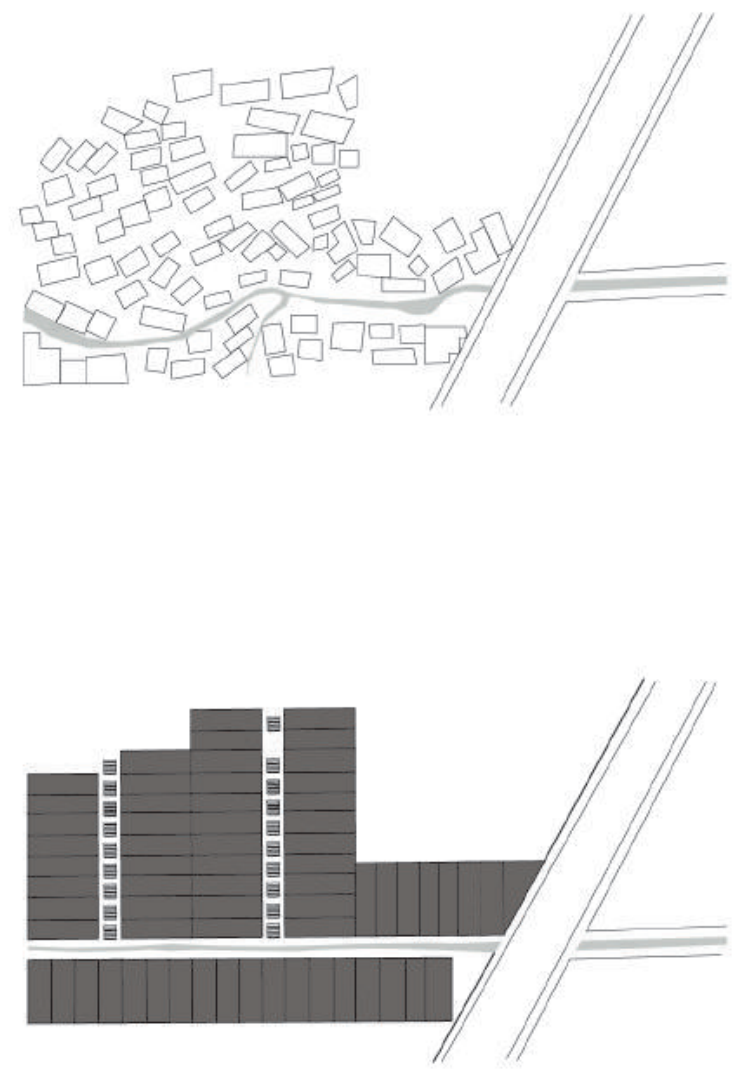

\section{Exemplo de Levantamento e Projeto de Intervenção de área em Diadema}

Desenho realizado sobre desenho. Este exemplo de levantamento e desenho de intervenção (sem identificação, nem escala) representa o modelo de intervenção do Programa. No caso, verifica-se a existência de um córrego que foi retificado e canalizado com a intervenção. Verificamos ainda a implementação de escadas, elementos urbanísticos também disponibilizados, entre outros, pela Prefeitura. 


\section{4-1995 VILA POPULAR, USINA CTAH, DIADEMA - RMSP}

Na última gestão petista da época, e depois de um período de acúmulo de conhecimento sobre intervenções em áreas precárias e informais, foi possível a subcontratação de projetistas para a concretização de projetos para alguns dos assentamentos do município. Uma das áreas foi a Vila Popular para a qual foi contratada a assessoria técnica Usina CTAH. (NAKAMURA, 20I5, informação verbal $\left.^{16}\right)$

Nesta experiência, a assessoria recorreu a um diagnóstico realizado casa a casa, onde foram identificadas e priorizadas o grau de precariedade habitacional sobre o qual ia ser definido as diretrizes projetuais. Considerando que a edificação com menor grau de precariedade tinha maior potencial de consolidação e o mais precário seria mais passível de remanejamento. A obra seria iniciada após um projeto básico previamente definido. A Usina foi contratada também para a etapa de desenvolvimento de obra. (GERMANO, 2015, informação verbal ${ }^{17}$ )

Mesmo com um projeto pensado para tentar prever os problemas que poderiam acontecer, os técnicos da Usina, acompanharam a implementação da obra, e levavam para o escritório, para resolução e readequação, os problemas encontrados no processo. Dado o conhecimento dos técnicos projetistas, que ultrapassava o físico e conheciam a população moradora, e a sua sensibilidade reconhecendo a complexidade destes territórios de intervenção, nem sempre o que estava definido em projeto básico era implementado, muitas vezes modificado e adaptado pela própria equipe projetista. No caso, algumas características sociais definiram a readequação do desenho e implementação da obra, mesmo que as características físicas indicavam outras soluções. (GERMANO, 20 I 5 , informação verbal $\left.^{18}\right)$
Esta experiência constata a importância do reconhecimento de todas as condicionantes e variáveis nestes territórios e dos projetistas que as consideram. Mas também a potencialidade da presença em campo dos projetistas no momento de implantação da obra e a abertura de uma gestão pública para essa possibilidade. Se este conjunto de experiências foi determinante pela quebra de padrões definidos até então na relação entre poder público e a favela, uma atuação da maior escala possível dentro de um cenário de limitação de recursos técnicos e orçamentários, foi da mesma forma originário de outros problemas que ainda temos que enfrentar nos dias de hoje. (NAKAMURA, 20 I 5 , informação verbal ${ }^{19}$ )

As intervenções eram feitas com pouco embasamento técnico e perspectiva global de planejamento, assim como com grande limitação de recursos. Hoje em Diadema, mantém-se uma morfologia de alta densidade construtiva, com poucos espaço públicos e com muitos problemas ambientais complexos, como a questão da permeabilidade e contaminação do solo, a separação de águas e a dificuldade de intervenção e manutenção nos espaços mínimos estabelecidos.

Se na época as propostas técnicas pareciam as ideais, elas acabaram por consolidar precariedades habitacionais e urbanas, e os parâmetros definidos, por mais que se tornaram referência mínima de intervenções, foram muitas vezes replicados sem questionamento e adaptação a outros contextos.

Mesmo assim, as 3 gestões petistas de que falamos, foram responsáveis pela disseminação de conhecimento da RMSP e pela formação de técnicos que vemos atuar até aos dias de hoje em Urbanização de Favelas. ${ }^{20}$

\author{
16. Entrevista realizada \\ em I4/I2/20I5, São \\ Paulo. \\ 17. Entrevista realizada \\ em 27/I I/2015, São \\ Paulo. \\ I8. Idem \\ 19. Entrevista realizada \\ em I 4/I2/2015, São \\ Paulo. \\ 20. Ver nota 49.
}




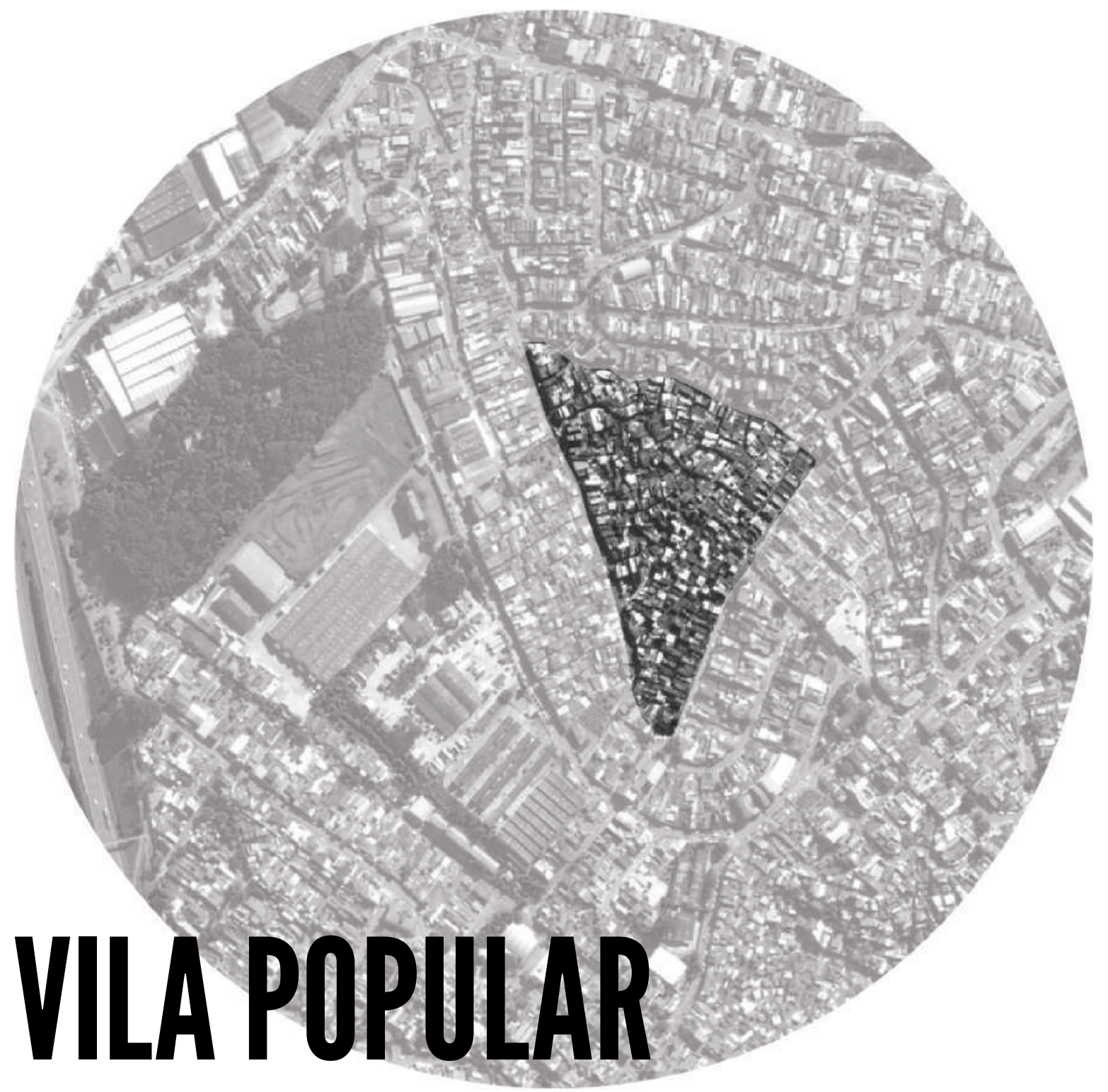

Localização: Diadema - SP

Data: 1994 - 1995: projeto

População: 1064 famílias

Área: $70000 \mathrm{~m} 2$

Projetista: Usina CTAH

Agente Organizador: Prefeitura Municipal de Diadema Agente Financiador: Prefeitura Municipal de Diadema

Escopo: Projetos de urbanismo e infraestrutura. Projeto de arquitetura para Centro Comunitário.

Breve descrição: O projeto proposto pela Usina envolvia a reconfiguração do sistema viário existente, a criação de novas vias, acessos para pedestres e escadarias, o reparcelamento do solo no miolo da favela e a criação de uma praça para a implantação de um Centro Comunitário.

Atividades realizadas: Assessoria na discussão e elaboração dos projetos. Levantamento, diagnóstico, projeto.

Observações: A iniciativa de contratação da Usina é da última gestão progressista do primeiro período PT em Diadema. Inicia um modelo de subcontratação para desenvolvimento de projetos de urbanização de favelas. 


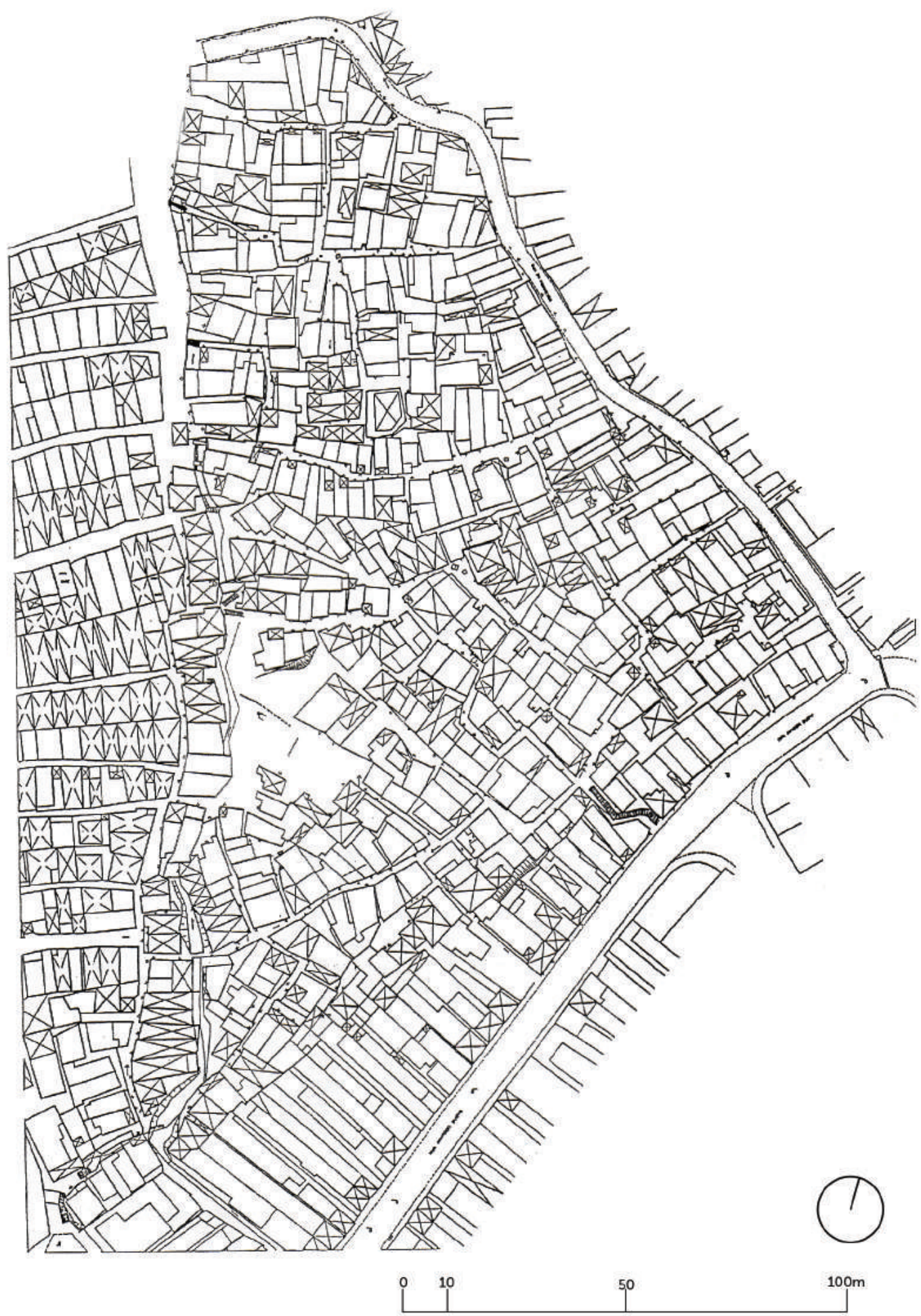

\section{Levantamento da Vila Popular (Usina CTAH)}

A imagem demonstra a irregularidade e densidade do assentamento.

Fonte: cedida por Usina CTAH

(página anterior: Destaque de favela Vila Popular, Diadema, sobre fotografia aérea atual, Google Earth, 2016. Elaboração: Bárbara Muhle sob coordenação da autora) 


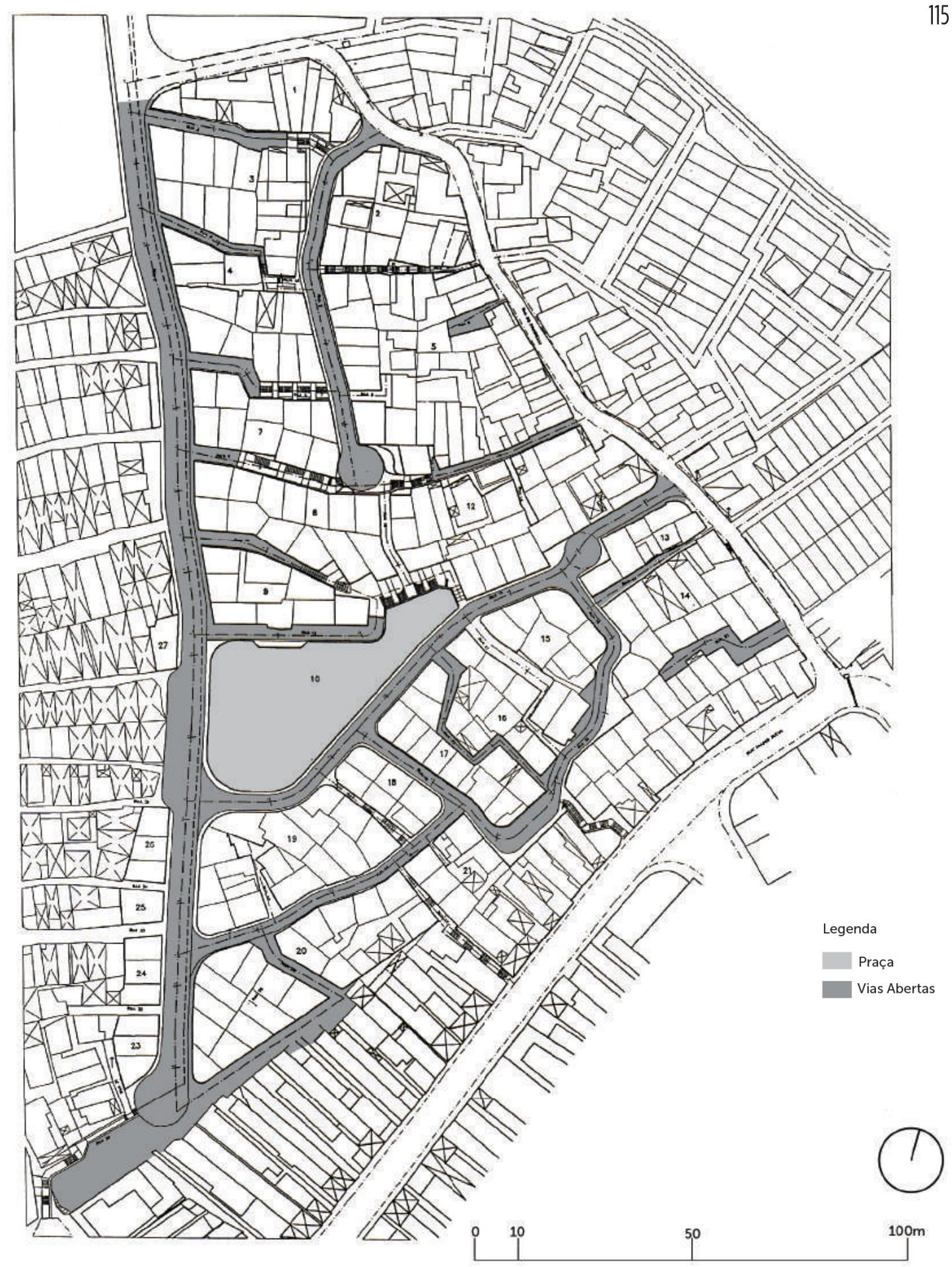

\section{Síntese de Projeto de Intervenção da Vila Popular}

No desenho identificamos uma forma de intervenção que se diferencia da fase anterior. Procura-se uma intervenção a partir do território estabelecido, removendo apenas as edificações necessárias para abertura de vias que permitam o acesso a todas as moradias, ou implementação de equipamentos. $\bigcirc$ centro da favela foi liberado para uma praça, por se tratar do fundo de um vale, área propícia para alagamento. Depois da intervenção, estava prevista a instalação de um centro comunitário.

Elaboração: Bárbara Muhle sob coordenação da autora Fonte base: cedida por Usina CTAH 
ANOS $90 / 2000$

AUMENTO DOS RECURSOS

PÚBLICOSEOS EMPRÉSTIMOS

INTERNACIONAIS.

URBANIZAÇÃO INTEGRADA

As formas ainda pouco desenvolvidas de intervenção dos anos 80 foram progressivamente ganhando escala e complexidade. No final dos anos 90 e anos 2000 estava disseminada a forma de contratação prévia de projeto para urbanização de favelas até para melhor definição e mensuração da obra. E os projetos já previam a integração de diferentes disciplinas.

A economia e finanças públicas começaram a se estabilizar e a progredir. Os municípios ganharam autonomia e protagonismo de atuação e os programas de urbanização passaram a aparecer como centrais em algumas políticas habitacionais municipais. Tudo isso foi fortalecido com mais recursos que chegaram através de empréstimos internacionais.

Na década de 1990 observamos duas tendências: o crescimento da intervenção municipal, com a institucionalização de programas de urbanização como parte integrante da política municipal de habitação, e o aprimoramento das políticas de urbanização, com elevação do patamar técnico de intervenção. (DENALDI, 2003, p.106)

No início da década, a gestão municipal de São Paulo (Luiza Erundina, I 989-1 992) já se tinha destacado num amplo programa de intervenção em favelas e no apoio a movimentos de moradia e produção autoges- tionária de HIS, que inclusive incentivou a criação de inúmeras assessorias técnicas na cidade.

Os recursos vindos da União Europeia - UE, do Banco Mundial, do Banco Interamericano de Desenvolvimento - BID e Banco Internacional de Reconstrução e Desenvolvimento - BIRD possibilitaram a implementação de programas de urbanização de grande escala. Entre eles o Favela -Bairro no Rio de Janeiro, programa Guarapiranga em São Paulo e o Santo André Mais Igual. Por se tratarem de empréstimos, implicavam, para além do pagamento da dívida criada, a submissão às regras colocadas pelos organismos financiadores.

Com eles e simultaneamente à descentralização da ação do estado e uma ação fortalecida dos municípios, observamos a entrada de influencias neoliberais aplicadas às políticas econômicas e sociais.

De fato, a ótica da descentralização é fortalecida na década de 1990, quando as políticas neoliberais influenciam fortemente o desenho das políticas governamentais. A descentralização não é fortalecida como meio de democratizar ou aumentar a eficácia das políticas públicas, mas de aliviar a situação fiscal e financeira da União. (DENALDI, 2003, p.105)

\author{
21. Segundo Tângari \\ (20I6, informação \\ verbal em entrevista \\ 23/I I/2016, Rio de \\ Janeiro) estes programas \\ estabelecem no Rio de \\ Janeiro duas "escolas" \\ distintas de atuação. \\ Aqueles que trabalham \\ na cidade formal \\ (Rio-Cidade) e os que \\ trabalham em favelas \\ (Favela-Bairro). Tal \\ como o Favela-Bairro, o \\ Rio-Cidade promovia a \\ intervenção numa área \\ urbana-circunscrita \\ a um bairro - com \\ intervenções no espaço \\ público, serviçose \\ infraestrutura urbana. \\ Paralelamente, o Bair- \\ rinho seria a mesma \\ forma de intervenção do \\ Favela-Bairro, mas dire- \\ cionado para pequenas \\ comunidades.
}




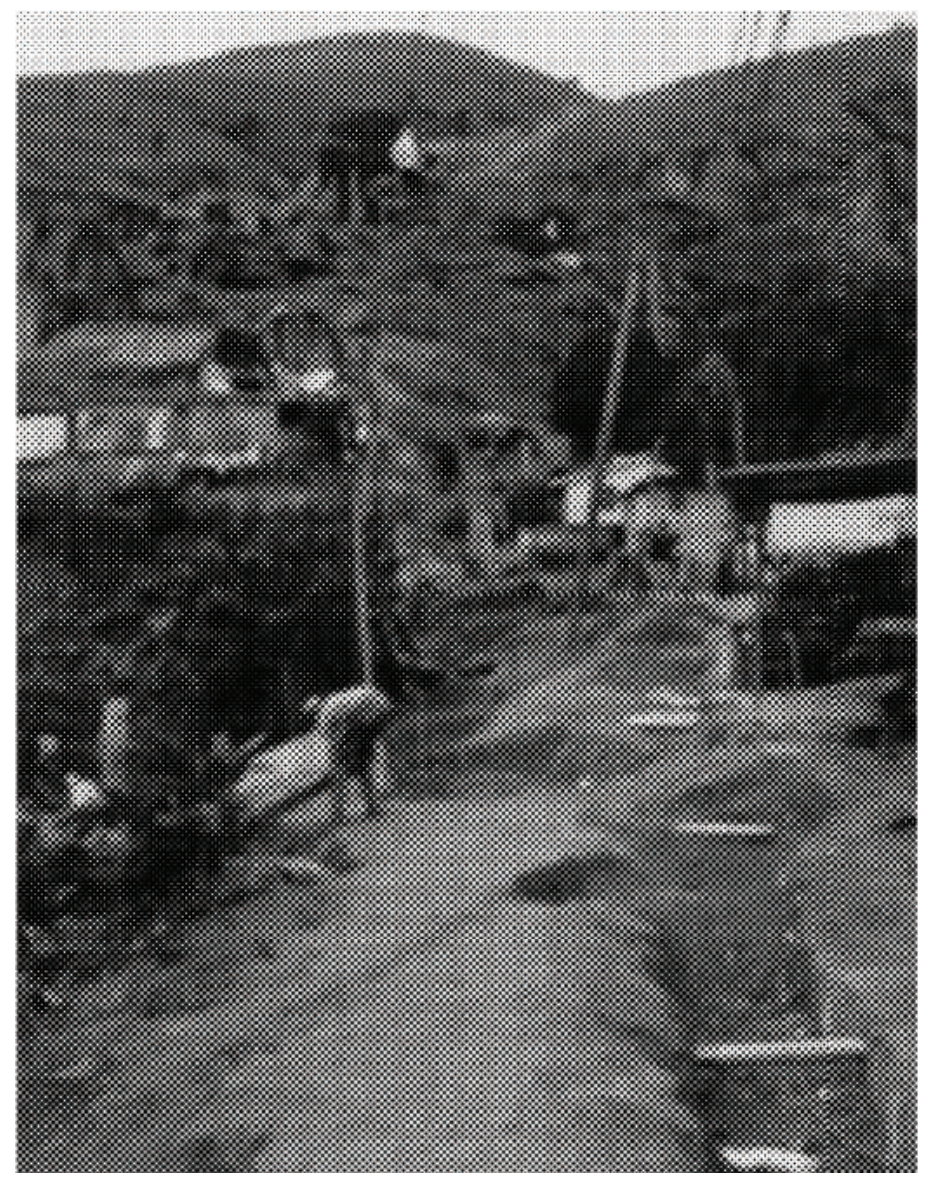

22. No seu relato, Manoel suspeita que os técnicos da Prefeitura tenham encaminhado a sua ação para a Serrinha pela facilidade de diálogo do arquiteto com a comunidade, pois sabiam do seu relacionamento pessoal com alguns dos chefes do tráfico na época, derivado de um dos projetos sociais que $\mathrm{Ma}$ noel tinha desenvolvido com jovens oriundos de comunidades. (RIBEIRO, 20I5, informação verbal em entrevista 20/II/20I5, Rio de Janeiro).

\section{6-2001 SERRINHA, MANOEL RIBEIRO E EQUIPE, RIO DE JANEIRO}

Com apoio dos recursos internacionais, a gestão municipal do Rio de Janeiro, lança em I 993 o concurso público para o Programa Favela-Bairro. O programa terá posteriormente outras edições e é contemporâneo de outros programas municipais de intervenção urbana o Rio-Cidade e o Bairrinho ${ }^{21}$.

$\mathrm{Na}$ sua primeira edição, o Favela -Bairro propôs a intervenção em assentamentos precários irregulares da cidade, contratando escritórios de arquitetura designados para cada assentamento. Para o concurso, os assentamentos já estavam previamente definidos e os escritórios se candidataram para os assentamentos que lhes interessavam. Aos escritórios de arquitetura cabia o desenho dos projetos fig. 4 Serrinha (RJ) antes da inter-

venção do Favela-Bairro.

Fonte: DENALDI, 2016 - apresen-

tação da I Oficina: Favelas.

básicos de intervenção espacial, assim como a compatibilização com as restantes disciplinas.

Na primeira etapa do Favela-Bairro destacaram-se os Pousos, espaços de representação do poder público dentro da favela, que possibilitaram a relação e diálogo entre a comunidade e o programa, facilitando a sua implementação e pós-ocupação dos espaços construídos.

A Serrinha foi um dos primeiros assentamentos a receber o programa. $\mathrm{O}$ projeto foi desenvolvido pelo arq. Manoel Ribeiro, referência já na intervenção em assentamentos precários no Rio de Janeiro e no desenvolvimento de projetos sociais junto a comunidades desfavorecidas. ${ }^{22}$

$\mathrm{Na}$ sua proposta prévia, que compreendia um diagnóstico parcial, Manoel tomou como partido o reconhecimento social do território e as soluções técnicas já utilizadas pelos seus moradores. Isso implicou a compreensão e conhecimento sobre a formação da favela e o estabelecimento das diferentes comunidades ali presentes, das dinâmicas sociais, que acabaram por influenciar projeto para além apenas das características físicas. A sua proposta técnica tratava-se da apresentação de tipologias de soluções baseadas na própria comunidade, a implementar conforme a necessidade. Isso implicava uma intervenção física por administração direta e a presença constante do projetis- 
fig. 5 Serrinha (RJ) depois da intervenção do Favela-Bairro. Fonte: DENALDI, 2016 - apresentação da I Oficina: Favelas.

ta em campo. A proposta foi aceite pela prefeitura e Manoel Ribeiro frequentou durante 6 anos a Serrinha para a sua implementação. $\mathrm{O}$ arquiteto define esta como uma intervenção de "alta-costura" onde a proposta é totalmente adaptada ao território e usuários. Manoel olhou para a Serrinha pelos seus potenciais e não apenas pelo viés das problemáticas e na sua proposta procurou fortalece-los. (RIBEIRO, 20 I 5, informação verbal ${ }^{23}$ )

Nas suas principais críticas sobre o processo estão o questionamento sobre o significado da palavra diagnóstico e como ela é utilizada em processos de urbanização de favela. Para o arquiteto,

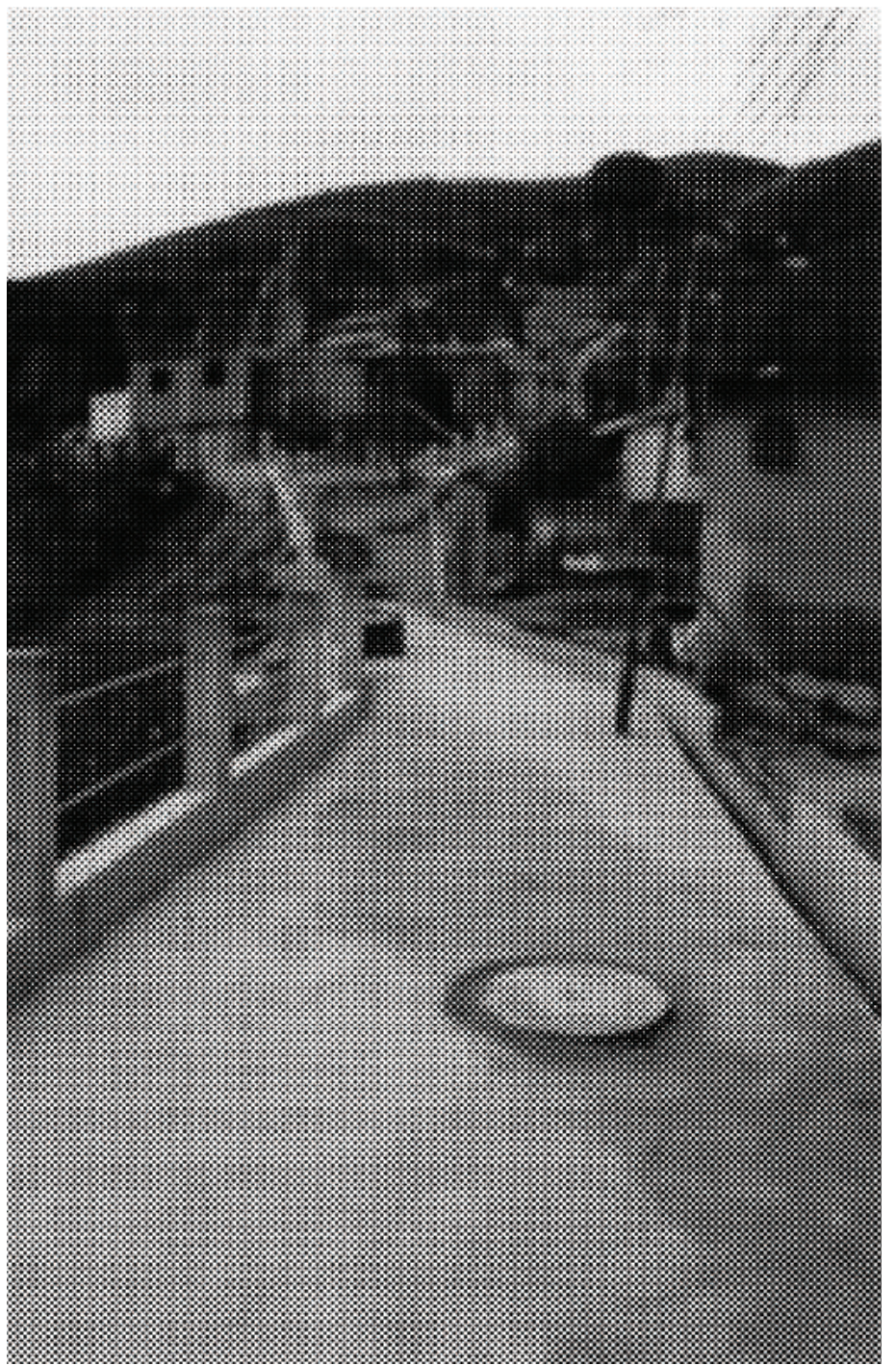

diagnóstico é um conceito que reflete um

23. Entrevista realizada olhar para doenças e por isso um olhar preconceituoso sobre as comunidades. Ao mesmo tempo Ribeiro (20 I 5 ) reforça a importância desta etapa no processo de urbanização de favelas, ela é determinanem 20/II/2015, Rio de Janeiro.

24. Entrevista realizada

em 20/II/2015, Rio de Janeiro. te para o conhecimento do lugar e para a definição da estratégia de intervenção e deve ser realizada cuidadosamente, no tempo necessário e pelo próprio projetista, só com um diagnóstico (ou leitura) extensivo é possível sustentar projeto. (RIBEIRO, 20 I 5, informação verbal ${ }^{24}$ ) 


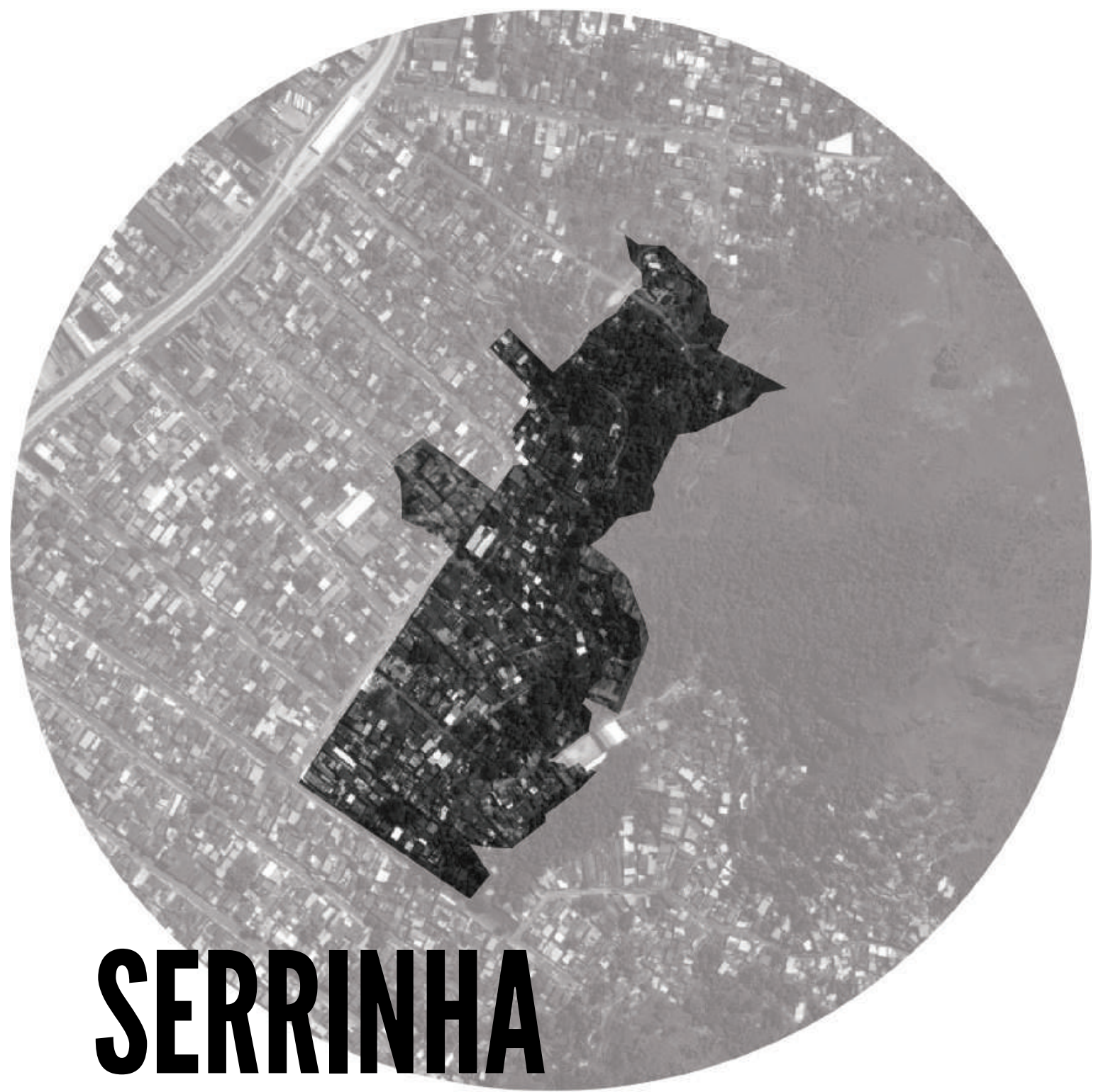

Localização: Rio de Janeiro

Data: 1996 - 2001

População: 604 domicílios

Projetista: Manoel Ribeiro e equipe

Agente Organizador: Programa Favela-Bairro, Secretaria Municipal de Habitação - SMH, Prefeitura Municipal do Agente Financiador: Rio de Janeiro PMRJ

SMH PMRJ, BID - PROAP I (Programa de Urbanização de Assentamentos Populares - fase I)

Escopo: Realização de levantamentos, diagnóstico, estudos preliminares, básicos e acompanhamento de obra.

Breve descrição: Primeira fase do Programa Favela-Bairro.

Atividades realizadas: Levantamentos, diagnóstico, estudos preliminares, básicos e implementação de obra.

Valor: R\$ 8.237.222,60

Observações: Ribeiro propôs um projeto de intervenção através de "padrões urbanísticos", que iam sendo aplicados conforme as necessidades. A sua concretização em ora só foi possível pela contratação, numa primeira fase, por administração direta o que permitiu a presença constante do arquiteto na favela durante 6 anos, definindo, desenhando e dialogando com trabalhadores e moradores no próprio canteiro onde as decisões eram tomadas. 


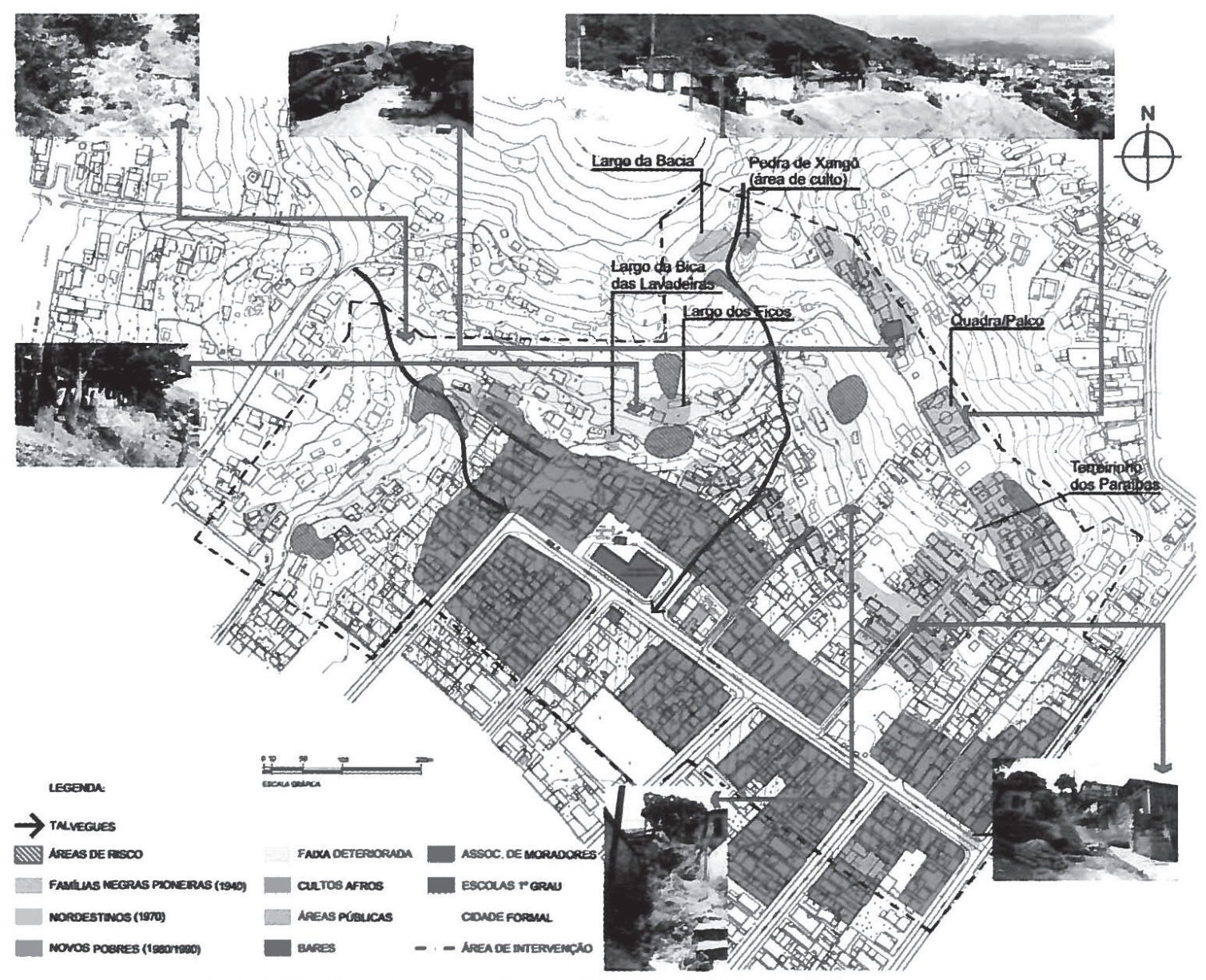

\section{Diagnóstico da Serrinha (RIBEIRO, 2004)}

No diagnóstico, Manoel Ribeiro identificou os pontos de destaque da favela, entre potencialidades de problemas a resolver. As manchas representam as comunidades identificadas pelo arquiteto.

(página anterior: Destaque de favela Serrinha, Rio de Janeiro, sobre fotografia aérea atual, Google Earth, 2016. Elaboração: Bárbara Muhle sob coordenação da autora) 


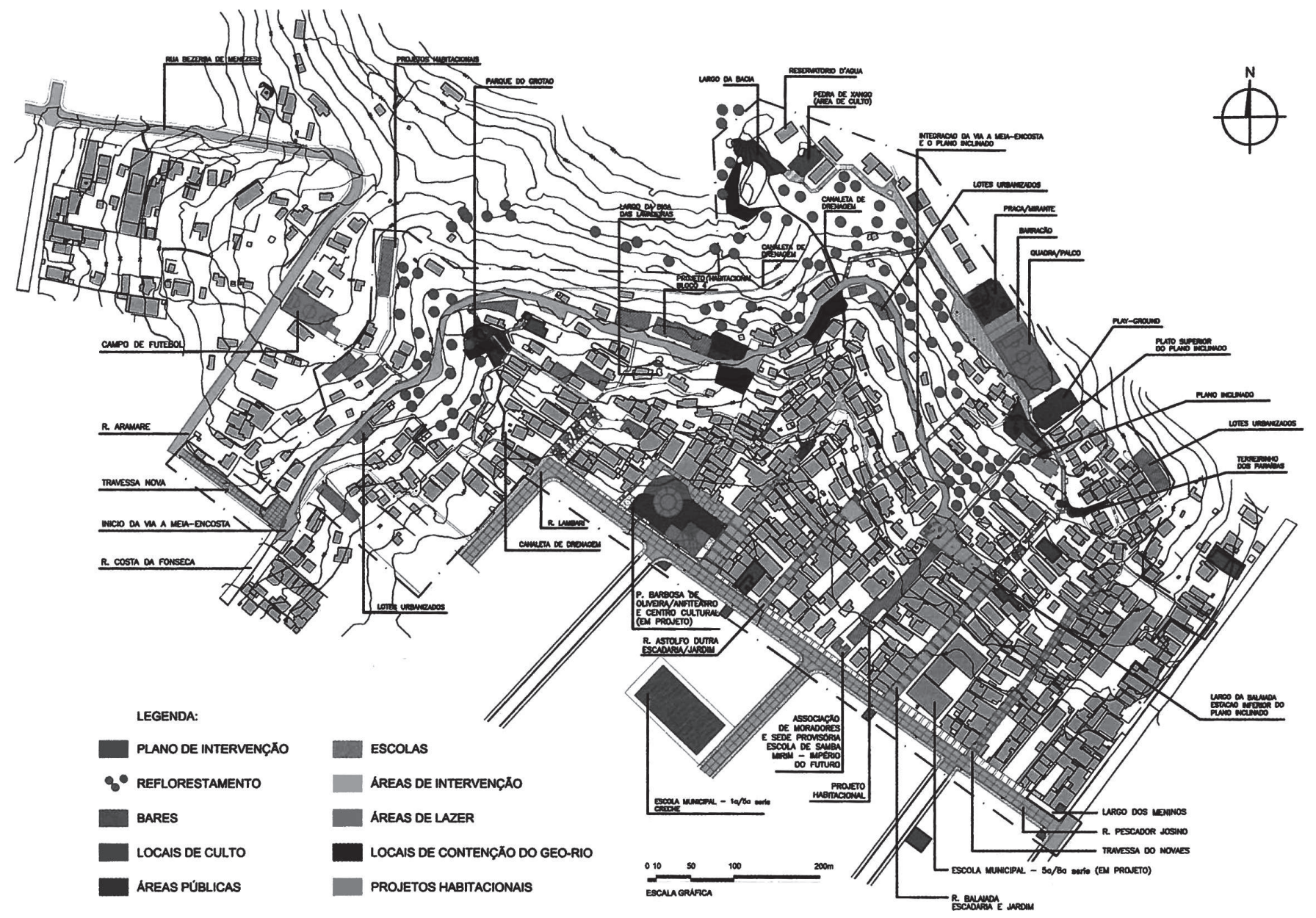

\section{Plano de Intervenção da Serrinha}

O desenho representa as ideias urbanisticas gerais de intervenção. Os detalhes e soluções construtivas eram pensados e desenhados em obra adequando-se a cada lugar. Neste plano identifica-se, para além das linhas de projeto, elementos existentes na comunidade, revelando a importância desses para a definição de projeto. Fonte base: RIBEIRO, 2004 


\section{9-2003 CANTAGALO E PAVÃO-PAVÃOZINHO, CONSÓRCIO CO- BRAPE / MAYERHOFFER \& TOLEDO / MPS ASSOCIADOS, RIO DE JANEIRO}

Em 1999 a Prefeitura do Rio de Janeiro lança uma segunda etapa do programa Favela-Bairro para intervenções em outras comunidades, com financiamento via PROAP II (Programa de Urbanização de Assentamentos Populares - fase II) ainda com apoio do BID. Nelas estão incluídas as favelas Cantagalo e Pavão-Pavãozinho, conhecidas favelas contíguas na zona sul da cidade. A gestão municipal seleciona o consórcio Consórcio Cobrape / Mayerhoffer \& Toledo aliado ao escritório MPS Arquitetos como os projetistas.

O projeto foi desenvolvido pela vontade do arquiteto Jonathas Magalhães de trabalhar com assentamentos precários, acabando por convencer a colega Vera Tângari e por fim o arq. Luiz Carlos Toledo a apadrinhar a iniciativa. Toledo participou envolvendo o nome e estrutura da sua empresa e base de trabalho no Rio de Janeiro dentro do seu próprio escritório, mas abstendo-se como projetista, com a condição de chamarem Manoel Ribeiro para participar como consultor, o que foi aceite por todos. (SILVA, 2015 , informação verbal ${ }^{25}$ )

Na segunda fase do Favela-Bairro o programa tinha alterado algumas das suas premissas iniciais. A participação popular e relação comunitária aparentavam não ter tanta importância para a gestão pública e aos arquitetos projetistas não era permitida, ou era menos possibilitada, a circulação livre dentro das comunidades. A iniciativa Pouso tinha também sido abolida. (SILVA, 2015 , informação verbal ${ }^{26}$ e TÂNGARI, 2016 , informação verbal ${ }^{27}$ )

Mesmo nestas condições, e influenciados pela consultoria de Manoel Ribeiro, os projetistas reuniram um equipe, inclusive com moradores da comunidade, e fizeram um levantamento casa a casa reconhecendo pessoalmente as problemáticas e potencialidades locais. A participação de Manoel foi fundamental para a compreensão do dinamismo e estrutura social das duas favelas. Para os arquitetos da equipe o processo participativo se dava no convívio diário e aproximado com a comunidade. Também nesta fase do Favela-Bairro, a participação dos arquitetos limitava-se ao desenho dos projetos básicos e coordenação dos complementares, não estando previsto o acompanhamento em fase de obra, como acontecera na Serrinha. Os arquitetos desenharam exaustivamente e com muitos detalhes os projetos básicos, aproximando-se de desenhos de projeto executivo. Os projetistas foram afastados do processo e da comunidade antes da etapa de obra e sem saberem se os seus desenhos seriam implementados conforme o previsto. Mais tarde, outros técnicos confirmaram que as propostas desenhadas no Favela -Bairro para Cantagalo Pavão-Pavãozinho foram quase todas implementadas com rigor ${ }^{28}$. (SILVA, 2015 , informação verbal ${ }^{29}$ )

As críticas dos projetistas referentes a este processo vão, obviamente, no sentido das dificuldades impostas pelo poder público para a relação com a comunidade, e para os chamados "métodos participativos" que utilizavam, e que, na opinião de Vera, seriam apenas apresentação dos projetos para validação das propostas já definidas (TÂNGARI, 20 I6, informação verbal $\left.^{3 \circ}\right)$. Além disso, o desenvolvimento de projeto foi bastante impactado e prolongado por idas e vindas dos desenhos apresentados. Os técnicos responsáveis acabavam por dificultar a aprovação de projeto por questões questionáveis ou superficiais, como aspetos gráficos de representação e não por questões projetuais. $\mathrm{O}$ "projeto básico com cara de executivo" (SILVA, 2015 , informação verbal ${ }^{31}$ ) acabou por ser também uma exigência dos órgãos aprovadores, que na perspectiva dos projetistas subestimaram o tempo, o processo e os valores de contratação necessários para o desenvolvimento de um projeto de urbanização de favelas. (SILVA, 2015 , informação verbal ${ }^{32}$ )

$$
\begin{aligned}
& \text { 25. Entrevista realizada } \\
& \text { em 26/10/2015, São } \\
& \text { Paulo. } \\
& \text { 26. Idem. } \\
& \text { 27. Entrevista realizada } \\
& \text { em 23/i I/2016, Rio de } \\
& \text { Janeiro. } \\
& \text { 28. Para o desenvolvi- } \\
& \text { mento dos projetos } \\
& \text { para Cantagalo e } \\
& \text { Pavão-Pavãozinho no } \\
& \text { âmbito do PAC e na } \\
& \text { preparação da cidade } \\
& \text { para os eventos esport- } \\
& \text { ivos: Copa do Mundo } \\
& 2014 \text { e Jogos Olímpicos } \\
& \text { 20 I6, foi contratado o } \\
& \text { escritório Arquitraço. } \\
& \text { Na comparação com } \\
& \text { os desenhos realizados } \\
& \text { para o Favela-Bairro } \\
& \text { entre } 1999 \text { e } 2003 \text { as } \\
& \text { arquitetas da Arquit- } \\
& \text { raço puderam confir- } \\
& \text { mar que as propostas } \\
& \text { tinham sido quase todas } \\
& \text { implementadas e de } \\
& \text { forma rigorosa pela em- } \\
& \text { presa contratada para } \\
& \text { construção da obra. } \\
& \text { 29. Entrevista realizada } \\
& \text { em 26/1o/20I 5, São } \\
& \text { Paulo. } \\
& \text { 30. Entrevista realizada } \\
& \text { em 23/i I/2016, Rio de } \\
& \text { Janeiro. } \\
& \text { 31. Entrevista realizada } \\
& \text { em 26/10/2015, São } \\
& \text { Paulo. } \\
& \text { 32. Idem }
\end{aligned}
$$




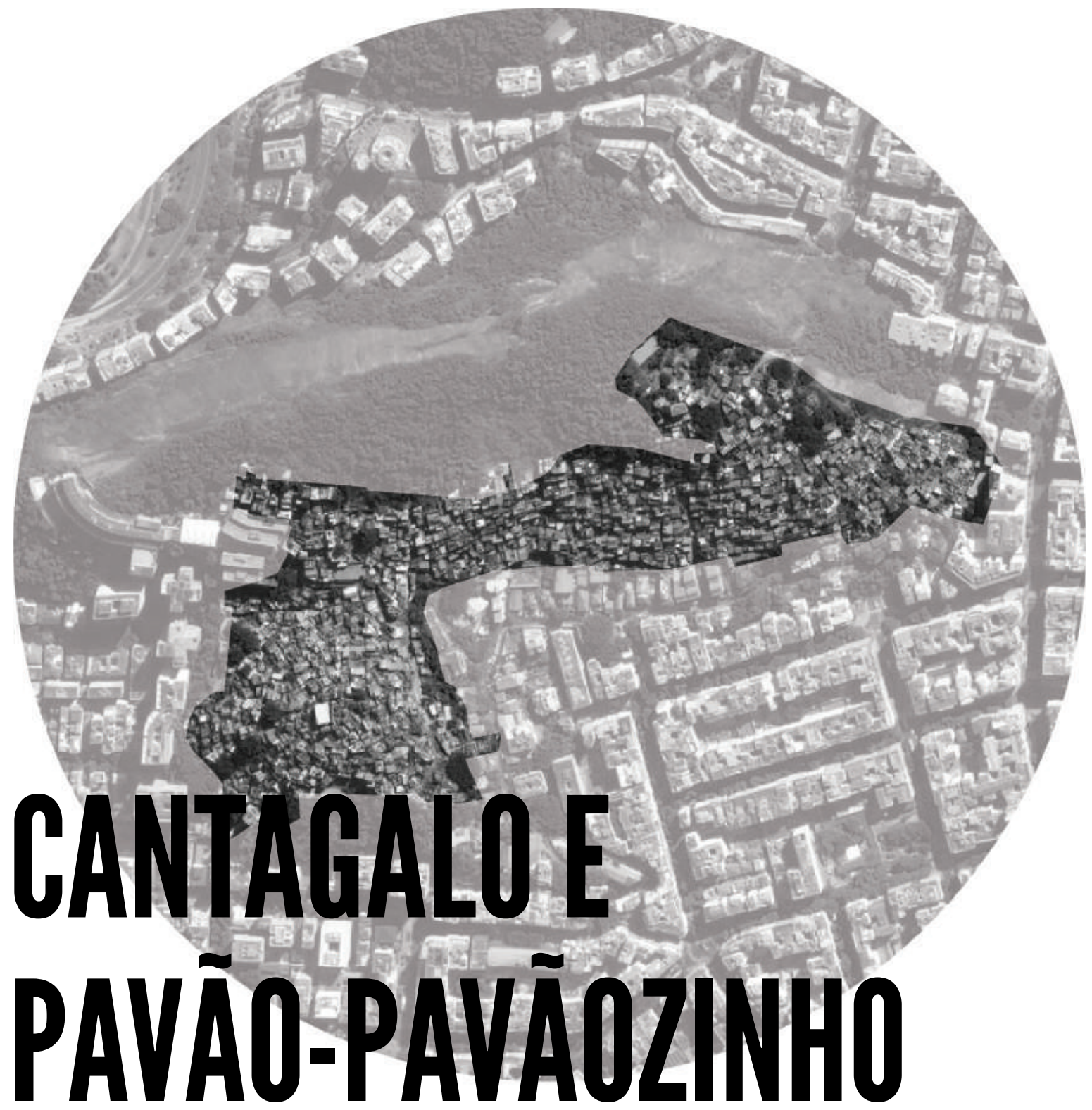

Localização: Rio de Janeiro

Data: 1999-2003

População: Cantagalo: 858 domicílios. Pavão-Pavãozinho: 1850 domicílios.

Área: Cantagalo: $70.080 \mathrm{~m} 2$ Pavão-Pavãozinho: $62.348 \mathrm{~m} 2$

Projetista: Consórcio Cobrape / Mayerhoffer \& Toledo / MPS associados (colaboração de Manoel Ribeiro) Agente Organizador: Programa Favela-Bairro, Secretaria Municipal de Habitação - SMH, Prefeitura Municipal do Rio de Janeiro PMRJ

Agente Financiador: SMH PMRJ, Banco Interamericano de Desenvolvimento - BID - PROAP II (Programa de Urbanização de Assentamentos Populares - fase II)

Escopo: Projetos de Água, Esgoto, Drenagem, Iluminação Pública, Sistema Viário, Paisagismo, Mobiliário Urbano e delimitação de AEIS e os projetos de arquitetura de unidades habitacionais, creche e centro de apoio social

Breve descrição: Segunda fase do Programa Favela-Bairro. Como na primeira fase, a proposta era de intervenção integrada nas favelas, com projetos urbanísticos, complementares e de HIS, mas prevendo o mínimo de remoção possível.

Atividades realizadas: Levantamentos, Diagnóstico e Projetos.

Observações: Nesta fase, o programa dificultava a relação dos projetista com as comunidades dificultando a possibilidade de uma propostas participativa. A obra foi parcialmente implementada - projetos de intervenção em vias e áreas públicas, mas sem a participação da equipe projetista. 


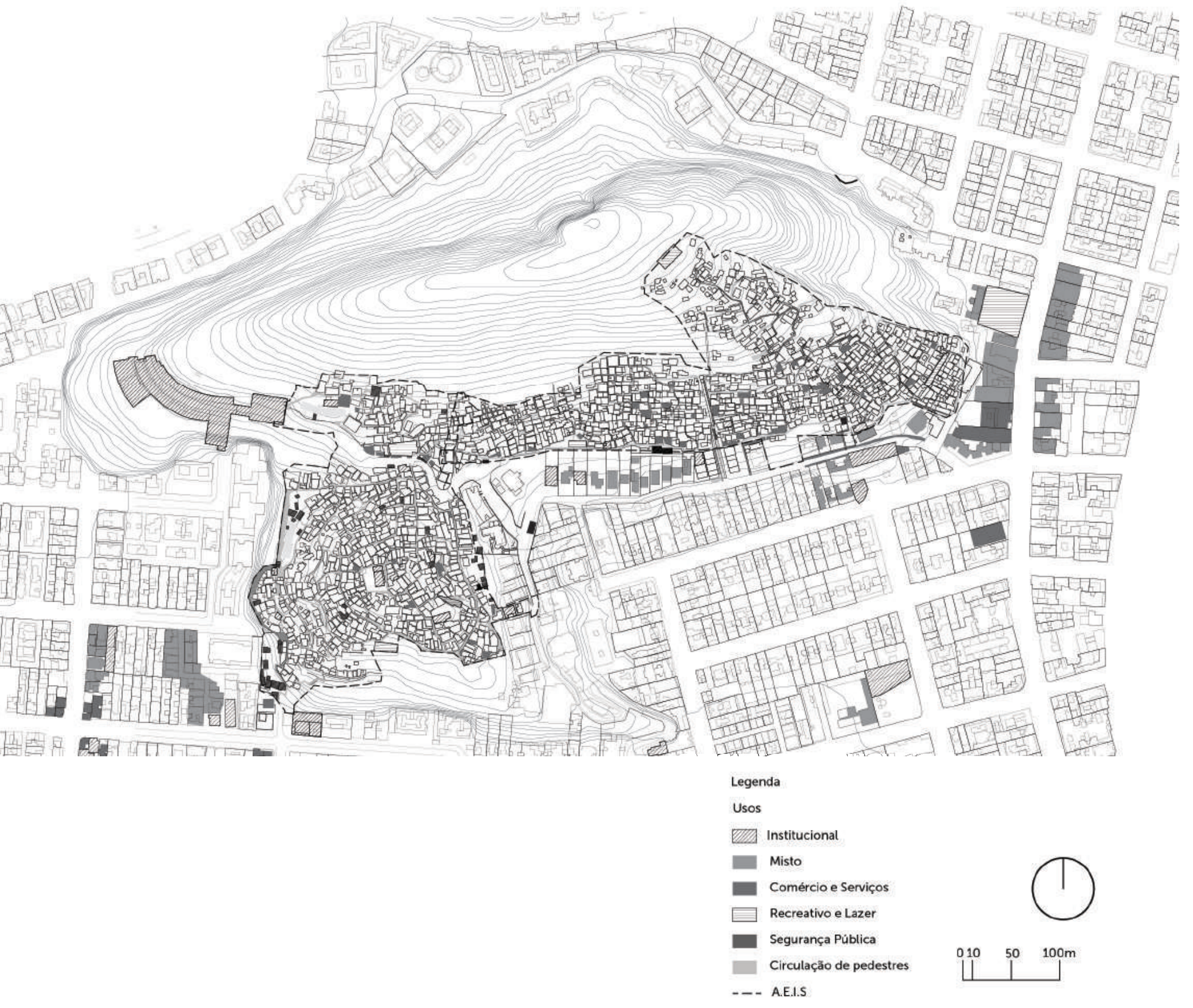

\section{Síntese de Levantamento e Diagnóstico de Cantagalo e Pavão-Pavãozinho}

Desenho elaborado a partir da junção das bases de levantamento de Cantagalo e Pavão-Pavãozinho, realizadas pelos projetistas. $\bigcirc$ desenho demonstra a densidade de ocupação, a relação com a regularidade da Zona Sul do Rio de Janeiro (Copacabana) mas também morfologia íngreme do terreno. Para a intervenção, as favelas Cantagalo (ocupação de forma concêntrica, à esquerda) e Pavão-Pavãozinho (ocupação mais linear, topo central e direita) estavam separadas em contrato, o que implicava a duplicação de todos os produtos a serem entregues.

Elaboração: Bárbara Muhle sob coordenação da autora

Fonte base: cedida por Jonathas Silva

(página anterior: Destaque das favelas Cantagalo e Pavão-Pavãozinho, Rio de Janeiro, sobre fotografia aérea atual, Google Earth, 2016. Elaboração: Bárbara Muhle sob coordenação da autora) 


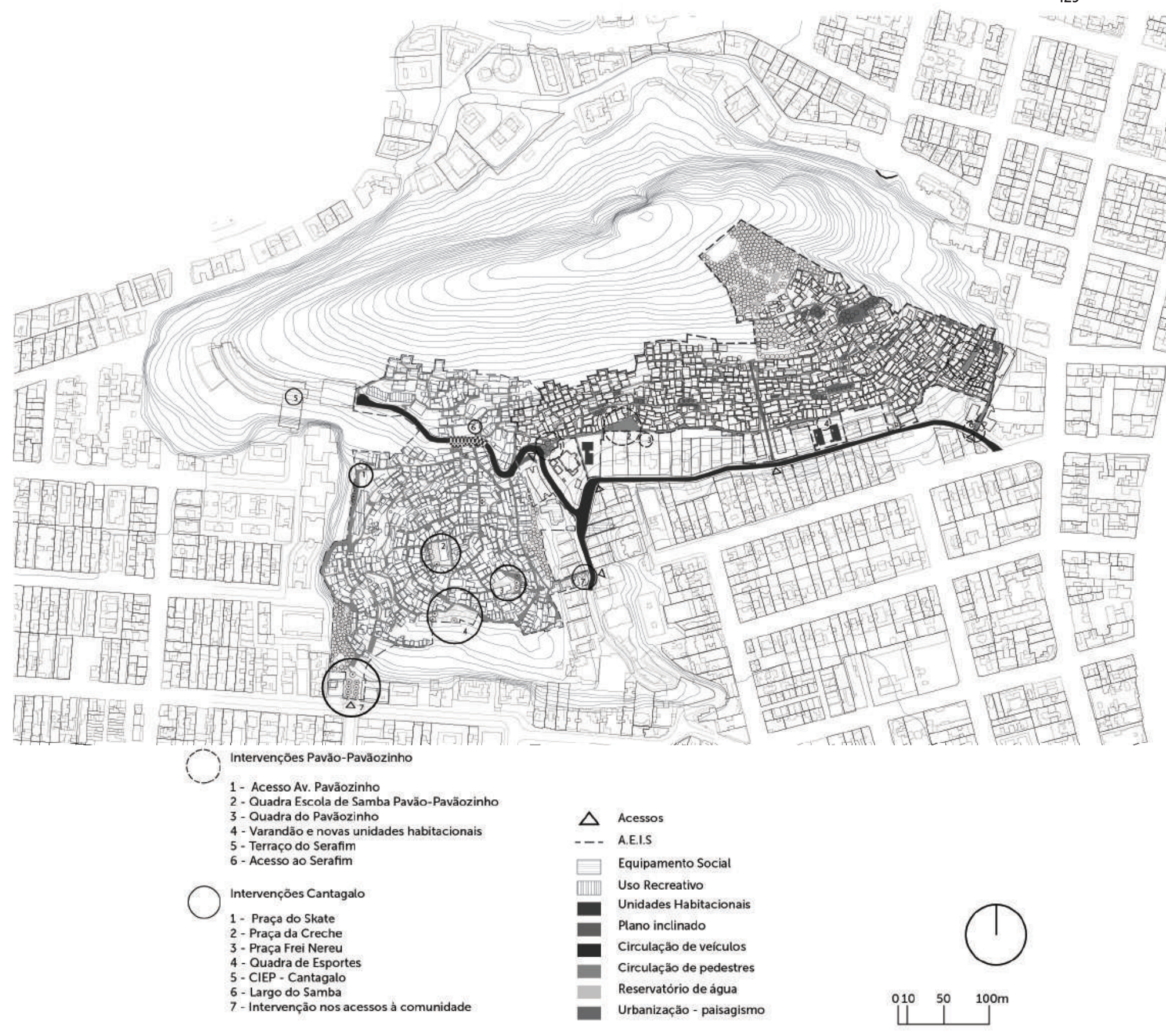

\section{Síntese de Projeto de Intervenção de Cantagalo e Pavão-Pavãozinho}

Desenho elaborado a partir da junção das bases de projeto de Cantagalo e Pavão-Pavãozinho, realizadas pelos projetistas. No desenho são destacadas as propostas de intervenção em Cantagalo e Pavão-Pavãozinho. No projeto identificam-se algumas aberturas de vias, mas poucas remoções, o que era premissa do Programa. O projeto propunha a implantação de edificicios de Habitação de Interesse Social que não chegaram a ser implementados, assim como os restantes edificios de equipamentos

Elaboração: Bárbara Muhle sob coordenação da autora

Fonte base: cedida por Jonathas Silva 


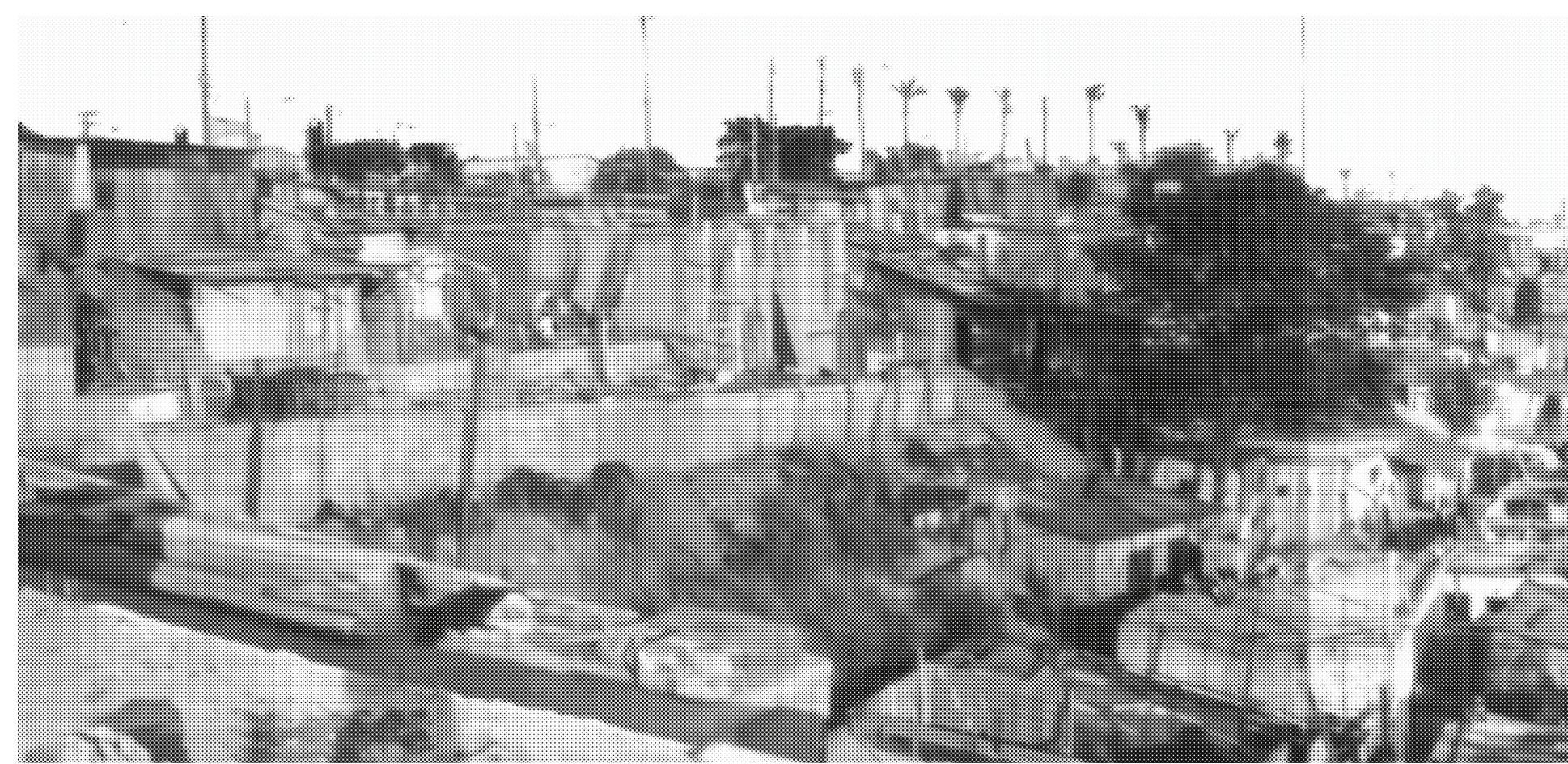

\section{0-2003 TAMARUTACA, PEABIRU TCA, SANTO ANDRÉ - RMSP}

No mesmo período, na RMSP com a dissolução do quadro técnico montado na Prefeitura de Diadema entre os anos 80 e 9o, os profissionais encontraram espaço em diferentes lugares. Alguns tomaram o caminho de profissionais autônomos outros foram integrados em programas públicos com as mesmas ambições progressistas e de intervenção social. A Prefeitura de Santo André também na RMSP destacouse no final dos anos 90 e começo dos anos 2000 com o PIIS - Programa Integrado de Inclusão Social, com apoio da Comissão Europeia, e mais tarde, na readequação do programa o Santo André Mais Igual. Estes projetos destacam-se como referência nacional e internacional por seu carácter integrador de linhas de atuação e políticas públicas na melhoria de qualidade de vida das populações afetadas.
Buscando transpor a abordagem setorial e combater a exclusão social, o governo municipal lançou em 1997 o PIIS (Programa Integrado de Inclusão Social), dentro do qual se insere o Programa de Urbanização Integrada de favelas. $O$ PIIS destina-se a atender as famílias moradoras de núcleos de favela em processo de urbanização com diversos programas setoriais (habitação, educação, saúde, garantia de renda, desenvolvimento econômico, entre outros), articulados institucionalmente e concentrados espacialmente. $\bigcirc$ slogan 'Tudo junto, ao mesmo tempo e no mesmo lugar' resume a expressão desta idéia (SANTO ANDRÉ, apud DENALDI, 2003, p.152). 
fig. 6 Vista geral Tamarutaca,

Santo André.

Fonte: cedida por Peabiru
33. Entrevista realizada em I 7/I I/20 I 5, São Paulo.
A intervenção do programa de urbanização integrada Santo André Mais Igual em Santo André focou em quatro assentamentos, um deles, Tamarutaca, foi desenvolvido, em seu período final, pela Peabiru TCA, outra assessoria técnica de São Paulo.

A Peabiru foi chamada em 2000 numa fase em que parte do processo já tinha sido implementado. As diretrizes gerais de projeto já estavam definidas e a Peabiru foi contratada para a continuidade da sua implementação, no entanto ainda muita coisa estaria em aberto. Os técnicos da Peabiru acompanhavam a obra e resolviam no local os problemas que iam surgindo conforme as necessidades dos moradores e as limitações do terreno. A assessoria foi contratada por administração direta, o que permitia maior flexibilidade de atuação e implementação. Uma das funções da Peabiru era a assessoria às famílias para a construção ou recons- trução das suas habitações. A assessoria desenvolveu alguns modelos que melhor se adaptavam aos lotes previamente definidos, garantindo condições e qualidade mínimas de habitabilidade, que consideravam entre outros aspetos, insolação, ventilação, dimensões mínimas e opções de evolução da edificação. Apesar da disponibilidade de assessoria dos técnicos presentes no assentamento e próximos da comunidade, a construção das habitações era da total responsabilidade dos seus moradores.

(SANTO AMORE e MARQUES, 20 I 5 , informação verbal ${ }^{33}$ )

Entre as possibilidades dadas nesta forma de contratação e acompanhamento dos técnicos junto da comunidade, os técnicos da Peabiru questionam a pouco exploração da densificação do assentamento, sendo que isso seria possível. Outro questionamento foi ao desenho dos lotes "tipo gaveta" 

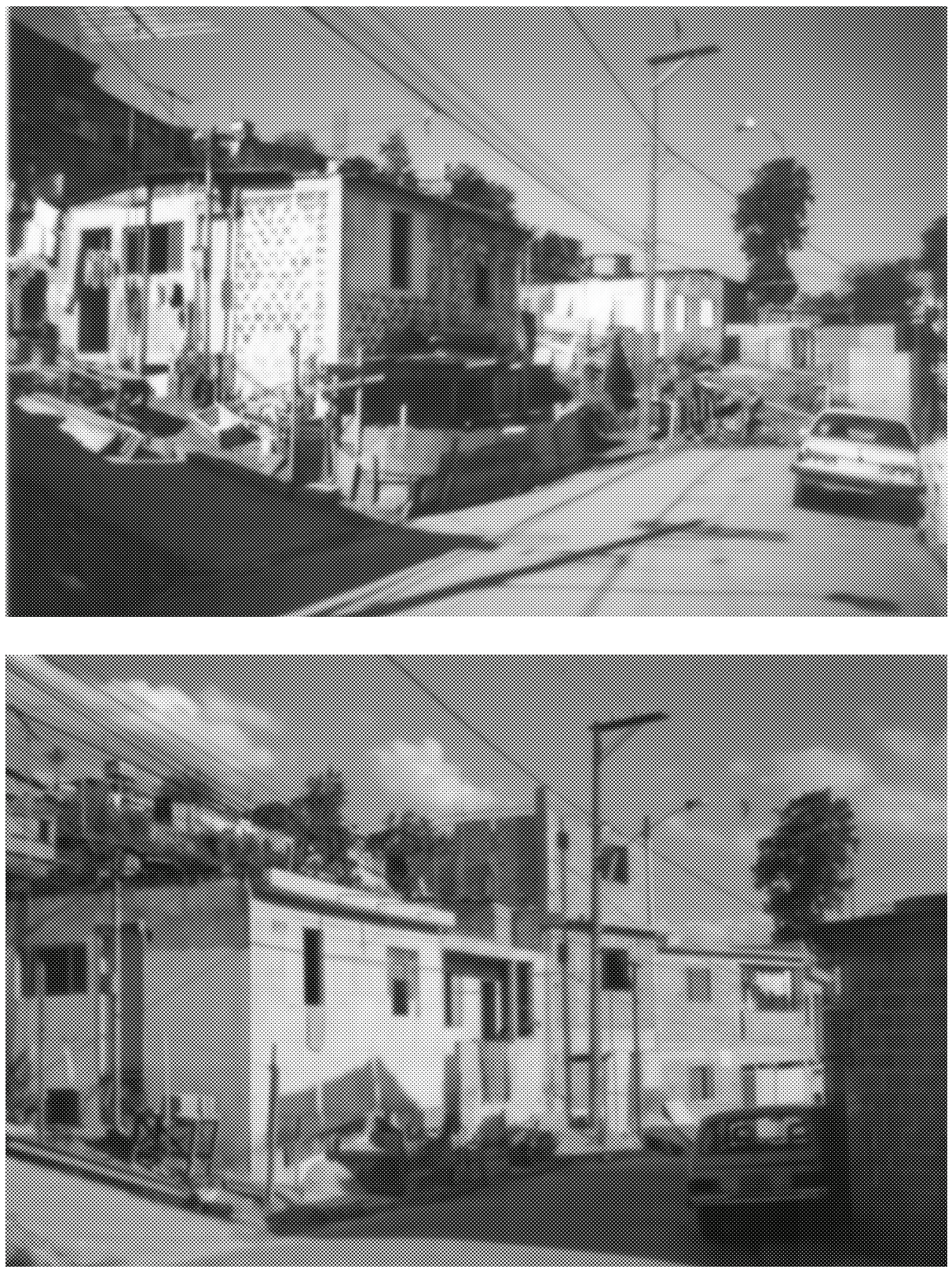

fig. 7 e 8 Tamarutaca, Santo

André, fotografia de casa, antes e depois da intervenção.

Fonte: cedida por Peabiru TCA

(SANTO AMORE e MARQUES, 20 I 5 , informação verbal ${ }^{34}$ ), definidos previamente pela prefeitura, lotes muito compridos e estreitos, que limitavam as opções de ocupação dos terrenos. Caio Santo Amore lembra também uma relativa ausência do poder público no caso da Tamarutaca, que a partir do momento de terceirização do trabalho para a Peabiru, passou a ter menor presença em campo. Por fim, o envolvimento da Peabiru terminou quando terminou o recurso financeiro, mesmo que o trabalho ainda não estivesse concluído. Os técnicos envolvidos criticam ainda o olhar parcial sobre o território, numa ação "tipo bordado" (SANTO AMORE e MARQUES, 20 I 5 , informação verbal ${ }^{35}$ ), que observava e intervia em assentamentos de forma segmentada, sem um planejamento macro para o munícipio e território contíguo.

\section{Idem}

35. Idem 


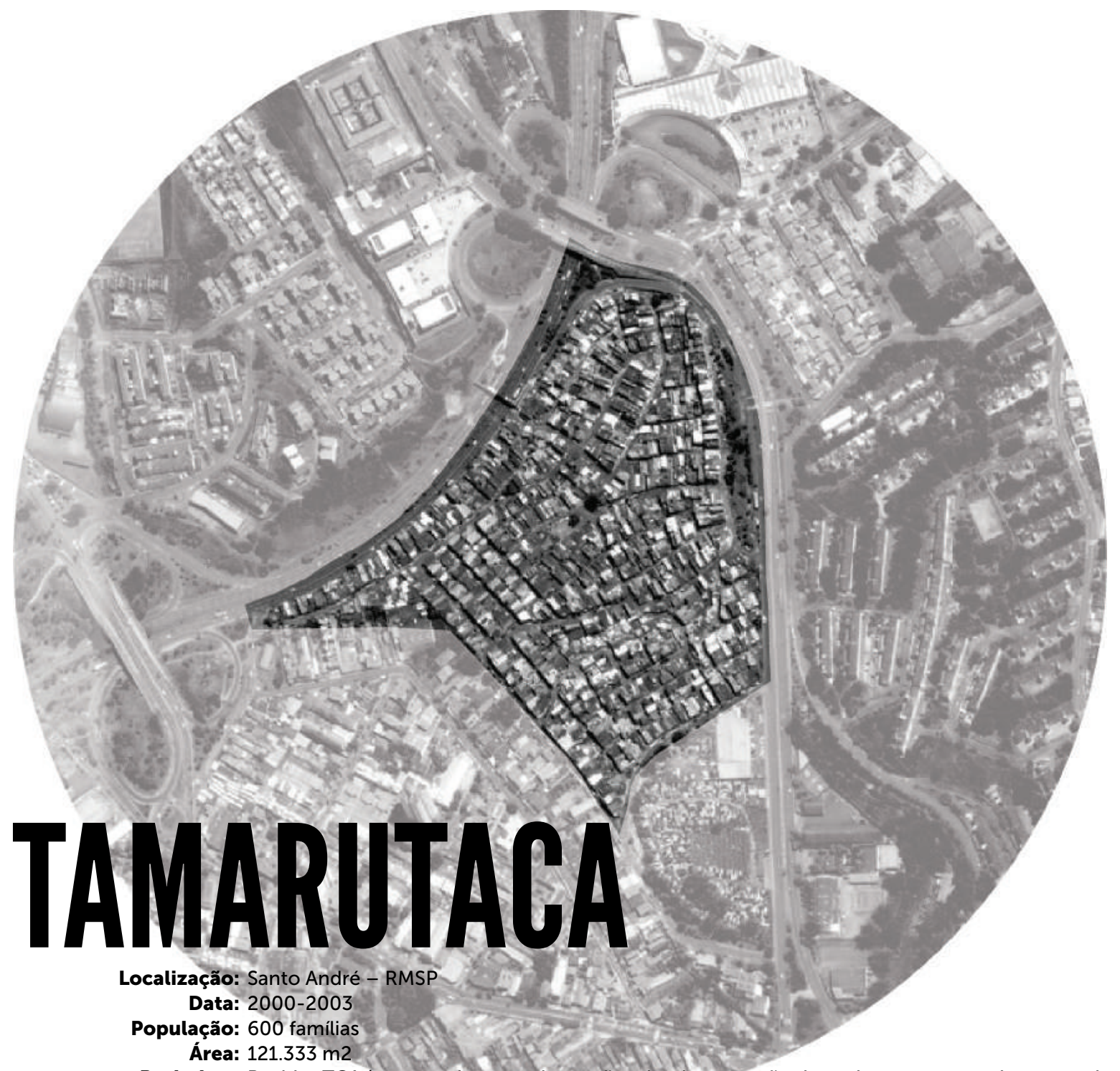

Projetista: Peabiru TCA (contratada para adequação e implementação de projeto e acompanhamento de obra)

Agente Organizador: Programa Integrado de Inclusão Social - PIIS / Santo André Mais Igual, Prefeitura Municipal de Santo André

Agente Financiador: PIIS / Santo André Mais Igual, Prefeitura Municipal de Santo André / Unidade de Gestão da União Europeia - BID

Valor: $\mathrm{R} \$ 4.653 .464,96$

Escopo: Assessoria técnica à urbanização (desenvolvimento de projetos de infraestrutura e viabilização de frentes de obra de infraestrutura e parcelamento) e autoconstrução (discussão, desenvolvimento de projetos e acompanhamento das obras) no núcleo.

Breve descrição: A equipe da Peabiru atuava junto ao Departamento de Habitação, no trabalho mais direto com a população para urbanização e construção das habitações no Setor B da Tamarutaca. A Peabiru apoiava a liberação das frentes de obra de urbanização (escadarias, sistema viário e redes de infraestrutura), apoiando a gestão das realocações para casas de familiares ou para o alojamento provisório; no reparcelamento do assentamento, definição de critérios para reocupação juntamente com as famílias; elaboração dos projetos das moradias que seriam executadas em regime de autoconstrução / autoempreendimento; e, por fim, acompanhamento técnico das obras. No último ano e meio de atuação da Peabiru, foram realizadas também algumas melhorias habitacionais envolvendo as moradias já consolidadas do assentamento.

Atividades realizadas: Acompanhamento de obra, adequação de projeto, assessoria para a construção de moradias.

Observações: A Peabiru foi contratada via administração direta. A intervenção terminou quando terminaram os recursos financeiros, mesmo que a intervenção não tenha sido totalmente concluída. 

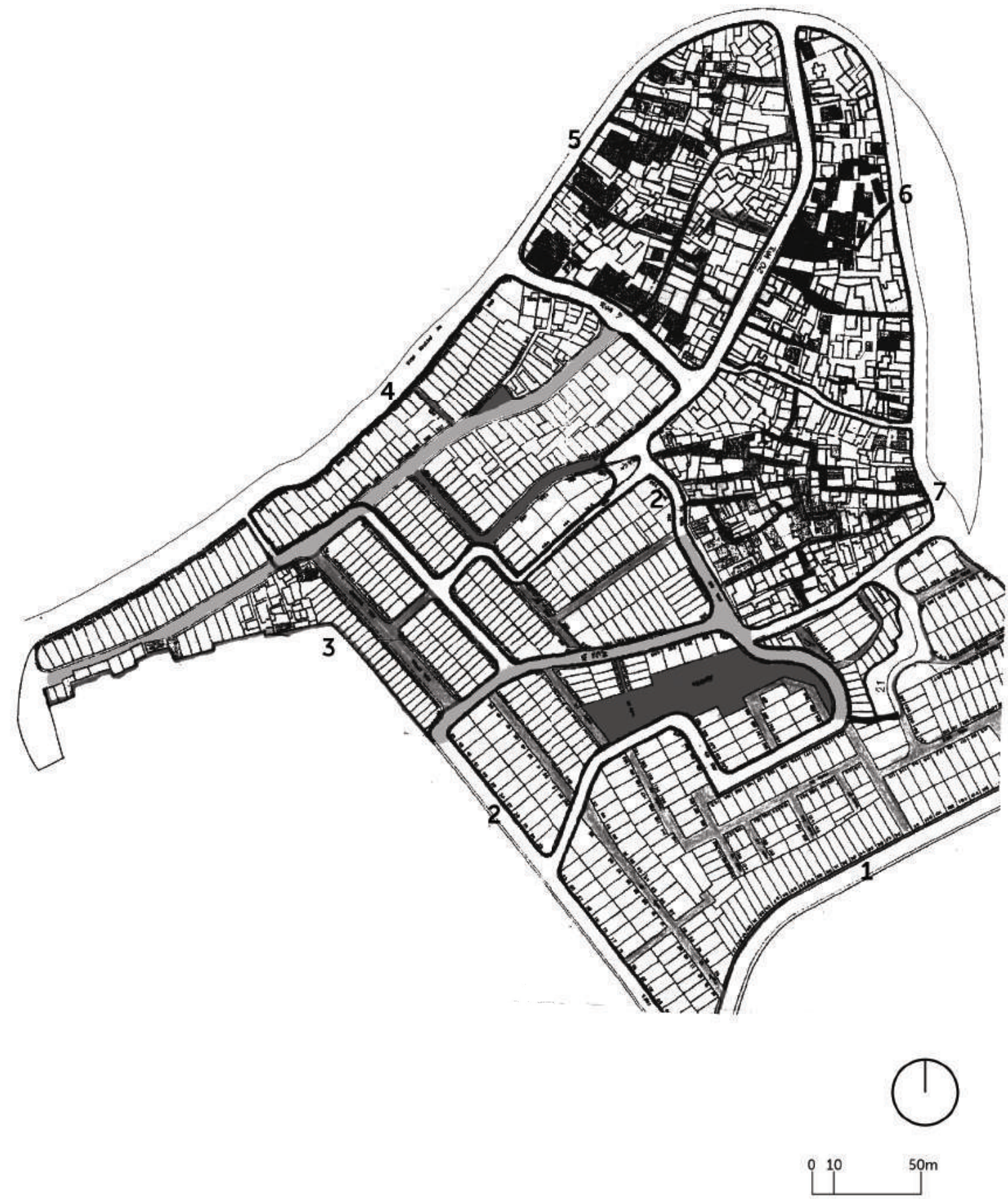

\section{Síntese de Levantamento da Tamarutaca}

Desenho elaborado a partir do levantamento da Tamarutaca disponibilizado pela Peabiru TCA. No desenho identifica-se a região de intervenção para coordenação da Peabiru - área mais irregular da favela. Esta favela já tinha tido intervenção pública restando apenas uma parte a implantar.

Elaboração: Bárbara Muhle sob coordenação da autora

Fonte base: cedida por Peabiru TCA

(página anterior: Destaque da favela Tamarutaca, Santo André, sobre fotografia aérea atual, Google Earth, 2016. Elaboração: Bárbara Muhle sob coordenação da autora) 


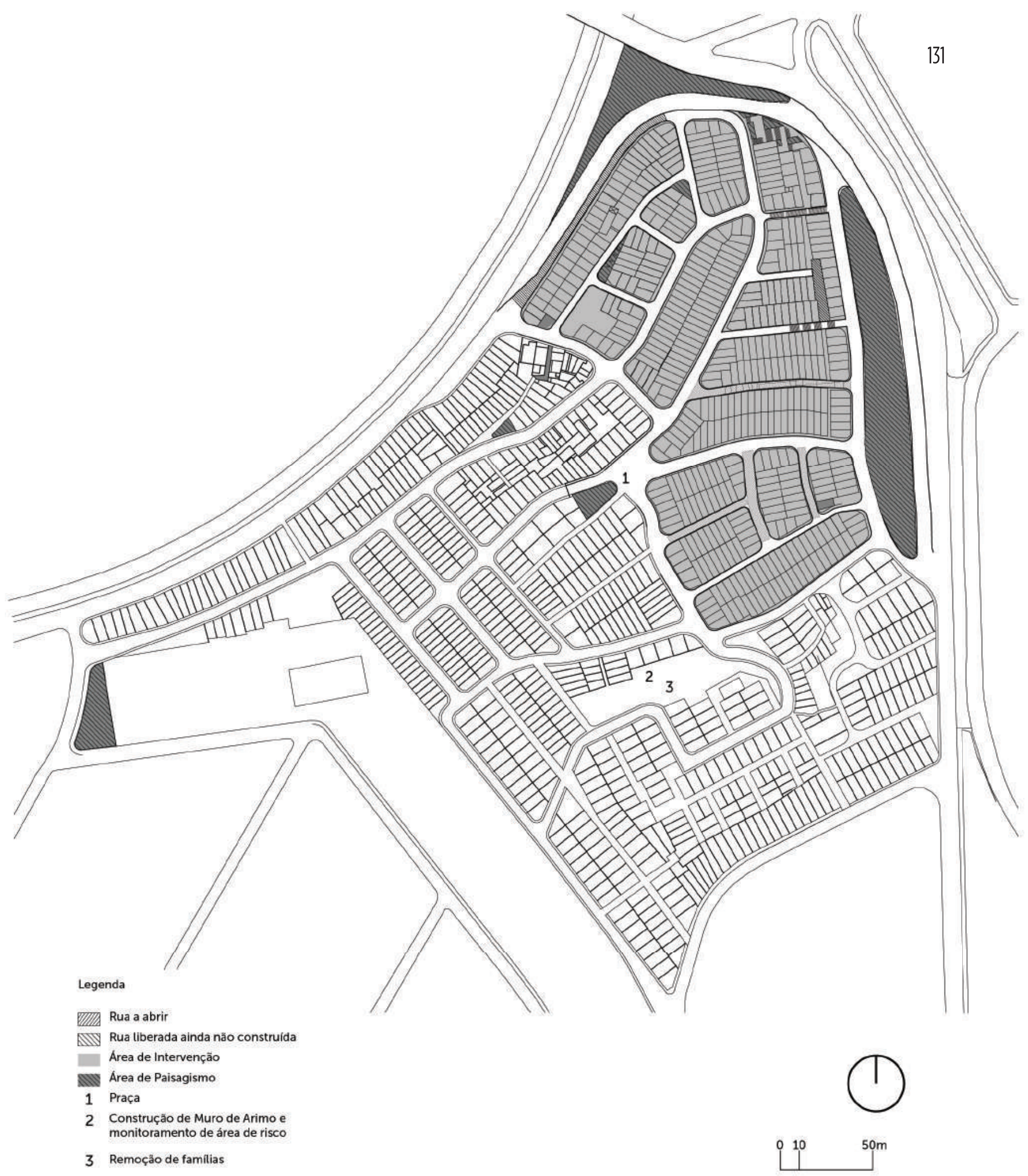

Síntese de Projeto Final da Tamarutaca

Desenho elaborado a partir do projeto final da Tamarutaca disponibilizado pela Peabiru TCA. O desenho demonstra um intervenção que partiu dos princípios do reparcelamento regularizado. Na intervenção, procurou-se manter o máximo de edificações já existentes, havendo a necessidade de algumas remoções totais ou parciais, para abertura das vias. Elaboração: Bárbara Muhle sob coordenação da autora Fonte base: cedida por Peabiru TCA 


\section{6-2009 JARDIM SILVIO SAMPAIO, SEMUDUH - PMTS, TABOÃO DA SERRA RMSP}

Mesmo sem acesso a grandes recursos e programas públicos, na RMSP os municípios continuaram a desenvolver algumas experiências progressistas. Alguns através de linhas de financiamento federal disponibilizadas outros com os próprios recursos disponíveis. Em Taboão da Serra, no período de 2005 a 20 I 2 , em duas gestões consecutivas do PSB (Partido Socialista Brasileiro), foi criada a Secretaria Municipal de Meio Ambiente, Desenvolvimento Urbano e Habitação (SEMUDUH), que definiu como prioridade a intervenção em assentamentos precários. Na época Heloisa Diniz Rezende, passa a fazer parte do quadro técnico em 2006. A ação da secretaria direcionou-se num primeiro momento para os assentamentos que já teriam recursos alocados e aprovados. (REZENDE, 20 I 5 )

Em 2006 Heloisa Rezende começou a acompanhar a intervenção na comunidade Silvio Sampaio, uma pequena favela que previa na sua intervenção a canalização de um córrego. O projeto foi desenvolvido pelos próprios técnicos da prefeitura que desenvolviam projeto à medida que acompanhavam a obra, aprendendo na prática a lidar com as metodologias e técnicas de urbanização em favelas. Para além do acompanhamento de obra e desenvolvimento dos projetos urbanos, a equipe disponibilizava um atendimento individualizado na área, o que facilitava o conhecimento aprofundado pelas questões físicas, mas também sociais de sua comunidade, e desconstruía o habitual afastamento entre população e órgãos públicos. (REZENDE, 20 I 6, informação verbal $\left.{ }^{36}\right)$

Embora os recursos disponibilizados se restringissem às ações acima descritas, através do Plantão Social [ ], instalado em um equipamento pú- blico, a população solicitava outros atendimentos, especialmente orientações para a realização de melhorias habitacionais. Os trabalhos em campo se concentravam no mapeamento e vistorias das casas por interface com a infraestrutura proposta, mas a partir da nova demanda ampliava-se a realização de vistorias, pelas quais foi possivel detectar problemas recorrentes, como trincas, rachaduras, problemas de insalubridade, infiltrações etc.

Para as casas que seriam retificadas, os projetistas, através de desenhos tridimensionais individualizados, propunham não a reposição de área construída e sim a acomodação do programa de usos da moradia pela família, processo finalizado somente a partir da concordância com o projeto dos moradores atendidos. As reformas das moradias foram planejadas para serem executadas por uma equipe de trabalhadores do local, que seriam envolvidos em atividades de formação em construção civil e cooperativismo, e em legislações de uso e ocupação do solo e normas de construção, com o objetivo de qualificá-los para atuar localmente, orientando a população à regularidade. (REZENDE, 2015, p.73)

\author{
36. Entrevista realizada \\ em I7/Io/20I6, São \\ Paulo.
}




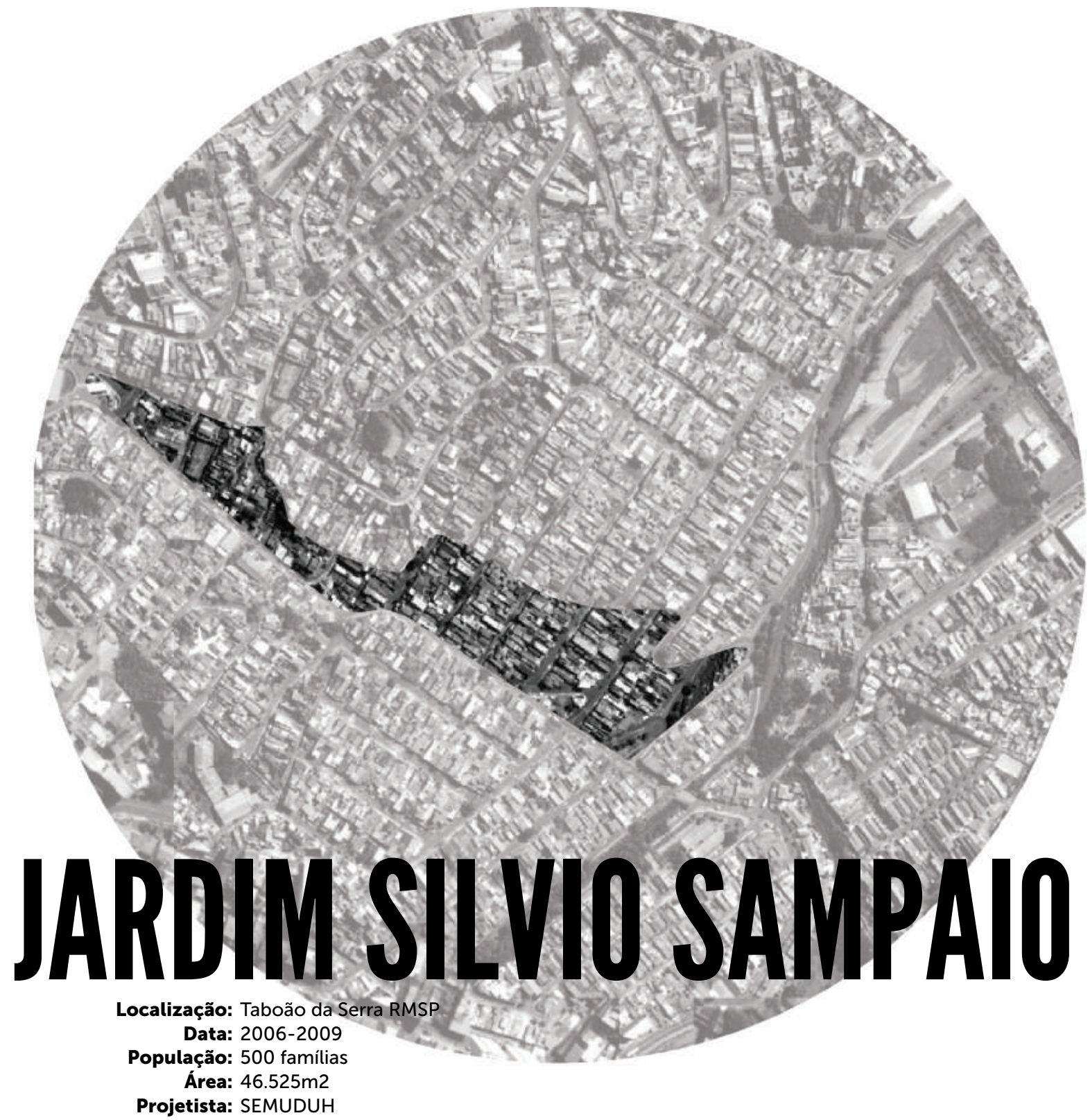

Agente Organizador: Secretaria Municipal de Meio Ambiente, Desenvolvimento Urbano e Habitação (SEMUDUH), Prefeitura Municipal de Taboão da Serra

Agente Financiador: SEMUDUH, Prefeitura Municipal de Taboão da Serra, Pró-Moradia e OGU/FNHIS Valor: R\$1.907.000,00

Escopo: Melhorias urbanas e de infraestrutura. Melhorias habitacionais.

Breve descrição: Execução da rede de esgoto e de complementação da rede de drenagem, e reassentamento das famílias removidas; Retificação de 65 casas, garantindo o afastamento mínimo necessário em relação ao córrego, exigido pelas normas da concessionária, e construção de 28 novas unidades, para reassentar famílias que seriam removidas nesse processo de adequação das moradias.

Atividades realizadas: Canalização de córrego e implementação de sistema de esgoto sanitário. Readequação de habitações afetadas. Assessoria individual para a adequação e construção habitacional

Valor: $\mathrm{R} \$ 1.657 .968,75$

Observações: A intervenção em Silvio Sampaio e de outras experiências simultâneas no município fomentam a possibilidade discussão sobre a intervenção através de melhorias habitacionais dentro da equipe técnica da secretaria.

Em 2012 estimava-se que a intervenção tinha sido implementada em 60\% da sua previsão. 


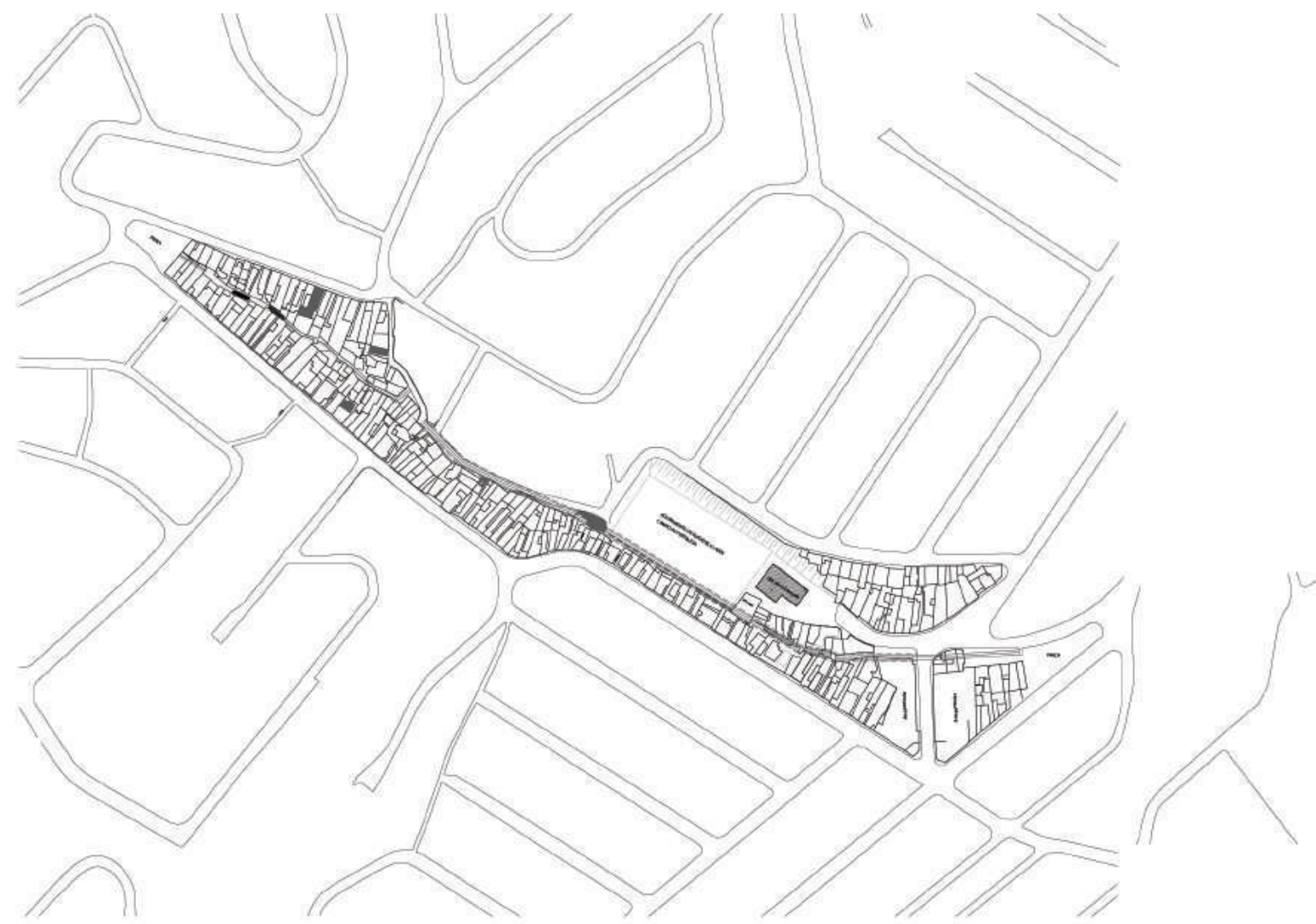

LEGENDA

EQUIPAMENTO DE ESPORTES E LAZER

ZA UBS - EQUIPAMENTO DE SAÚDE - PSF

CASAS

QD FAIXA NON AEDIFICANDI

- FAIXA DE SERVIDÃO

CORREGO CANALIZADO

REMOÇAO TOTAL- 15 unidades

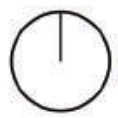

$010 \quad 50 \quad 100 \mathrm{~m}$

\section{Síntese de Levantamento e Diagnóstico do Jardim Silvio Sampaio}

Desenho elaborado a partir de desenhos disponibilizados por Heloisa Rezende. O projeto de intervenção urbana, implicava a introdução infraestrutura de saneamento e drenagem. No levantamento realizado pelos técnicos da Prefeitura identificam-se as edificações necessários a remover para a instalação da obra, mas também aquelas mais precárias e que tiveram assessoria de projeto para a sua reconstrução.

Elaboração: Bárbara Muhle sob coordenação da autora

Fonte base: cedida por Heloisa Rezende

(página anterior: Destaque da favela Jardim Silvio Sampaio, Taboão da Serra, sobre fotografia aérea atual, Google Earth,

2016. Elaboração: Bárbara Muhle sob coordenação da autora) 


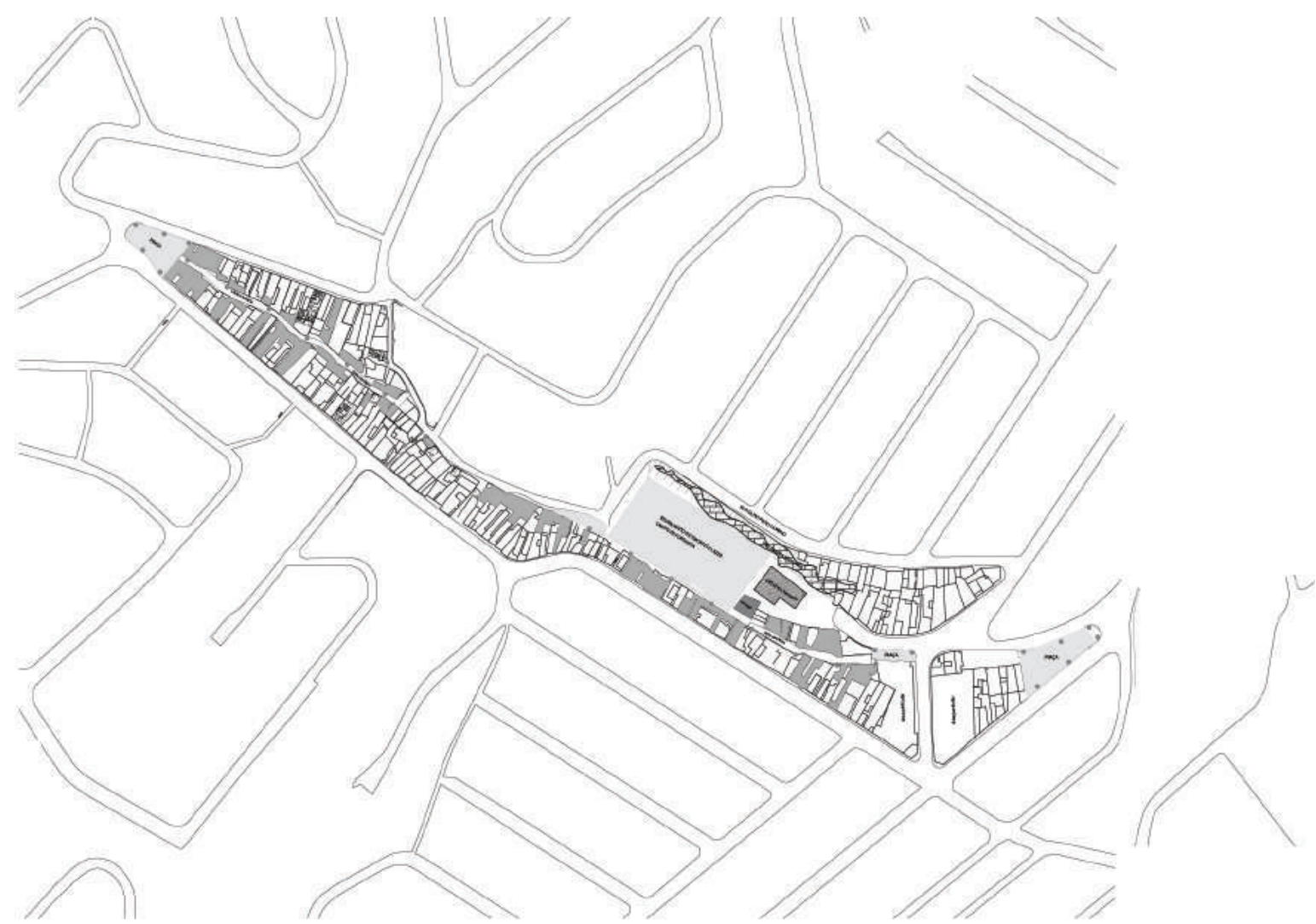

LEGENDA

EQUIPAMENTO DE ESPORTES E LAZER

7 UBS - EQUIPAMENTO DE SAÚDE - PSF

PRAÇAS ( 3 unidades) E AREAS VERDES

MELHORIAS HABITACIONAIS

[19 NOVAS UNIDADES- 31 unidades

ESPAÇO MULTIUSO

FAIXANON AEDIFICANDI

- FAIXA DE SERVIDÃo

- ILUMINAÇÃO PÚBLICA PROPOSTA -33 unidades

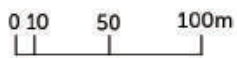

\section{Síntese de Projeto de Intervenção do Jardim Silvio Sampaio}

Desenho elaborado a partir de desenhos disponibilizados por Heloisa Rezende. Neste desenho estão identificadas as novas habitações desenhadas pelos técnicos da prefeitura para a reassentamento das famílias atingidas na mesma área, mas também as habitações que receberiam melhorias habitacionais. Também as praças e áreas públicas tiveram projeto específico de intervenção.

Elaboração: Bárbara Muhle sob coordenação da autora

Fonte base: cedida por Heloisa Rezende 


\section{6-2009 JARDIM SANTO ONOFRE, BND ARQUITETOS, SEMUDUH - PMTS, TABOÃO DA SERRA, RMSP}

O conhecimento acumulado em projetos menores, tais como a intervenção na favela Silvio Sampaio e a entrada de um novo grupo de assentamentos previstos para urbanização, levam à decisão de contratação de equipes projetistas para casos mais complexos, cabendo à equipe pública a gestão e acompanhamento dos processos. Optou-se pela contratação de assessorias técnicas, a Peabiru TCA (Morro do Sabão), a Ambiente Arquitetura (Jardim São Judas) e o escritório BND Arquitetos de Milton Nakamura por reconhecerem nestas organizações e técnicos formas de atuação que privilegiavam um relacionamento aproximado e importância dada às comunidades, assim como leituras e desenhos que potencializavam questões sociais, o que a gestão reconhecia como importante para lidar com assentamentos precários. (REZENDE, 20 I6, informação verbal ${ }^{37}$ )

O levantamento em campo individualizado das 200 moradias do Jd Santo Onofre foi realizado por equipe de dois arquitetos e três estagiários em uma semana de trabalho, o que permitiu classificar as diversas patologias construtivas e agrupá-las para orientar projetos específicos. (...)

projeto mantinha as características do conjunto edificado pelos moradores, ora substituindo-o, ora

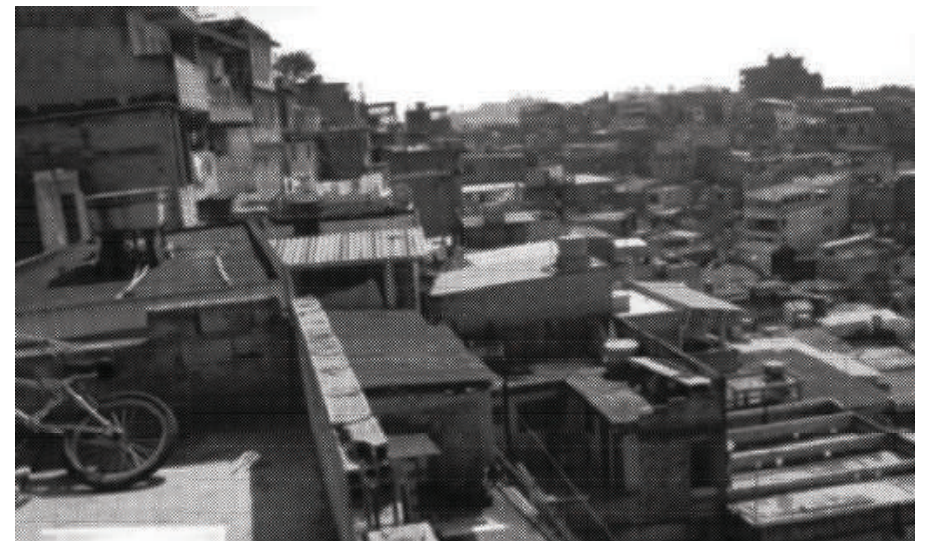

propondo novas soluções para eliminar precariedades, incorporando em grande medida alternativas similares às realizadas pela própria população e potencializando-as, como, por exemplo, o projeto para a laje de cobertura de um dos edifícios (bloco 4), em alusão às lajes de coberturas das casas que, através do conceito de "solo criado", constroem áreas alternativas aos quintais que possibilitam usos privativos variados. (REZENDE, 2016, p. 44 e 49)

Como críticas, Rezende reconhece um problema a necessidade da 'invenção da roda' no caso do quadro técnico menos experiente e por isso menos capacitado ${ }^{38}$ para a urbanização de favelas. Por fim, o processo de contratação e implementação de obra dos projetos desenvolvidos pelas assessorias e escritório, acabou por ser questionado e em determinado momento parado por ir contra alguns interesses mais econômicos e menos sociais, dentro do município, no caso a necessidade de resposta a compromissos clientelistas por oposição à uma atuação idónea por parte da prefeitura seus técnicos e as decisões por eles tomadas (REZENDE, 20 I 6, informação verbal ${ }^{39}$ ). fig. 9 Vista do Jardim Santo Onofre, Taboão da Serra. Fonte: cedida por Heloisa Rezende.
37. Entrevista realizada em I7/I I/20I6, São Paulo.

38. É recorrente nos depoimentos a reclamação sobre a formação insuficiente dada nas faculdades ou outros processos formativos em arquitetura e urbanizamos para lidar com a questão favela e que vamos reforçando ao longo desta exploração. 39. Entrevista realizada em I7/Iо/2016, São Paulo. 


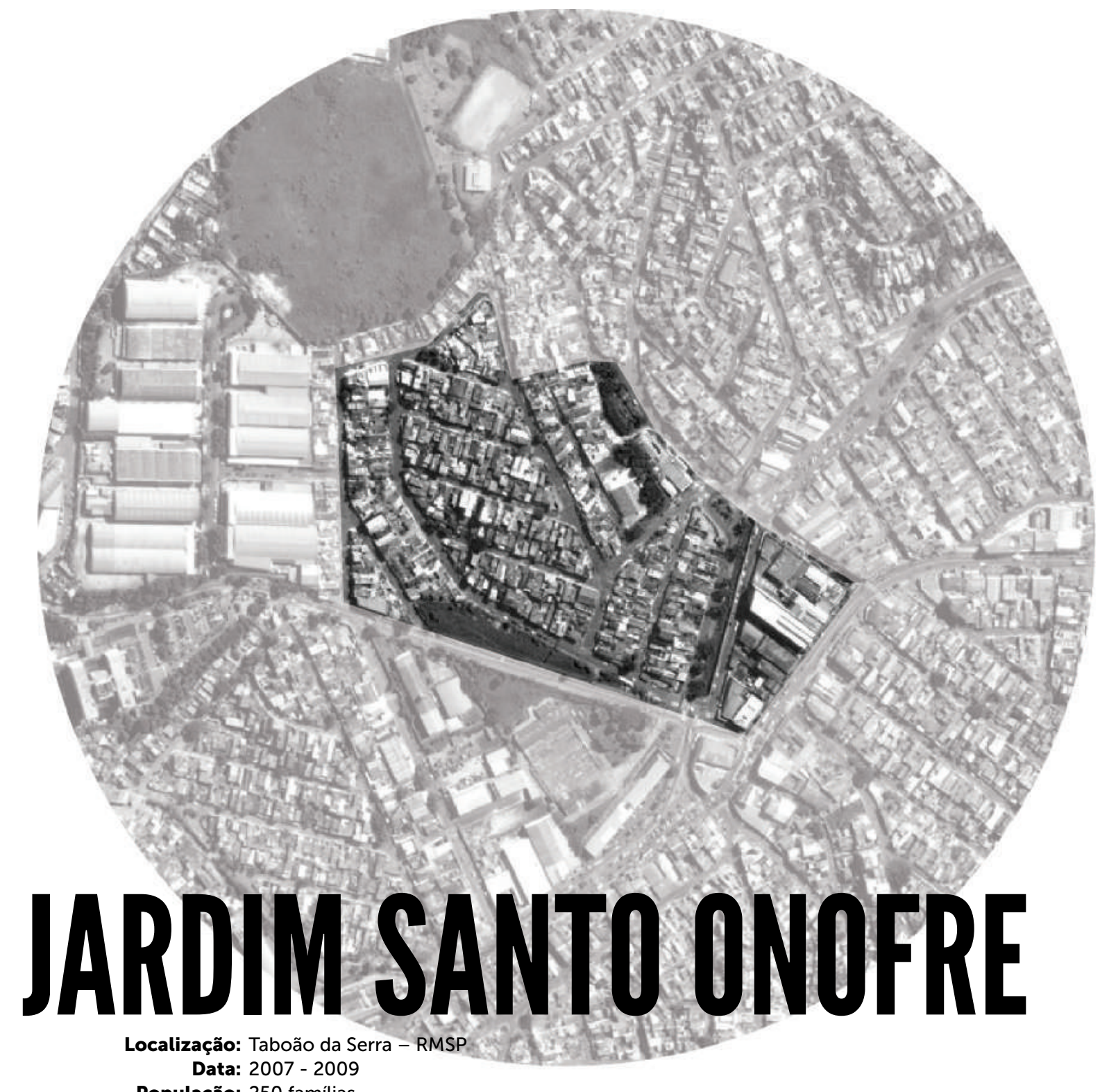

População: 250 famílias

Área: $10.5000 \mathrm{~m} 2$

Projetista: BND Arquitetos (atual Barossi Nakamura Dedecca Arquitetos)

Agente Organizador: Secretaria Municipal de Meio Ambiente, Desenvolvimento Urbano e Habitação - SEMUDUH, Prefeitura Municipal de Taboão da Serra - PMTS

Agente Financiador: SEMUDUH, PMTS, FNHIS

Outros agentes: Cadastro socioeconômico realizado pela empresa Labour Consult

Escopo: Diagnóstico, Projeto urbanístico, coordenação de projetos complementares. Projeto de arquitetura de novas unidades habitacionais. Projeto de melhorias habitacionais.

Breve descrição: Área pública pertencente ao sistema de recreio do loteamento de mesmo nome, formado por uma encosta íngreme. O levantamento em campo foi individualizado com classificação de cada moradia por critérios de precariedade. Para além do levantamento de dados, foram realizadas conversas, reuniões e assembleias para discussão e apresentação das propostas num modelo participativo.

Atividades realizadas: Levantamentos, diagnósticos e projetos.

Observações: Mesmo com a seleção do projeto para financiamento via PAC-1, este acabou por não ser implementado. 

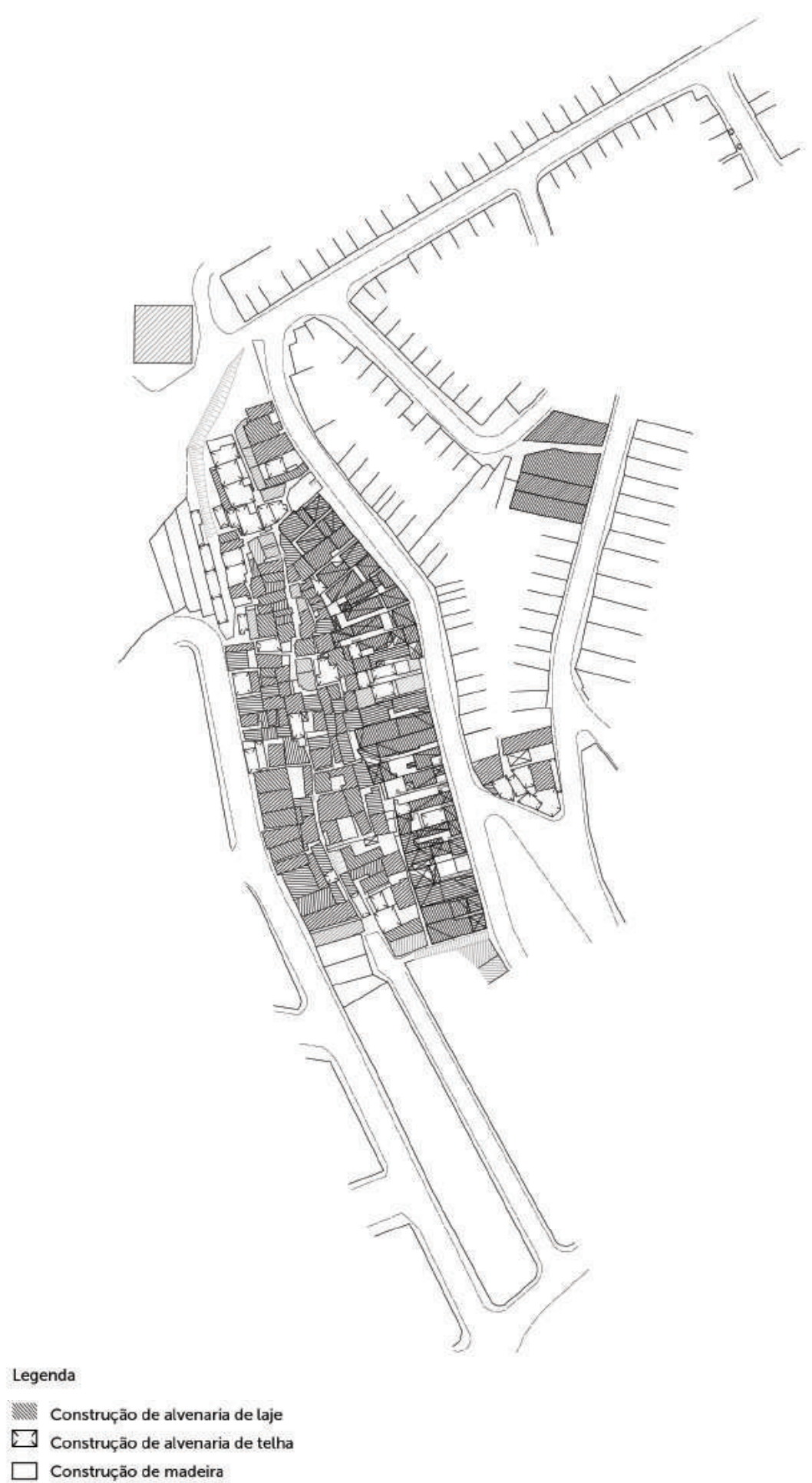

\section{Síntese de Levantamento do Jardim Santo Onfre}

Desenho elaborado a partir de desenhos disponibilizados por Milton Nakamura. $\bigcirc$ desenho revela um levantamento detalhado realizado casa-a-casa. É possível verificar a densidade de ocupação territorial, numa área onde se destaca a declividade do terreno

Elaboração: Bárbara Muhle sob coordenação da autora

Fonte base: cedida por Milton Nakamura

(página anterior: Destaque da favela Jardim Santo Onofre, Taboão da Serra, sobre fotografia aérea atual, Google Earth, 2016. Elaboração: Bárbara Muhle sob coordenação da autora) 


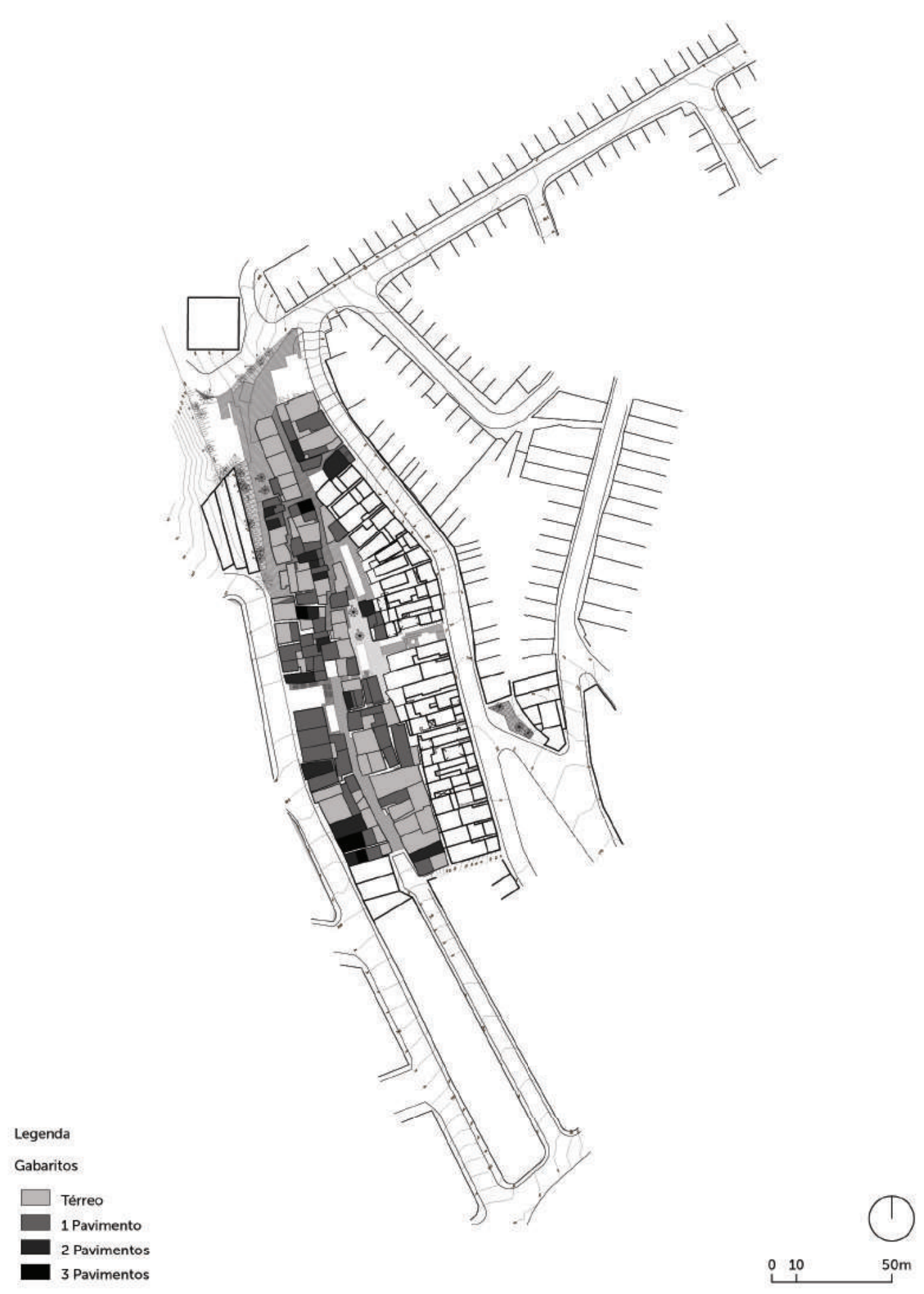

\section{Síntese de Projeto de Intervenção do Jardim Santo Onofre}

Desenho elaborado a partir de desenhos disponibilizados por Milton Nakamura. No desenho identifica-se a área de intervenção de projeto, com proposta de construção de unidades habitacionais e redesenho de espaços públicos. No desenho em planta do projeto mantém-se as informações de levantamento (número de pavimentos das construções) o que indica a sua importância para o definição da intervenção proposta. O projeto não chegou a ser implementado. Elaboração: Bárbara Muhle sob coordenação da autora 


\section{A PARTIR DE 2003}

\section{GOVERNO LULA. MINISTÉRIO DAS CIDADES. PAC UAP}

A aprovação do Estatuto da Cidade (200I), a chegada de Lula ao governo e a criação do Ministério das Cidades (2003), pareciam ensejar as conquistas tão ambicionadas da luta pela Reforma Urbana ${ }^{40}$. Os investimentos públicos de foro desenvolvimentista surgem como estruturais no governo petista e possibilitam o desenvolvimento econômico e social do país alcançando os mais pobres com subsídios, programas e legislações (a facilidade de acesso a crédito, os programas federais com o Programa de Aceleração do Desenvolvimento - PAC, e o Programa Minha Casa Minha Vida PMCMV) como nenhum outro governo anterior tinha conseguido (PETRAROLLI, 2015). Apesar de possibilitar a melhoria de vida de grande parte da população através da via econômica, este modelo de desenvolvimento, num momento de crise como o que vivemos hoje, se demonstra insustentável.

Com a chegada ao Governo de um partido de fundo progressista e próximo das reivindicações das classes sociais mais baixas o PT Partido dos Trabalhadores, em relação à intervenção em assentamentos precários houve a vontade de generalizar as experiências das gestões municipais progressistas dos anos 80 e 9o. Muitos dos técnicos com experiência dessa época vão compor os primeiros quadros do Ministério das Cidades, e propõe metodologias, programas e linhas de atuação que olham para os assentamentos informais precários e procuram possibilitar a sua intervenção no sentido de aglomerados territoriais mais justos.

No seu lançamento, o PAC abre uma linha atuação direcionada apenas para Urbanização de Assentamentos Precários - PAC UAP. Nunca em outro momento da história, houve tanto recurso financeiro disponível para a intervenção em favelas como nesse momento (PETRAROLLI, 20 I 5 ). No entanto, em $\mathrm{I} \circ$ anos de experiência ainda não conseguimos avançar no sentido de encontrar soluções totalmente eficazes para a questão. $\mathrm{O}$ recurso disponibilizado pelo $\mathrm{PAC}$ não teve o efeito esperado. O Programa apresenta-se na constituição como um programa de certa forma conservador (LEITÃO, 2009), pela dificuldade burocrática, o seu acesso foi concentrado em alguns polos urbanos que já tinham algum conhecimento na intervenção em favelas e em gestão de programas e recursos federais (PETRAROLLI, 20 I 5). Reconhece-se hoje as diferentes realidades contidas dentro do mesmo país, quer no que diz respeito às características de precariedade habitacional, como de conhecimento técnico adquirido e, acima de tudo, das soluções para a diversidade de problemas, e que, portanto, um só programa nacional não consegue abarcar. Além disso, o PAC, como programa público, reforça as habituais formas de contratação, facilitando a entrada das grandes empresas, construtoras, gerenciadoras, etc., mas que como empresas que são, visam o lucro e não o desenvolvimento de processos que potencializem a melhor adequação de soluções para uma questão que é tão complexa como as favelas.

Ainda assim esta quantidade de recursos possibilitou intervenções, algumas de grande escala, nos últimos anos. As experiências foram realizadas tanto por gestões mais conservadoras como por outras mais progressistas. Neste quadro, selecionamos 4 delas para explorar a atuação dos projetistas militantes neste último período que abordamos até aos dias de hoje.

\author{
40. Movimento social \\ surgido no periodo \\ de redemocratização \\ no Brasil e reinvini- \\ dava justiça sociale \\ territorial através de \\ pautas especificas a \\ serem implementadas \\ através de legislação, \\ programas politicose \\ intervenções públicas. \\ A sua organização \\ tornou-se oficinal em \\ 1987 através da criação \\ do FNRU - Fórum \\ Nacional da Reforma \\ Urbana-formado por \\ ONGs, entidades profis- \\ sionais e movimentos \\ populares, contribuindo \\ ativamente para a \\ elaboração da Constitu- \\ ição de I 988 , e para a \\ aprovação do Estatuto \\ da Cidade (200I). \\ 4I. As intervenções em \\ favelas eram habitual- \\ mente responsabilidade \\ de intervenção da gestão \\ municipal no Rio de \\ Janeiro, mas que desdeo \\ Programa Favela-Bairro, \\ tinha esmorecido em \\ propostas de intervenção \\ de grande escala. \\ 42. Ver Vila Olímpica da \\ Rocinha, em Currículo \\ de Luiz Carlos Toledo \\ em Parte I, Cap. o I. \\ 43. Entrevista realizada em \\ 23/ I I/20 I 5, São Paulo.
}




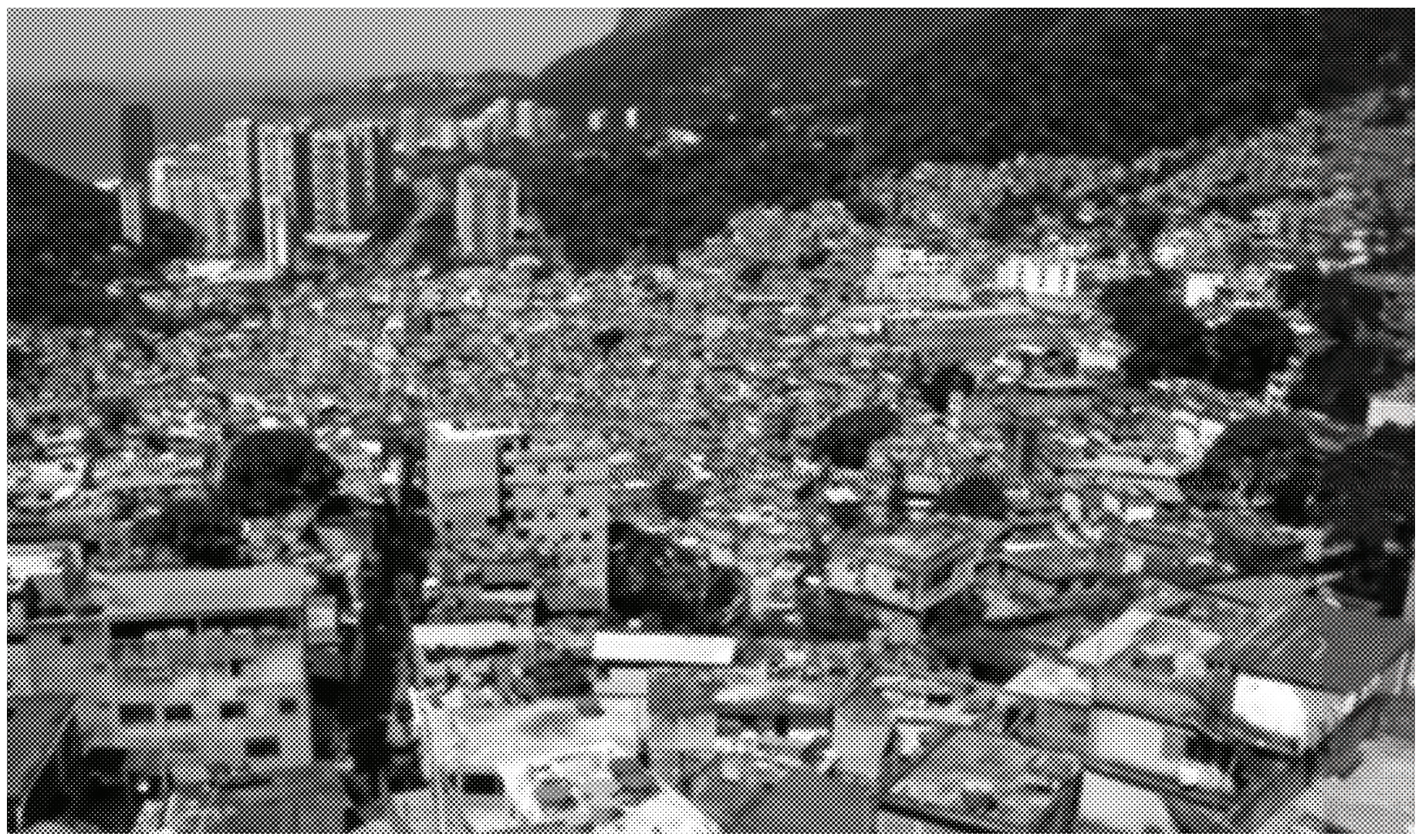

fig. 10 Vista Geral da Rocinha, Rio da Janeiro.

Fonte: cedida por Jonathas Silva.

\section{5-2009 PLANO SOCIO-ESPACIAL DA ROCINHA, MAYERHOFER \& TOLEDO - M\&T ARQUITETOS, EM COLABORAÇÃO COM MPS ASSOCIADOS, RIO DE JANEIRO}

O Concurso de Ideias para Urbanização da Rocinha foi lançado em 2006 pelo Governo Estadual do Rio de Janeiro em colaboração com o IAB-RJ. Num período onde o Governo aproveitou uma janela de oportunidade pois a gestão municipal tinha parado de atuar de forma política e programática em favelas ${ }^{41}$. A Rocinha é considerada uma das favelas maiores do Rio de Janeiro, e portanto a possibilidade de atuação neste contexto acarretava uma carga propagandística associada. No cenário de escassez de recursos e oportunidades de trabalhar com favelas são submetidas várias propostas no concurso. Vence o escritório do arq. Luiz Carlos Toledo, M\&T Arquitetos, desta vez com a sua participação ativa, e com a colaboração de Jonathas Magalhães e Vera Tângari. A proposta de Manoel Ribeiro fica em segundo lugar.

$\mathrm{O}$ grupo dirigido por Toledo inicia o seu contato com a comunidade da Rocinha ainda antes de vencerem o concurso. Na verdade, a participação no concurso teria sido instigada por moradores que já conheciam Toledo de outro projeto ${ }^{42}$ e que também vão integrar a sua equipe de trabalho. (TOLEDO, 20 I 5 , informação verbal ${ }^{43}$ )

Destacamos algumas questões que enquadram esta como uma experiência de arquitetos militantes. Os projetistas só seriam contratados 2 anos após o concurso para desenvolvimento do projeto e dada a fragilidade de conhecimento técnico do Governo de Estado sobre o assunto, foi a própria equipe projetista que definiu o seu escopo de trabalho para o desenvolvimento do processo (SILVA, 20 I 5 , informação verbal ${ }^{44}$ ). Isso só foi possível devido à grande experiência concentrada nos técnicos projetistas em 
desenvolvimento de processos públicos mas também sobre favelas. ${ }^{45} \mathrm{~A}$ participação foi um conceito chave em todo o processo. Iniciando-se no momento da elaboração da proposta para concurso, passando por moradores contratados para integrarem a equipe de trabalho, pelas assembleias realizadas ao longo de todo o processo para reconhecimento do território e suas problemáticas e para apresentação e discussão das soluções encontradas onde os técnicos participantes recorriam ao repertório acumulado de técnicas de mediação e trabalho de grupos ${ }^{4}$. Uma das iniciativas mais relevantes por parte da equipe, foi a abertura de uma filial do escritório dentro da comunidade e que permitiu um contato constante e aproximado com a população, isso permitia um acesso facilitado que os moradores utilizaram para retirar dúvidas e colocar questões aos projetistas e que acabavam por contribuir no desenvolvimento do projeto. Esta iniciativa foi totalmente assumida por Toledo. Para além disso, o arquiteto e também professor, organizou uma série de sessões/aulas de introdução ao urbanismo, inicialmente direcionada para a sua equipe, mas posteriormente frequentada por outros moradores da comunidade interessados. Foram também explorados e utilizados os recursos de mobilização e divulgação social já existentes na comunidade. Este processo possibilitou a apropriação e empoderamento por parte dos moradores que inclusive utilizaram o seu conhecimento na reinvindicação pela implementação do que havia sido proposto pela equipe. (SILVA, 2015 , informação verbal $^{47}$ e TOLEDO, 20 I 5, informação $\operatorname{verbal}^{48}$ )

No entanto, a ausência do poder público foi constante em todo o processo e, por este facto, em determinado momento desmobilizaram-se as assembleias regulares e o processo participativo. O lançamento do PAC UAP no meio do processo facilitou, por um lado, com recursos financeiros a viabilização tanto de projeto como de obra, por outro, introduziu uma nova agenda (política) que não estava inicialmente prevista. É o caso da tentativa de construção de um teleférico, proposta que surgiu por parte do poder público e não da equipe projetista ou da comunidade. (SILVA, 2015 , informação verbal $^{49}$ )

Por estas e outas contradições, a equipe projetista coordenada por Toledo e Jonathas Silva ausentou-se da etapa de obra. $\mathrm{Na}$ sua implementação e o projeto foi parcialmente alterado.

\footnotetext{
44. Entrevista realizada

em 26/10/2015, São

Paulo.

45. Como podemos verifi-

car pelas experiências

retratadas nos curricu-

los de Toledo, Vera Tân-

gari e Jonathas Silva, em

Parte I, Capitulo o I.

46. Jonathas tinha tra-

balhado na elaboração

de Planos Diretores por

todo o país e entrado em

contato com técnicas de

psicodrama para o tra-

balho em grupos, e Vera

recorria ao conhecimen-

to acumulado na sua

carreira, inclusive na

especialização realizada nos EUA. Experiências presentes nos currículos de Toledo, Vera Tângari e Jonathas Silva, em Parte I, Capitulo o I.

47. Entrevista realizada em 26/10/2015, São Paulo.

48. Entrevista realizada em 23/I I/2OI 5, São Paulo.

49. Entrevista realizada em 26/Io/2015, São Paulo.
} 


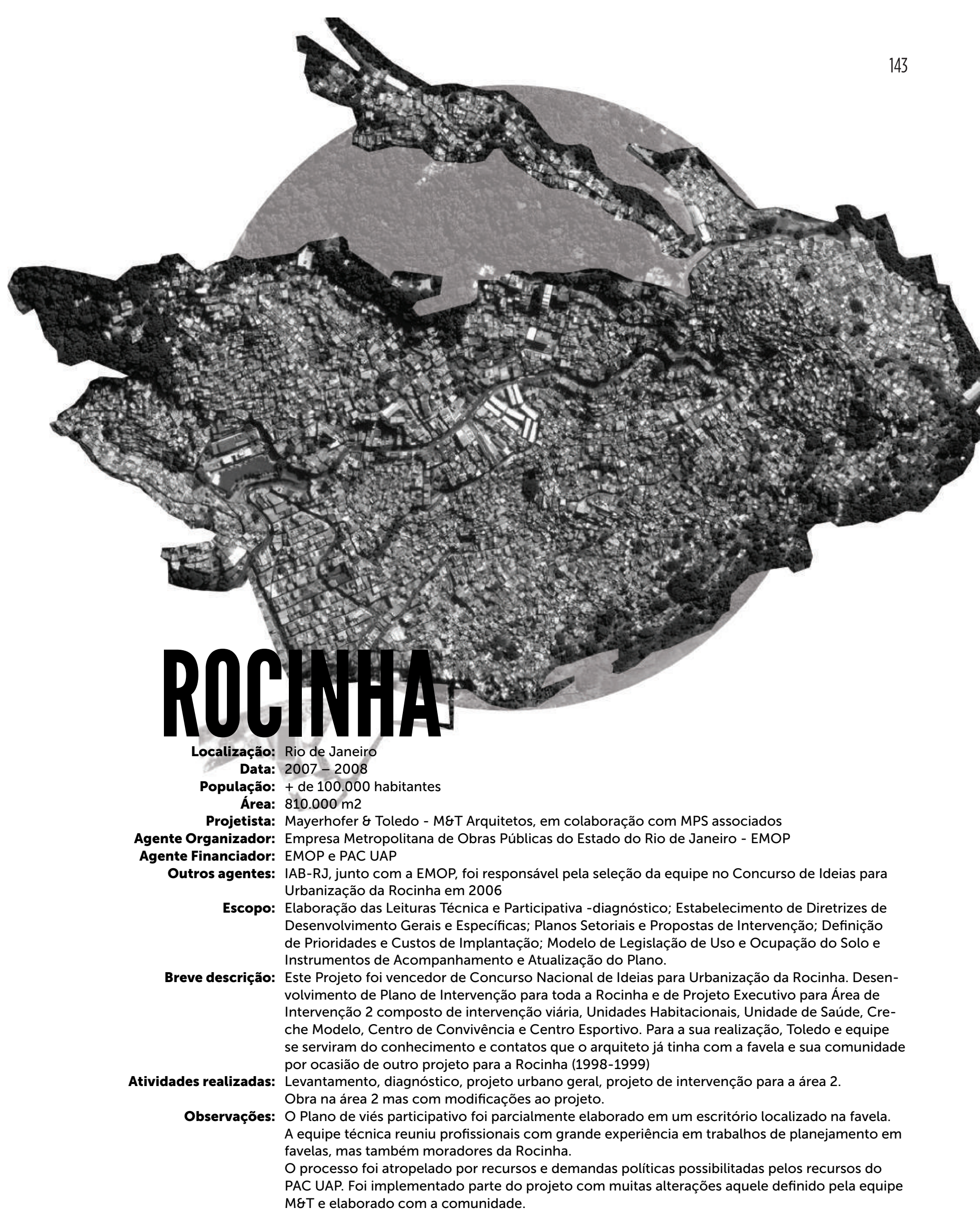




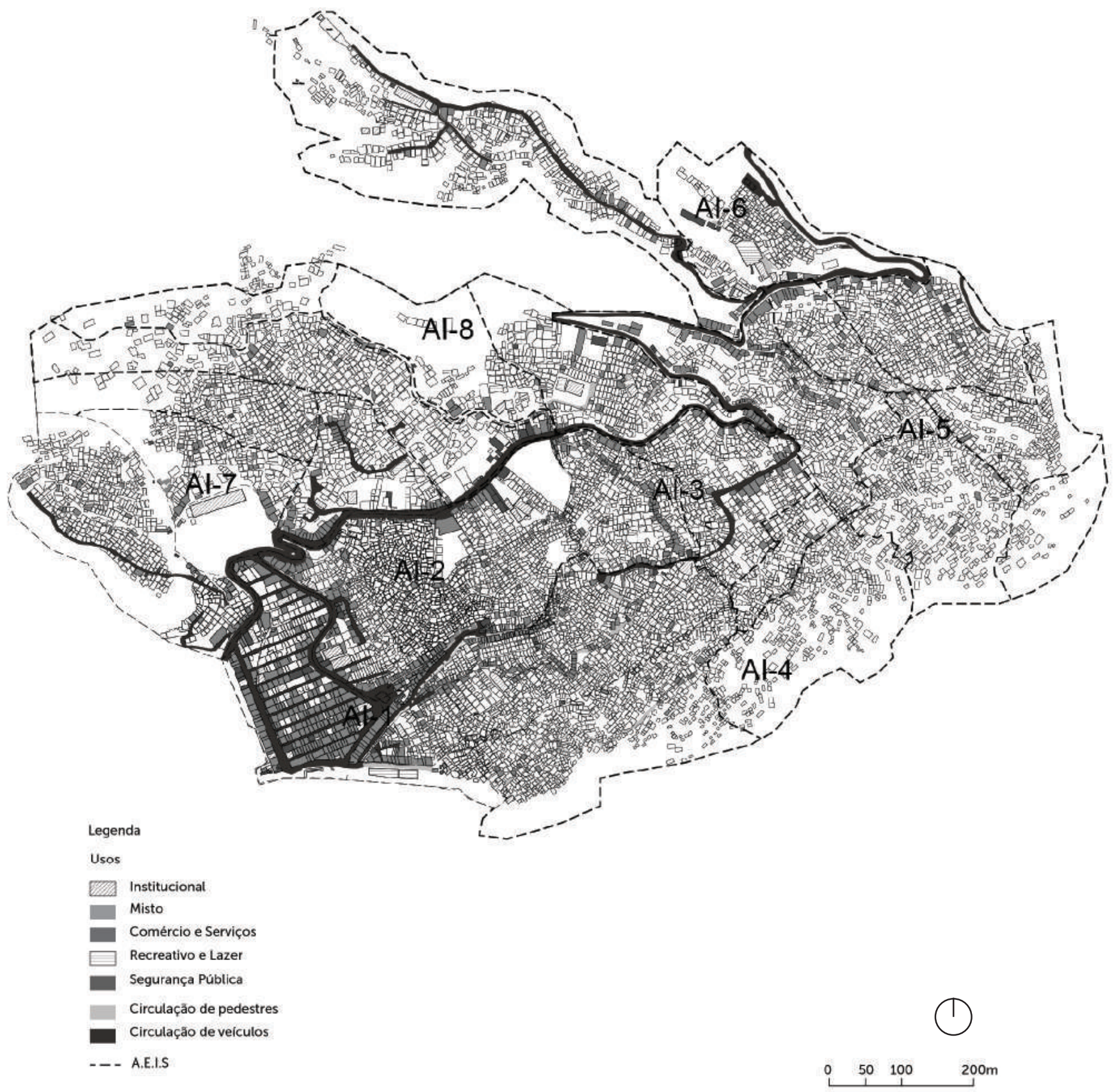

\section{Síntese de Levantamento da Rocinha}

Desenho elaborado a partir de desenhos disponibilizados por Jonathas Silva. No desenho identifica-se a divisão realizada pelos projetistas para efeitos de levantamento e intervenção, dado tratar-se de uma vasta área. Apesar da dimensão a equipe fez um levantamento exaustivo com o levantamento do número de pavimentos de todos os edifícios. Na imagem estão representadas as principais vias de circulação e os usos diferenciados.

Elaboração: Bárbara Muhle e Beatriz Nobumoto sob coordenação da autora Fonte base: cedida por Jonathas Silva

(página anterior: Destaque da favela Rocinha, Rio de Janeiro, sobre fotografia aérea atual, Google Earth, 2016. Elaboração: Bárbara Muhle sob coordenação da autora) 


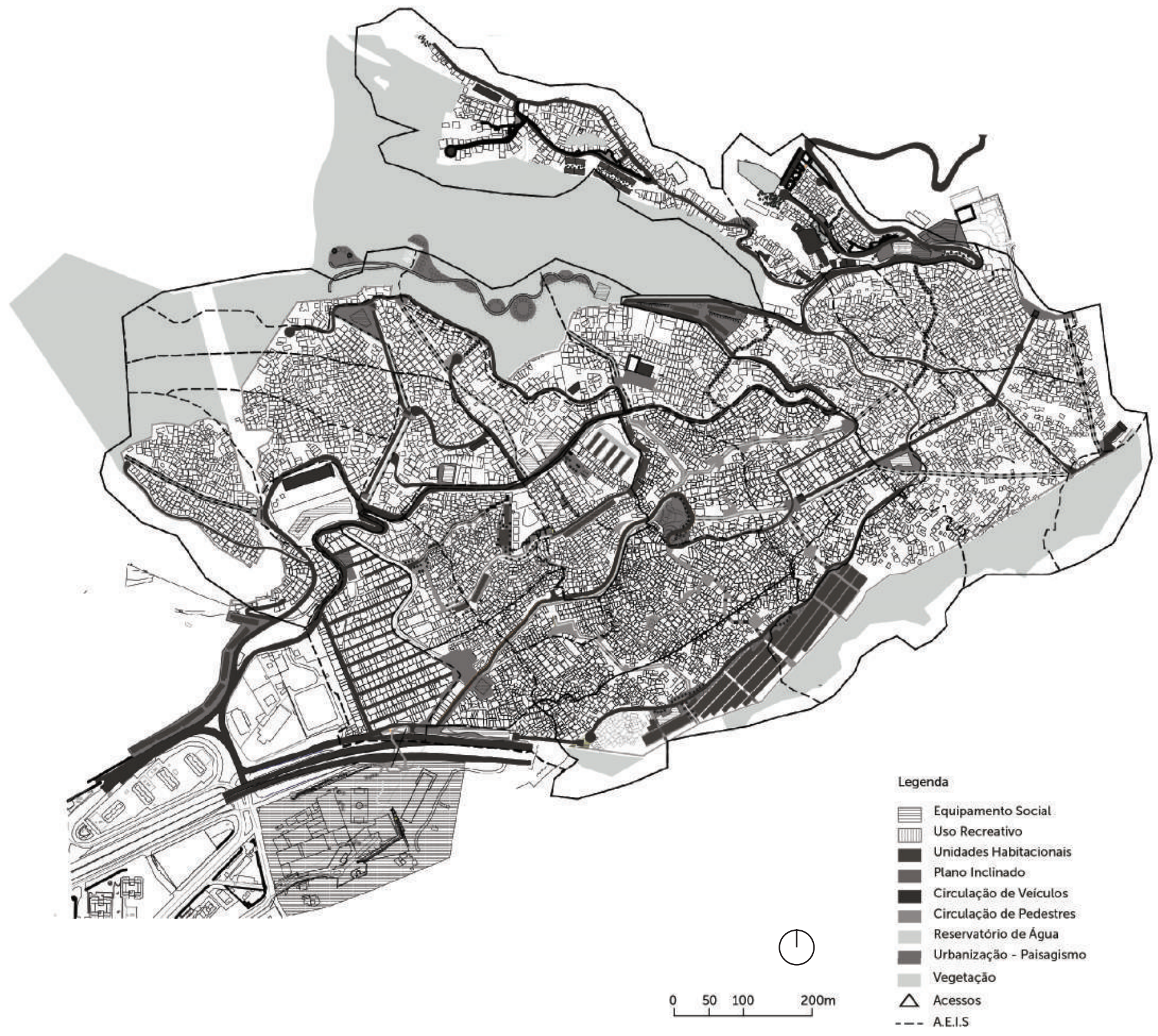

\section{Síntese do Plano de Intervenção da Rocinha}

Desenho elaborado a partir de desenhos disponibilizados por Jonathas Silva. Dada a densidade de ocupação da Rocinha, os grandes projetos de edificação propostos localizam-se nas bermas da favela ou nos espaços livres existentes. Há uma reduzida proposta de remoção para ampliação e abertura de vias assim como vários projetos de novas unidades habitacionais e ligações de vias inexistentes. O projeto foi parcialmente implementado, sobre o qual houve várias modificações. Elaboração: Bárbara Muhle e Beatriz Nobumoto sob coordenação da autora

Fonte base: cedida por Jonathas Silva 


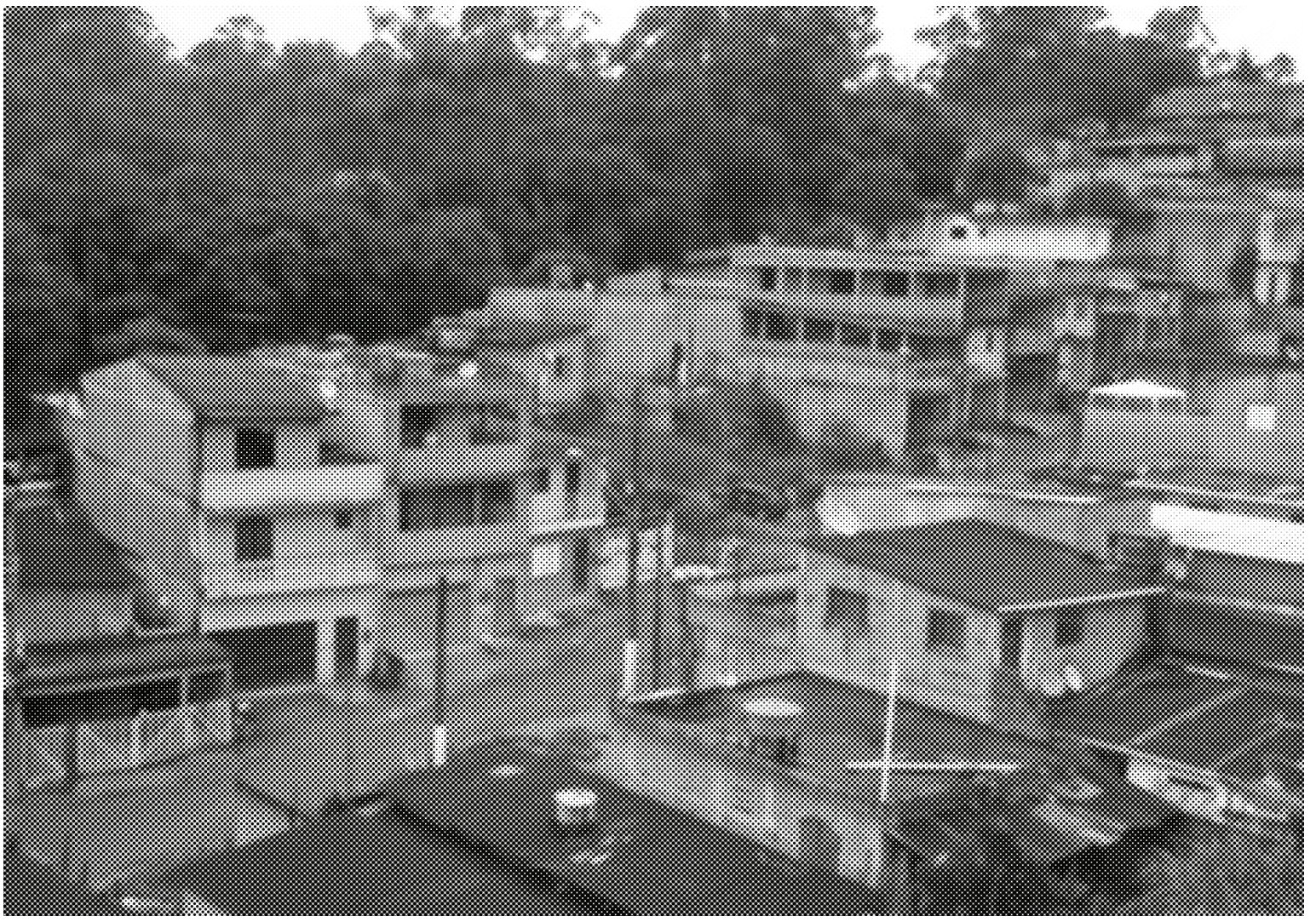

\section{1-2016 CAPELINHA E COCAIA, PEABIRU TCA, SÃO BERNARDO DO CAMPO - RMSP}

Na RMSP, a partir de 2009 (gestão PT) a prefeitura de São Bernardo do Campo destaca-se como uma das prefeituras que contratou maior número de projetos na área de habitação de interesse social, mais especificamente na atuação em assentamentos precários. Com uma equipe técnica capacitada e com experiência, a SEHAB PMSBC (Secretaria de Habitação da Prefeitura Municipal de São Bernardo do Campo) vai gerir processos, desenvolver projetos, acompanhar implementação de obras e acessar recursos, muitos deles oriundos dos programas federais. Neste quadro, a gestão municipal contrata a assessoria técnica Peabiru TCA para dois processos de urbanização de favelas do município.

A primeira experiência que aqui abordamos é o Capelinha-Cocaia. Dois assentamentos relativamente próximos, em área de mananciais, onde a premissa implicava, para além da melhoria urbana e regularização fundiária, a contenção da ocupação numa região de borda urbana e preservação ambiental.

Neste cenário, os técnicos da Peabiru procuram implementar algumas das técnicas que já vinham desenvolvendo nas suas experiências de urbanização de favelas. Reconhecendo a importância da decisão de quem fica ou quem sai nestes processos, a assessoria procurou desenvolver uma metodologia que, para além de garantir um conhecimento aprofundando sobre o território e as famílias que nele vivem, com uma pesquisa feita casa-a-casa, embasava tecnicamente a decisão sobre as possibilidades de remoção, de acordo com fig. 11 Vista Geral do

Capelinha, São Bernardo do Campo.

Fonte: cedida por Peabiru TCA.

50. Trata-se do IPHAB - Indice de Precariedade Habitacional, que abordaremos na Parte II. 


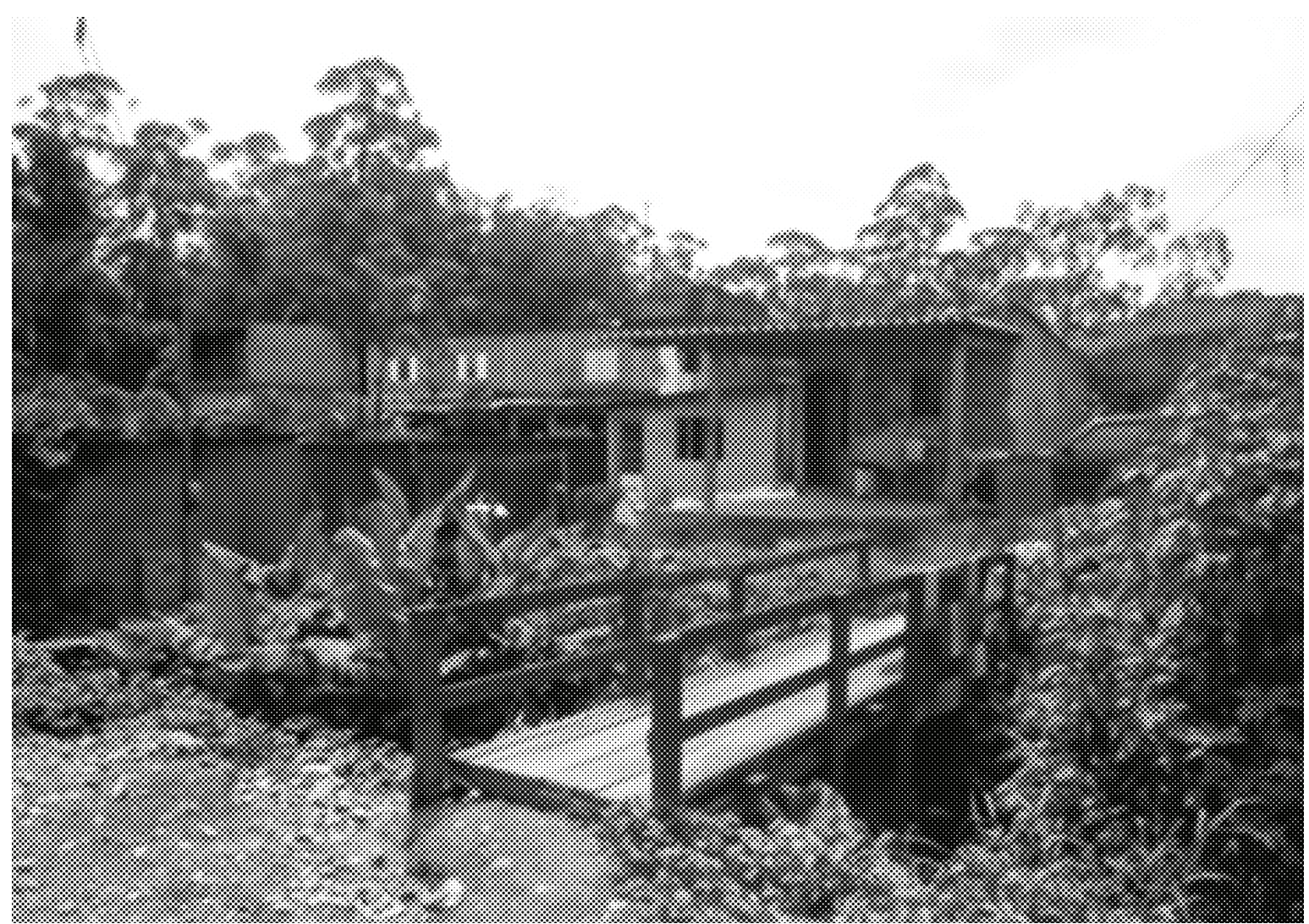

fig. 12 Capelinha e Cocaia, São Bernardo do Campo. Vista para áera de córrego com paisagem caracteristica de área de manancial. Fonte: cedida por Peabiru TCA.

5I. Entrevista realizada em I $7 /$ I I/20I5, São Paulo.

52. Idem

53. Idem o grau de precariedade da habitação, infraestrutura e estrutura social e familiar ${ }^{5 \circ}$. (SANTO AMORE e MARQUES, 20 I 5 , informação verbal ${ }^{51}$ )

A gestão pública permitiu e possibilitou a realocação das famílias dentro dos assentamentos, para as quais a Peabiru propôs tipologias horizontais, de casas sobrepostas, alocando-as nas bordas da intervenção, procurando conter e prevenir futuras ocupações. Preocupados com as condições de quem permaneceria nas suas casas autoconstruídas, mesmo que isso implicasse a consolidação de precariedades, a assessoria propôs a intervenção através de kits de melhorias habitacionais.

No entanto, com recursos derivados do PAC, a obra só foi contratada 3 anos depois. Para além das mudanças no território, físico e social, algo comum para qualquer área da cidade, mas potencializada pela informalidade destes territórios, foram necessárias adequações do projeto às técnicas disponibilizadas pela construtora contratada. A Prefeitura indicou a subcontratação da Peabiru (pela construtora) para a readequação de projeto. A revisão implicou algumas cedências das premissas inicias do projeto. Os técnicos da Peabiru consideraram que tal poderia ser evitado caso houvessem diálogos mais próximos, no tempo e no espaço, entre diagnóstico, projeto e obra, entre projetistas e construtoras (dentro da lógica da contração por empreitada) e que as projetistas já poderiam considerar as técnicas de construção disponíveis, viabilizando a celeridade do processo determinante nestes casos. (SANTO AMORE e MARQUES, 2015 , informação verbal ${ }^{52}$ )

A intervenção física no Cocaia foi concluída e a obra estava em desenvolvimento no Capelinha no final de 20 I 6. No caminho, foi reformulada a proposta de kits de melhorias habitacionais, dada a 


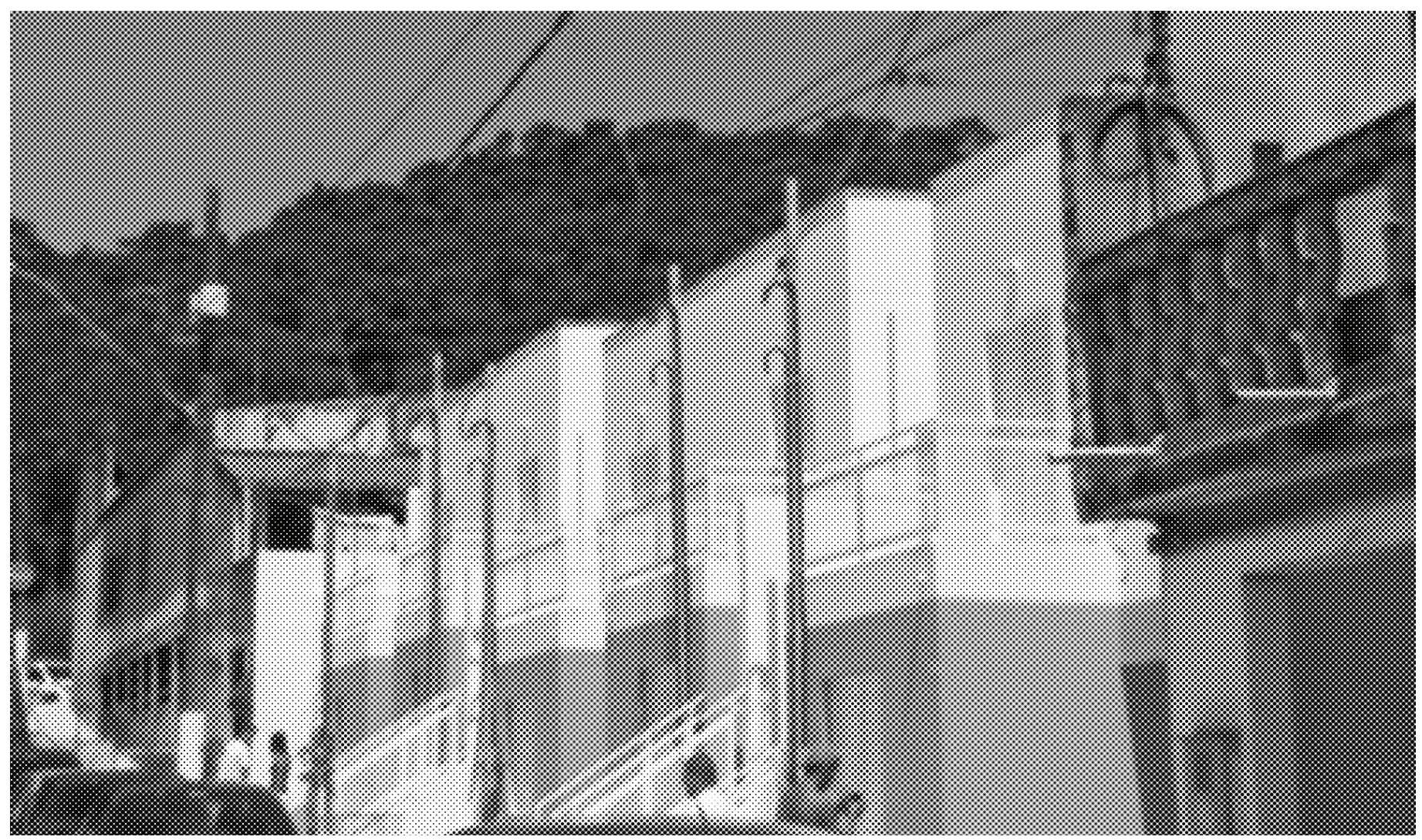

limitação de recursos financeiros, a qual a Peabiru acredita que até ao final da obra não será implementada, tanto pela limitação financeira, quanto pela dificuldade técnica da intervenção. A hipótese de intervenção através de ações minuciosas em moradias autoconstruídas ainda é, para uma grande empresa de construção, um sistema inadequado, para a qual a empresa não tem o perfil técnico necessário nem o interesse de implementar. $\mathrm{Na}$ voz dos arquitetos da Peabiru, esta ainda é uma parte a intervenção em favelas que precisamos explorar e transformar se pretendemos avançar no sentido da assessoria ao ambiente autoconstruído, o que no caso do Brasil, é um grande desafio. (SANTO AMORE e MARQUES, 20 I 5 , informação verbal ${ }^{53}$ ) fig. 13 Cocaia, São Bernardo do Campo. Unidades Habitacio-

nais sobrepostas, na inauguração.

Fonte: cedida por Peabiru TCA. 


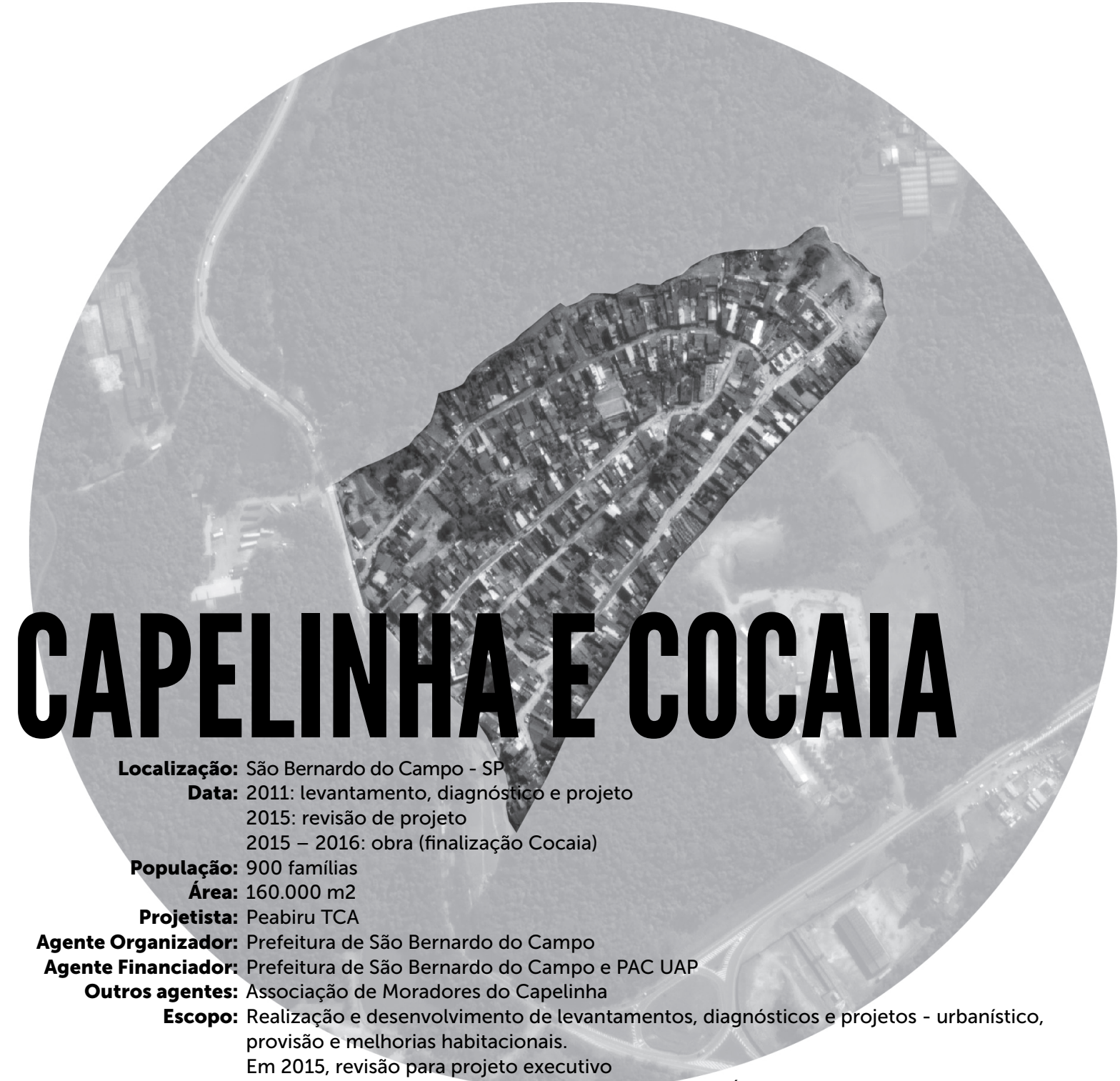

Breve descrição: Núcleos habitacionais localizados na APRM-Billings (Área de Proteção Região dos Mananciais da Represa Billings), em São Bernardo do Campo. Os núcleos se caracterizam por um conformação de média densidade, com características próximas das rurais. A Peabiru fez os projetos de urbanização e infraestrutura, estruturando o sistema viário a partir da melhoria e ampliação das vias existentes e prevendo um parque linear que ocupa as margens dos córregos recuperados. Grande parte das moradias foi consolidada e foram criadas novas tipologias sobrepostas para as famílias removidas, que permanecerão integralmente nos dois núcleos. Foi feito também um levantamento das moradias que resultou em pacotes específicos de melhorias para unidades consolidadas. Procurou-se um processo participativo através de assembleias para consulta e acompanhamento do projeto por parte da população atingida.

Atividades realizadas: Levantamentos, diagnóstico - aplicação do IPHAB;

projetos básicos e executivos, urbanístico, complementares e de arquitetura das unidades habitacionais; obra completa no Cocaia; obra em implementação no Capelinha.

Observações: Depois de licitada a obra, e dadas as transformações dos núcleos entre 2011 e 2015, a PMSBC indicou que a construtora contratasse a Peabiru para a revisão do projeto básico e realização de projeto executivo. Houve uma consequente diminuição de casas a serem removidas, pois não eram mais precárias, e foi desenhado um novo projeto de implantação, e seus projetos complementares, para além da adequação das tipologias habitacionais.

Na limitação orçamentária, não há garantia de implementação dos projetos de melhorias habitacionais. 


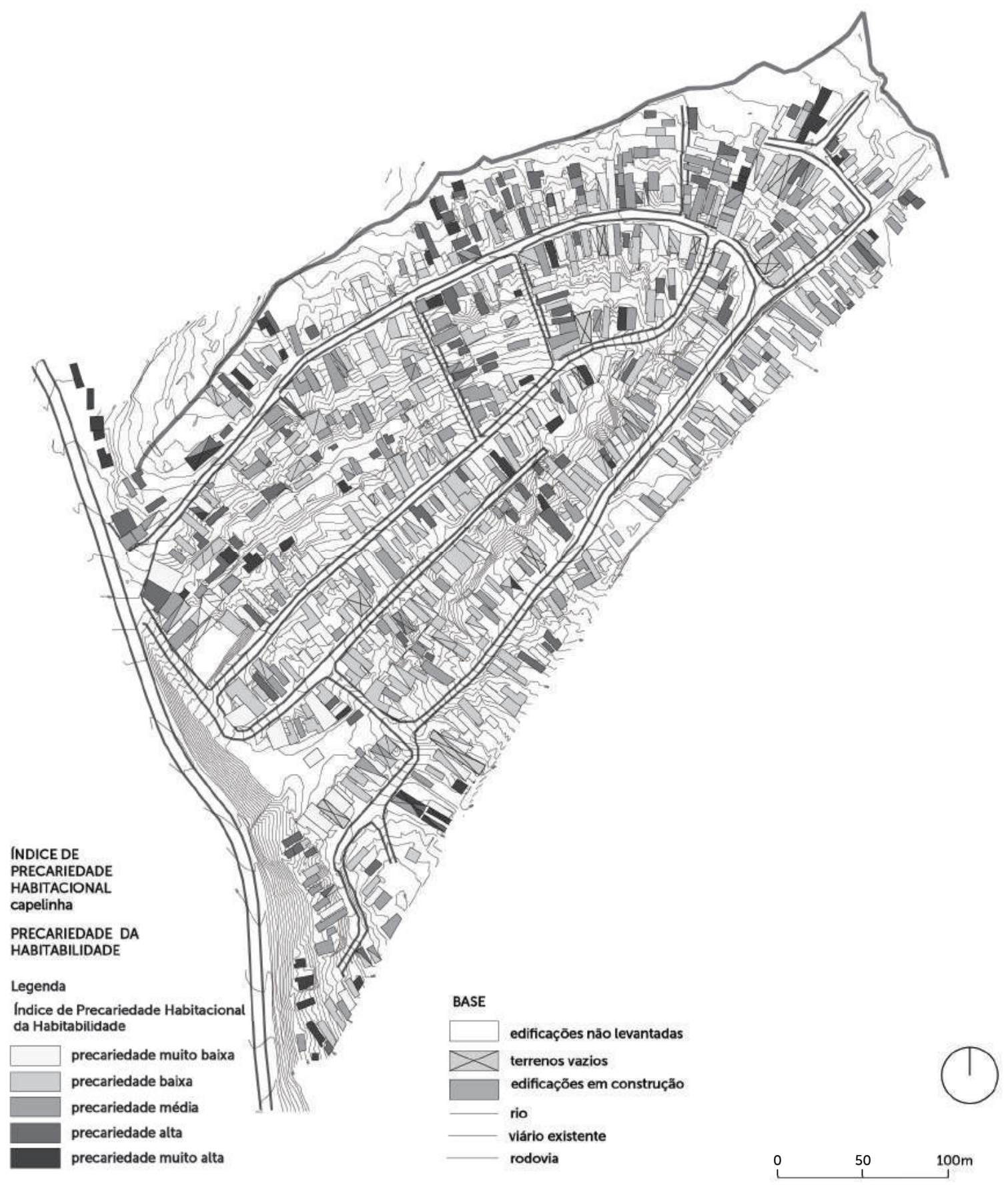

\section{Síntese de Levantamento e Diagnóstico do Capelinha}

Desenho elaborado a partir de desenhos disponibilizados por Peabiru TCA. O desenho é parte do IPHAB - Índice de Precariedade Habitacional, desenvolvido pela Peabiru e aplicado ao Capelinha. No desenho aparece a representação de precariedades por unidade habitacional, o que para a assessoria, indica diretrizes de projeto.

Elaboração: Bárbara Muhle sob coordenação da autora

Fonte base: cedida por Peabiru TCA

(página anterior: Destaque da favela Capelinha, São Bernardo do Campo, sobre fotografia aérea atual, Google Earth, 2016. Elaboração: Bárbara Muhle sob coordenação da autora) 


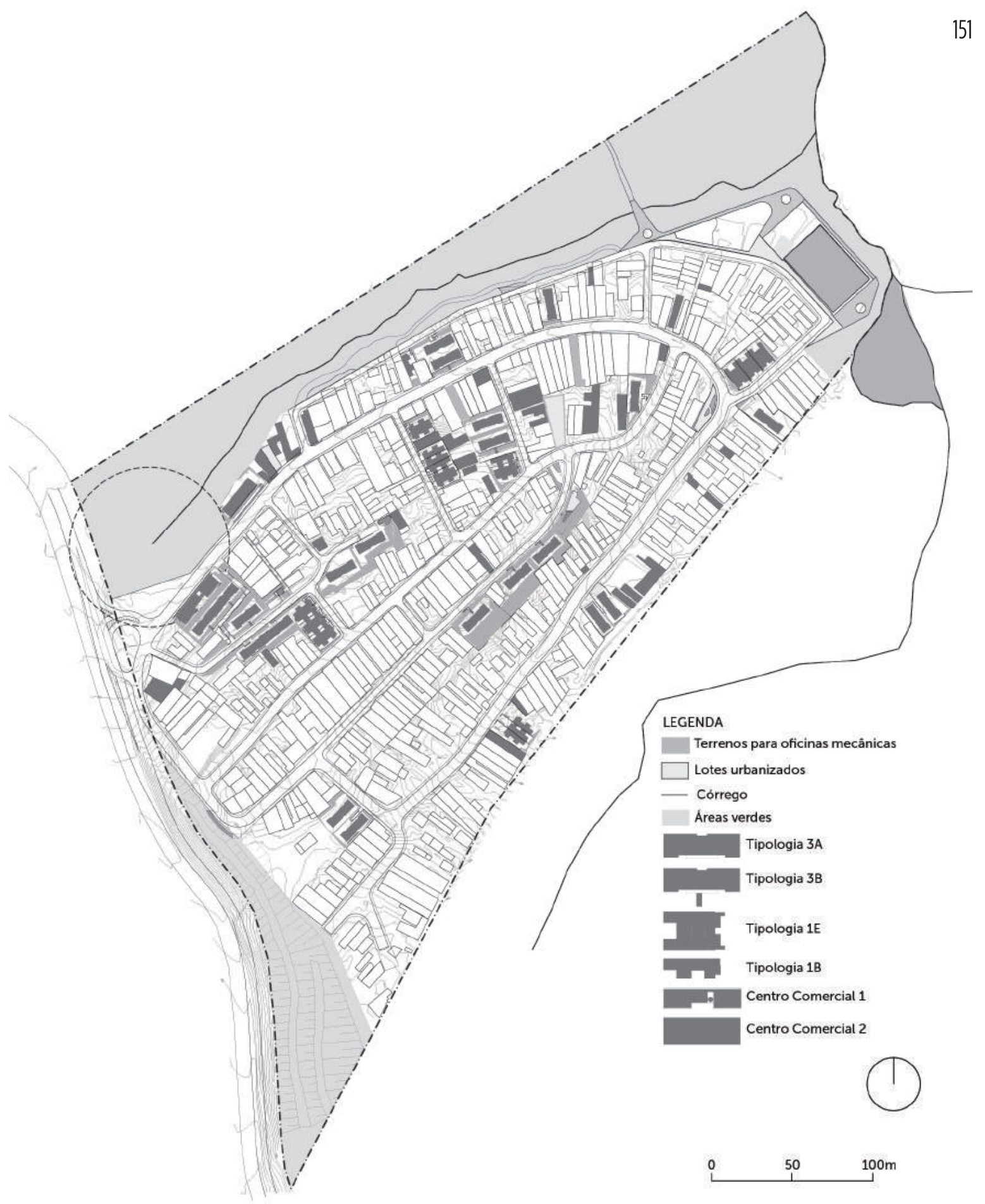

\section{Síntese do Projeto de Intervenção do Capelinha}

Desenho elaborado a partir de desenhos disponibilizados por Peabiru TCA. No desenho aparecem as propostas de intervenção da Peabiru, onde se destacam as novas unidades habitacionais e a proposta de contenção das bermas da favela para proteção ambiental e de risco. Para a implementação da obra houve revisão e readaptação do projeto realizadas pela Peabiru

Elaboração: Bárbara Muhle sob coordenação da autora

Fonte base: cedida por Peabiru TCA 


\section{4-2016 BATISTINI, PEABIRU TCA, SÃ0 BERNARDO DO CAMPO - RMSP}

\author{
Em 20 I 4, a SEHAB de São Bernardo
}

do Campo contratou novamente a Peabiru, desta vez para o desenvolvimento de projeto do Batistini. O Batistini é um assentamento precário informal, com características semelhantes a um loteamento irregular, lotes e ruas ortogonais, mas com algumas áreas com um grande grau de precariedade.

Mais uma vez a Peabiru procurou aplicar os conceitos e metodologias que já vinham desenvolvendo. No caso do Batistini a gestão municipal cedeu ainda mais autonomia à assessoria o que possibilitou que a equipe pensasse e implementasse o processo de uma forma global: levantamento, diagnóstico, plano, intervenção, reassentamento e melhorias habitacionais. O IPHAB - Índice de Precariedade Habitacional ${ }^{54}$, por exemplo, foi aplicado pensando na sua utilidade como recurso para tirar dúvidas durante a elaboração do projeto, mas também como base para a definição do programa de melhorias habitacionais. Para o processo participativo a Peabiru realizou algumas oficinas ${ }^{55}$ para diferentes grupos de moradores que privilegiaram o compartilhamento das práticas utilizadas pelos técnicos para a sua apreensão pela comunidade. A assessoria teve também autonomia para aplicação do sistema de selagem desenvolvido pela própria equipe, através de placas pré-moldadas e com a mesma numeração aplicada nos questionários, o que o Peabiru considera um sistema mais digno do que a selagem habitualmente feita pelos organismos públicos em casos semelhantes. ${ }^{.6}$
(SANTO AMORE e MARQUES, 20 I 5 , informação verbal ${ }^{57}$ )

Tanto a gestão pública quanto os projetistas reconheciam a complexidade da ação e a necessidade de uma atuação multisectorial integrada, por isso, a Peabiru também ficou responsável pela gestão de todos os restantes levantamentos técnicos e projetos complementares o que possibilitou uma melhor adequação dessas práticas à necessidade dos projetistas da arquitetura e urbanismo.

As propostas de reassentamento e realocação, na mesma área ou em área contígua ao Batisitini, ou de melhorias habitacionais para moradias a consolidar, procuraram atender à variedade de necessidades da população. Exemplo disso é a proposta de uma casa evolutiva a ser construída como substituição do caso de habitações individuais muito precárias.

No caso, ainda não concluído, uma das maiores críticas da Peabiru foi na demora da aprovação ambiental que atrasou todo o processo. Os entraves ambientais colocados, implicaram a alteração de algumas premissas iniciais (área e projeto de reassentamento). A demora pode também implicar a descontinuidade do processo e a possibilidade de que a obra não seja construída pois no começo de 20 I 7 uma nova gestão entrou na prefeitura, o que pode implicar novas diretrizes políticas, inclusive o abandono deste e de outros processos de urbanização de favelas. (SANTO AMORE e MARQUES, 20 I 5 , informação verbal $5^{8}$ )

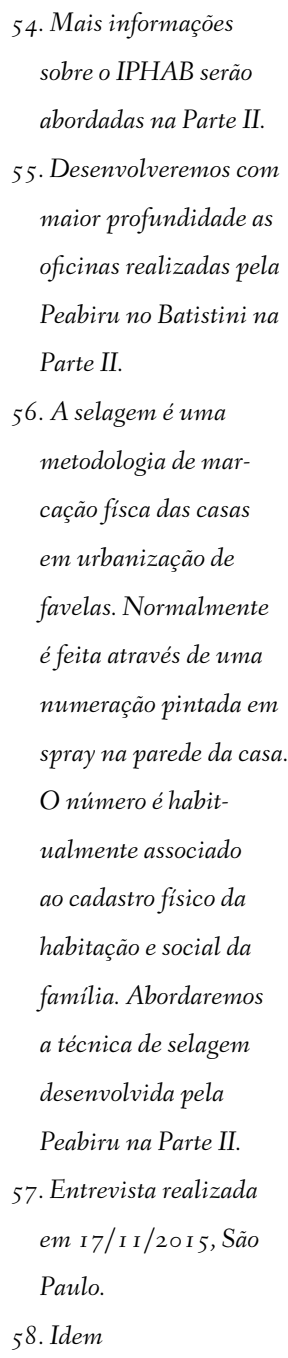




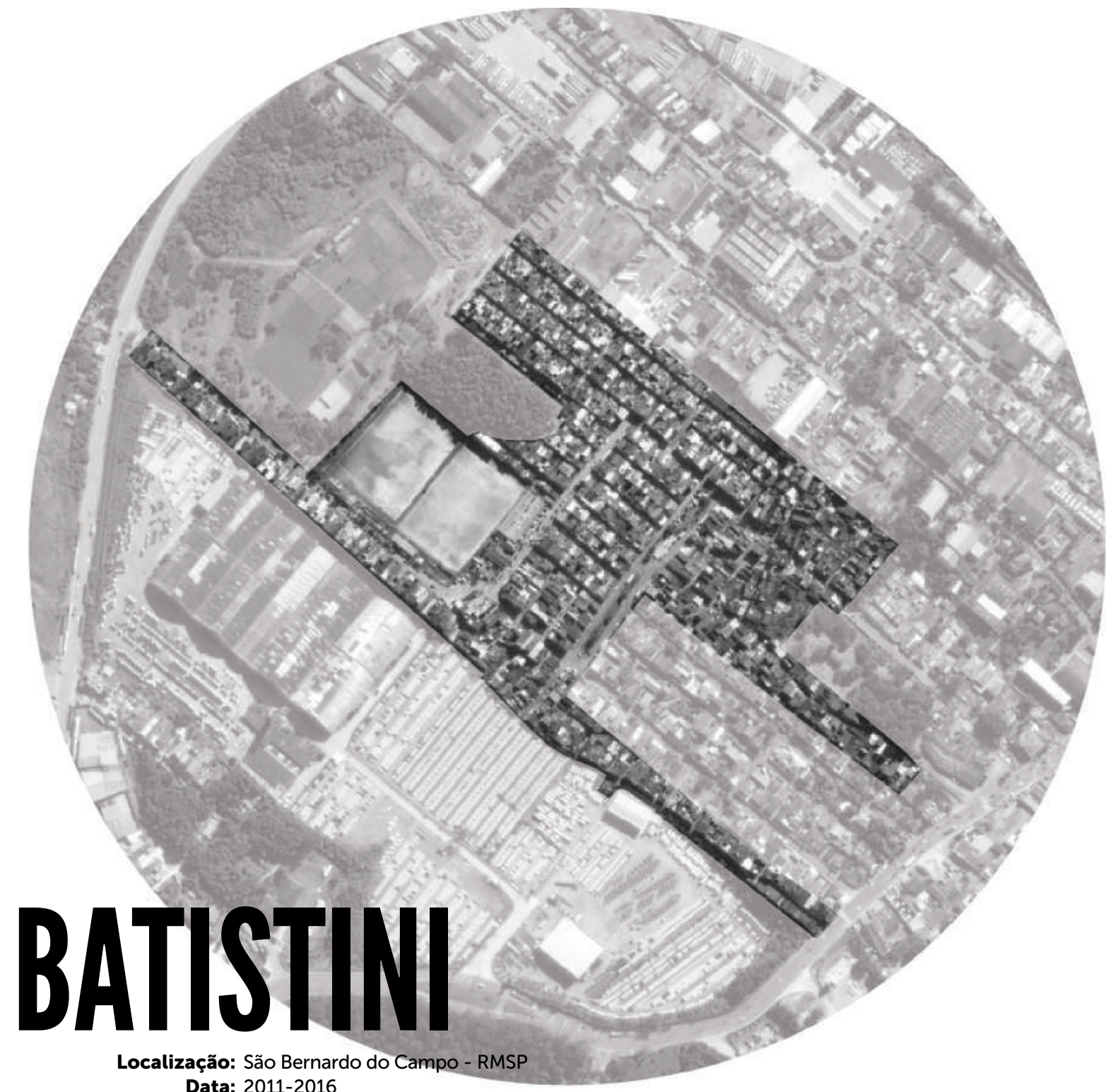

Data: 2011-2016

População: 1686 famílias

Área: $189.500 \mathrm{~m} 2$

Projetista: Peabiru TCA

Agente Organizador: Secretaria de Habitação - SEHAB, Prefeitura Municipal de São Bernardo do Campo PMSBC Agente Financiador: PMSBC, PAC UAP - PAC2, MCMV2

Outros agentes: Associação de Moradores

Escopo: Elaboração e coordenação de levantamento urbanístico e social, selagem, diagnóstico integrado, projetos básicos completos de edificações e infraestrutura pública em assentamento precário a ser consolidado e urbanizado. Projeto de arquitetura de equipamentos e HIS. Projeto de melhorias habitacionais.

Breve descrição: Na área de urbanização foram previstas unidades de moradia evolutivas. Para aquelas a serem consolidadas foram pensados projetos de melhoria habitacional, através de kits. Foram previstas novas praças e áreas de lazer em áreas de ocupação desordenada e precária, e a Associação de Moradores será transferida para um novo edifício. Em terreno livre contíguo ao assentamento serão previstas 664 novas unidades que atenderão famílias do Batistini e de outras áreas de manancial.

Atividades realizadas: Processo participativo (Oficinas, Assembleias, atendimento individualizado), levantamentos, diagnósticos, projetos e revisões

Observações: O processo embateu na aprovação ambiental afeta a uma das áreas da intervenção. A Peabiru reviu o projeto adequando às novas diretrizes. O processo está neste momento estagnado. 


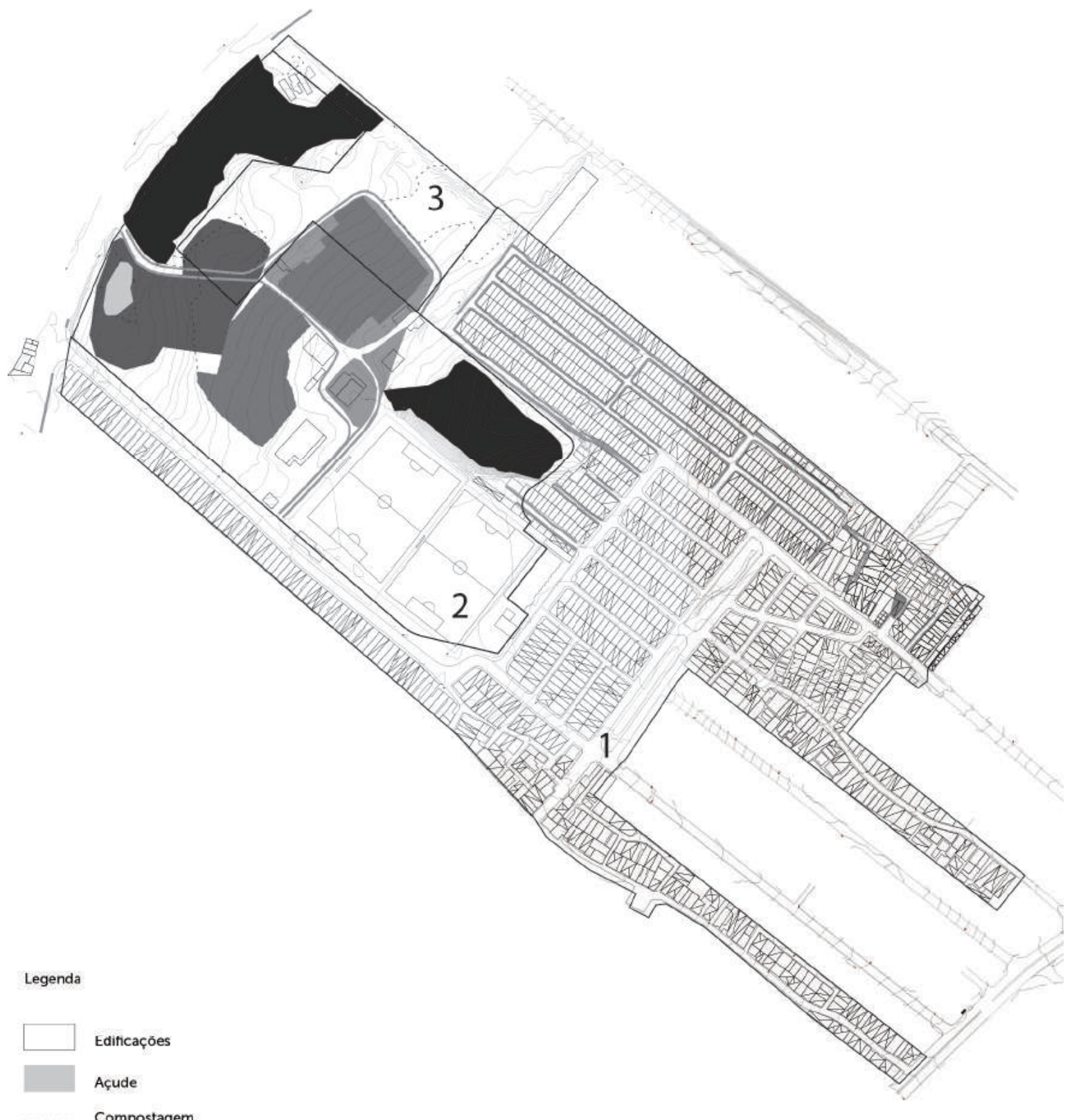

Compostagem

Horta Existente

Solo Mole

Rua de Terra

1 - Assentamento

2 - Area para reassentamento

3- Associaçăo Santo Inácio

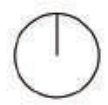

Mata

\section{do Batistini \\ Síntese de Levantamento do Batistini}

Desenho elaborado a partir de desenhos disponibilizados por Peabiru TCA. No desenho de levantamento identificam-se as diferentes áreas passíveis de intervenção. Também para o Batistini foi realizado o IPHAB tal como no Capelinha, índice que ajudou na definição da remoção de moradias por precariedade e no projeto de melhorias habitacionais.

Elaboração: Bárbara Muhle sob coordenação da autora

Fonte base: cedida por Peabiru TCA

(página anterior: Destaque da favela Batistini, São Bernardo do Campo, sobre fotografia aérea atual, Google Earth, 2016.

Elaboração: Bárbara Muhle sob coordenação da autora) 


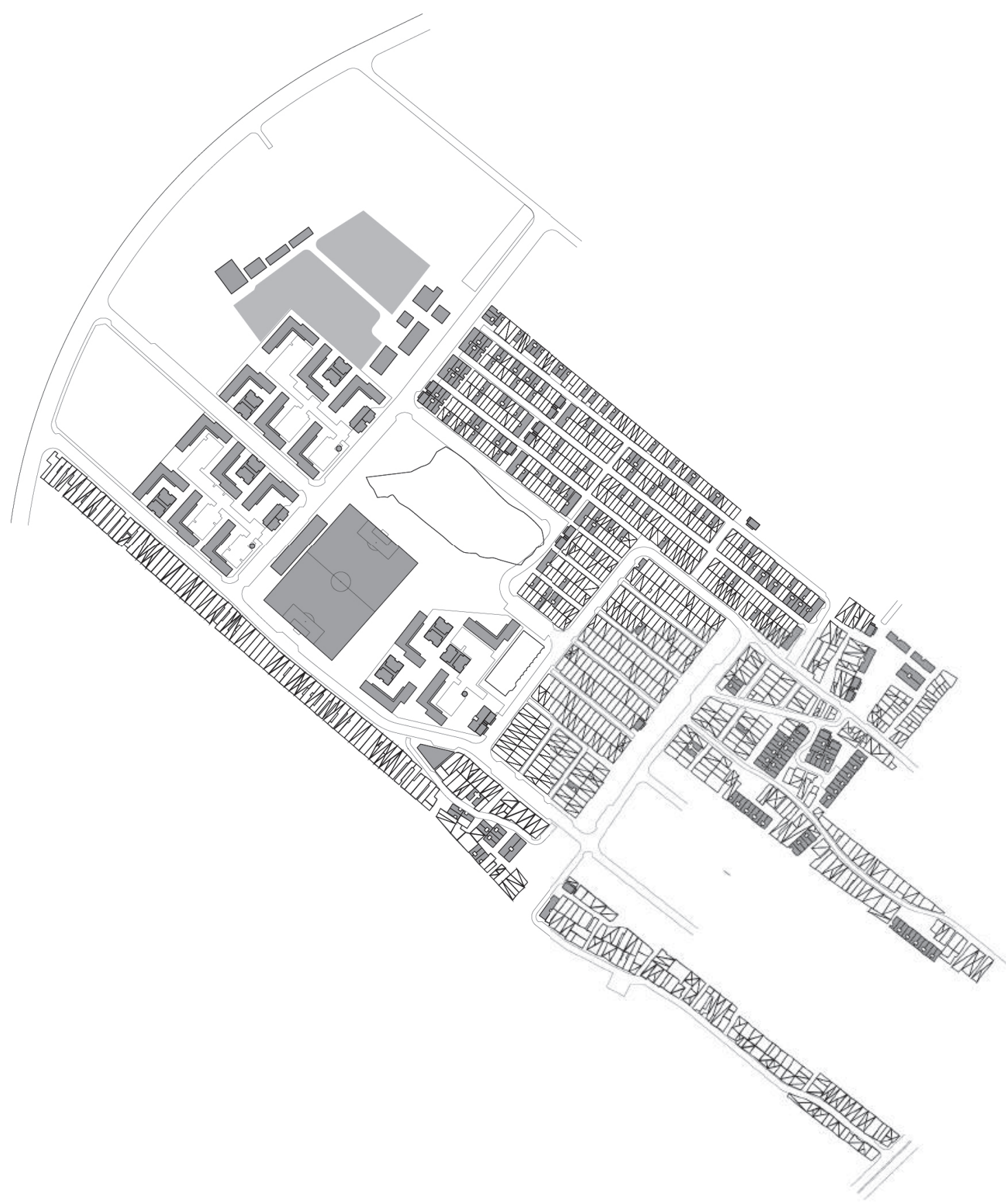

\section{Legenda}

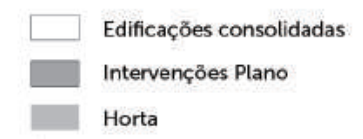

Proposta Usos Santo Inácio

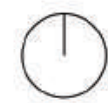

$0 \quad 50 \mathrm{~m}$

\section{Síntese do Projeto de Intervenção do Batistini}

Desenho elaborado a partir de desenhos disponibilizados por Peabiru TCA. No desenho destacam-se os projetos de provisão habitacional, notam-se a proposta de substituição de novas unidades dentro dos lotes existentes. Na necessidade de remoção de algumas famílias, por precariedade, abertura de vias, entre outros, há a sugestão de construção de novos edifícios habitacionais em terreno contíguo disponível, e que poderão ainda assentar famílias removidas de outros territórios. Elaboração: Bárbara Muhle sob coordenação da autora 


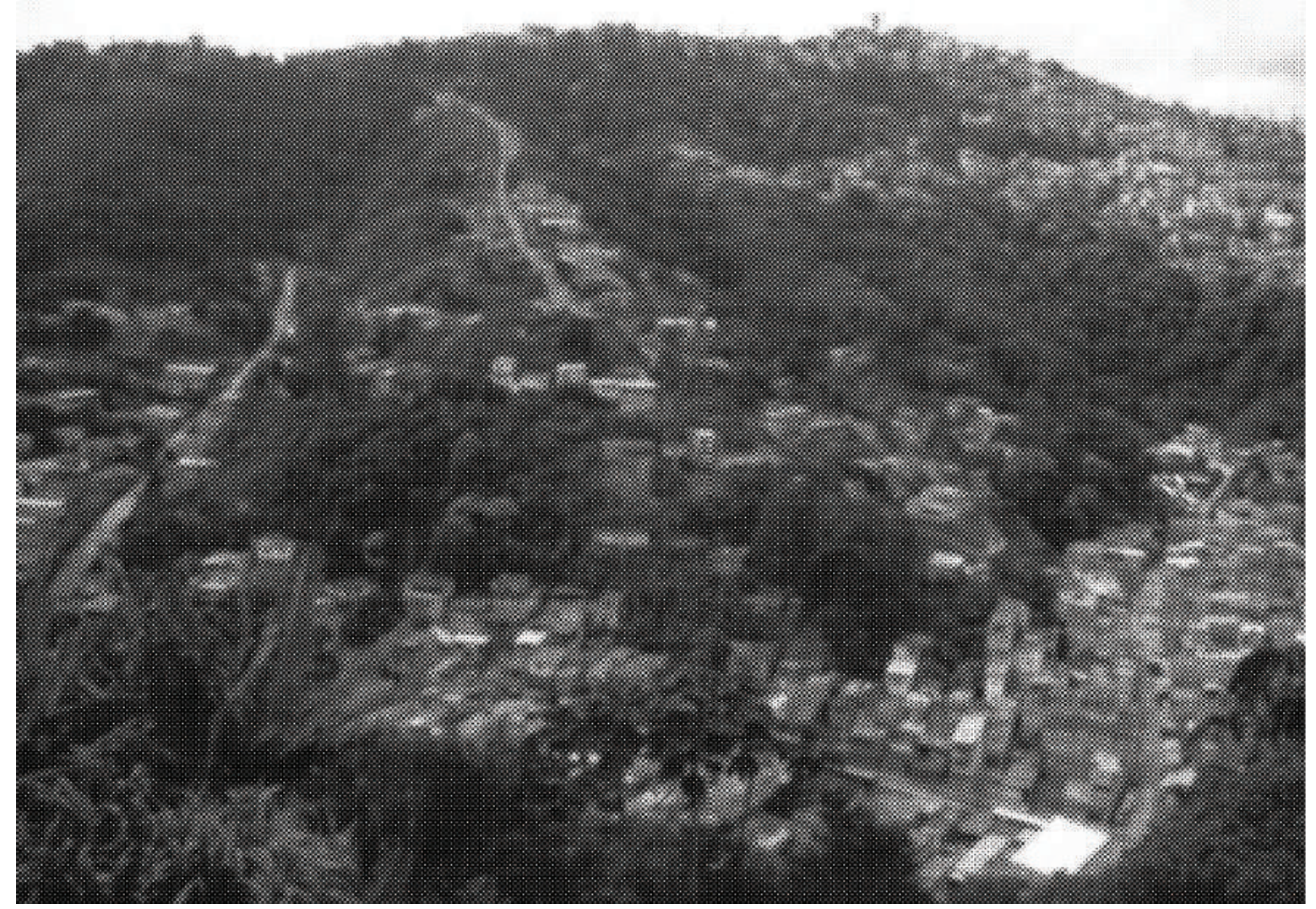

\section{3-(...) COMPLEXO CHAFIK-MACUCO, SECRETARIA DE OBRAS MAUÁ E TEREZA ARQUITETURA, MAUÁ - RMSP}

Em 20 I 3 o arquiteto Milton Nakamura foi convidado para assumir o cargo de Secretário Adjunto na Secretaria de Obras da Prefeitura de Mauá, um dos municípios mais pobres da RMSP. Assumindo este compromisso, e recorrendo à sua experiência de intervenções em favelas ${ }^{59}$, procurou viabilizar um processo de Urbanização de Assentamentos Precários, através do financiamento federal PAC UAP.

O assentamento é o Complexo Chafik-Macuco, o maior assentamento precário do Município, situado em região de borda urbana, do limite de área florestal. Para enfretamento da possibilidade de urbanização, o complexo foi dividido por setores e foram identificadas suas prioridades, designado como áreas prioritárias de intervenção, os setores I, 2, 3 e 4 .
Á semelhança das experiências já protagonizadas por Heloisa Rezende em Taboão da Serra, e do próprio Milton em Diadema, este trata-se de um caso onde o relato de militantes se dá no papel de gestor público. Consideramo-la dentro deste quadro por ilustrar um acúmulo de conhecimento de um arquiteto, também projetista, e por compreendermos que este currículo profissional ambivalente possibilitou explorações e contribuições para o conhecimento técnico sobre Urbanização de Favelas para os projetistas militantes.

Como gestor público, Milton viabilizou diálogos intersetoriais e entre secretarias, que dificilmente existem dentro das gestões públicas, no sentido de partilhar a questão com os restantes gestores, e facilitar a resolução de problemas que pudessem surgir no processo. Para além disso, e reconhecendo
59. Ver Currículo de

Milton Nakamura em Parte I, Capitulo o I.

6o. Encontro do GE_Favelas em 05/10/2015, São Paulo.

6. Sobre o diagnóstico e a proposta de melhorias habitacionais proposta, ver Parte II.

62. Encontro do GE_Favelas em 05/10/2015, São Paulo.

63. Entrevista realizada em I 4/I 2/2OI 5, São Paulo. 64. Idem. 


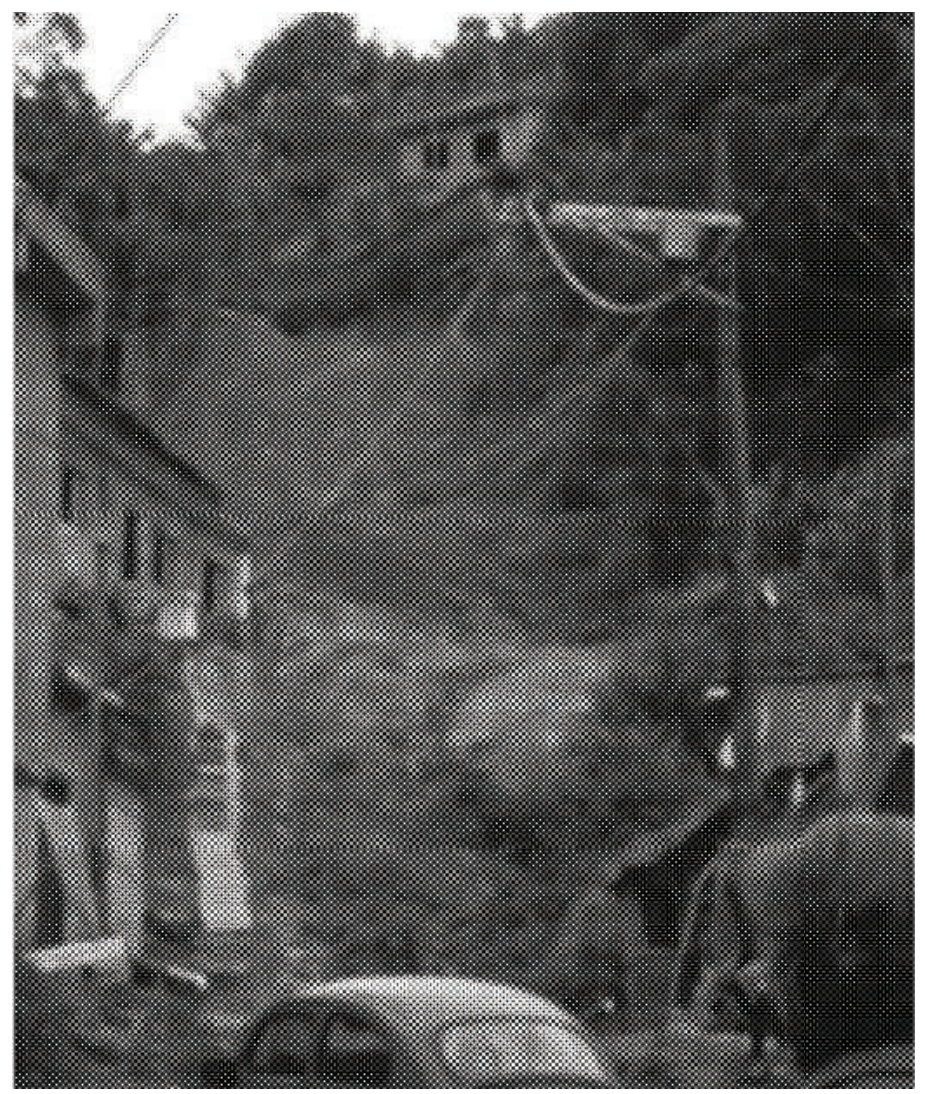

fig. 15 Chafik-Macuco., Mauá. A imagem representa a complexidade morfológica, ambiental e

geológica do assentamento.

Fonte: cedida por Milton Nakamura.

65. As autoras desta pesquisa entendemo cenário colocado como um reflexo, não apenas de uma crise econômica, mas de um discurso politico conservador criado em torno do mesmo, que embason os recentes acontecimentos politicos como o Golpe Parlamentar à Presidenta eleita democraticamente, e avançam no sentido dos cortes de investimentos públicos afetando todos os quadros da sociedade, sobretudo os mais carentes. as questões ambientais e a sua importância para aquele território, contratou consultorias qualificadas de geotécnicos e biólogos, e atualizou a carta dos cursos de água, prevendo a possibilidade de surgirem entraves ambientais relacionados. Este diagnóstico prévio foi fundamental para a definição das diretrizes fundamentais que orientaram projeto. (NAKAMURA e LUPO 20 I 5 , informação verbal ${ }^{60}$ )

Para o desenvolvimento do trabalho foi contratado um escritório de arquitetura TEREZA Arquitetos, também com reconhecida competência técnica para a intervenção em favelas. Foi incluído no projeto um diagnóstico demonstrativo e a proposta para a intervenção de melhorias habitacionais ${ }^{61}$. Também a proposta de reassentamento levou em consideração a ocupação e a morfologia do terreno, com um projeto de edifícios sobrepostos que vão se desenvolvendo num sistema de adequação à encosta, possibilitando a ocupação de terrenos com declividade acentuada, mas também facilitando a sua contenção geotécnica. (NAKAMURA e LUPO 20 I 5 , informação verbal ${ }^{62}$ )

Uma das ações que melhor demonstram o seu interesse pelas questões sociais e o comprometimento com melhor desenvolvimento do processo foi a mobilização de uma ação conjunta entre equipe física e equipe social da prefeitura. Para além de trabalharem juntas na viabilização do projeto, estiveram permanentemente presentes em campo, fomentando um diálogo com a população, demonstrando uma representação ativa do poder público, e atualizando 


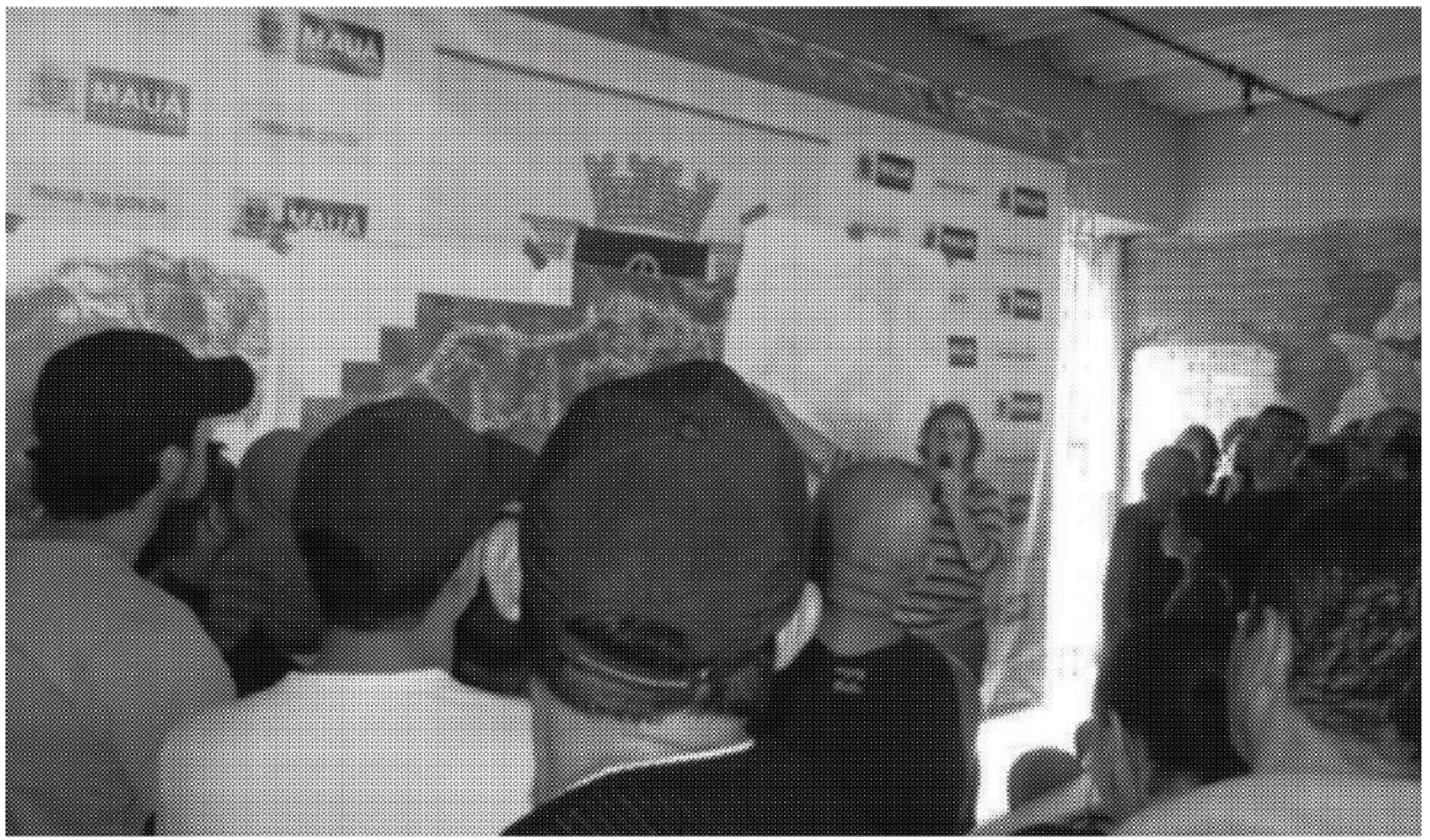

constantemente os dados relativos aos diagnósticos físicos e sociais, o que possibilitou a melhor adequação possível do projeto aos seus destinatários, sujeitos e território. (NAKAMURA, 20 I 5 , informação verbal ${ }^{63}$ )

Apesar desta disponibilidade e vontade política, o processo foi obrigado a seguir os prazos impostos pelo programa público federal PAC, que em muitos casos não são os prazos adequados ao tempo do processo de urbanização de favelas. (NAKAMURA, 2015 , informação verbal ${ }^{64}$ )

Em 20 I 6 o processo de viabilização de urbanização do Chafik-Macuco arrefeceu pois Milton assumiu um cargo em outra Prefeitura deixando a gestão de Mauá. Com isso verificamos que os processos estão muito atrelados aos indivíduos e às vontades políticas de sujeitos ou de gestões, o que pode facilitar ou dificultar o processo no sentido militante que aqui exploramos.

Para além da influência das mudanças dos quadros técnicos, também os recursos financeiros, viabilizam ou dificultam as intervenções. Apesar das dificuldades e imposições colocadas pelo PAC, a sua existência permitiu a intervenção em diversas regiões do país como colocado por Petrarolli (20 I 5 ) e Moretti et al. (20 I 5). No presente clima de instabilidade política, e retrocesso dos investimentos públicos, desconhece-se se os processos em curso, sobretudo os que estão na situação do Batistini e Chafik-Macuco, ainda sem obra, terão a mesma disponibilidade de investimentos direcionados nos próximos anos, permitindo a sua continuidade e concretização. ${ }^{65}$ fig. 16 Apresentação de projeto para a população, feita po Renata Moreira (TEREZA Arquitetura) Chafik-Macuco., Mauá.

Fonte: cedida por Milton Nakamura. 


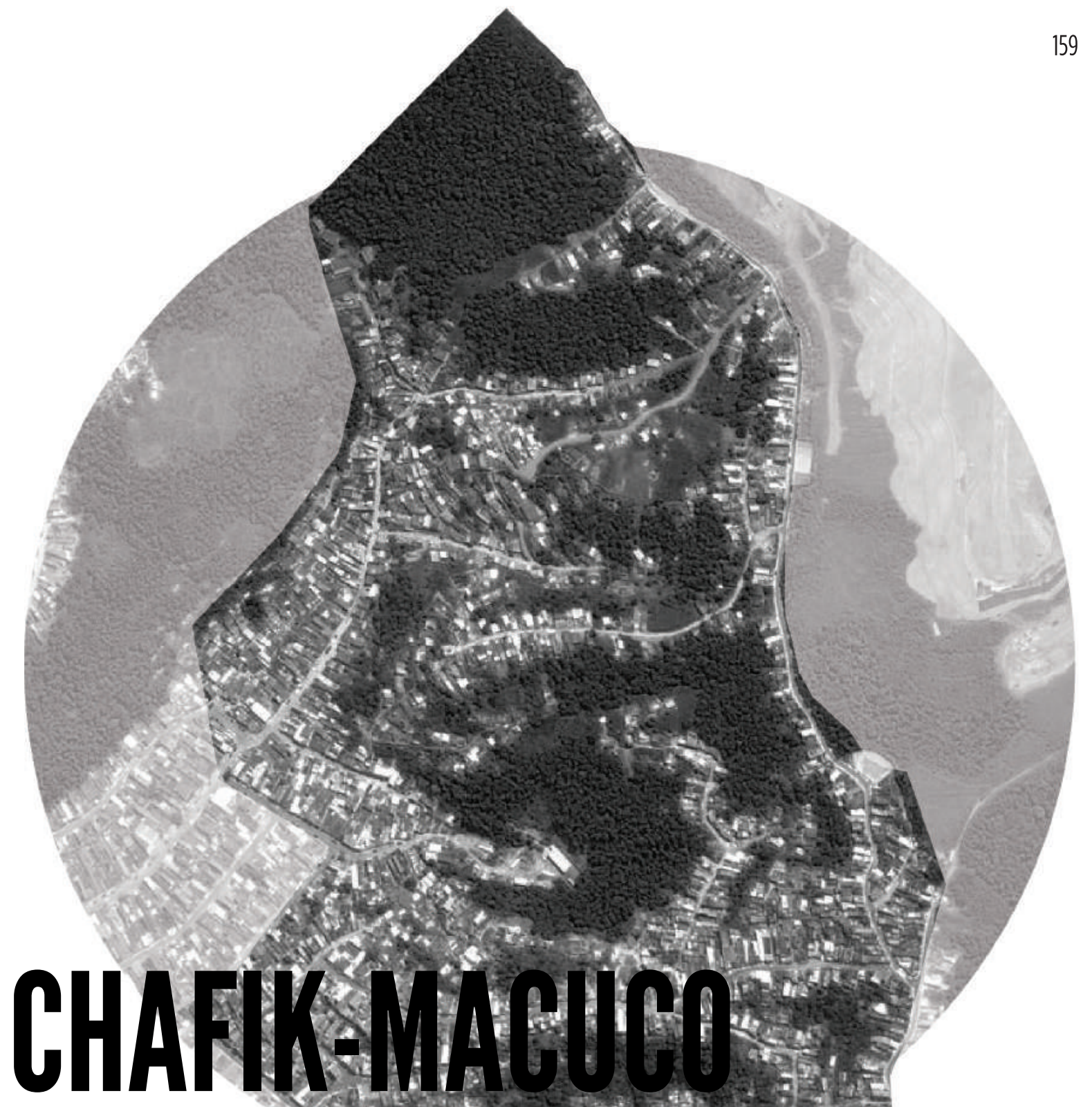

Localização: Mauá - RMSP

Data: 2013-

População: 2.700 domicílios

Área: $556.854 \mathrm{~m} 2$

Projetista: TEREZA arquitetura e urbanismo

Agente Organizador: Secretarias de Obras, Habitação, Trabalho Social e Regularização Fundiária da Prefeitura Municipal de Mauá - PMM

Agente Financiador: PMM e PAC UAP - PAC 2

Escopo: Levantamento, diagnóstico, projetos urbanísticos, de remoção e realocação de famílias, de edificações e de melhorias habitacionais

Breve descrição: Projeto de intervenção sobre parte do assentamento Chafik-Macuco, na designada área prioritária, contemplando os setores 1, 2, 3 e 4. A intervenção tem como diretriz e finalidade a promoção dos sistemas de serviços urbanos a todos os moradores do assentamento objeto de intervenção: desde os sistemas de infraestrutura e equipamentos urbanos, que garantem acessibilidade e salubridade, incluindo o sistema fundiário, com regularização e titulação da propriedade, bem como a implementação de medidas necessárias para garantir a melhoria das condições de habitabilidade das unidades, com garantia de permanência dos atuais moradores.

Atividades realizadas: Levantamentos, diagnósticos e projetos

Observações : Milton Nakamura foi responsável pela coordenação do projeto enquanto secretário adjunto da Secretaria de Obras de Mauá. No final de 2015, deixou de acompanhar o processo por ter passado a integrar a equipe técnica da Secretaria de Habitação de São Paulo.

No começo de 2017, o projeto recebeu aprovação par implementação subsidiado pelo PAC-2. 


\section{Síntese de Levantamento do Chafik-Macuco}

Desenho elaborado a partir de desenhos disponibilizados por

TEREZA Arquitetura. No desenho é evidente a grande dimensão

da favela e sua relação com área limite de ocupação urbana.

Elaboração: Bárbara Muhle e Beatriz Nobumoto sob coordenação da autora

Fonte base: cedida por TEREZA Arquitetura (página anterior: Destaque da favela Chafik-Macuco, Mauá, sobre fotografia aérea atual, Google Earth, 2016. Elaboração: Bárbara Muhle sob coordenação da autora)

Legenda Areas Livres Corpo d'água Preservação Recuperaçăo Recreaçåo

Circulaçăo de pedestres - A.E.I,S

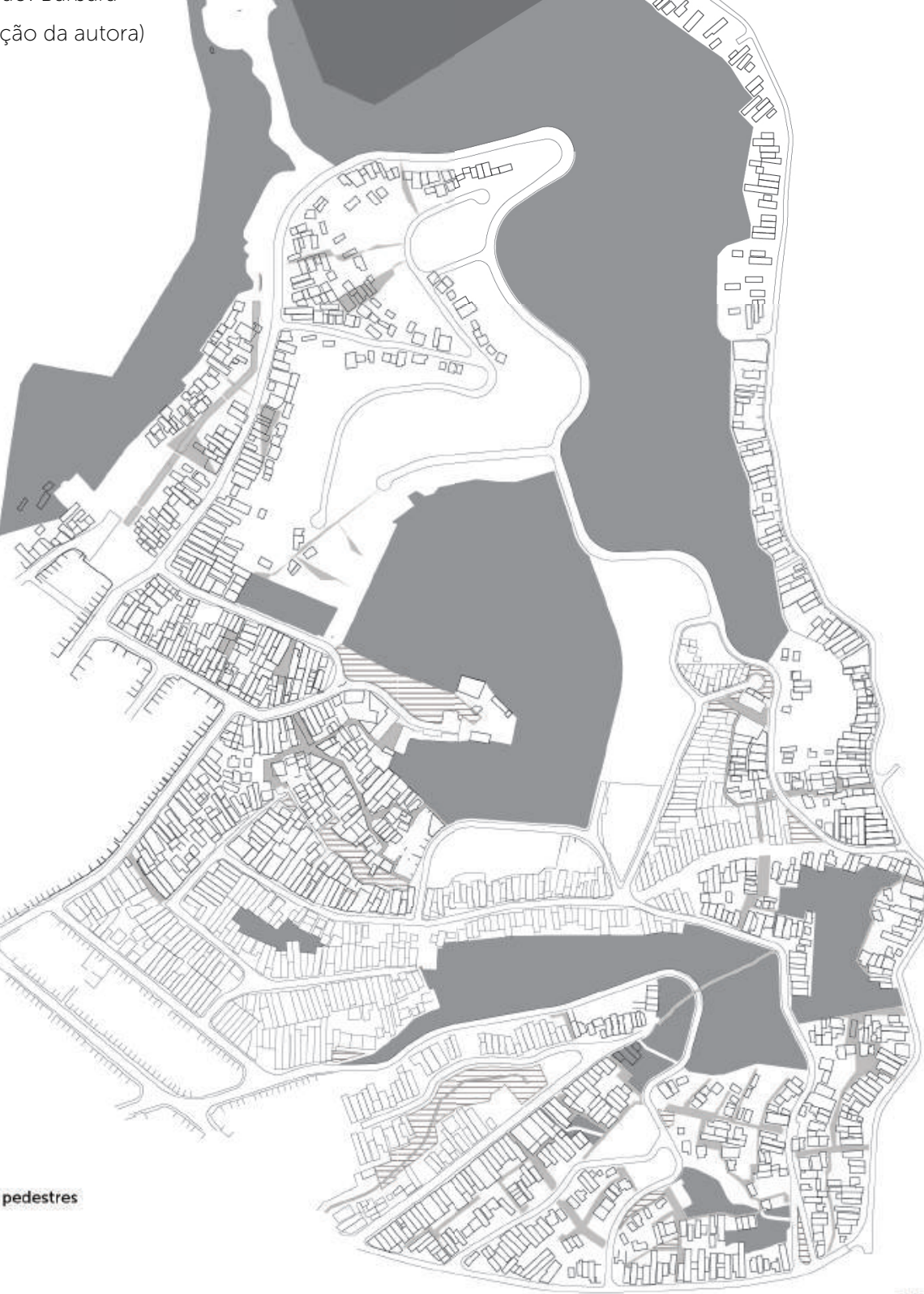




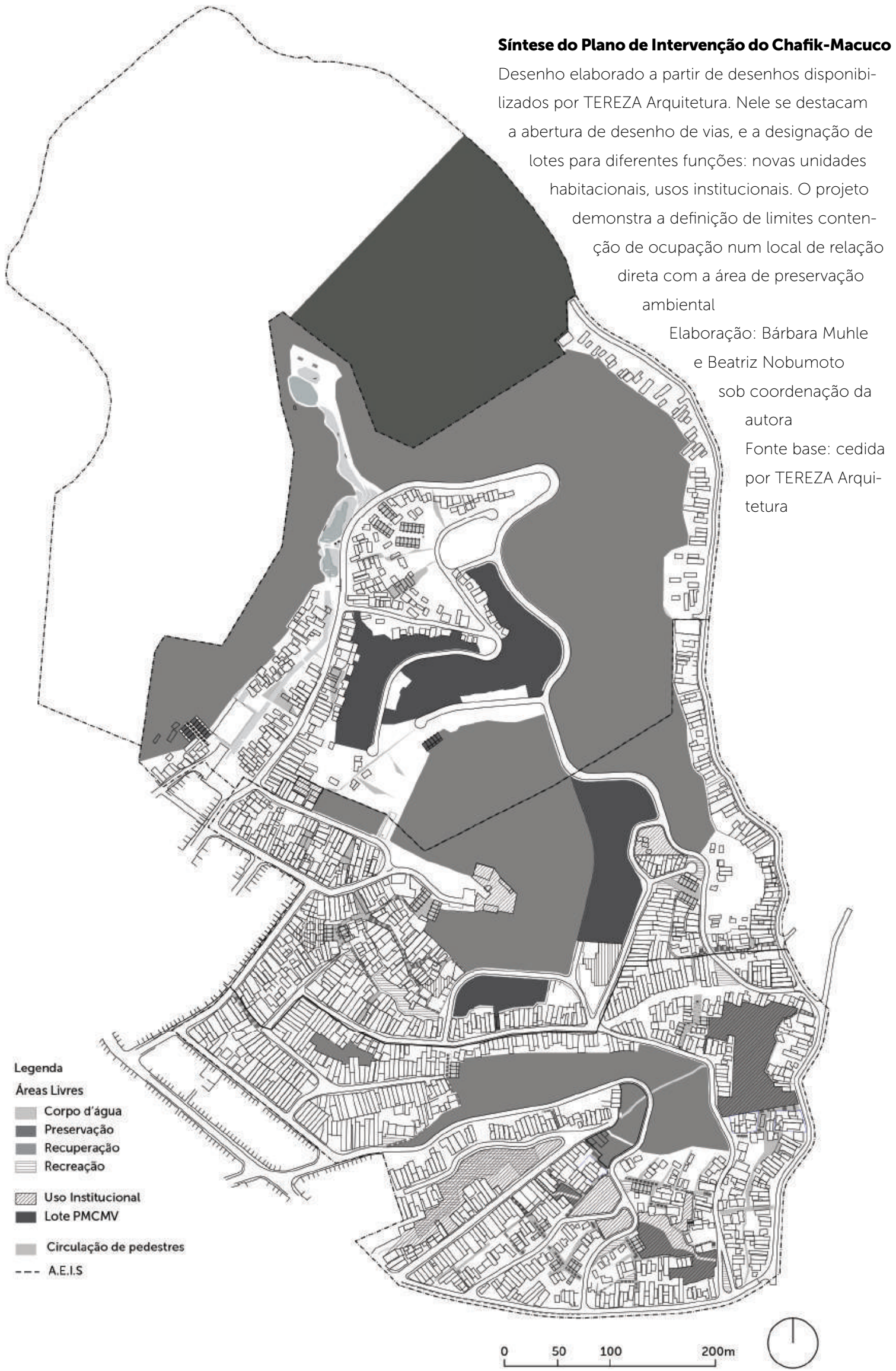


As experiências que aqui apresentamos representam uma pequena parte do quadro de urbanização de favelas do país, e um parte daquelas que poderíamos considerar como experiências militantes.

Nesta linha do tempo recriada reconhecemos a importância das gestões públicas seja na viabilização ou na dificultação dos processos. Ao mesmo tempo reconhecemos que os recursos públicos liberados por programas facilitaram o desenvolvimento de projetos e obras.

Nesta seleção verificamos o empenho de certos sujeitos aplicados na tentativa de resolver processos e intervenções em favelas. Nos entraves que foram colocados e que aqui fomos exemplificando este esforço é defrontado com uma parte de desânimo e frustração, o que para muitos de nós ${ }^{66}$ pode implicar até a desistência. Nos sujeitos aqui selecionados e nos depoimentos que recolhemos, também encontramos essa frustração e alguns pensamentos de desistência, mas a maioria dos sujeitos presentes nesta exploração continuam a sua ação e atividade junto a favelas e arriscam possibilidades que permitam o seu enfrentamento, seja na pactuação com gestões mais conservadores ou através de ações alternativas às colocadas, fora das regras estabelecidas, nas relações oficiais de contratação.

Todos reconhecem a importância da formação. A maioria procurou o caminho da educação, inclusive para explorar o conhecimento que havia acumulado e partilhar as experiências empíricas que foram desenvolvendo.

$\mathrm{Na}$ Parte II vamos aprofundar algumas das práticas empregues e exploradas nestas experiências pelos arquitetos militantes. Recorremos à apresentação dos sujeitos - no Cap. I e ao enquadramento histórico e programático - apresentado no presente Cap.2, para possibilitar uma reflexão contextualizada de cada uma das práticas - apresentadas no Cap.3, tendo em consideração cada sujeito, o momento histórico em que se enquadra e a favela para a para foi destinada e na qual foi utilizada.

\footnotetext{
66. Partilho da reflexão

a partir da minha

experiência como

arquiteta projetista em

urbanização de favelas.
} 


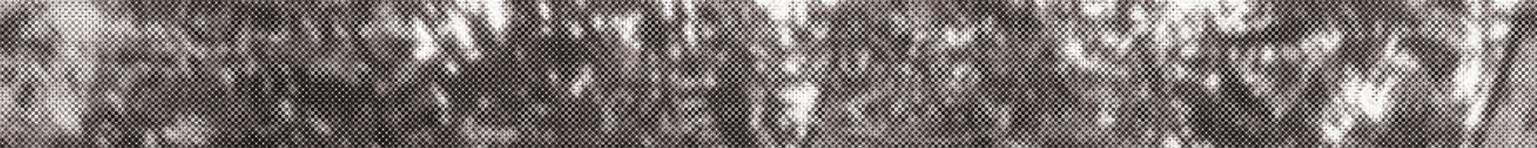

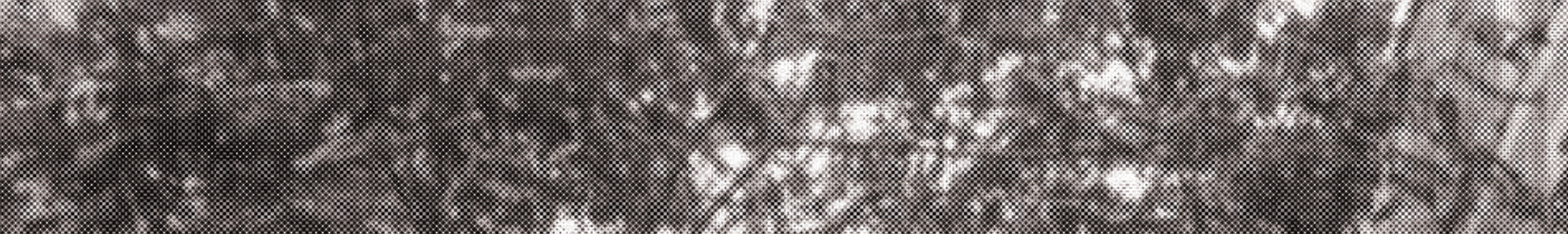
-

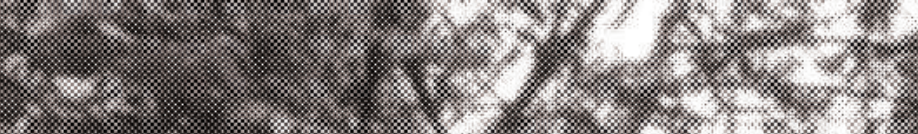

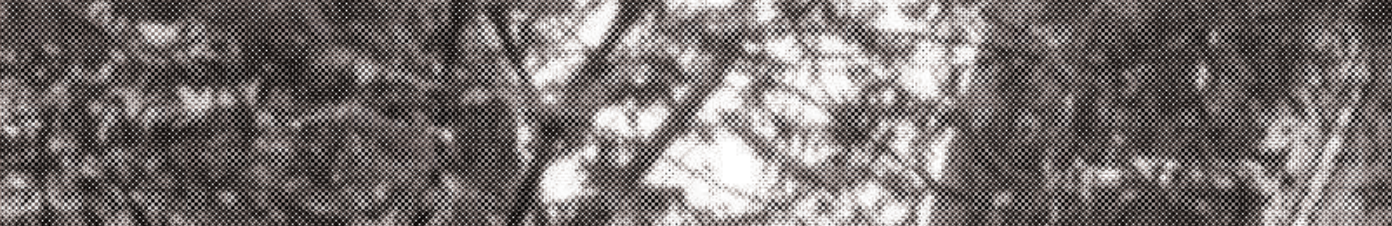

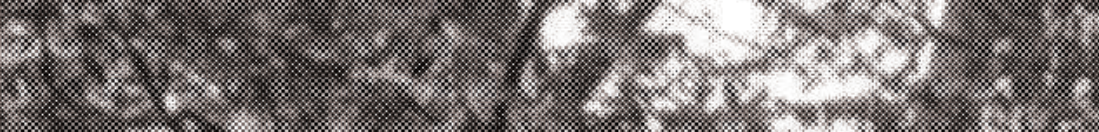

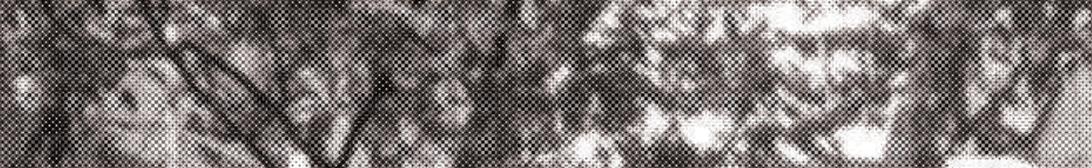
-

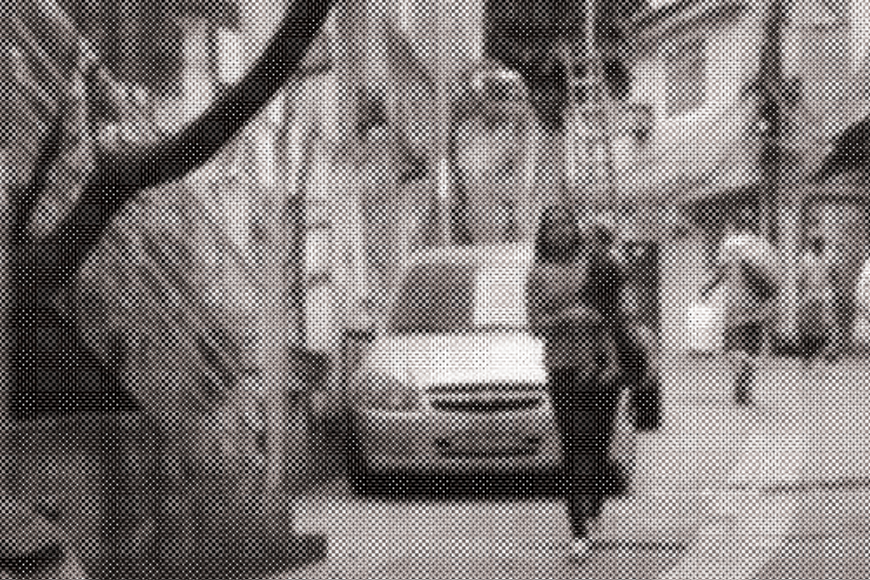

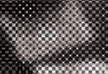
)
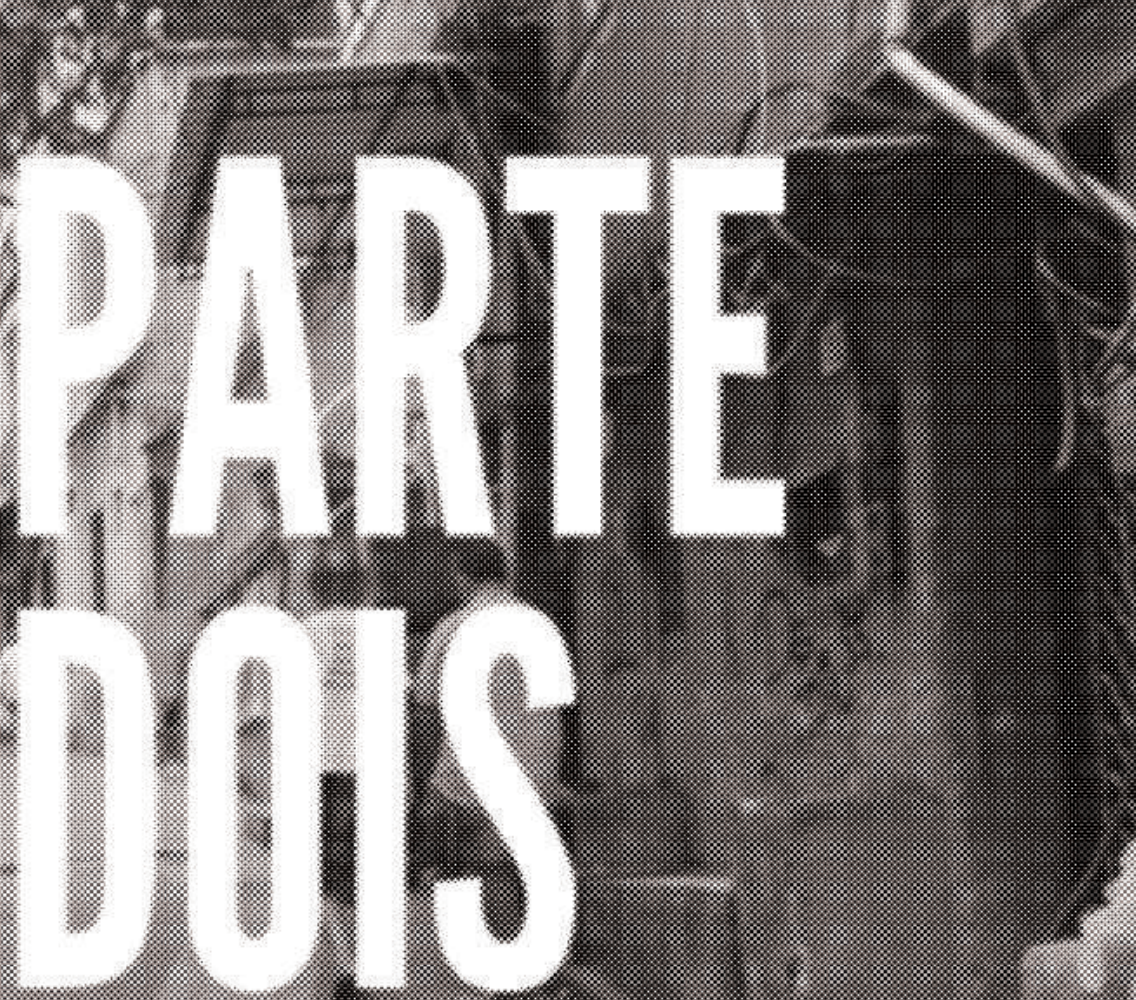


\section{CAP.3 PRÁTICAS}

\section{MILITANTES NA}

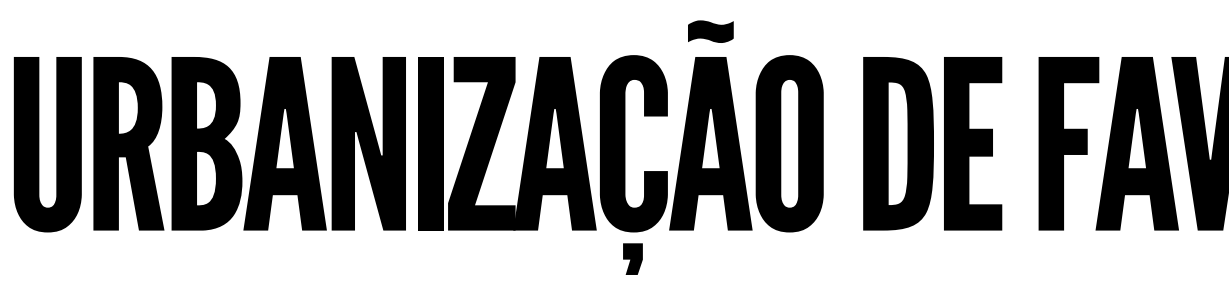

O processo de Urbanização de Favelas é comumente dividido em etapas semelhantes às usualmente praticadas no exercício da arquitetura: levantamento, diagnóstico, projeto e obra - o que define formalmente os momentos de desenvolvimento do processo, ainda que estes, na prática, não sejam estanques, sobretudo na visão dos arquitetos militantes, como veremos neste capítulo.

Esta divisão é imposta em grande medida pela formação na área, pela prática profissional, e ainda, pelos habituais formatos de contrato que, por sua vez, seguem os modelos definidos por programas financiadores ${ }^{1}$. Por exemplo, nos contratos de Urbanização de Favelas é comum a definição de produtos gráficos que são usados nas medições contratuais como comprovante do trabalho desenvolvido pelos projetistas em determinada etapa.

Para o levantamento e diagnóstico, os projetistas apresentam plantas, e outros elementos gráficos que representem a leitura do lugar. Para projeto é definida outra série de desenhos que garanta a representação da proposta urbanística e de todas as disciplinas associadas. A obra pode ser contratada por administração direta ${ }^{2}$ ou por empreitada global, formato que tem sido mais comum a partir da generalização de grandes linhas de financiamento (por exemplo, o PAC UAP). O envolvimento, e consequente medição do trabalho do projetista em obra, depende da sua inserção nesta etapa. No caso da sua participação ativa, o que aconteceu mais nos anos 80 e 90 do que atualmente, o projetista terceirizado era contratado na lógica de administração direta, e pago consoante o andamento da obra. Na lógica de empreitada global, como atualmente se têm contratado Urbanizações de Favelas, o projetista só é chamado para a etapa de obra por imposição do contratante, por exemplo, a secretaria municipal responsável pelo processo, ou como subcontratado da construtora responsável pela execução. (PETRAROLLI, 20 I 5 )

Dada esta limitação, o aumento significativo dos números de contratos realizados para Urbanização de Favelas nos últimos Io anos, e o fato de poucos terem sido concluídos em obra, arriscamos dizer que as etapas de levantamento/diagnóstico e projeto têm sido mais desenvolvidas e experimentadas por projetistas do que a etapa de obra ${ }^{3}$. Essa é também uma constatação para os sujeitos que selecionamos e que nos servem de estudo nesta pesquisa, mesmo que tenhamos procurado sujeitos com experiência nas 3 etapas designadas. A metodologia de pesquisa e seleção dos sujeitos está descrita na Introdução desta dissertação. A exploração analítica que apre-
I. É o caso do PAC UAP, mas antes dele também outros programas de financiamento federal, que por sua possibilitaram a implementação de programas municipais como o Favela-Bairro, o PIIS ou o Santo André Mais Igual, como colocado no capitulo anterior. Os programas contribuem para o regulamento dos modelos de contratação o que influencia as possibilidades de desenvolvimento de determinado processo.

2. Esta forma de contratação não tem sido utilizada recentemente, mas, a partir das informações orais das entrevistas exploramos alguns exemplos disso nos casos da Vila Popular (Diadema), Serrinha (Rio de Janeiro) e Tamarutaca (Santo André). Podemos também supor, pela descrição do processo, que Brás-de-Pina 
também se tratou de uma contratação por administração direta (SANTOS, I 98 I).

3. Esta informação parte

da análise dos casos aqui apresentados, mas também de uma leitura a partir das discussões realizadas no GE_Favelas.

Alguns estudo como

Moretti et al. (2OI 5$) e$ PETRAROLLI (2OI 5), reforçam esta reflexão.

4. Esta é apenas uma das críticas colocados pelos arquitetos militantes à Urbanização de Favelas como tem sido praticada ultimamente. Abordaremos outras críticas e contribuições analíticas feitas por estes sujeitos mais à frente neste capitulo.

5. Em alguns casos a prática não chega a se efetivar, por alguma limitação inerente ou imposta por fatores externos, mas no discurso do sujeito fica evidente a vontade de que essa prática poderia valorizar ou facilitar o processo de urbanização de favelas. Isso será aprofundado na apresentação de cada uma das práticas adiante.

6. Referimo-nos como discursos, às entrevistas e às comunicações públicas destes sujeitos, também utilizadas como material base desta pesquisa. sentamos em seguida vai refletir esse acúmulo concentrado no exercício de levantamento, diagnóstico e projeto, procurando estender a análise à obra, mas é possível adiantar, que sobre esta, as informações coletadas oralmente e graficamente são mais escassas, devido ao fato dos arquitetos estarem cada vez mais alijados dos processos de implantação nos contratos em favelas - como se verá pelas fontes verbais advindas das entrevistas realizadas.

O que é comum nestes sujeitos entrevistados é o questionamento sobre esta divisão por etapas do processo de Urbanização de Favelas. Essa posição é resultado da longa experiência com Urbanização por parte da maioria destes sujeitos, mas também do sentido de praticidade dos mesmos (como vamos expor em seguida), e pelo entendimento que eles têm sobre a intervenção nestes territórios.

Com base nas entrevistas, podemos adiantas que, para os arquitetos militantes, Urbanização de Favelas trata-se de um processo complexo que precisa de ser adaptado a cada lugar e cada contexto físico e também social, e que portanto não pode ser definido em etapas impostas a priori. ${ }^{4}$

Contudo, e apesar dos questionamentos sobre a separação rígida por etapas, encontramos estes sujeitos a executarem processos de Urbanização de Favelas, dentro das regras e condicionantes impostas por contratos e programas semelhantes aos demais. Nestes contextos, os militantes respondem formalmente, tal como os demais, aos produtos e demandas exigidas para cada etapa, no entanto, nas práticas que propõem ou reivindicam ${ }^{5}$ para o desenvolvimento do processo, trespassam essa separação, interpenetrando sua atuação entre levantamento, diagnóstico, projeto e obra.

Falamos em Práticas por se tratarem de ações concretas, mas também de posturas que refletem diretamente sobre o processo, que aparecem com certa recorrência nos processos analisados, assim como nos discursos destes sujeitos ${ }^{6}$. Reconhecemos que apenas o sujeito como ser consciente, social e político, pode ser designado como militante pelas suas ações e reflexões, no entanto, alargamos aqui o conceito à prática, para agruparmos dentro de algumas nomenclaturas, ações e posturas semelhantes, mesmo que realizadas em momentos e contextos diferentes e por sujeitos distintos. Apresentamos em seguida uma série de PRÁTICAS MILITANTES identificadas na análise dos processos de urbanização de favelas realizadas pelos sujeitos selecionados para este estudo.

Esta sistematização é resultado do desenvolvimento da pesquisa que se baseia em grande medida em informações verbais, como já dito anteriormente, a partir das entrevistas semiestruturadas realizadas junto aos sujeitos pesquisados, e a leitura de material de referência correspondente às suas intervenção, práticas e currículos profissionais. A apresentação da análise em práticas militantes e não por etapas de processo como inicialmente havíamos proposto, tornou-se uma opção de sistematização analítica do objeto de pesquisa a partir dos comentários, críticas e reflexões que os sujeitos, casos de estudo, fizeram como participantes ativos de processos de Urbanização de Favelas. A nomenclatura dada a cada conjunto de práticas semelhantes, é também, em alguns casos, sugerida por um ou vários sujeitos como veremos em seguida. Agrupamos estas práticas pela sua semelhança de enquadramento e atuação mas admitindo que elas se inter-relacionam nos processos. Nem sempre encontramos todas estas práticas nos processos analisados ou relacionando-se da mesma forma. É comum que uma prática lembre outra, ou só aconteça na interdependência com outra ainda.

A série que se segue, não pretende ser excludente, assim como a seleção destes su- 
jeitos. Talvez haja outras práticas imbuídas nestes discursos e atuações que aqui não conseguimos identificar, e outras ainda que possam ser associadas à militância destes ou de outros sujeitos em urbanização de favelas. Mais uma vez, lembremos que esta não pretende ser uma restrição à denominação ou categoria militante em urbanização de favelas, apenas uma exploração a partir de casos que pretendem representar certa diversidade de processos, contextos e resultados, para compreendermos o contributo de ações de sujeitos militantes na intervenção em favelas.

A utilização da entrevista como instrumento base da metodologia de pesquisa aqui apresentada leva à análise através de relatos advindos da memória e da opinião de cada um dos sujeitos. Assumimos o instrumento, considerando as possíveis lacunas de rigor que podem resultar de relatos que são pessoais e às vezes parciais. Ao mesmo tempo, através da entrevista, podemos explorar as autorreflexões e análises críticas sobre o trabalho que estes sujeitos têm desenvolvido, e como eles se reveem e posicionam sobre o mesmo.

\section{PRÁTICA: A “IMERSÃO"}

Começamos a exploração das práticas militantes a partir da aproximação do arquiteto à favela. Conhecer a favela de forma intrínseca é fundamental para todos os sujeitos abordados. Só a partir do convívio e da vivência regular é possível concretizar leituras das quais resultam propostas para o território e sua população.

Ao momento de contato para conhecimento do lugar, normalmente associado à etapa de levantamento e diagnóstico, Manoel Ribeiro, vai chamar de "imersão". No seu caso, para o projeto realizado na Serrinha (RJ, I 996-200 I), este momento de imersão se alargou por cerca de 6 anos, desde as primeiras leituras e projeto, durante os primeiros 6 meses nos quais conviveu quotidianamente na favela e com os seus moradores, até à conclusão da obra que acompanhava regularmente. Manoel afirma que a fase de conhecimento é fundamental para a definição das diretrizes de projeto. Ele reclama que uma vivência aproximada deve ser feita com tempo (mínimo de 6 meses) e pelo próprio projetista. 


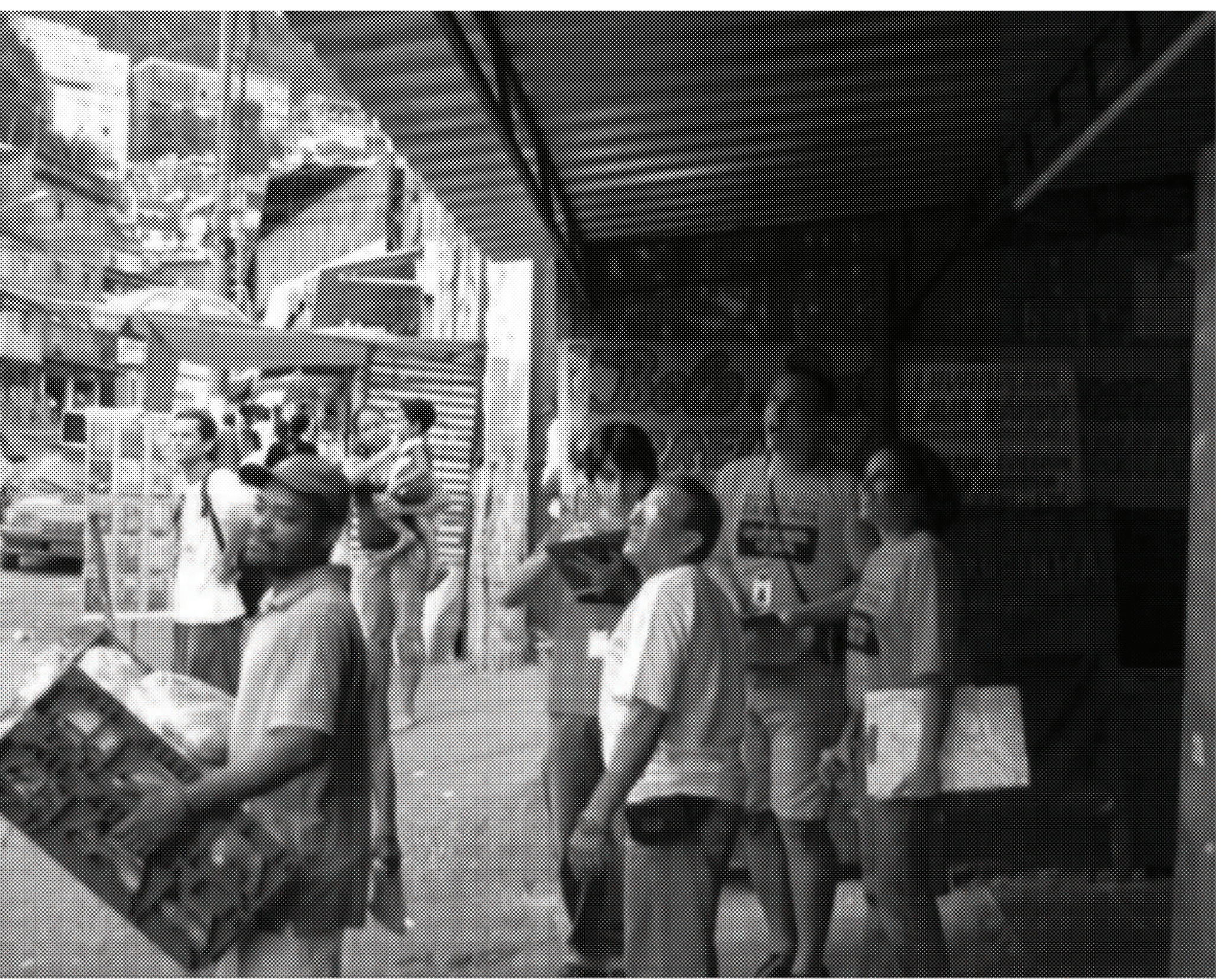

foi possível a contratação de uma extensa equipe com uma grande percentagem de moradores, o que facilitou a mobilização e reconhecimento das questões da extensa favela.

Ninguém chamava as pessoas de dentro da Rocinha para trabalhar lá. Para além do PC e do Edigrê10, contratei mais 30 e poucas pessoas para trabalhar lá [da própria favela]. (TOLEDO, 2015, informação verbal ${ }^{11}$ )
Isso foi ainda facilitado pela decisão de Toledo de abrir uma filial do seu próprio escritório dentro da comunidade, levando ao extremo a expressão de "imersão" e permitindo a vivência quotidiana da equipe dentro da Rocinha.

"Montar o negócio na favela, foi ideia do Toledo. Eu estava morrendo de medo do ponto de vista legal do que significava isso. (..) mas ele assumir isso, o risco, porque a EMOP nunca
Io. Os moradores PC e

Edigrê, teriam sido os responsáveis pelo convite para que Toledo participasse do Concurso da Rocinha. Fizeram parte da equipe desde as primeiras propostas para o Concurso

(TOLEDO, 2015 , informação verbal, em entrevista realizada em 


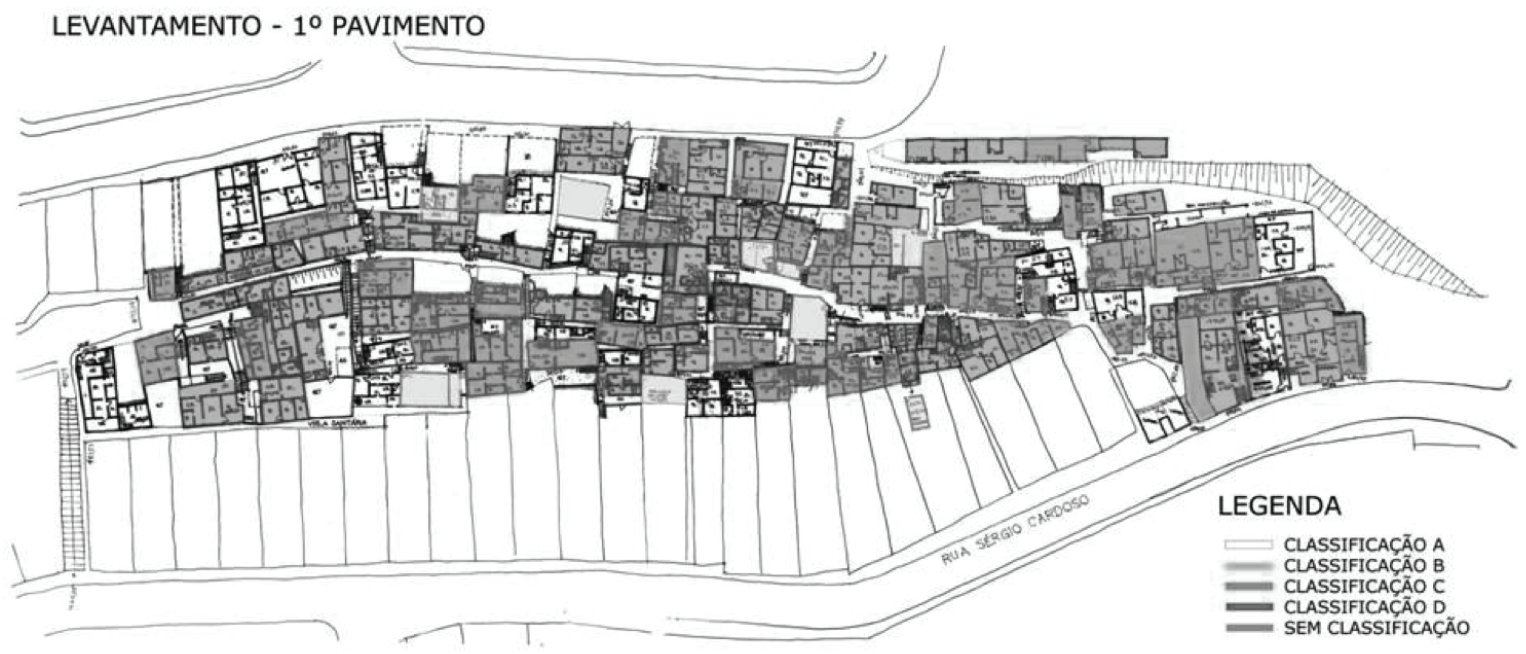

LEVANTAMENTO - $2^{\circ}$ PAVIMENTO

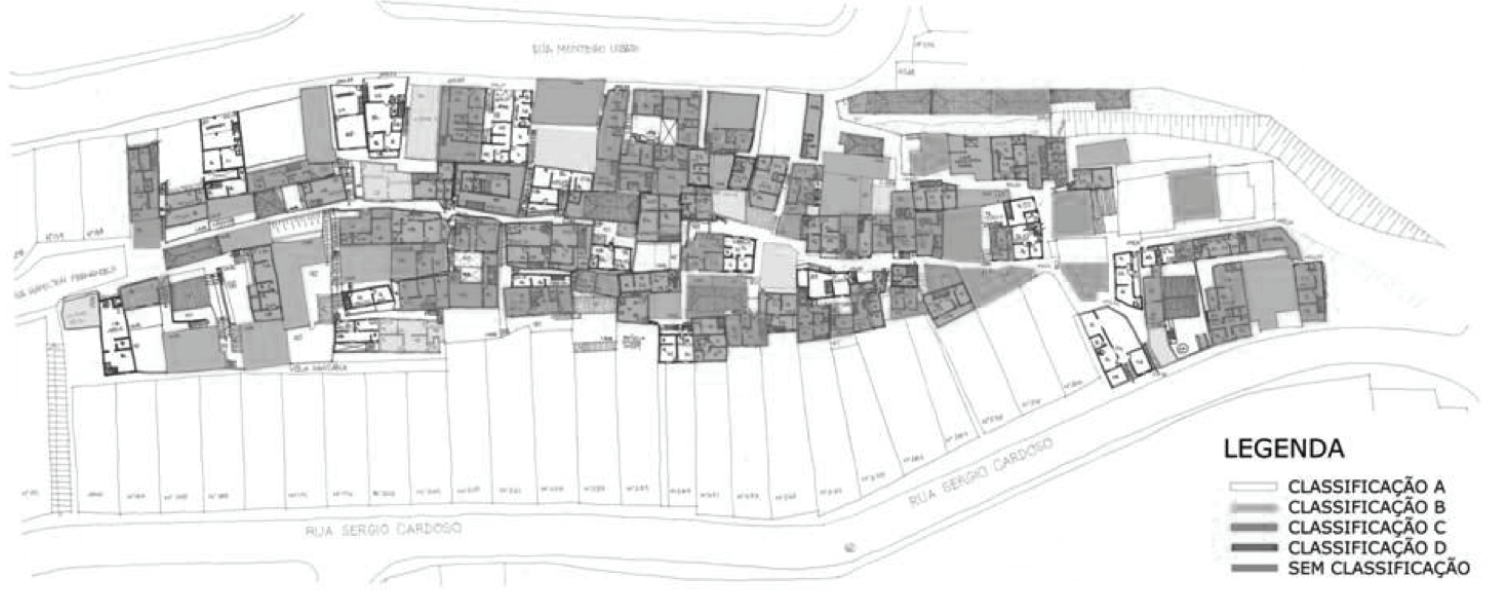

LEVANTAMENTO - $3 \circ$ PAVIMENTO

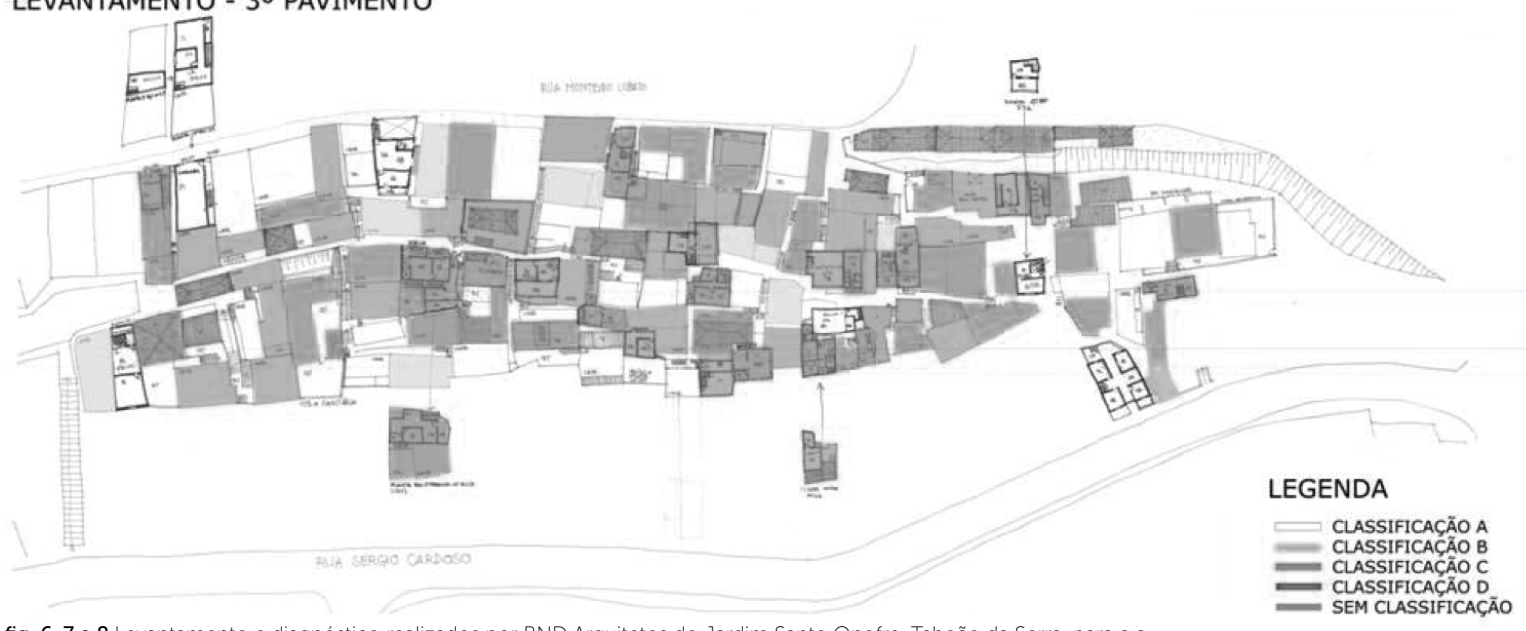

fig. 6,7 e 8 Levantamento e diagnóstico realizados por BND Arquitetos do Jardim Santo Onofre, Taboão da Serra, para a a 

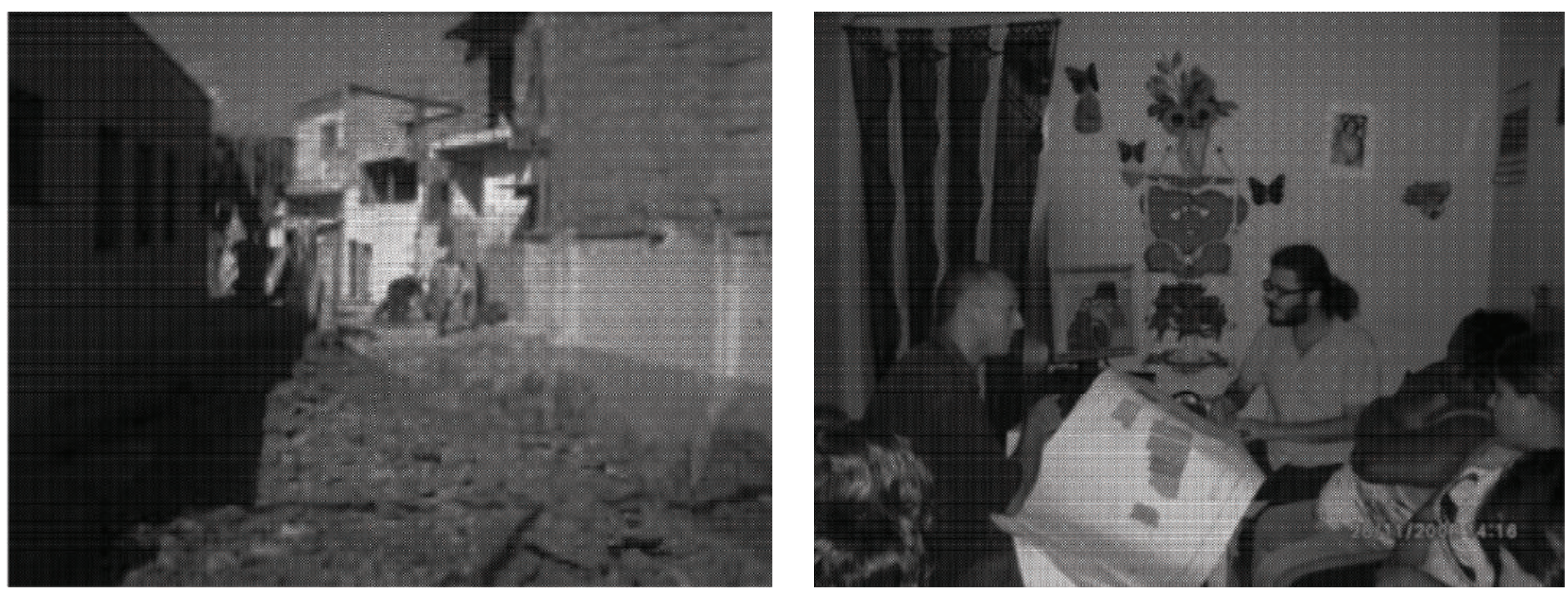

fig. 9 e 10 Trabalhos no Jardim Sílvio Sampaio, Taboão da Serra, com o acompanhamento da equipe da prefeitura. Implantação de esgosto e drenagem e assessoria técnica para as familias da comunidade. Fonte: cedidas Heloisa Rezende

$$
\begin{aligned}
& \text { I4. Entrevista realizada } \\
& \text { em 27/I I/2015, São } \\
& \text { Paulo. }
\end{aligned}
$$

I5. A permanência em campo e o desenvolvimento de projeto ou adequação do mesmo durante a obra será melhor explorado na Prática: PROJETISTA DE CANTEIRo.

16. Entrevista realizada em I 7/IO/20I6, São Paulo.

17. Entrevista realizada em I 4/I 2/20 I 5, São Paulo.
Em Brás-de-Pina, RJ ( I 968- I 97 I), Carlos Nelson e seus colegas viviam durante o dia na comunidade, recolhendo as informações necessárias que alimentavam ou alteravam o projeto em desenvolvimento:

\section{Só para se ter uma ideia de como se trabalhava naquela época, basta dizer que eu ia à favela quotidianamente, passava o dia lá e chegava à noite ao escritório com os dados necessários para que fosse revisto todo o planejamento anterior! No dia seguinte, enquanto eu estivesse em campo outra vez, eram refeitos os mapas, desenhadas plantas e modificados esquemas... (SANTOS, 1981, p. 65)}

Na Vila Popular (Diadema, I 994I 995), para USINA o interesse aprofundado pela área de intervenção e sua população levavam à confirmação constante in loco, de dúvidas que iam aparecendo durante a etapa de projeto. Se os dados dos mapeamentos sobre os quais trabalhavam no escritório, indicavam alguma dúvida que poderia influenciar as decisões de projeto, como por exemplo, a possibilidade de soleiras mais baixas do que a via adjacente, o que implicava a decisão sobre as infraestruturas de água, saneamento e drenagem, a equipe deslocava-se ao território para verificar essa constatação, e também para averiguar a possibilidade de uma solução, que muitas vezes precisava de ser acordada entre vizinhos. (GERMANO, 20 I 5, informação verbal ${ }^{14}$ )

Também no desenvolvimento do projeto para o Jardim Sílvio Sampaio em Taboão da Serra (2006-20 I I), a equipe da qual Heloísa Rezende participava, estava constantemente em campo recolhendo informações enquanto desenvolvia projeto no escritório. Neste caso, também a obra acontecia simultaneamente. ${ }^{15}$ (REZENDE, 20 I6, informação verbal $\left.{ }^{16}\right)$ A presença constante da equipe dentro da favela permite, para além do conhecimento sobre as características locais e outras considerações já colocadas, o reconhecimento do papel da equipe projetista (ou poder público) por parte da população local. Milton reforça a impor- 
tância desta presença constante, que no Chafik-Macuco, Mauá (20 I 3-20 I 5): "Uma coisa que não dá para abrir mão é a presença da equipe durante aquele processo. (...) A permanência constante da equipe da prefeitura na área, é uma forma de não fazer envelhecer [ou atualizar constantemente] as informações para projeto" (NAKAMURA, 20 I 5 , informação verbal ${ }^{17}$ ). Num caso como Chafik-Macuco onde o projeto, em 20 I 5 , já acontecia há dois anos, as visitas constantes da arquiteta e da assistente social foram fundamentais. Caso contrário, o projeto poderia ser descartado porque não teria validade de adaptação. Isso facilitou a aceitação e reconhecimento, por parte da população moradora, da existência de um processo de urbanização a decorrer e a atualização constante das informações dos levantamentos que em assentamentos informais têm associado uma grande variabilidade e transformação. (NAKAMURA, 20 I 5 , informação verbal ${ }^{18}$ )

Para além de tudo isto, a "imersão" como aqui foi colocada e praticada por estes sujeitos, facilita a criação de relações e proximidades entre os diversos atores, sobretudo projetistas e moradores, o que será melhor abordado nas Práticas: Participação como EmancipaÇão e Comunicação Acessível.

A imersão como prática, pode ser realizada por qualquer profissional, o que acontece muitas vezes gratuitamente, inclusive, como necessidade de pesquisa, para a compreensão de relações sócio espaciais. No entanto, o que verificamos no caso dos militantes, é enraizamento com a realidade estudada, no seu comprometimento que vai além do diagnóstico formal, e se encontra no seu modo de olhar a favela, moldado para o respeito à autoconstrução, tratando-se de um exercício da leitura da precariedade e da informalidade, não no sentido pejorativo, e simplesmente a ser solucionado, mas como condicionantes que são induzidas à população mais pobre de cidades e países que espacializam condições de maneira desigual.

\section{PRÁTICA: ANTROPOLOGIA \& ARQUITETURA}

Se associarmos à prática da "imersão", a experiência e sensibilidade características destes sujeitos, encontramos leituras dos militantes que ultrapassam apenas as questões físicas e materiais. Os militantes lembram-nos da importância das imaterialidades e aspetos culturais e sociais destes lugares, numa reflexão direta em suas propostas. É comum, nestes processos, encontrarmos leituras que aproximam a antropologia do planejamento físico urbano.

Carlos Nelson inaugura nas leituras em favelas uma aproximação com o campo disciplinar da antropologia, ele por exemplo, já se intitulava "antropoteto" ainda antes de se aproximar formalmente da disciplina. A sua auto-nomeação inicia-se através das sua práticas em Brás de Pina ( I 968), mas só em

\footnotetext{
18. Entrevista realizada

em I 4/I2/20I5, São

Paulo.
} 


19. Através de Anthony
Leeds foi introduzida a
observaçáo partici-
pante, aos modos da
Escola de Chicago, para
a o estudo das favela
do Rio de Janeiro. Seus
estudos são referência
nacional e internacio-
nal na antropologia
e sociologia urbana,
conversando compara-
tivamente com outros
estudo sobre a pobreza
urbana realizados na
América do Sul, entre
eles os do arquiteto John
Turner no Chile e Peru
(VALLADARES, 2005,
. I $)$.

I 974, é que Carlos Nelson entra no programa de pós-graduação do Museu Nacional da Universidade Federal do Rio de Janeiro, concluindo o mestrado em Antropologia Social em I 979. O Museu segue sendo até hoje, uma referência em estudos urbanos, inclusive com um foco direcionado para as favelas.

A exposição à favela [Brás de Pina] e ao quotidiano dos favelados teve um efeito curioso. Comecei, cada vez mais, a desviar a minha atenção das casas, dos sistemas de aglomerados, das soluções de esgoto e abastecimento de água e de outros aspectos considerados do interesse primordial de um urbanista ou arquiteto. (...) De observador de padrões e arranjos dos espaços públicos e privados, fuime transmutando em observador de inter-relações sociais e das redes de significados que, como ia percebendo, era o que, de fato, os sustentava tanto ou mais do que as razões materiais ou práticas, em cujo inconteste predomínio acreditava, ao entrar nas favelas como neófito.

Assim, fui virando uma espécie de antropólogo ad hoc. Desde 1968, passei a ter contatos regulares, por força dos trabalhos que executava, com gente ligada às ciências sociais. Foi quando conheci Machado da Silva. No mesmo ano, me tornei amigo de Anthony Leeds, cujo curso sobre antropologia urbana no Museu Nacional, ministrado em 1969. acompanhei na qualidade de ouvinte. Aos poucos ia virando o que chamava, de brincadeira, de 'antropoteto'." (SANTOS, 1981, pg 13) $)^{19}$.

Da observação sobre as arenas, seus atores e suas relações, vão resultar ou se alterar as suas propostas territoriais. Vale lembrar a contribuição de Carlos Nelson para a transformação do lugar comum do arquiteto, aproximando-o das realidades urbanas menos ousadas por estes profissionais no Rio de Janeiro. (SANTOS, I 98 I , e PULHEZ, 2008)

É isso que fez também Manoel Ribeiro na Serrinha, RJ ( I 996-200 I). A sua leitura sobre o território levou ao reconhecimento sobre a ocupação histórica e social do espaço físico. Para Manoel, não se tratava de uma mas de várias comunidades, que se diferenciavam pela sua origem, etnia, cultura e, até, morfologia de ocupação. Isso é parte do diagnóstico um
mapeamento que eu fiz um
zoneamento [por etnias e por faixas
de renda], por exemplo, esse cinza
aqui, são os negros, que originalmente
chegaram aí. (...) Aqui já é cidade
formal. Aqui já é a rua principal de
Madureira. Então, os negros subiram
por aqui, por essa rua, que éa Balaiada 


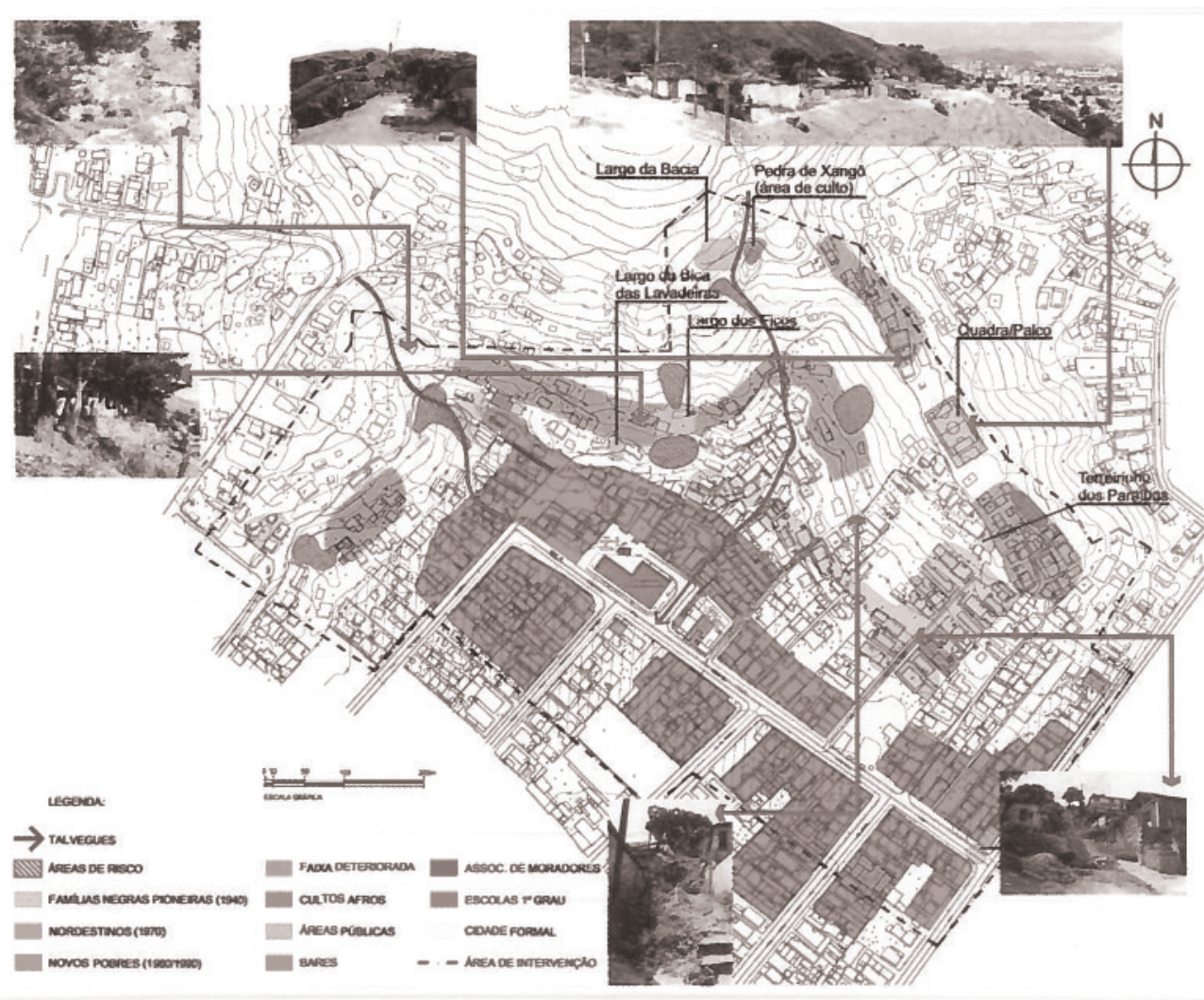

e se ocuparam aqui. Aqui foi criado o Império Serrano, e tinha o Jongo e tal, que vieram aqui na encosta e tem mais uma manchinha aqui. Então esses são os negros pioneiros.

Essa mancha amarela é quando - morro muda de declividade. Então era um lugar que tinha muito escorregamento de terra, tinha uns talvegues marcados aqui em azul. Aqui era um 'lumpém': viúvas de traficante, alcoólico, desempregado, era o lugar mais... ruinzinho da favela. Os nordestinos ficaram no topo do morro que era um lugar relativamente plano, e eles não tinham prática de trabalhar em encosta, fizeram tipo uma aldeia nordestina, mas lá em cima, trabalham em construção civil, botaram uma bomba, botaram água lá em cima. Resolveram.

E aqui, no fundo dos lotes que dava para a rua principal (...) chegaram os novos pobres da crise de 80/90.

Os caras daqui venderam os fundos desses lotes para esses caras. (RIBEIRO, 2015, informação verbal'20)

As decisões de projeto, como a simples proposta de abertura de uma via, ou a implantação de uma praça em determinado lugar, vão responder a estas características e suas interdependências. $\mathrm{O}$ conhecimento aprofundado da(s) cultura(s) local(-ais) e o reconhecimento da sua "vocação" ${ }_{21}$, permitiu uma proposta para a exaltação das práticas culturais já existentes na favela, como o jongo ${ }^{22}$, através da criação de "palcos de cultura". A proposta englobava pequenas praças pulverizadas no território, cada uma com uma função específica dentro da comunidade. A sua proposta refletia a vontade da população, e a crença da sua função como projetista de que, mais do que levar infraestrutura para a favela, deveria transformar aquele como um lugar fig. 11 Diagnóstico da Serrinha (RJ) realizado por Manoel Ribeiro, com a identificação das diferentes comunidades dentro da favela. Fonte: RIBEIRO, 2004. 2o. Entrevista realizada em 20/I I/2015, Rio de Janeiro.

2 I. VoCAÇÃO é o termo utilizado por Ribeiro (2015) que remete para as potencialidades que através do diagnóstico de um local, ele identifica. O conceito será utilizado neste texto como referência ao termo utilizado pelo sujeito entrevistado. Atentamos, no entanto, para que a sua utilização não induza em erro, já que um local não possui vocação inata, nat- 


\footnotetext{
ural, pois esta é oriunda

de processos construidos

socialmente, e portanto

só designadas a sujeitos

sociais.

22. O JONGO é uma dança

brasileira de origem afri-

cana praticada ao som de

tambores. Tem influência

na formação do samba

carioca. A Serrinhaé um

dos principais pontos $d a$

sua manifestação no Rio

de Janeiro. Foi construida

no bairro recentemente a

Casa do Jongo.

23. Pelo relato de Ribeiro

(2015), a antropóloga

terá usado a expressão

francesa: "Vous faites

d'Antrophologie sans savoir?'

remetendo à conhecida

Escola de Antropologia

Urbana francesa.

24. Entrevista realizada

em 20/II/2015, Rio de

Janeiro.

25. Idem

26. Idem.

27. Entrevistas realizadas

em 20/I I/2015, Rio de

Janeiro e 26/10/2015,

São Paulo, respectiva-

mente a Manoel Ribeiro e

Jonathas Silva.
}

apelativo e a ser vivido por toda a cidade. O seu conhecimento sobre aquele território e as suas propostas que enalteciam as potencialidades locais, levariam ao comentário de uma amiga antropóloga que certa vez visitara a Serrinha: "Você faz Antropologia sem saber!”23 (RIBEIRO, 201 5, informação verbal $^{24}$ )

"Na hora do diagnóstico, o jogo é você entender quais foram as condicionantes que deram aquela forma, como é que aquilo é usado, e eventualmente, qual é o papel que aquele assentamento, aquela população tem no drama urbana onde está envolvido!" (RIBEIRO, 2015, informação verbal ${ }^{25}$ )

Como consultor, em Cantagalo e $\mathrm{Pa}$ vão-Pavãozinho, RJ ( I 999-2003), Manoel foi responsável pela percepção sobre a formação das duas comunidades e suas características sociais que mais se evidenciavam. Manoel entende aquele território inserido no meio da Zona Sul do Rio de Janeiro, como um espaço facilitador da integração da população na região e economias locais para indivíduos ou grupos migrantes. A localização destas favelas inseridas numa das áreas mais ricas e valorizadas da cidade permitia o acesso ao mercado de trabalho de turismo, hotéis, bares e restaurantes. "O $\mathrm{Pa}$ vão-Pavãozinho é o mecanismo de inserção de migrantes nordestinos na economia ur- bana de Copacabana, melhor que o Sistema Nacional de Emprego." (RIBEIRO, 20 I 5 , informação verbal ${ }^{26}$ )

Nestas favelas polvilhavam pousadas e locações temporárias de quartos, assim como outros usos comerciais, com bares e restaurantes que funcionavam $24 \mathrm{~h}$ garantindo os serviços necessários aos trabalhadores que ali residentes. Para este entendimento, Manoel vai recorrer à conversa com moradores mais velhos que por um lado facilitavam a construção da história local, e por outro, validavam pelo respeito inerente a tais figuras, a ação da equipe projetista (RIBEIRO, 20 I 5 e SILVA, 20 I 5 informação verbal ${ }^{27}$.

(...) daqui sai uma rua que passa aqui pelo Cantagalo e vai para o Pavão Pavãozinho onde tem os hotéis e as pensões e o comércio, e aqui desce para Copacabana. Aqui, tinha a escola de Samba Unidos da Zona Sul, fruto da fusão das duas escolas de samba quando unificaram o tráfico, aqui adiante, tinha um pátio que era o antigo pátio da escola de samba do Pavão, que chamava Pátio das Serestas, onde os velhos iam lá... até aqui, a população é negra, daqui para lá a população é nordestina, aí tinha o restaurante $24 \mathrm{~h}$ do Biu. Muita gente trabalhando à noite, prostitutas, travestis, gente que limpa supermercado, que chega 


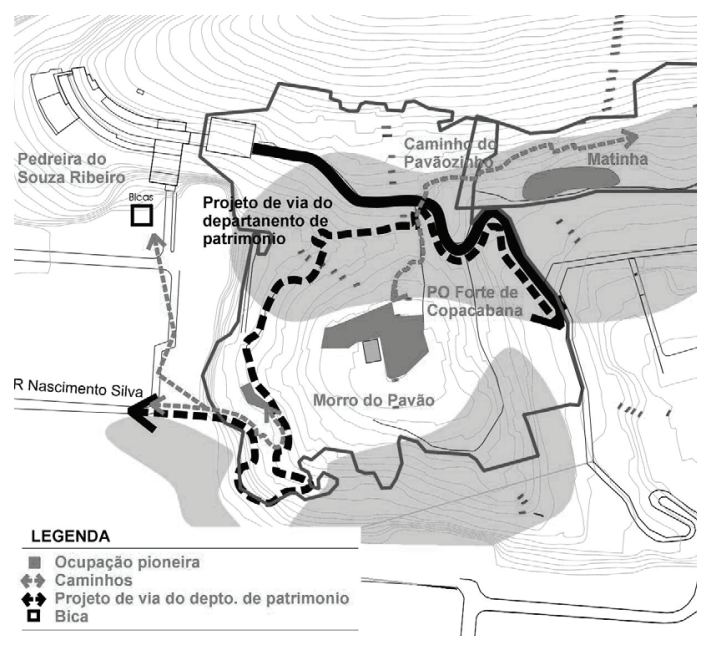

na madruga e que tem o restaurante funcionando, do Biu. Aí depois tinha - Pátio do Forró e a descida para Copacabana. Então, a gente projetou um corredor de cultura popular, e gastronomia, e hospedagem, ligando Copacabana e Ipanema pela favela - mas a Prefeitura ignorou isso completamente, passou por cima. (RIBEIRO, 2015, informação verbal'28)

O mesmo se rebate na fala de Wagner Germano, ao lembrar a importância e responsabilidade do projetista olhar para além do físico. De como as questões imateriais podem impactar na vida de uma comunidade: "Se você vai fazer um trabalho numa favela, então (...) tem que olhar para todos os lados, e conversar com as pessoas e entender não só a condição física daquele lugar, mas também entender a condição social.” (GERMANO, 20 I 5, informação verbal $^{29}$ )

Foi o que aconteceu na Vila Popular, Diadema ( I 994-I 995), segundo depoimento de Germano. Na necessidade de alargamento de uma via, o mapeamento de precariedades indicava, de um lado da rua, índices mais altos, e portanto, casas mais indicadas a remover. Do outro existiam habitações mais consolidadas, com melhores

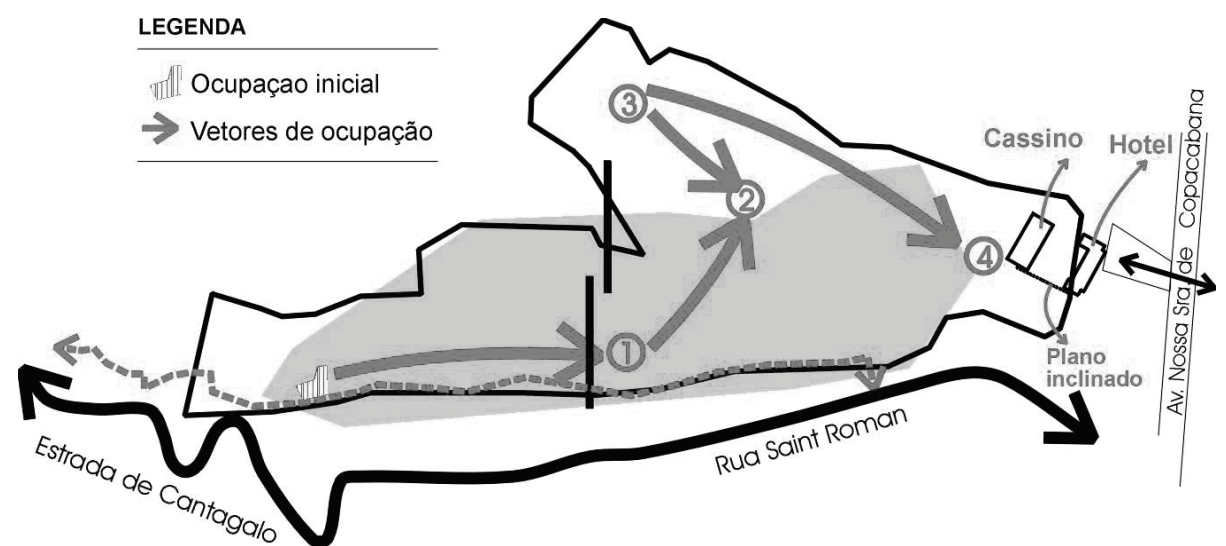

estruturas e inclusive com terrenos espaçosos, como o caso de um grande bar/restaurante. $\mathrm{Na}$ confirmação e conversa com os seus moradores, a equipe projetista descobriu a existência de uma moradora, do lado da rua mais precário, que funcionava como cuidadora para as crianças da comunidade. Removê-la (a área de relocação já estava definida e não era próxima do assentamento a urbanizar) implicaria a perda desta estrutura social, e provavelmente, a necessidade das mães deixarem as crianças sozinhas em casa, o que acontece em muitos territórios com as mesmas características durante o horário laboral. Assim, os projetistas, num acordo com os restantes moradores, propuseram a remoção parcial das construções do lado mais consolidado da rua. Esta decisão só foi possível pelo interesse constante da Usina pelo local e pela proximidade dos técnicos com a população o que permite definições de projetos menos impactantes para o tecido social (GERMANO, 2015 , informação verbal ${ }^{3 \circ}$ ). Esta aproximação, consideração e respeito pelo território e seus moradores é uma prática constante do método de trabalho da Usina, e que, pela voz de Germano, sublinha ainda a responsabilidade dos projetistas na resolução dos problemas de natureza social dos territórios, ou, pelo menos, na minimização do impacto fig. 12 e 13 Diagramas de análise da formação e relações de percurso em Cantagalo e Pavão-Pavãozinho (RJ). Fonte: cedidas por Jonathas Silva.

28. Entrevista realizada em 20/II/2015, Rio de Janeiro.

29. Entrevista realizada em 27/I I/2015, São Paulo. 30. Idem 
3. Idem causado pelas suas intervenções. (GERMANO, 20 I 5, informação verbal ${ }^{3 \mathrm{I}}$ )

Muitos arquitetos olham para dimensões socioculturais quando realizam projetos arquitetônicos. A radicalidade desse olhar no militante na favela está numa visão para áreas precárias que transcende a visão da favela como lugar da marginalidade, da malandragem, do crime, da pobreza. Há respeito com a morfologia do lugar, com o tempo, trabalho e recursos empreendidos na autoconstrução. Com as formas vernaculares e espontâneas de organização espacial, a arquitetura da casa, da cidade, com as formas de morar. Com as histórias do lugar, das pessoas, os laços e as relações construídas. Este não é o pensamento hegemônico no campo disciplinar da arquitetura e urbanismo, sobretudo quando se trata do lugar de moradia dos pobres: a precariedade tem recorrentemente justificado práticas de intervenção violentas, quando se propõem numa transformação radical destes tecidos, como no caso de remoção forçadas.

a prática dos militantes tensiona essa tradição. Por isso reforçamos a importância do caso de Brás de Pina, fadado à remoção, como emblemático para esta campo de atuação e literatura. Ligia Valladares (2005), revela-nos o seu caráter pioneiro de militância consciente, que tensiona o campo disciplinar para uma articulação com a antropologia, e com um pensamento inaugural sobre a favela no Brasil.
Os artigos escritos por Carlos Nelson Ferreira dos Santos trazem títulos que demonstram a inquietação do seu grupo [os Quadra Arquitetos] e a vontade de sua geração marcar uma diferença em relação aos arquitetos que defendiam pontos de vista e práticas tradicionais: "Estarão as pranchetas mudando de Rumo?" (Santos, 1978). "Como projetar de baixo para cima uma experiência em favela" (Santos, 1980). Esse grupo, QUADRA, foi contratado pela CODESCO e tornou-se responsável por uma experiência pioneira única, em que arquitetos e moradores redesenharam juntos bairros e casas, dentro de um processo de aprendizado mútuo em que a liberdade de escolha dos habitantes foi respeitada. (VALLADARES, 2005, p.134)

A tríade ética/estética/técnica aqui aparece deliberada na prática dos Quadra Arquitetos, que foi amplamente divulgada por Santos, e iluminou direta, ou indiretamente, gerações posteriores de militantes, como se pode verificar. Carlos Nelson tensionaria essa 'antropotetura' aos limites, a ponto de ensejar projetos desenhados com moradores, questionar as remoções, recusarse a desenhar layouts, se expondo na prática um entendimento de uma recusa deliberada da postura do arquiteto que 'ensina 
como morar'. Dessa sua forma de exercer a profissão, enseja-se sobretudo no Rio de Janeiro uma forma de urbanizar favelas menos intervencionista do que em outros lugares do Brasil. Talvez mais respeitosa com as pré-existências. Não cabe neste trabalho defender esta hipótese, mas mencionamos esta leitura, para estimular possíveis direcionamentos para esse campo de pesquisa.

\section{PRÁTICA: PARTICIPAÇÃO COMO EMANCIPAÇÃOO}

Nos processos que aconteceram nos anos 80, 90 e até alguns dos anos 2000, a participação social foi se constituindo em uma prática quase intrínseca à intervenção na favela no Brasil, e progressivamente sendo institucionalizada. $\mathrm{Nas}$ experiências pioneiras no campo da urbanização de favelas, como em Brás de Pina e na atuação da Prefeitura Municipal de Diadema nos anos 80/90, a mobilização e reivindicação sociais por melhores condições de vida foram, inclusive, ativadores de alguns dos processos que aconteceram e iniciaram a intervenção pública em favelas (DEDALDI, 2003). Como Milton Nakamura nos descreve pela sua experiência em Diadema ( I 989- I 996), as intervenções se davam com a presença constante e decisões tomadas no local pelo reduzido quadro técnico da prefeitura, recorrendo aos materiais e máquinas disponíveis, mas também à disponibilidade dos próprios moradores organizados em mutirão e participantes ativos das alterações físicas (NAKAMURA, 2015 , informação verbal ${ }^{32}$ ).

O Programa de Urbanização de Favelas estava totalmente concentrado na Prefeitura. "A primeira equipe teve grande importância para a construção do programa. Coordenada pelo arquiteto Luis Fingermann, compunha-se por um reduzido número de estagiários de arquitetura e dois funcionários públicos. Embora pequena, apresentava clareza de objetivos e era ideologicamente motivada pela justiça social e igualdade de direitos" (COELHO, 2008, p.39).

A execução era feita via contratação por administração direta através de uma "espécie de construtora interna" à Prefeitura equipada com algumas máquinas e trabalhadores contratados, e também equipe de projeto "bem capenga, mas um pessoal bem aguerrido". Os trabalhadores de obra resolviam os problemas no local, com a própria população afetada, inclusive com a sua contribuição em processos de mutirão. Nas palavras de Milton, "era uma ideia muito radical"! (NAKAMURA, 20 I 5, informação verbal ${ }^{33}$ )

Para a obra ia o arquiteto, o
topógrafo, o piquete, que falavam
diretamente com os moradores
para readequação dos "barracos". A
prefeitura trazia algum material mais

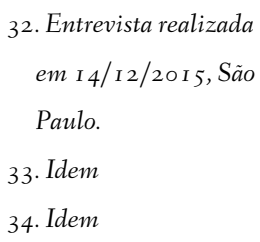

fig. 14, 15, 16 Implantação de obras de urbanização em Diadema (1983-1996). Para além dos técnicos e trabalhadores da Prefeitura. também a população era mobilizada em sistema de mutirão. Fonte: COELHO, 2008. 
Brás-de-Pina (RJ, I 968- I 97 I ), Tamarutaca (Santo André, 2000-2003) e na Serrinha (RJ, I 996-200 I ) encontramos os projetistas em diálogos diretos com os moradores, o que era facilitado pelo regime de administração direta na qual eram desenvolvidas as obras (e projeto ${ }^{35}$ ). Na Serrinha, Manoel Ribeiro entrava num acordo oral com os residentes, testemunhado e formalizado pela associação de moradores, como no exemplo típico que citamos na reprodução de sua fala a seguir:

Eu tiro um pedaço do teu quintal para alargar a esta rua, mas em 'troca' construo a sua laje! (RIBEIRO, 2015, informação verba( ${ }^{36}$ )

$\mathrm{Na}$ Tamarutaca, a Peabiru foi contratada para acompanhamento da implementação do projeto de espaço público e assistência técnica aos projetos individuais de cada casa dos moradores que permaneceram na
35. Sobre a relação entre projeto e obra ver Prática: Projetista de Canteiro.

36. Entrevista realizada em 20/I I/20I5, Rio de Janeiro. fig. 17 e 18 Implantação

de obras e assessoria em campo, realizadas pelos técnicos da Peabiru TCA, na Tamarutaca (SA)

Fonte: cedidas por Peabiru TCA.

(página seguinte) fig. 19

Exemplo de desenho feito pelos moradores, e desenho da planta tipo 2B, realizada pelo Quadra Arquitetos, para assessoria de construção à moradia em Brás de Pina (RJ). Fonte: SANTOS, 1981 


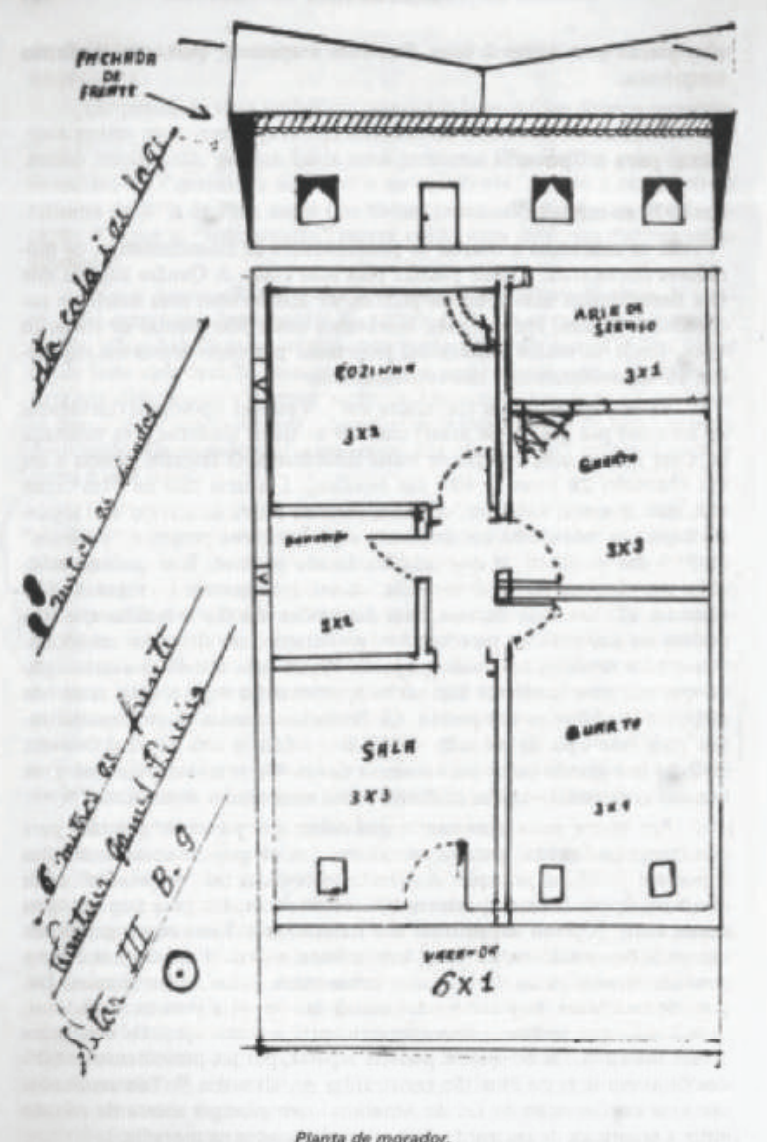

68

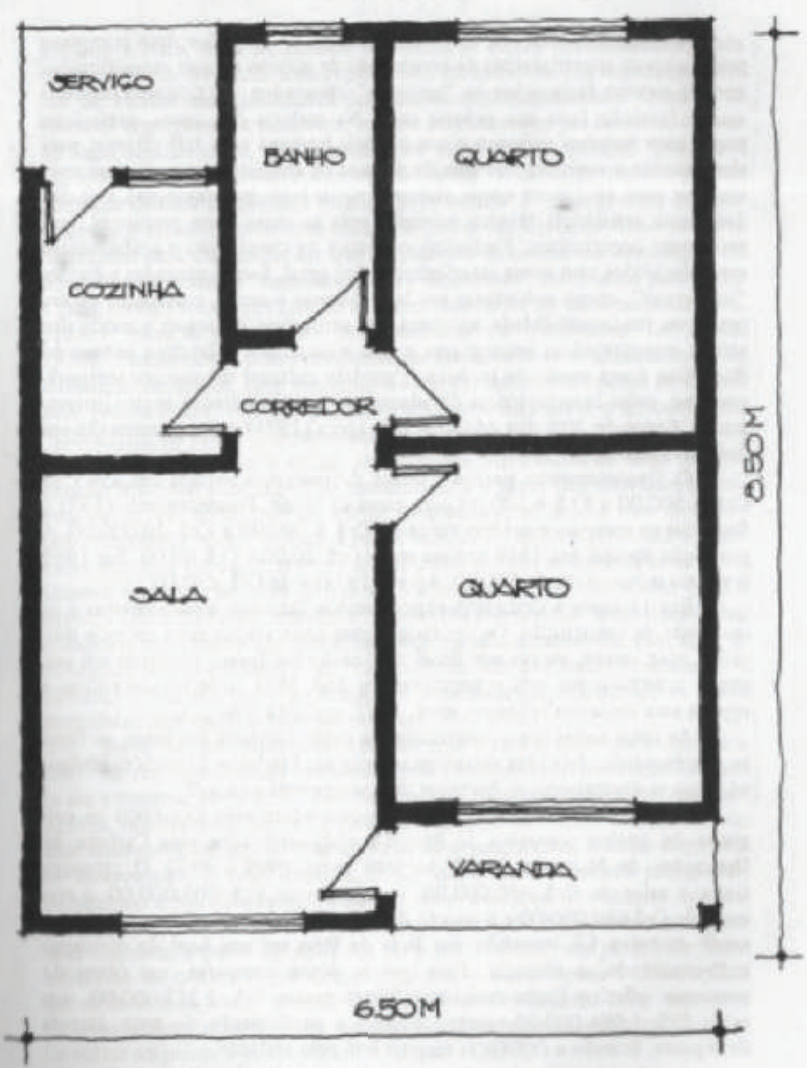

BRIS DE PINA. PLANTA TPO ZS
37. O modelo e dimensão

de lote tinham sido

previamente definidos

pela Prefeitura de

Santo André. Caio

Santo Amore critica

as suas dimensões

pela sua configuração

muito comprida e

estreita, nomeando-os

como "lotes-gaveta".

(SANTO AMORE

e MARQUES, 2015 ,

informação verbal em

entrevista realizada

em I 7/I I/20 I 5, São

Paulo)

38. Entrevista realizada

em I 7/I I/20 I 5, São

Paulo. favela. Foram desenvolvidos pela assessoria técnica, algumas possibilidades de ocupação dos lotes previamente divididos ${ }^{-37}$, de forma a que as habitações se adequassem às necessidades das famílias mas também garantissem qualidade mínima de salubridade, sendo considerados os critérios de insolação e ventilação mínimos, e alguns cálculos estruturais que garantiam a estabilidade da construção.

"O fato de você estar próximo e ir construindo uma relação com as pessoas, era legal. Dava uma outra perspectiva para os projetos, para as obras. (...) Cada projeto tinha o nome da pessoa, o cadastro, e todas as adaptações" (SANTO AMORE e MARQUES, 20 I 5 , informação verbal ${ }^{38}$ ) pedidas pelo morador. A Peabiru desenvolvia os projetos de arquitetura e estrutura, e acompanhava obra, se necessário.
Prática semelhante tinha acontecido em Brás de Pina com a Quadra Arquitetos nos anos 70. Se os moradores encontraram alguma dificuldade em opinar ativamente sobre os planos urbanísticos por serem mais complexos e estarem no plano imaterial, por vezes, de difícil apreensão para quem é leigo nas disciplinas da arquitetura e urbanismo, a sua participação foi mais ativa no momento das ações e decisões com implicações individuais ou familiares (SANTOS, I 98 I). Os moradores foram chamados a participar em colaboração com os projetistas para a definição das suas próprias moradias:

Feitas as mudanças [loteamento, intervenções urbanas e de infraestrutura] e abertas as possibilidade de financiamento, os moradores começaram a pedir 
plantas para suas casas. A Quadra sugeriu que eles desenhassem suas próprias plantas, de acordo com seus desejos e necessidades. Assim, em um mês, recebemos umas 300 plantas de todos os tipos, desde as muito elaboradas, projetadas por engenheiros ou arquitetos, até às absolutamente não-convencionais.

Estas plantas foram traduzidas em um estudo tipológico (incidência de soluções por grupos de áreas) com 13 modelos distintos. Foi montada na Casa Branca ${ }^{[39]}$ uma espécie de stand imobiliário. $\bigcirc$ favorito passou a ser chamado $2 \mathrm{~B}$ (com $\pm 40 \%$ das escolhas). Em uma casa de $47 \mathrm{~m}^{2}$ com sala, dois quartos, banheiro, cozinha, varanda e área de serviço. Em segundo lugar, os moradores continuavam a preferir seus próprios "projetos" ( $\pm 35 \%$ das escolhas), o que foi considerado positivo. (SANTOS, 1981, pg 67)

É possível compreendermos a participação ativa e totalmente consciente das populações nos casos de decisões individuais ou familiares por comparação com um certo afastamento como o relatado por Carlos Nelson, nas discussões sobre planos e projetos urbanos ou infra estruturais e de uso ou impacto coletivo. Para que tal apropriação aconteça, é necessária uma mobilização e engajamento social e político por parte da população. Algumas das práticas que aqui apresentamos, problematizam tanto a participação como se dá, mas acima de tudo, a sua facilitação através de ações que possibilitem a apreensão e compreensão da população para o que se pretende de fato discutir enquanto processo participativo.

A participação social nas urbanizações de favela está inserida na prática de militantes arquitetos, na atuação pública de governos militantes e se consolida e institucionaliza a partir dos organismos e exigências do HBB no Brasil. Até hoje, como no caso do PAC UAP ela é componente obrigatório nos contratos, (PETRAROLLI, 20 I 5 ) ainda que o fato dela ser compulsória, não garanta que, muito recorrentemente, se restrinja à mera legitimação de projetos e obras. Há grandes diferenças entre uma abordagem meramente instrumental da participação, e seu uso com maiores potencialidades dialógicas, democráticas e populares. Essa é uma das críticas de Vera Tângari à forma como o poder público tem implementado urbanização de favelas no Rio de Janeiro nos últimos anos. (TÂNGARI, 20 I6, informação verbal $4^{\circ}$ )

A proposta para a sua efetivação dá-se, na maioria dos casos, através de assembleias públicas, onde o morador é convidado a participar como ouvinte, para eventualmente colocar as suas dúvidas ou opinião, e que podem ter maior ou menor grau de impacto na proposta, dependendo da gestão ou projetista que acompanha o caso. É também

\footnotetext{
39. A Casa Branca

foi uma espécie de

escritório oficial da CO-

DESCO (órgão público

contratante) montado

dentro de Brás de Pina,

que representasse a sua

presença no território

mas também facilitasse

o diálogo entre os diver-

sos agentes do processo

- moradores, associação

e outras lideranças, pro-

jetistas, poder público,

assistentes sociais e

engenheiros da empreit-

eira. (SANTOS, $198 \mathrm{I}$,

pg 65-66)

40. Entrevista realizada

em 23/I I/20I6, Rio de

Janeiro.
} 


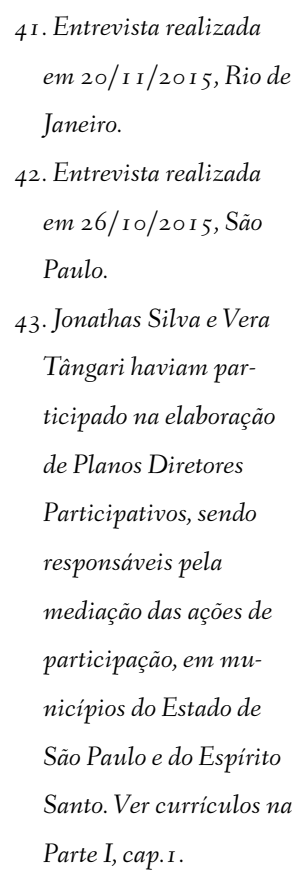

comum o recurso ao DRUP (Diagnóstico Rápido Urbano Participativo), pensado para efetivar a participação ativa dos moradores na etapa de diagnóstico, mas que muitas vezes é realizada em pouco tempo e com pouca profundidade e conhecimento crítico dos principais interessados, os moradores, sobre essa contribuição.

Os sujeitos militantes questionam estes modelos de participação institucionalizados, preferindo a "participação sem hipocrisias" que para Manoel Ribeiro se dá no contato diário e no diálogo direto com a população (RIBEIRO, 201 5, informação verbal $^{4 \mathrm{I}}$ ) como já fomos exemplificando nas práticas de trabalho que desenvolveu na Serrinha (RJ, ı 996-200 I) e em Cantagalo e Pavão-Pavãozinho (RJ, I 999-2003).

No começo dos anos 2000 na experiência do Favela-Bairro, em Cantagalo e Pavão -Pavãozinho, a participação popular não foi facilitada pelo poder público e os modelos aplicados foram questionados pelos projetistas. $\mathrm{Na}$ época Jonathas Silva questionava a sua efetividade para projeto, opinião que foi se alterando com a sua experiência profissional. Naquele época ele achava que a população pouco tinha a contribuir sobre “questões tão técnicas”. Mas após a participação naquele projeto, considerada por ele hoje "super autoritário, em que a gente era proibido de falar com as pessoas", a equipe foi abrindo outros caminhos para estabelecer relações com os moradores. $\mathrm{Na}$ conversa com lideranças e figuras emblemáticas da comunidade, foram "montando a história do lugar, o que era histórico, como surgiram os caminhos, tentando entender a estrutura do lugar, para conseguir propor. Mas não era um processo de diálogo de participação" amplamente estabelecido. (SILVA, 20 I 5 , informação verbal ${ }^{42}$ )

Hoje Jonathas Silva sublinha a importância no processo participativo desde que dentro dos moldes que ele reconhece como participação. Na Rocinha, (RJ, 2007-2008) essa prática foi exaustivamente explorada pela sua equipe.

Já referimos a importância da presença do escritório dentro da comunidade e da equipe de trabalho composta com moradores da favela. Para além disso, desde o momento da participação no Concurso de Ideias (2006) que os projetistas, recorrendo a técnicas já desenvolvidas por Jonathas em outras experiências profissionais ${ }^{43}$, mobilizaram encontros e atividades onde permitiam e procuravam a participação ativa dos diferentes grupos presentes na Rocinha. Para a elaboração do Plano Sócio-Espacial, a Rocinha foi separada por setores, nos quais eram realizadas diferentes reuniões onde eram discutidas as questões de diagnóstico mas também as hipóteses de projeto, com incidência sobre os temas de interesse específico para cada região. A programação da agenda de encontros tinha sido pensada com e para a população em horários e locais que facilitassem o seu acesso. Além disso a agenda foi amplamen- 


\begin{tabular}{|c|c|c|c|c|}
\hline REUNIĀOO & Al & BAIRROS & LOCAL & DATA \\
\hline 0 & TODAS & TODOS & CIEP - BENTO RUBIAO & \\
\hline \multirow[t]{2}{*}{1} & \multirow[t]{2}{*}{ Al 6} & VILA LABORIAUX & \multirow{2}{*}{$\begin{array}{l}\text { ESCOLA DO LABORIAUX } \\
\text { OU OUADRA DE CIMA }\end{array}$} & \multirow[t]{2}{*}{ 25/un } \\
\hline & & VILA CRUZADO & & \\
\hline \multirow[t]{4}{*}{2} & Al1 & BAIRRO BARCELOS & \multirow[t]{4}{*}{ AMABB } & \multirow[t]{4}{*}{ 9/ul } \\
\hline & & CAMPO DO BOLADEIRO & & \\
\hline & & CAMPO DA ESPERANCCA & & \\
\hline & & UPMMR & & \\
\hline \multirow[t]{2}{*}{3} & \multirow[t]{2}{*}{ A/2 } & CIDADE ALTA & \multirow[t]{2}{*}{ SALAO PAROCUIAL } & \multirow[t]{2}{*}{ 23//41 } \\
\hline & & RUA 4 & & \\
\hline 4 & Al 3 & RUA 3 & QUADRA DE CMA & 6/ago \\
\hline 5 & $\mathrm{Al} 3$ & RUA 2 & OUADRA DE CMA & 20lago \\
\hline \multirow[t]{3}{*}{6} & \multirow[t]{3}{*}{ Al 4} & MACEGA & \multirow[t]{3}{*}{ QUADRA DE CMA } & \multirow[t]{3}{*}{$3 / 50 t$} \\
\hline & & MORRO DA ROUPA SUJA & & \\
\hline & & RUA 1 & & \\
\hline \multirow[t]{5}{*}{7} & \multirow[t]{5}{*}{ Al7 } & CACHOPA & \multirow[t]{5}{*}{ OUADRA DA CACHOPA } & \multirow[t]{5}{*}{$17 / \mathrm{set}$} \\
\hline & & CACHOPINHA & & \\
\hline & & ALMIR & & \\
\hline & & CURVADOS & & \\
\hline & & SUL DA RUA DIONEIAA & & \\
\hline 8 & Al7 & VILA VERDE & SULÁO PAROCULAL & Tlout \\
\hline \multirow[t]{2}{*}{9} & \multirow[t]{2}{*}{ Al 8} & VILA UNIAO & \multirow[t]{2}{*}{ QUADRA DE CMA } & \multirow[t]{2}{*}{ 15/out } \\
\hline & & PORTAO VERMELHO & & \\
\hline \multirow[t]{6}{*}{10} & \multirow[t]{6}{*}{ Al 5} & TERREIRAOO & \multirow[t]{6}{*}{ QUADRA DE CMA } & \multirow[t]{6}{*}{ 29/out } \\
\hline & & CAPADO & & \\
\hline & & FAZ DEPRESSA & & \\
\hline & & SETOR 199 & & \\
\hline & & VILA VERMELHA & & \\
\hline & & RUA 1 & & \\
\hline
\end{tabular}

te difundida, só assim Jonathas garante que a participação pode ser efetivada.

Se você quer fazer um trabalho participativo de fato, ou você declara uma agenda com todos os dias e horas que não vão ser definidos por você, têm de ser conversados, (...) Como é que você monta a agenda? Quem é que participa de facto? Como é que você convida as pessoas para participar? Como é que você envolve as pessoas

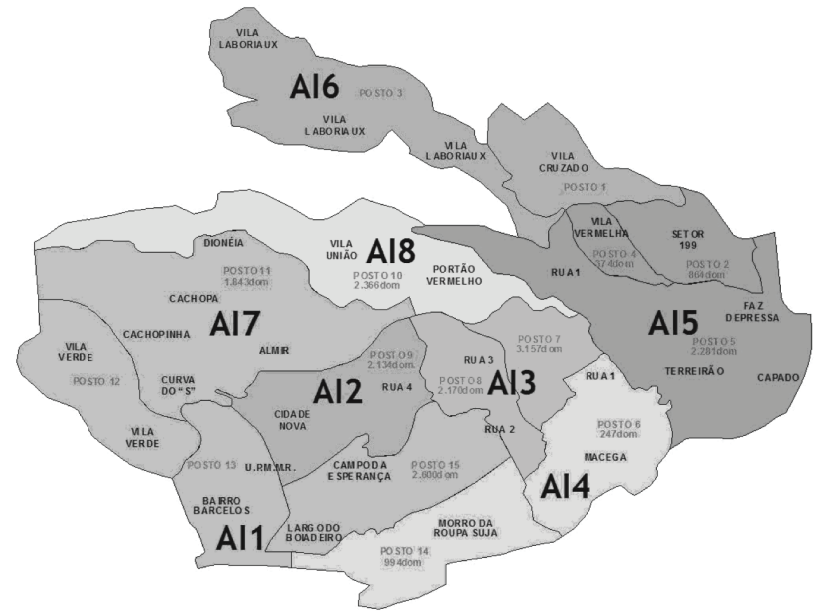

no início, as que vêm com um pé

44. Entrevista realizada atrás, porque são as que fazem mais sentido envolver! Como é que você em 26/10/2015, São Paulo. convence que aquilo vale a pena se envolver? (SILVA, 2015, informação verbal $^{44}$ )

Foram também utilizados os recursos internos já disponíveis na comunidade. A Rocinha possui uma rádio própria que é um importante elemento de comunicação para todos os seus moradores. Para além das comunicações mais informativas sobre o

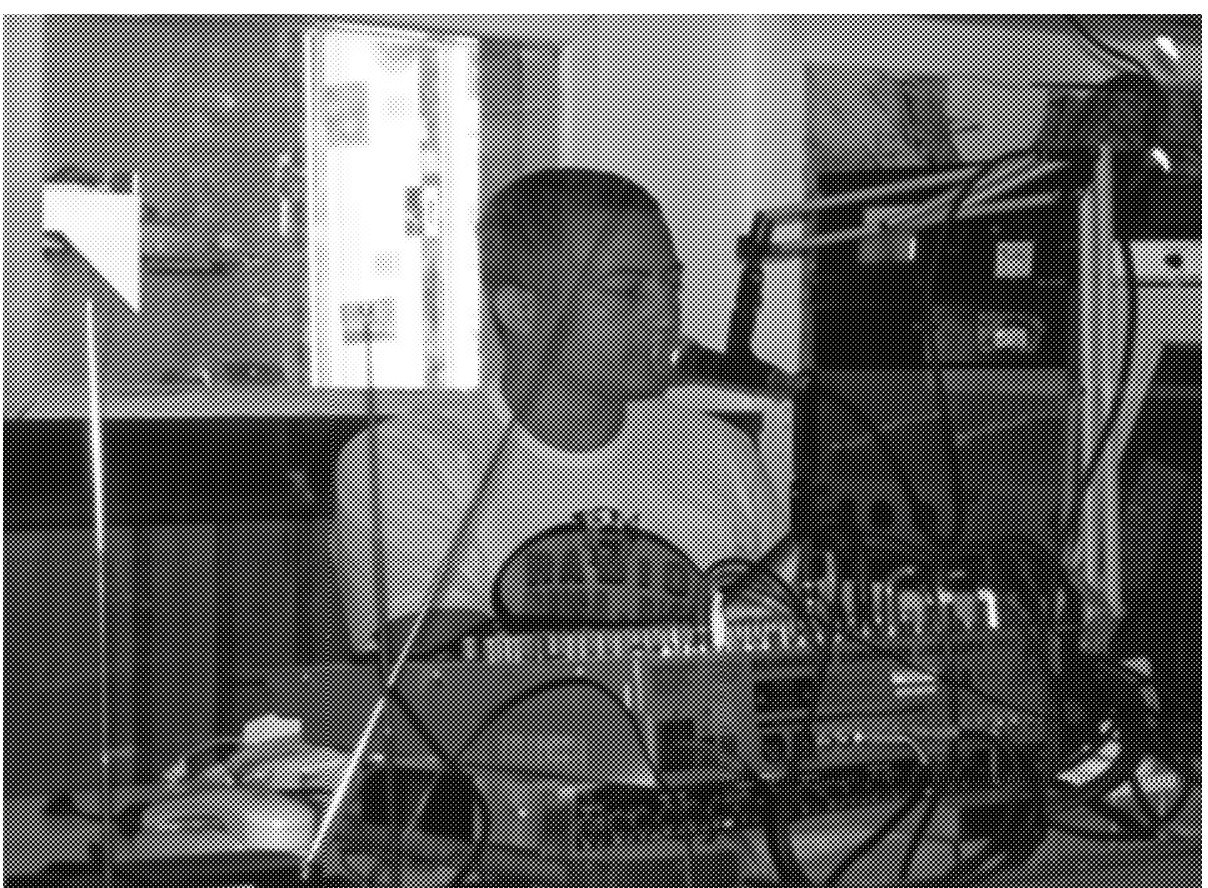

fig. 20 e 21 Agenda de

reuniões com moradores por setor e mapa de setores da Rocinha (RJ). Fonte: cedidas por Jonathas Silva fig. 22 Divulgação do Plano e das reuniões com a população via rádio interna. (Rocinha, RJ). Fonte: cedidas por Jonathas Silva

(página seguinte) fig. $23 \mathrm{e}$ 24 Reuniões e Assembleias para discussão do Plano na Rocinha, (RJ). Fonte: cedidas por Jonathas Silva 

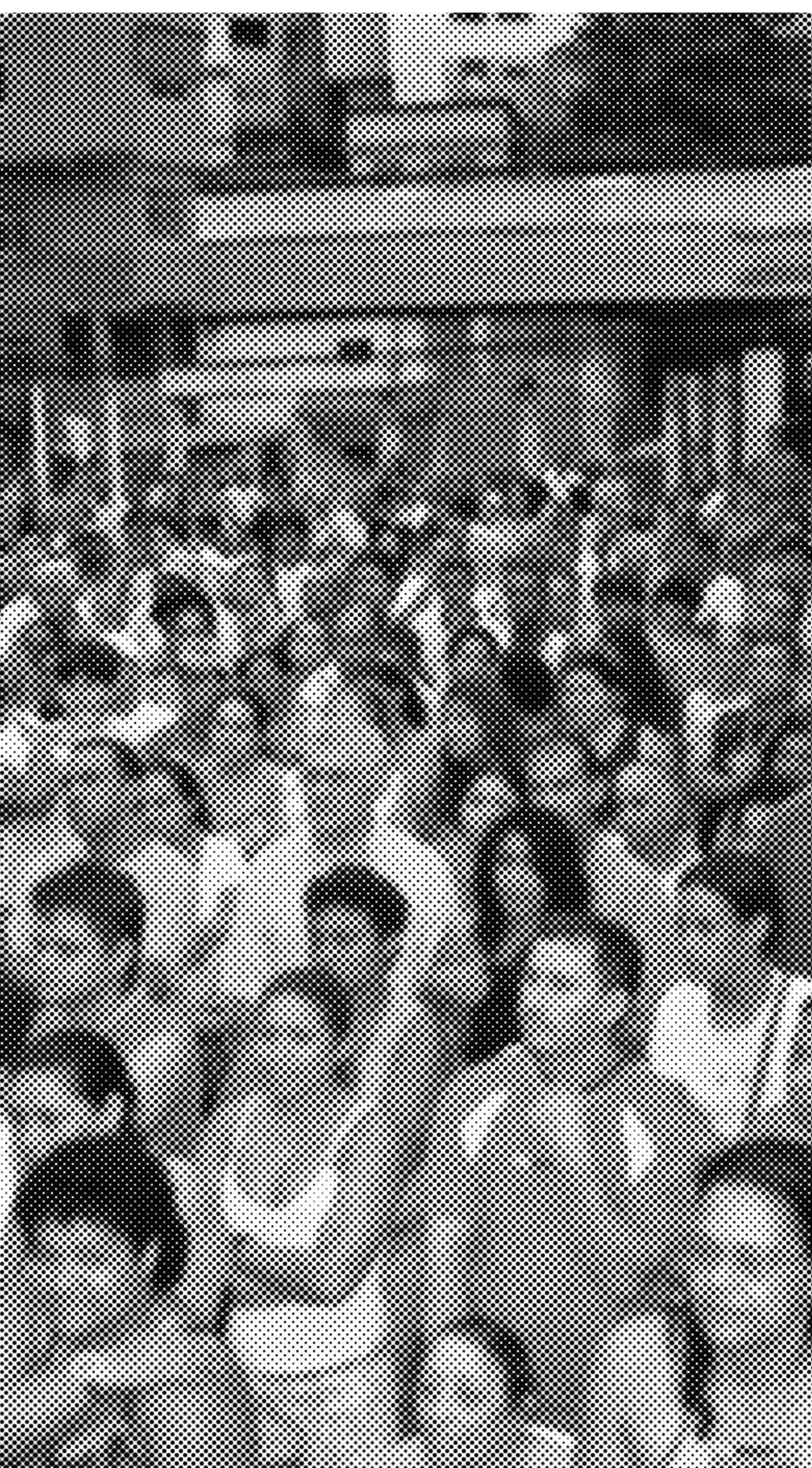

processo, também a agenda de reuniões era divulgada e lembrada por este meio.

Para a equipe técnica composta por moradores com menor grau de especialização em arquitetura e urbanismo, Toledo montou um curso de capacitação, que possibilitou uma aproximação às questões técnicas, mas também históricas e culturais das disciplinas. Se o argumento para a falta de integração de moradores em projetos do bairro, era a falta de capacidade técnica, então "a gente capacitou! Dava aula teórica, dava aula prática e o monitor era o Edigrêt5" (TOLEDO, 20 I 5 , informação verbal ${ }^{46}$ ). Adaptou o curso de urbanismo que dava na UERJ à Rocinha - o Urbanizamentes - acabou por ser alargado a outros membros da comunidade interessados em compreenderem mais sobre a temática.

Esta prática de participação procurou mais do que a legitimação do processo e do projeto, um diálogo emancipado onde 

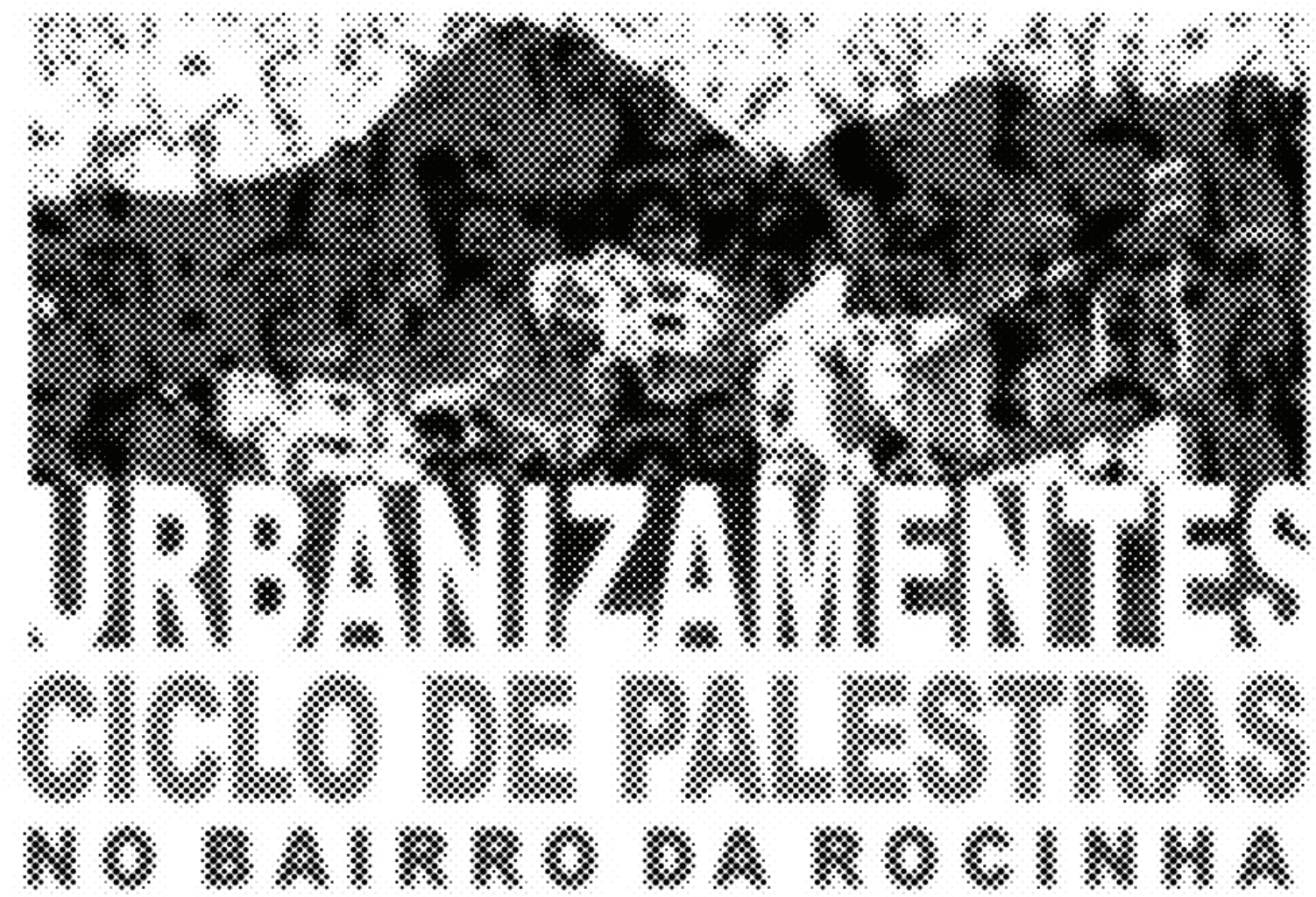

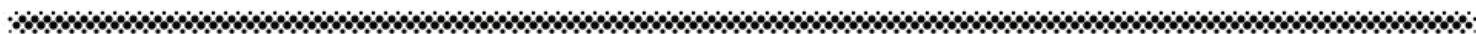

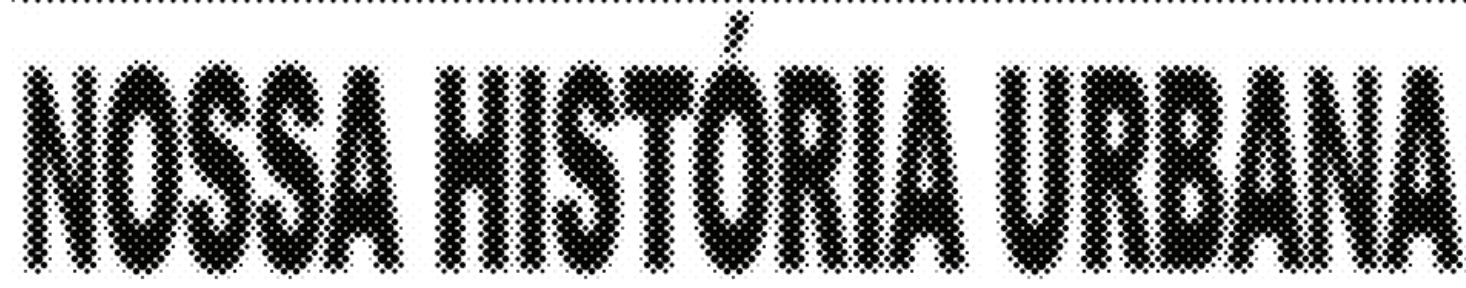

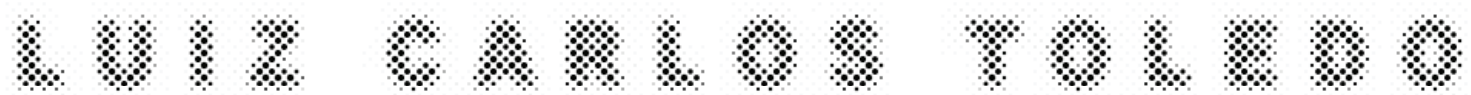

.

\%

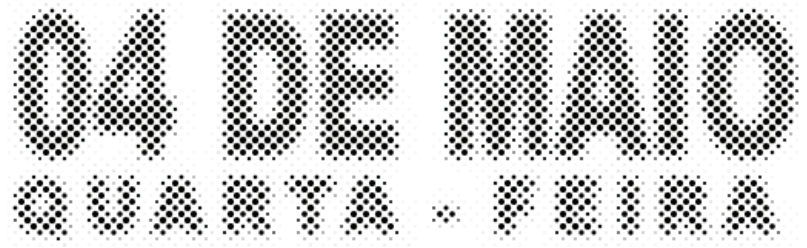

\section{\%}

\% 


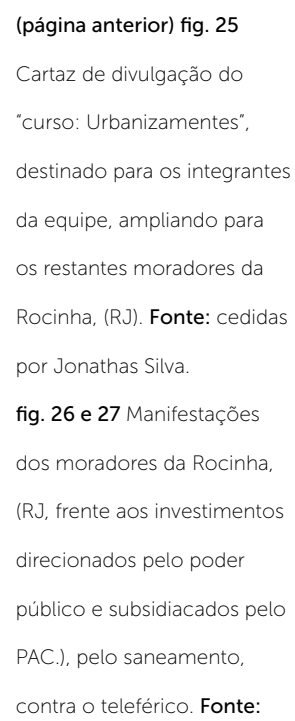

47. Entrevista realizada em 26/10/2015, São

Paulo.

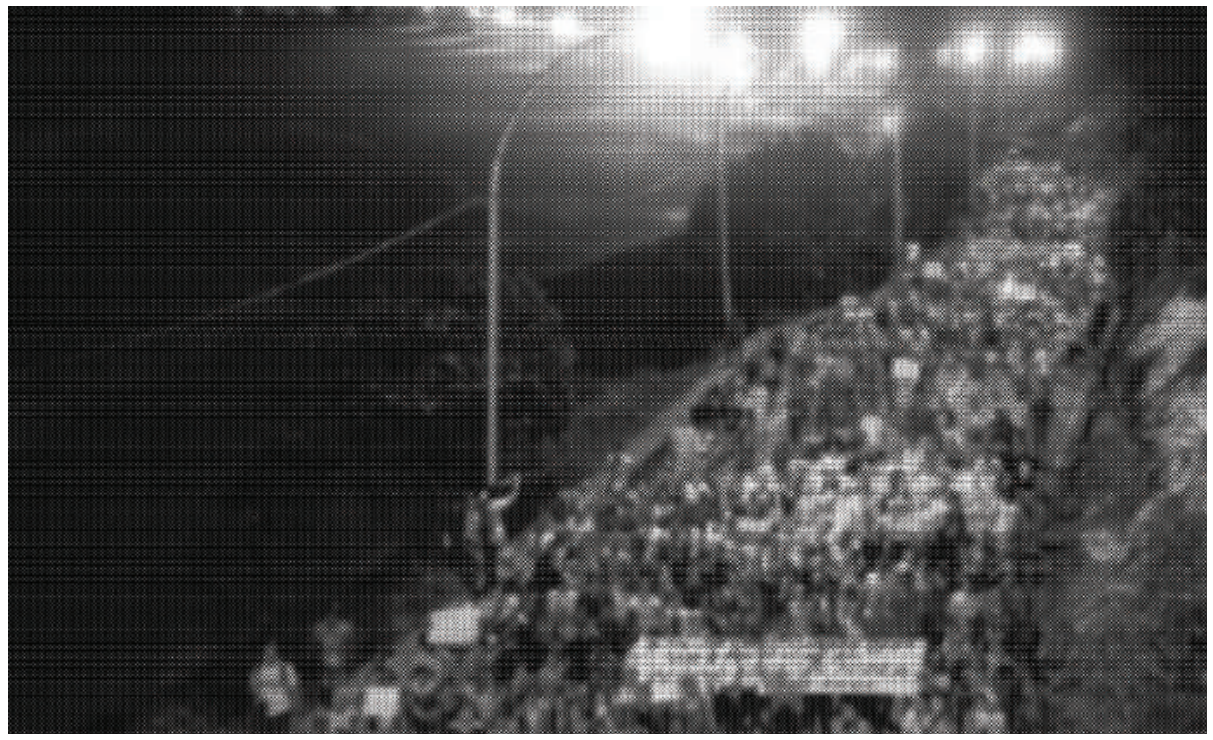

os moradores eram levados para além do mero conhecimento sobre as propostas, à compreensão do seu propósito e impactos da sua intervenção. $\mathrm{O}$ resultado foi a apropriação popular sobre o projeto e suas questões o que levou à reivindicação da atuação pública sobre as decisões tomadas pelos projetistas em colaboração com a comunidade. Disso foram exemplo as manifestações populares contra a implementação de um teleférico na Rocinha, e outras medidas tomadas pelo poder público em meio aos investimentos realizados na cidade para receber os eventos esportivos internacionais, a Copa Mundial de Futebol 20 I 4 e os Jogos Olímpicos 20 I 6. Em vez disso, a população mobilizada reivindicava a implementação do prometido saneamento básico, não concluído até hoje. (SILVA, 20 I 5 , informação verbal ${ }^{47}$ )

A prática de uma participação emancipada é uma das principais preocupações nos trabalhos de assessorias técnicas assumidamente politizadas como a Usina e a Peabiru. A Usina trabalha em muitos processos mobilizados pelos próprios movimentos sociais com histórico de participação política. A assessoria disponibiliza os seus recursos técnicos multidisciplinares para o acesso dos movimentos às informações mais técnicas. Na sua entrevista, Heloisa relembra a sua atuação dentro da Usina e reconhece a dificuldade das discussões de "igual para igual" com os moradores, na maioria das vezes, dotados de pouca

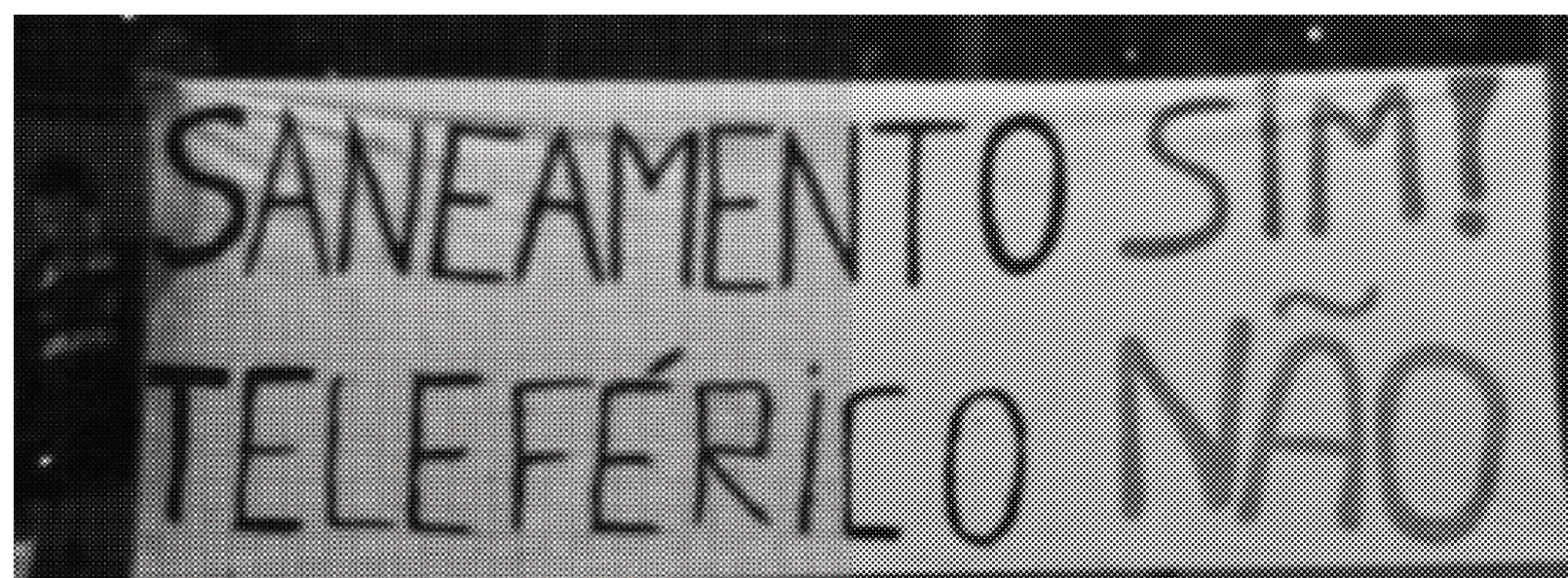


capacitação técnica. No entanto, ela sabe que esse é o desafio da participação, que os interlocutores compreendam o assunto sejam capazes de contribuir para o mesmo conscientemente. (REZENDE, $20 \mathrm{I} 6$, informação verbal ${ }^{4^{8}}$ )

Nesse sentido, a Peabiru tem explorado diferentes práticas de participação popular em processos de urbanização de favelas. $\mathrm{O}$ momento de reconhecimento do território e levantamento casa-a-casa que desenvolvem já demonstra o interesse que a assessoria tem pelas particularidades físicas e sociais de cada favela ${ }^{49}$. Mais do que na participação (no sentido em que habitualmente o termo é utilizado) os arquitetos entrevistados da Peabiru acreditam no compartilhamento de ferramentas e instrumentos e na acessibilidade a informações inteligíveis que possibilitem a compreensão sobre as decisões técnicas tomadas pelos projetistas. (SANTO AMORE e MARQUES, 20 I 5 , informação verbal ${ }^{5 \circ}$ )

No Batistini (SBC, 20 I 4-20 I 6), processo em que foi facilitada, pela Secretaria de Habitação de São Bernardo do Campo (SEHAB PMSBC), uma certa autonomia de gestão do levantamento e projeto, a Peabiru organizou oficinas comunitárias para discutir assuntos críticos no processo de urbanização de favelas, e no caso específico, sobre o Batistini. Realizaram-se Oficinas sobre os Rios e cursos de água, à luz da temática ambiental, outra sobre Espaços Públicos, onde se proporcionou um diálogo sobre os espaços já existentes, a sua utilização e reutilização, a necessidade de criação de outros espaços, e por fim, Oficinas sobre Urbanização. Nestas os participantes eram levados a atuar sobre um território fictício, recriado através de uma maquete, com algumas características definidas, habituais em assentamentos precários, descobrindo as condicionantes técnicas existentes no processo de urbanização, como por exemplo: a necessidade de remoção por risco, proteção
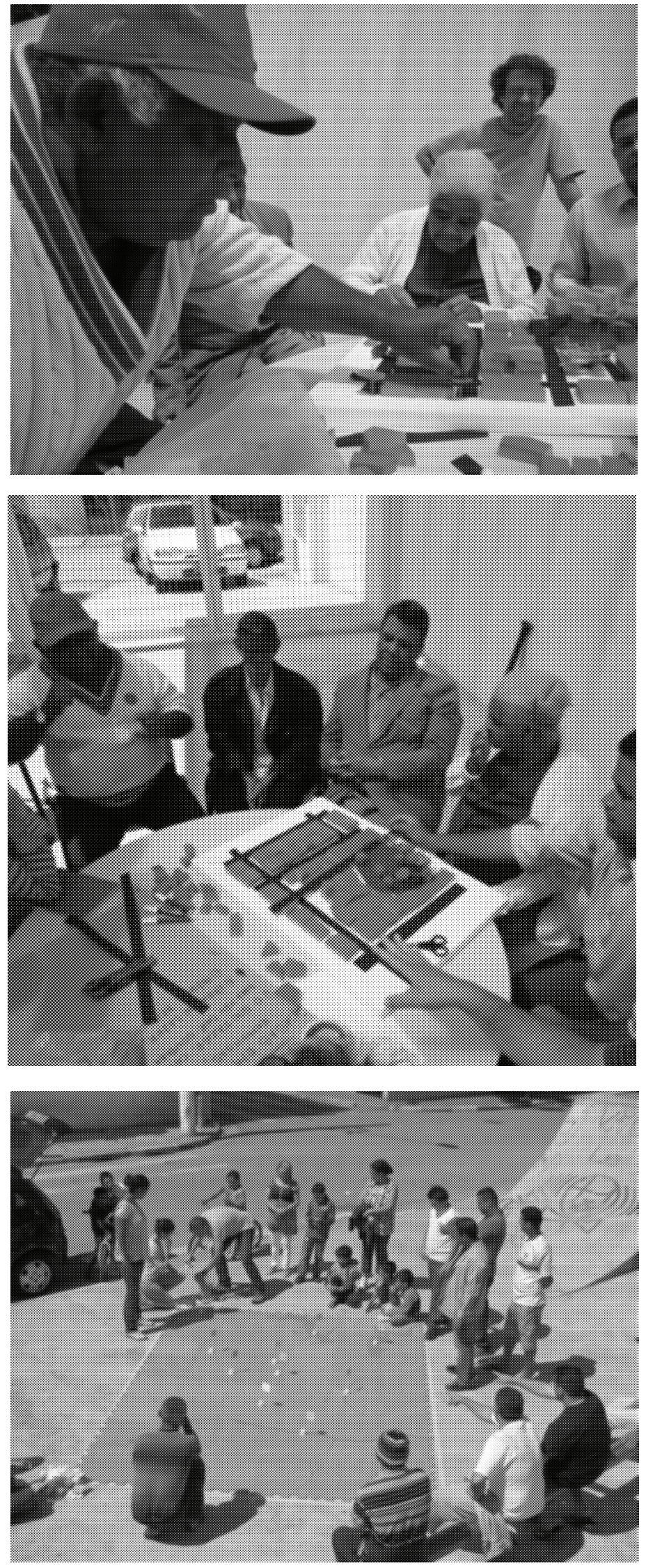


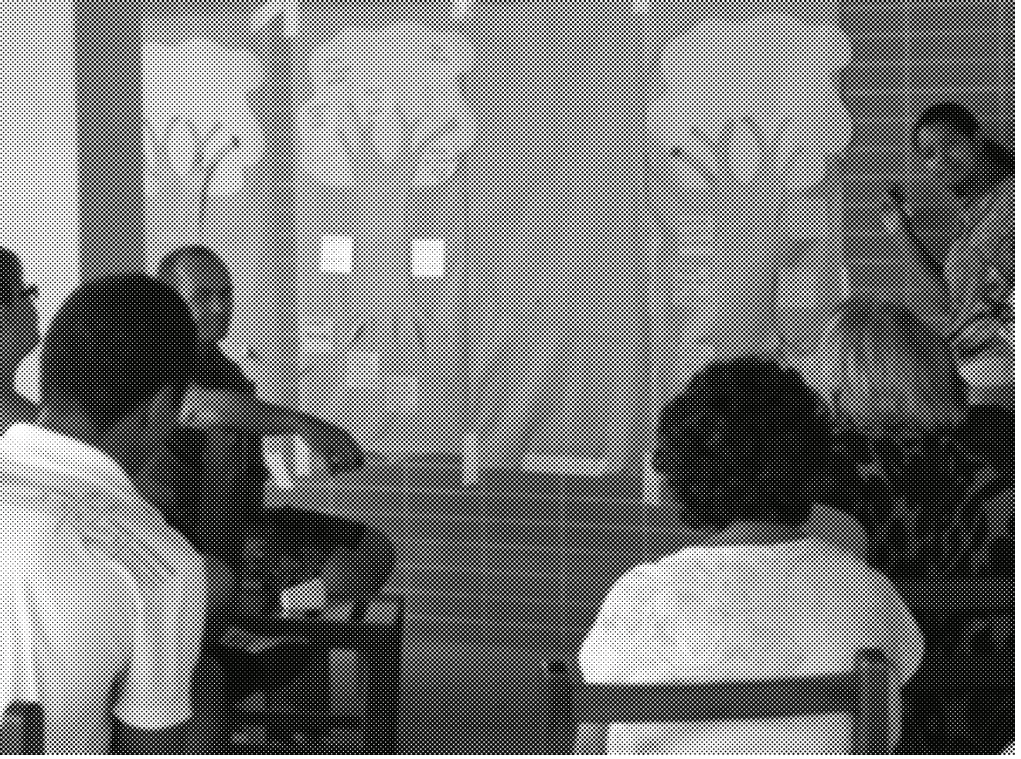

48. Entrevista realizada em I 7/Io/2016, São Paulo.

49. Sobre a metodologia de levantamento de precariedades que a Peabiru tem desenvolvido - o IPHAB -falaremos na Prática: Globalidades \&

\section{Particularidades.}

50. Entrevista realizada em I7/I I/2015, São Paulo. 5I. Idem

(página anterior) fig. 28, 29 e 30, (nesta página, topo) fig 31 e 32 Oficinas realizadas pela Peabiru com os moradores do Batistini (SBC). Fonte: cedidas pela Peabiru TCA.

fig. 33 Plantões de atendimento às familias do Batistini (SBC). Fonte: cedidas pela Peabiru TCA ambiental ou precariedade, a dificuldade de realocação em territórios já ocupados, a distribuição entre espaço público e privado, entre outros aspetos. (SANTO AMORE e MARQUES, 20 I 5, informação verbal ${ }^{5}$ )

Para além destas práticas, a Peabiru procura disponibilizar plantões de atendimento individual a cada família, para esclarecimento de dúvidas nas urbanizações de favelas que desenvolve. Isso implica a intermediação e disponibilidade do organismo público promotor da ação, o que tem sido possível nas últimas experiências realizadas com a (SEHAB PMSBC), no Capelinha e Batistini.

\section{PRÁTICA: COMUNICAÇÃO ACESSÍVEL}

A participação emancipada só é possível ou é facilitada com o recurso a técnicas acessíveis, inteligíveis e apropriáveis pelos interlocutores. A população em geral, sem conhecimento técnico específico, muitas vezes tem dificuldade na utilização e leitura de mapas ou representações técnicas e bidimensionais, como plantas, cortes, desenhos de fachadas ou detalhamento.

Segundo a pesquisa realizada com os sujeitos aqui entrevistados, para possibilitar a compreensão das leituras e propostas, os sujeitos militantes recorrem nas suas

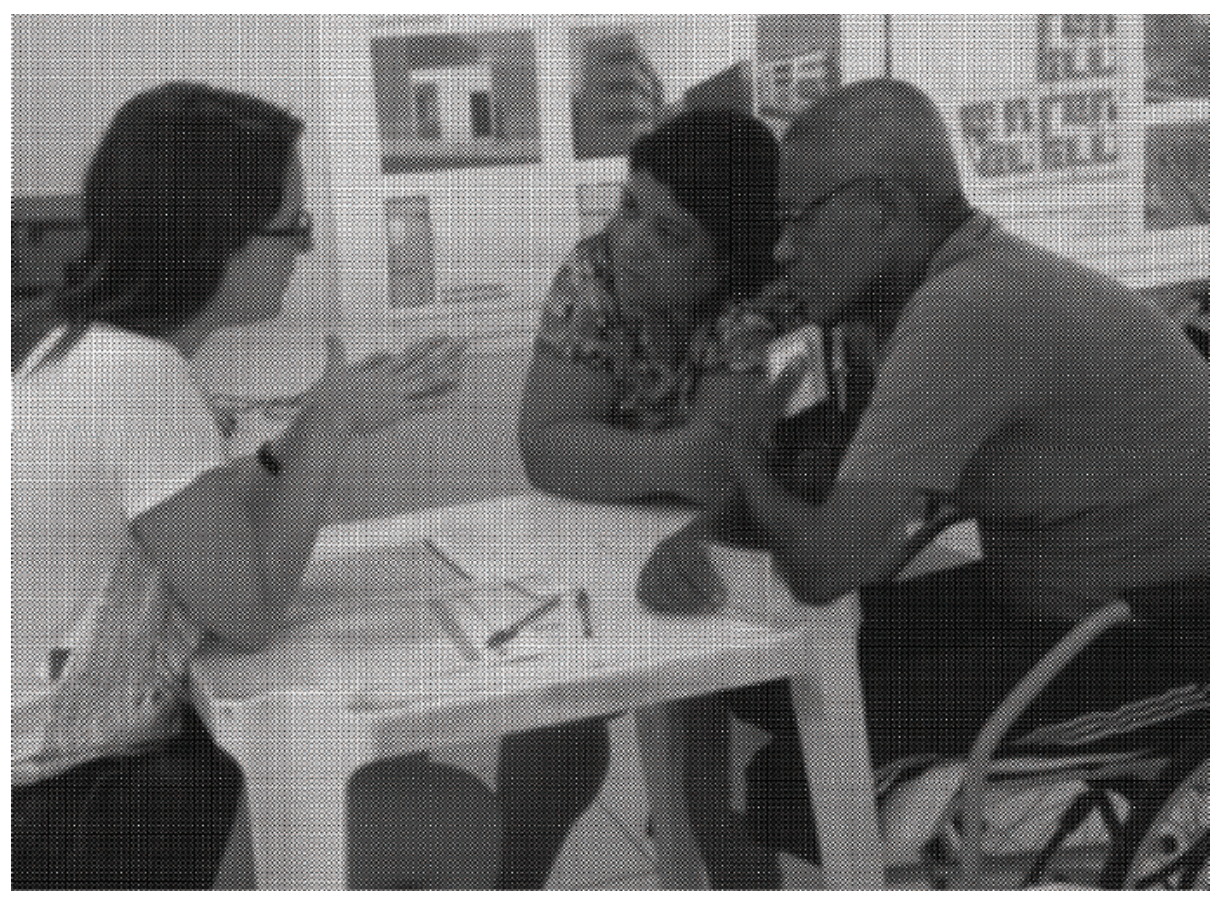


experiências, a técnicas específicas de localização, capacitação ou comunicação mais adequada para olhares menos treinados.

$\mathrm{Na}$ Rocinha (RJ, 2007-2008), Toledo (201 5 , informação verbal ${ }^{52}$ ) relata a prática utilizada em diagnóstico para o levantamento de percursos realizados dentro da comunidade. Sobre uma grande tela onde aparecia a projeção da fotografia aérea da Rocinha, os moradores foram convidados a identificar a sua moradia e os caminhos que percorriam a partir dela. Toledo conta que o primeiro teve alguma dificuldade em se localizar, mas que a partir dele, os restantes encontraram facilmente os pontos e os percursos que mais utilizavam na favela.

Também na Rocinha, antes ainda da contratação pela EMOP (Empresa Metropolitana de Obras Públicas do Estado do Rio de Janeiro) e nas vésperas de entrega da proposta de concurso, Toledo instigou Jonathas Silva, seu colega de equipe, a mobilizar uma atividade participativa para ouvir a opinião dos moradores sobre as propostas que os projetistas haviam pensado. Esse encontro, segundo o depoimento de Toledo, definiria, ou não, a sua participação no concurso. Para a atividade foi construída uma maquete para que facilmente pudessem ser reconhecidos os lugares e localizadas e compreendidas as propostas que seguiriam para concurso.

Daí o Toledo quis fazer uma reunião participativa na favela (...). A gente foi para a reunião, fizemos a maquete

$\begin{array}{lc}\text { do lugar para conseguir mostrar para } & \text { 52. Entrevista realizada } \\ \text { as pessoas, qual era a questão ali... e } & \text { em 23/II/20I5, Rio de } \\ \text { daí levantaram uma série de questões } & \text { Janeiro. } \\ \text { que a gente não tinha nem pensado. } & \text { 53. Entrevista realizada } \\ \text { (SILVA, 2015, informação verbal(53) } & \text { em 26/I0/20I5, São } \\ & \text { Paulo. } \\ \text { As propostas preliminares foram, na sua } & \text { 54. Entrevista realizada } \\ \text { em 23/II/20I5, Rio de } \\ \text { Joria, validadas, mas alguns moradores }\end{array}$
questionaram os projetistas sobre a existência e resolução de possibilidades de estacionamento dentro da comunidade. Esta observação obrigou-os, por um lado a desconstruir paradigmas colocados sobre a população moradora em favelas, e por outro, a repensar e adequar a proposta antes do prazo final do Concurso, que acabaram por ganhar. (TOLEDO, 2015 , informação verbal54)

A maquete física ou eletrônica por se aproximar da realidade material conhecida, permite leituras e identificações mais simplificadas do impacto das soluções. Também a maquete física foi utilizada pela Peabiru, no Batistini (SBC, 20 I 4-20 I 6), nas suas Oficinas de Urbanização. Dessa vez a maquete foi utilizada não só como instrumento para visualização da proposta, mas como material exploratório de análise sobre as situações que os moradores estariam sujeitos durante o processo de urbanização. As peças, móveis, possibilitaram a exploração das soluções, acompanhadas pelos técnicos da Peabiru e pela introdução de questionamentos sobre as decisões e o impacto de determinadas soluções. 

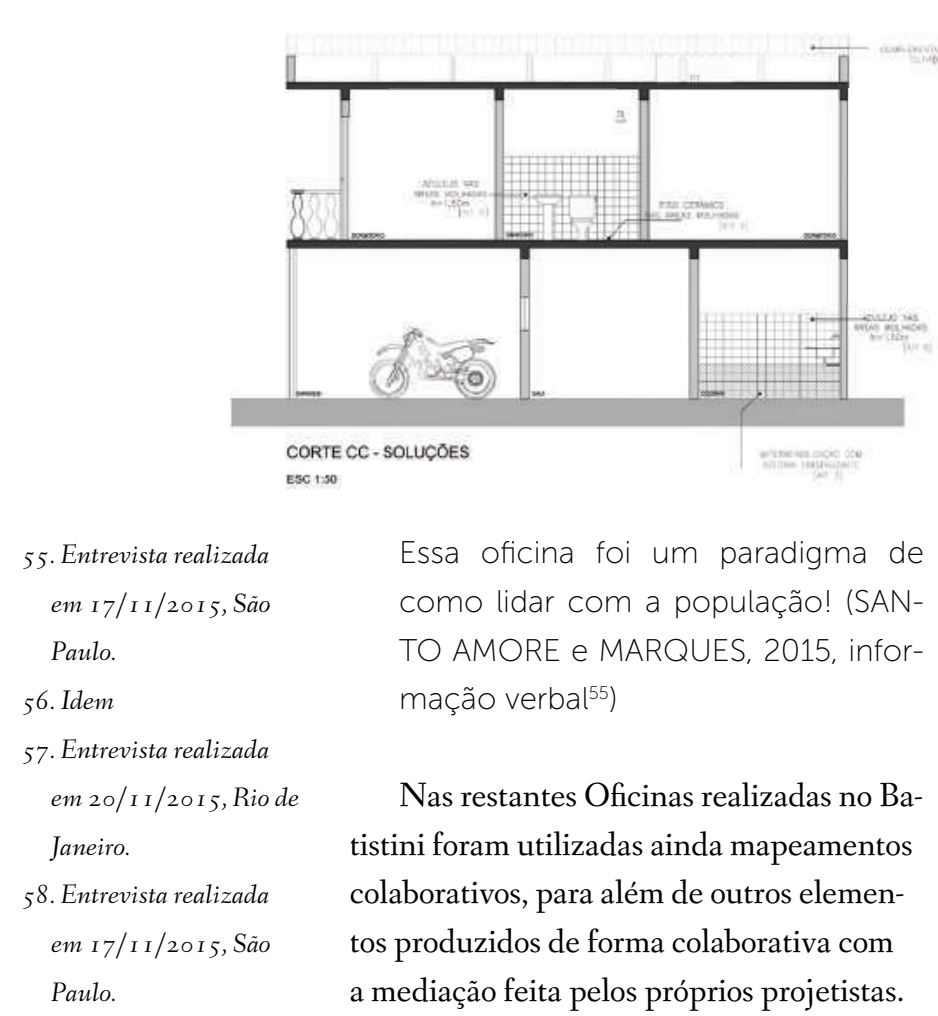

Essa oficina foi um paradigma de como lidar com a população! (SANTO AMORE e MARQUES, 2015, informação verbal ${ }^{55}$ )

Nas restantes Oficinas realizadas no Batistini foram utilizadas ainda mapeamentos colaborativos, para além de outros elementos produzidos de forma colaborativa com a mediação feita pelos próprios projetistas. Assim, foram sistematizadas diretrizes de projeto que fossem de encontro à população moradora e principal utilizadora / beneficiadora das intervenções urbanas a propor. (SANTO AMORE e MARQUES, 2015, informação verbal ${ }^{5}$ )

Muitas vezes a adequação das representações, surge apenas pelo interesse do arquiteto em querer facilitar o diálogo entre ele mesmo e os moradores da favela. $\mathrm{Na}$ Serrinha (RJ, I 996-200 I), Manoel Ribeiro compreendendo a complexidade para o entendimento das soluções que havia proposto, recorreu ao uso da perspectiva para melhor esclarecer sobre as suas intervenções. Uma das imagens foi pintada como mural na favela. (RIBEIRO, 20 I 5 , informação verbal ${ }^{57}$ )

Também para se aproximarem das realidades locais, a Peabiru começou a introduzir elementos referência da cultura popular presente na própria comunidade, como balaústres em varandas, nas apresentações para a população das soluções habitacionais, evolutivas e de melhorias.

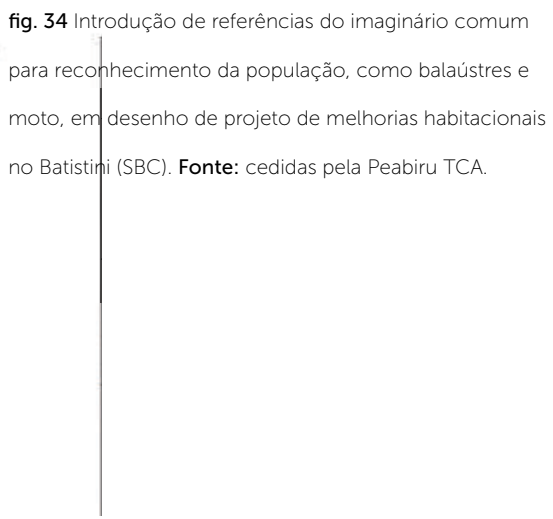

Ela [a moradia] é para o cara fazer o que quiser. Há zero de vaidade de arquitetura associada. (SANTO AMORE e MARQUES, 2015, informação verbal $\left.{ }^{58}\right)$

Tanto a aproximação pelos signos e referências comuns e acessíveis, quanto a PRÁTICA DA IMERSÃo como aqui já abordamos, são facilitadores do acesso ao diálogo. E Manoel Ribeiro lembra, na sua entrevista a importância do diálogo para este ou qualquer outro processo de arquitetura e urbanismo.

A grande dificuldade do diagnóstico é saber fazer as perguntas certas. (...) Porque você pode ter um noção do que seja um diagnóstico, fazer as perguntas adequadas a essa noção, e na realidade, ela não corresponder às necessidades do cliente.(...) quando você se junta para fazer uma casa, de uma certa maneira, você reúne a família, conversa um pouco, fica sabendo quais são as manias, quais são os horários, os fluxos, como é que reúne aqui ou não reúne, (...) e a partir dessas práticas familiares, você já tem um programa de necessidades, (...) você organiza o espaço em função desse entendimento de como é que funciona aquela família. (...) Aí é que está a grande dificuldade... 
você ter a sensibilidade de perceber como é que as coisas se dão, as relações se estabelecem, os fluxos se dão, os pontos de encontro e de divergências... (RIBEIRO, 2015, informação verbal ${ }^{59}$ )

Nesse aspecto, também é comum encontramos estes sujeitos como promotores de diálogo não só com e entre moradores mas também com outros atores do processo que abordaremos adiante na Prática: MEDIADOR.

Mais dos que as técnicas de representação utilizadas, ou para além delas, os sujeitos militantes acreditam numa postura acessível, que pode ser facilitada por esta ou aquela ferramenta. $\mathrm{O}$ fundamental é estar disponível para a comunicação, inclusive para aprender no processo e com todos os atores. Como nos lembra Heloisa, os moradores detém conhecimentos sobre a favela, o lugar e suas vidas, apenas acessíveis na disponibilidade de conversar, ouvir e para também ser ouvido. (REZENDE, 20 I6, informação verbal ${ }^{6 \circ}$ )

\section{PRÁTICA: A “MÃO LEVE” 61}

Desta disponibilidade e sensibilidade nas práticas dos sujeitos militantes, resultam propostas e representações também elas sensíveis e que procuram transmitir intervenções aproximadas às necessidades apreendidas no processo, e com ideias que pretendem a aproximação a ações menos impositivas e apenas com o impacto necessário sobre o território.

Claro que avaliar este impacto e o grau de imposição ou adequação das propostas, de sujeitos que consideramos ou não militantes em urbanização de favelas, é um procedimento de difícil alcance, pela subjetividade inerente a tal questão. $\mathrm{O}$ que encontramos de comum nestes sujeitos é o reconhecimento do impacto que uma intervenção física pode ter sobre determinado território e seu tecido social, e uma busca constante pelo encontro de soluções colaborativas, conciliadas entre os interesses, e que beneficiem a maioria no sentido da melhoria da qualidade de vida.

Esta prática revela quase uma crítica sobre a formação, conceituação e ação do arquiteto, como comumente é identificado. Carlos Nelson inicia essa crítica refletindo sobre a sua formação de cariz modernista, tecnocrática e afastada da realidade que os jovens arquitetos se sentiam motivados a intervir.

\footnotetext{
A faculdade me decepcionou muito depressa. Naquele tempo o que se ensinava era o racionalismo inconteste de pensar corretamente na Arquitetura, já que representava o coroamento de um processo histórico evolutivo. $\bigcirc$ arquiteto-tipo deveria ser um profissional liberal,
}

\footnotetext{
59. Entrevista realizada em 20/I I/2015, Rio de Janeiro.

6o. Entrevista realizada em I7/Iо/2016, São Paulo.

6. Esta denominação é

resultado de uma das conversas informais que tivemos com Vera Tângari em Junho de 2016 , explicando o objeto desta pesquisa. Só posteriormente (a essa conversa) integramos Vera como um dos sujeitos a entrevistar e complementar o grupo de sujeitos militantes em urbanização de favelas.
} 


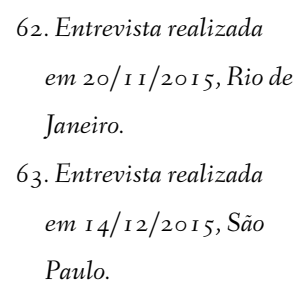

64. Ver nota 61. individualista e omnipotente nas suas

intuições. Éramos formados tendo como meta a genialidade, com toda a carga de expectativas e frustrações decorrentes. (...) O problema é que havia aí uma confusão entre grupo profissional, vocação, formação, indivíduos, pessoas, nacionalismo, internacionalismo, que acabava por nos deixar querendo o impossivel frente aos instrumentos que nos apresentavam e ao caráter que tentavam nos imprimir. Éramos os consolidadores de utopias que não sabiam enfrentar as práticas mais elementares do campo de ação que pretendiam empolgar e orientar. (...) (SANTOS, 1981, pg 37-38)

Ora, quando falamos destas práticas de urbanização de favelas, realizadas por estes, que consideramos sujeitos militantes, falamos de outra forma de olhar e agir sobre o espaço. Reconhecemos nos seus discursos diferentes posicionamentos ou atitudes frente às pré-existências físicas e histórias de vida, e verificamos nas suas propostas e representações gráficas são traços reveladores da importância das características materiais e imateriais já existentes nestes lugares e propostas que se aproximam da reforma do tecido urbano, levando em consideração as pré-existências, e a adequação quase detalhada sobre um tão diversificado espaço. Manoel Ribeiro compara a urbanização em favelas como uma prática de 'alta-costura' "com todos os trocadilhos que você possa imaginar, é a costura política, sob-medida, feita no corpo, alta-costura mesmo" (RIBEIRO, 20 I 5 , informação verbal ${ }^{62}$ ) e Milton Nakamura (20 I 5 , informação verbal ${ }^{63}$ ), parafraseando a pesquisa de Petrarolli (20 I 5 ) admite que esta é uma prática de reforma do território, e como tal, todos os processos deveriam ser desencadeados nessa lógica, desde as leituras territoriais, à forma de contratação e obra.

Em conversa informal com Vera Tângari $^{64}$, numa reflexão sobre este conjunto de sujeitos (no qual também a incluímos), a arquiteta falou-nos como estes projetos sobre favelas revelam uma 'mão leve'. Não podemos afirmar qual a definição exata de Vera para essa expressão. No contexto desta pesquisa, o que entendemos como Prática DA 'MÃo LEVE' trata-se das representações e ações preocupadas, interessadas pelo outro e pelo local, procurando uma atitude quase horizontal e vernacular, no encontro da resolução das necessidades da maioria, e da fuga pelo traço autoral e genial (e porque não, autoritário) comumente associado à prática do arquiteto. A 'mão leve' revela-se nas atitudes e no desenho.

É Jonathas Silva que nos lembra do quanto o desenho pode ser intimidador ou autoritário, e que esse é um instrumento a ser usado com cuidado, sobretudo em processos que se pretendem participativos. 


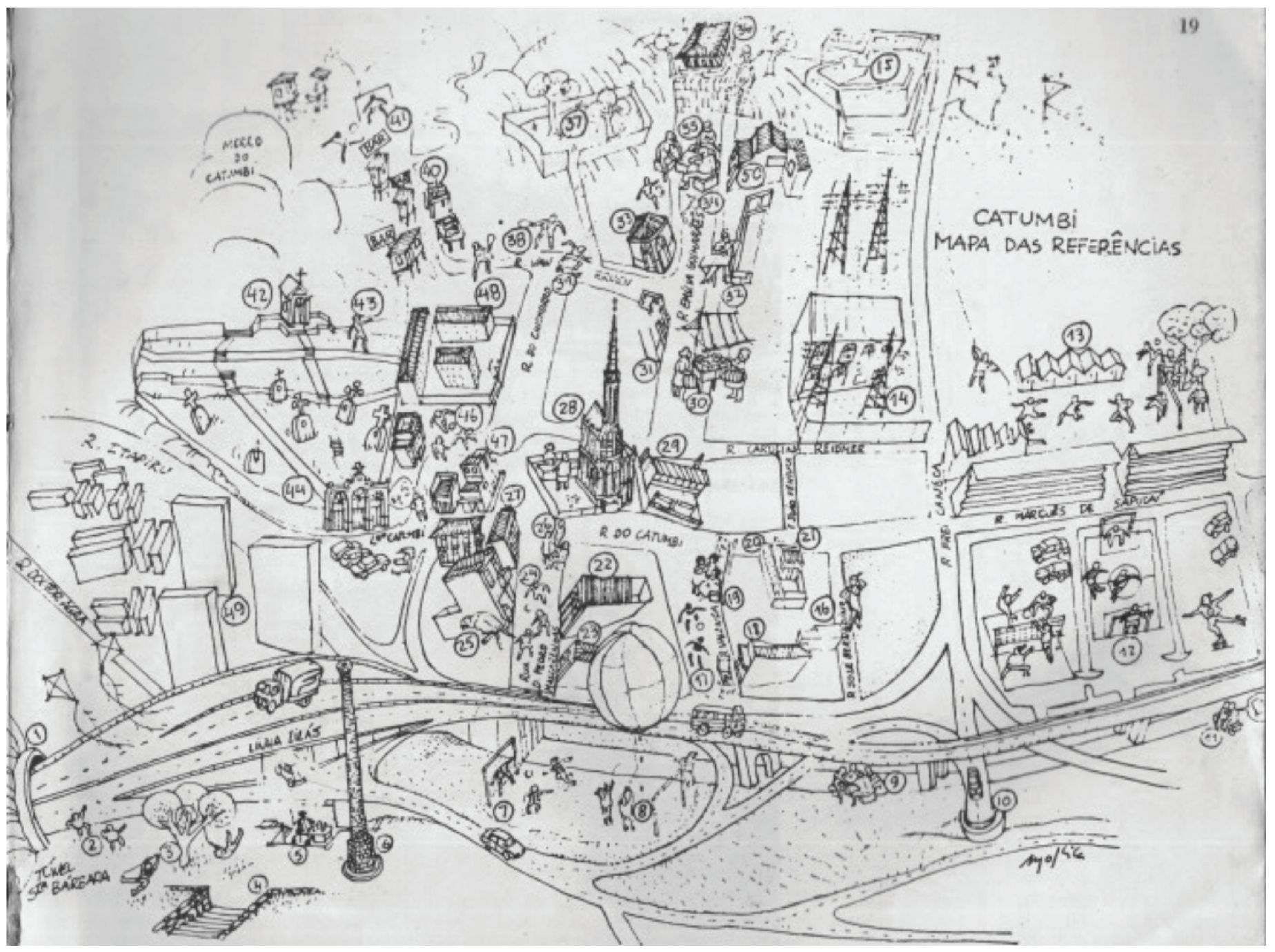

Se você entra com o teu arsenal de desenhos antes do diálogo, você quebra qualquer possibilidade de haver realmente um diálogo. A ferramenta do desenho (...), você tem que tomar um cuidado muito grande, porque ao mesmo tempo que ela pode trazer soluções, e ir para o concreto, porque não adianta ficar só no discurso, na hora que tem que fazer uma obra... mas com as tuas soluções você pode dar um encaminhamento para uma coisa que não é para ser daquele jeito.(...) Eu aprendi isso na experiência. (SILVA, 2015, informação verbal ${ }^{65}$ )
Ao mesmo tempo, Jonathas assume a importância da ferramenta na sua pesquisa projetual, seja qual for o papel que desempenha numa equipe, inclusive como coordenador, papel que assumiu tanto em Cantagalo e Pavão-Pavãozinho (RJ, I 9992003), como na Rocinha (2007-2008), o que pode ser claramente identificado nos desenhos que produz.

Eu preciso desenhar muito para entender qual é o problema. E eu estou falando da questão espacial mesmo. Se você não põe a mão na massa, não faz desenho, não faz análise, e eu estou falando para qualquer escala, se você não põe fig. 35 Mapa de referências do Catumbi, realizado por Carlos Nelson. Nele é evidente um traçado de representação que vai para além da mera dimensão física. Fonte: SANTOS, 1985

65. Entrevista realizada em 26/10/2015, São Paulo.

66. Entrevista realizada em 26/10/2015, São

Paulo. 


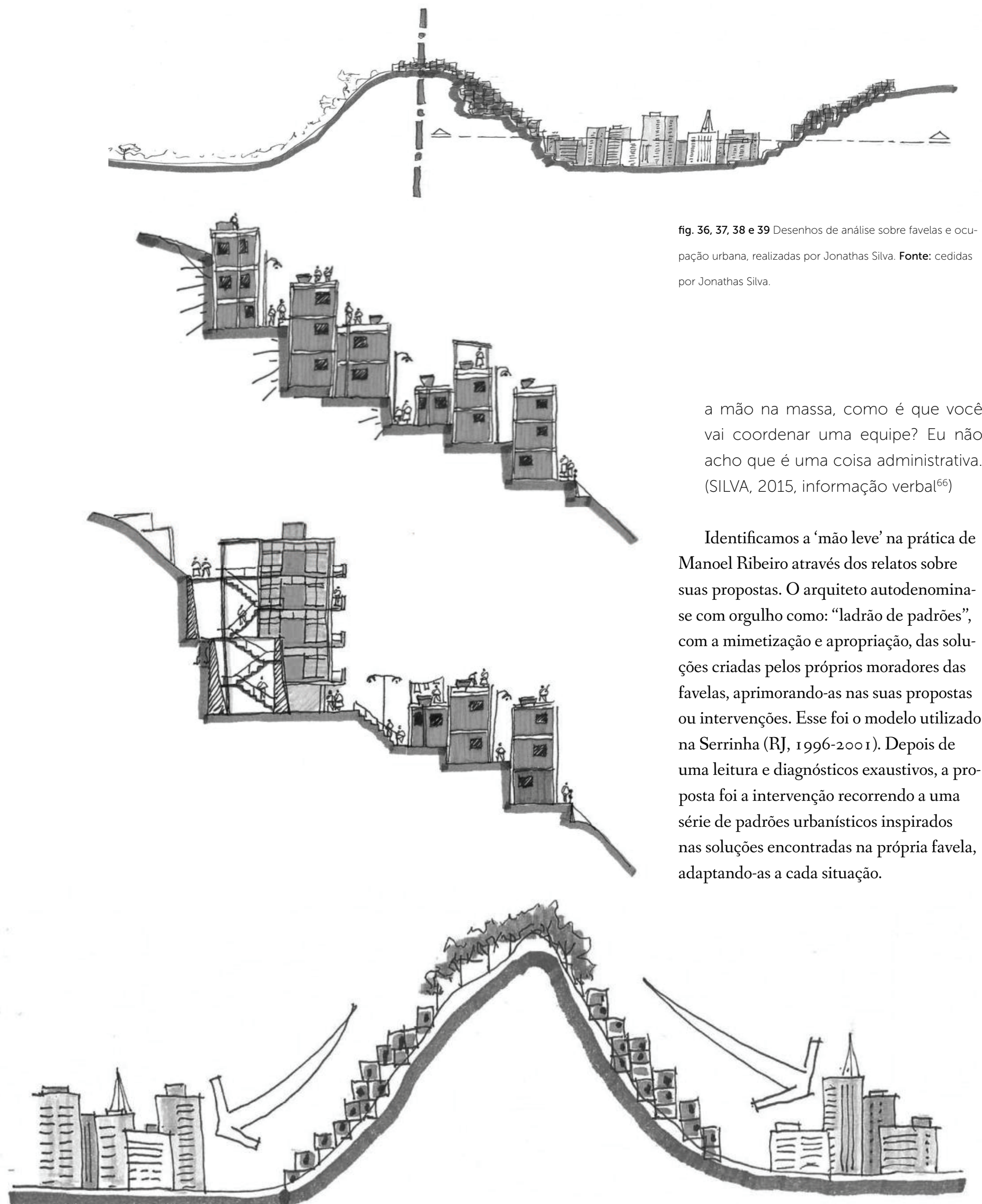


Na parte mais plana, as casas são voltadas para a rua. Quando começa a ficar inclinado, as casas são voltadas para o panorama, são mais estreitinhas, são as casas-vagão, que o único problema que tinham [era a falta de privacidade, pelas janelas serem baixas]. Então nos projetos que eu fiz lá, eu elevei um pouco [a calçada/acesso às casas] e criei uma escadinha individual para cada casa, mas dentro dos padrões que eles criaram, porque eu sou um ladrão de padrões! Com muito orgulho!

Isso é o que eu falei de padrão geral de urbanização: caminhos a meia encosta, com uma canaleta, vários para interromper as águas, para limitar a velocidade e várias descidas de água, paralelas à descida de pedestre, às vezes com drenagem superficial, porque quando é um trecho estreito, já vira na canaleta, ou desce para o vale para evitar grande [acumulação] de volumes. (RIBEIRO, 2015, informação verbal ${ }^{67}$ )

Desta forma, o desenho tendencialmente impositivo, é na verdade, oriundo da própria comunidade, encontrando assim uma identificação mais aproximada à realidade local.

Esta foi também a ideia utilizada em outras propostas suas, como nas participações dos concursos: Concurso Nacional de
Ideias para Urbanização da Rocinha (2006) e Morar Carioca (20 I I).

Para favela de encosta e favela plana eu começo a trabalhar alguns tipos, por exemplo: acessibilidade, pode ser só estrada, pode ser um elevador, pode ser um plano inclinado, pode ser combinar plano inclinado com elevador; internamente, pode ser um padrão Rocinha (olha eu roubando padrões de novo), tem um esquema lá como o Jauregui fez, tem essa outra alternativa, em cimas das estações criar umas lajes de integração, de esporte,... isso aqui é uma espécie de cartilha, né? A água do plano, a água de encosta, esgoto, drenagem, aquele esquema que já te mostrei antes e vai por aí fora. Os piscinões, que usamos em Manaus. A questão do lixo, aí a questão habitacional, isso é Santa Marta, isso é Mangueiral... enfim, plano e encosta, a Serrinha. Plano e encosta como é que se constrói. Pré-fabricado. Os tipos de contenção. Quer dizer, são padrões que você aplica nas situações semelhantes, ou em encosta ou em plano, conforme a situação. Aqui já conceitual de novo, os mecanismos de acompanhamento, como é que se consegue envolver a comunidade no controle social de invasões de construção e por aí afora.
67. Entrevista realizada

em 20/II/2015, Rio de

Janeiro.

68. Idem

69. M_EIA - MINDE-

LO_Escola Internacional de ARTE - espaço

de ensino superior nas áreas das artes e do design incluindo a formação de professores do ensino secundário nas respectivas áreas em Cabo Verde. Para além da formação para professores, o M_EIA disponibiliza o acesso às Licenciaturas em Design de Equipamento, Design de

Comunicação e Artes Visuais, e ao curso de Mestrado Integrado em Arquitectura, com a opção de especialização nas vias de ensino ou profissionalizante.

Apresenta-se como um espaço educativo, laboratorial, e experimental, preparado para o exercicio de investimen tos culturais necessários para o desenvolvimento da cultura como agente 


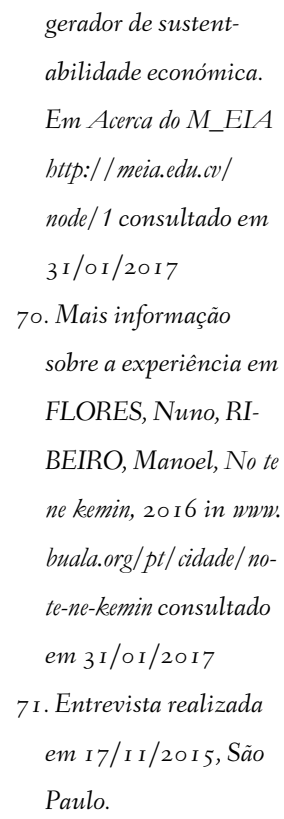

\section{(...) é preciso estabelecer alguns padrões que se replicam e tipologias de problemas semelhantes." (RIBEIRO, 2015, informação verbal ${ }^{68)}$}

Em 2015, Manoel Ribeiro foi professor e palestrante convidado de uma iniciativa em Cabo Verde para alunos de graduação do curso de Arquitetura do M_EIA ${ }^{69}$. No exercício que orientou junto com o professor e arquiteto Nuno Flores, levaram os alunos a reconhecer, propor leituras e intervenções sobre um assentamento precário naquele país. Assim como na Serrinha, Manoel atentou os alunos para as formas de produção e soluções vernaculares, para que as mesmas fossem avaliadas e consideradas em projeto. ${ }^{70}$

Alexandre Marques da Peabiru, afirma que não lhes interessa tanto o resultado, como o processo (SANTO AMORE e MARQUES, 2015 , informação verbal ${ }^{71}$ ). Para a Peabiru o traço autoral é secundário face a processos que se revelem participativos (no sentido que anteriormente colocamos), formadores e transformadores da paisagem e das mentalidades no sentido mais justo e emancipador. A 'mão leve' da assessoria revela-se, a nosso ver, nas propostas habitacionais que, na urbanização de favelas, procuram ir de encontro às necessidades e realidades dos moradores, admitindo e projetando unidades evolutivas, assim como a defesa da intervenção por melhorias habitacionais. No caso das mora- dias evolutivas, admite-se e prevê-se que o morador desenvolva a sua própria habitação, a seu gosto, conforme a sua necessidade e capacidade de investimento. A proposta de inclusão de melhorias habitacionais em urbanização de favelas, não pretende transformar a "cara" da casa dando-lhe qualquer cariz "arquitetônico", mas pretende antes garantir a melhoria da qualidade de vida dos seus moradores, evitando ou resolvendo aspectos construtivos de segurança ou salubridade.

Se a prática da 'mão leve' pode ser mais facilmente identificada em representações gráficas, encontramos também algumas atitudes que procuram reduzir o carácter tendencialmente impositivo e autoritário de intervenções desta natureza. É o caso da técnica de selagem aplicada pela Peabiru no Batistini (SBC, 20 I 4-20 I6). Esta ação, normalmente realizada pelos técnicos da equipe social do poder público, marca, em determinado momento, fisicamente e com um cadastro, cada casa e respectiva família que fará parte do projeto de intervenção, e portanto, hipoteticamente será beneficiário, "congelando" a área. Isso implica que nenhuma modificação ou alteração (nova ocupação, extensão da casa, etc.) será considerada a partir daquele momento. Esta ação é normalmente realizada recorrendo à numeração aplicada com grafitti, nas paredes de cada casa. Para além da caracterização esteticamente pouco agradável, ela se revela uma ação impositiva sobre a vida daquelas 


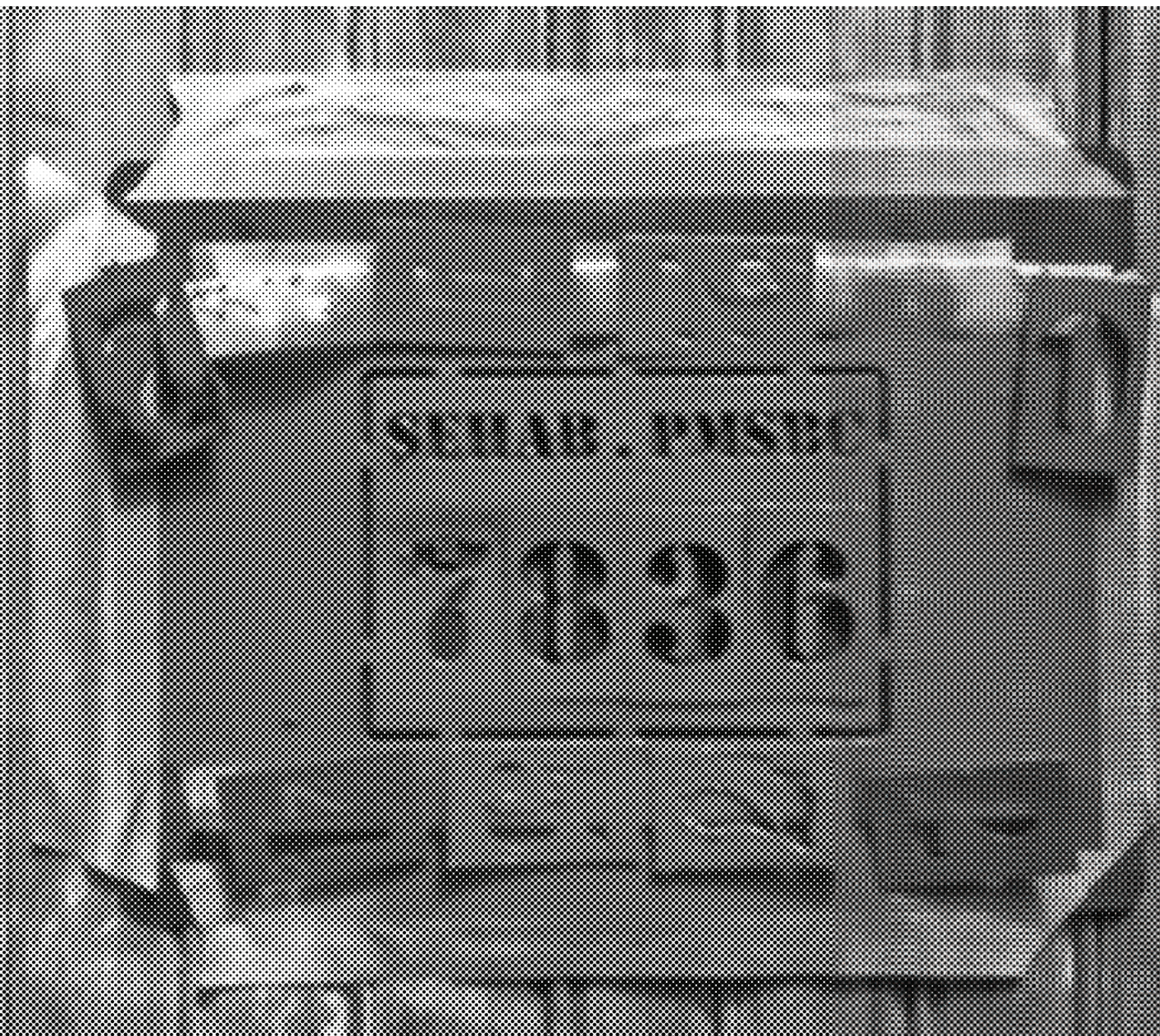

pessoas. Há que considerar principalmente que processos de urbanização de favelas têm-se demonstrado como processos longos e demorados, o que implica o "congelamento" não só dos aspetos físicos mas também de parte das vidas daquelas famílias.

Conscientes do caráter impositivo deste momento, e procurando minimizá-lo, a Peabiru criou um modelo de numeração estilizado, o qual foi implementado pelos técnicos da assessoria junto com os técnicos da Prefeitura de São Bernardo, no Batistini, no momento em que, para além da marcação do edifício, era realizado o cadastro físico e socioeconômico ${ }^{72}$, acompanhado pelo esclarecimento de dúvidas personalizado para cada família.
A 'mão leve', assim como as outras práticas dos arquitetos militantes, vai-se revelando nas posturas, atitudes, propostas e representações. Ela não tem a ver com a precarização do projeto, nem com um culto à pobreza: a captura de padrões e o reconhecimento da inteligência existente na autoconstrução se somam a uma ética no projetar, que está totalmente permeada pelo respeito ao espaço construído socialmente. Obviamente, não podemos ignorar que em todos os casos mencionados, trata-se de projetos com custo muito controlados, mas isso não redunda na precarização do projetar. Ainda que as obras construídas, em muitos casos, possam ter reduzido os padrões, acabamentos e soluções projetadas fig. 40 Sistema de selagem

e cadastramento, para

identificação das casas no

levantamento, desenvolvido pela Peabiru e aplicado no Batistini (SBC). Fonte: cedida por Peabiru TCA. 


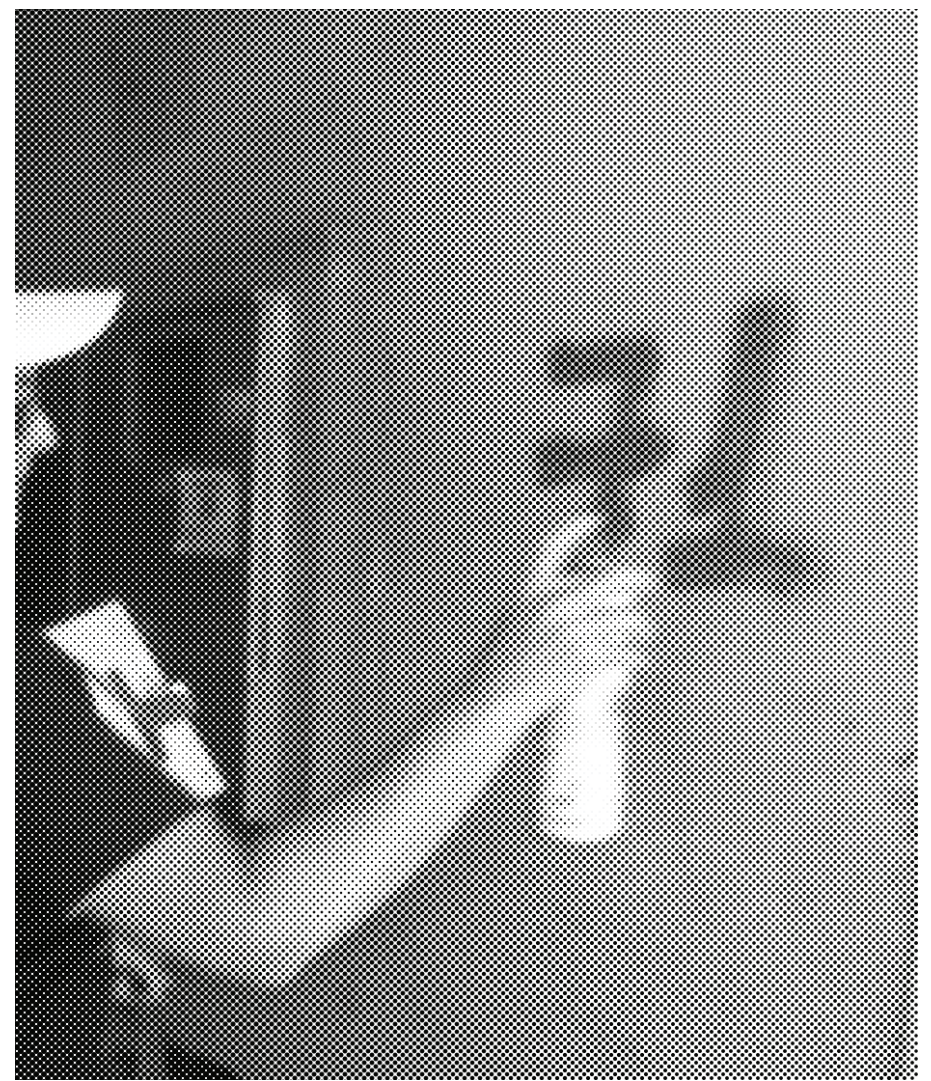

72. Para mais informações sobre este cadastro, ver Práticas: Globalidades \& Particularidades. pelos arquitetos militantes. O que apresentamos aqui trata-se do reconhecimento da constante revisão de atitudes, traçados e propostas no processo de urbanização de favelas, o que se acentua ainda mais no momento da concretização da obra como veremos na prática seguinte. Estamos nos referindo portanto a técnicas desenvolvidas pelos militantes em urbanização de favelas que correspondem a uma ética que reconhece a importância de uma estética respeitosa com as histórias da cidade autoconstruída.

\section{PRÁTICA: PROJETISTA DE CANTEIRO}

A Prática: projetista de canteiro já foi sendo enunciada em outras anteriormente descritas. A presença e a prática de decidir projeto e desenhar no canteiro ou fazer ambos simultaneamente com o andamento da obra eram, como já referimos, mais comuns fig. 41 Habitual sistema de selagem utilizado para intervenção em favelas, que a Peabiru critíca por seu caráter impositivo e pouco estético (SANTO AMORE e MARQUES, 2015, informação verbal em entrevista realizada em 17/11/2015, São Paulo). Fonte: cedida por Milton Nakamura

nas experiências dos anos 80, 90 e começo dos anos 2000 .

Como nos lembra Milton Nakamura, sobre as experiências de Diadema ( I 989-1 996), por vezes, nem existia projeto. Eram os técnicos em obra que tomavam as decisões, em diálogo direto entre moradores e trabalhadores da própria obra (NAKAMURA, 20 I 5 , informação verbal ${ }^{73}$ ). Esta prática era limitada no sentido do reconhecimento da escala urbana e da intervenção como uma potencial transformação de grande alcance. No entanto, pela diminuição de processos, burocracias e tomadas de decisão, as intervenções levavam tempos muito reduzidos, o que de certa forma, era benéfico para a população moradora. Nas palavras de Nakamura (20 I 5, informação verbal $^{74}$ ) algumas favelas demoravam apenas I ano para finalizar o processo de urbanização. 
Nos processos contratados via administração direta, tal como na Serrinha ou Tamarutaca, os arquitetos lembram a facilidade das tomadas de decisão em campo mas também a possibilidade de discussão e acordos verbais, durante o processo de construção. Esta prática possibilitava a adequação às necessidades de cada um dos moradores impactados pela implementação da obra.

Sobre a Vila Popular, Wagner Germano lembra que o projeto era feito no escritório da Usina, mas com "idas e vindas” à comunidade, para verificação de dúvidas e adaptações de projeto, se necessário. Para o arquiteto, "é necessário conhecer a realidade para decidir sobre ela" (GERMANO, 2015 , informação verbal 75 ).

Também no Sílvio Sampaio, Heloisa Rezende e equipe dividiam o seu tempo entre estar no campo, conhecer a comunidade, acompanhar obra e adequar projeto. (REZENDE, 20 I 6, informação verbal ${ }^{76}$ )

Por se tratarem de processos que se aproximam da reforma (PETRAROLLI, 20 I 5), a urbanização de favelas pressupõe uma grande margem de imprevistos que podem surgir durante o processo de obra, e que portanto, implicam uma adaptação constante de projeto. Para essa adaptação seria importante a participação do projetista, conhecedor do território e sua população, assim como das diretrizes que o levaram a tomar tais decisões em detrimento de outras e capaz de as adaptar com o mínimo impacto sobre as restantes questões.
Os recentes modelos de contratação utilizados dificultam a permanência e interferência do projetista em obra. Ainda assim, os arquitetos com muita experiência em processos de urbanização de favelas reconhecem na prática de projetar no canteiro uma mais-valia para o desenrolar do processo de urbanização. Alexandre Marques, retomando a experiência do Capelinha (SBC), na qual, só passados 2 anos sobre a aprovação de projeto, a obra foi licitada e ganha por determinada construtora. Compreendendo a transformação nesse período de alguns aspectos da favela, mas também as limitações técnicas da empresa de construção para seguir rigorosamente a proposta realizada pela Peabiru e aprovada pela Prefeitura, a assessoria foi contratada pela própria construtora para a revisão de adequação do projeto executivo à realidade local, mas também às possibilidades técnicas de obra. Reconhecendo os tempos do processo de urbanização de favelas dentro das regras de contração que habitualmente e recentemente se tem aplicado, Alexandre sugere que talvez não devesse ser dado um peso tão grande para a definição de aspectos detalhados no projeto que segue para licitação. Tal poderia ser detalhado no momento de obra, junto com a construtora e conhecendo os recursos técnicos da mesma assim como o terreno e suas características, no momento da implantação da obra, o que poderia diminui as imprecisões de projeto face às obras, e a constante necessidade da sua revisão.

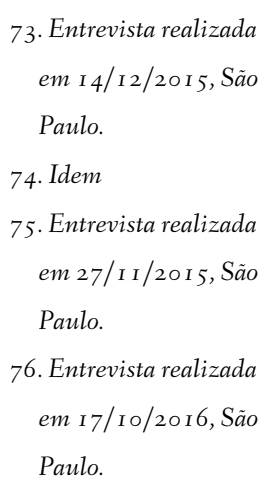

73. Entrevista realizada

Paulo.

em 27/II/20I5, São

Paulo. 


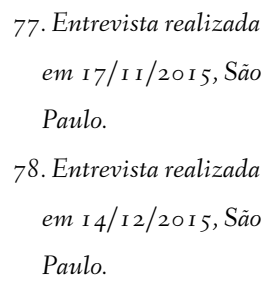

- projeto todo, ele tem uma virtualidade, porque a gente não sabe se ele vai ser aplicado, quando começarem as obras. E a gente não tem nenhuma garantia que vai participar. (SANTO AMORE e MARQUES, 2015, informação verbal[77)

Dentro da lógica atual de contratação de urbanização de favelas, Milton $\mathrm{Na}$ kamura lembra também que a definição da presença do projetista em obra pode e deve ser considerado pelos organismos promotores, no momento do pedido por recursos financeiros. Milton reconhece a importância da presença e participação em campo dos projetistas no momento da obra. Para o arquiteto e gestor público, revendo a sua vasta carreira e experiência e fazendo um paralelo com o histórico de urbanização de favelas, "precisamos olhar para trás para aprender com o que foi feito" (NAKAMURA, 20 I 5 informação verbal $\left.7^{8}\right)$, compreender a importância e benefícios das experiências passadas, mas também assumir os erros realizados, procurando evitá-los e adequá-los na forma de intervenção.

\section{PRÁTICA: O MEDIADOR [DE DISCIPLINAS, AGENTES, ATORES, ...]}

$\mathrm{O}$ arquiteto está muitas vezes colocado no papel de mediador entre as diferentes disciplinas que participam de um mesmo projeto. As diretrizes arquitetônicas são habitualmente as orientadoras do projeto estrutural ou de instalações, e ao arquiteto cabe o papel de verificar a adequação dos restantes projetos e/ou procurar uma conciliação da solução entre os projetistas.

$\mathrm{Na}$ urbanização de favelas o projeto nas e entre as diferentes disciplinas acontece quase de forma simultânea. A avaliação do risco e da melhor solução de contenção geotécnica, pode definir o desenho urbano, assim como impactar na remoções previstas. O desenho geométrico das ruas e instalação de infraestruturas vai ser condicionante do espaço urbano gerado. As relações de mobilidade intra e extra favela, podem ser balizadas pelos organismos de aprovação, assim como as questões ambientais, como o tipo de micro e macro drenagem a ser usada, seu desenho e materiais empregues. $\mathrm{O}(\mathrm{s})$ projeto(s) de urbanização de favelas acontecem na interpenetração das disciplinas e nesse processo o arquiteto aparece como mediador e conciliador entre elas. Esta reflexão é fruto da experiência da autora como projetista em urbanização de favelas e da discussões e encontros realizados no GE_Favelas ${ }^{79}$.

Esta pode também ser considerada uma das lacunas do ensino na arquitetura e urbanismo. Compreender e reconhecer a existência de outras disciplinas que podem definir o desenho do arquiteto, assim como a sua importância, sobretudo num projeto de escala urbana e impacto físico e social como este. 
Os militantes reconhecem este papel de mediador entre as disciplinas, e a importância da contribuição dos restantes técnicos para o resultado final. A crescente conscientização sobre a importância de questões ambientais, levou Milton Nakamura a adotar consultorias específicas para questões geológicas, de biologia e manejo de águas, no processo de definição de diretrizes para o Chafik-Macuco (Mauá, 20 I 3-20 I 5), pelo qual era responsável como gestor. Esta era uma preocupação pouco presente no início da sua atuação profissional, mas que hoje ele reconhece ter relação profunda sobre a manutenção, consolidação e prevenção de riscos e questões de salubridade ambiental urbana. Com base naquelas consultorias, e facilitando o contato entre as mesma e a empresa projetista contratada para desenvolvimento dos projetos de arquitetura e urbanismo - TEREZA Arquitetura - a equipe gestora tentou promover um diálogo entre todos os participantes, procurando viabilizar as propostas adequadas às necessidades locais. (NAKAMURA, 20 I 5 , informação verbal ${ }^{8 \circ}$ )

Para além das questões físicas, Milton afirma que um processo de urbanização de favelas tem que, obrigatoriamente, ser acompanhado por uma equipe social. Para ele, os técnicos sociais têm leituras que fogem do olhar do arquiteto, e que para este processo acontecer, os técnicos (físicos e sociais) têm que trabalhar em equipe constantemente.
Não abro mão disso: o arquiteto tem
que trabalhar junto com o pessoal do
social. $\bigcirc$ pessoal do social levantam
problemas que o arquiteto tem que
resolver, coisas que o projetista
não enxerga. (NAKAMURA, 2015
informação verbal ${ }^{81}$ )

Se o papel do arquiteto como mediador no que diz respeito às disciplinas de projeto é mais ou menos evidente, na urbanização de favelas esse papel pode também ser estendido à moderação entre diferentes agentes participantes do processo. É comum encontrarmos os militantes assumindo essa posição.

As assessorias técnicas assumem essa vertente como a base da sua criação, num triângulo de atuação onde em cada vértice se encontravam organizados os movimentos sociais, o poder público, e a assessoria técnica. Este seria o tripé onde assentariam as forças, possibilidades e agentes de atuação, que através do diálogo e ação conjunta, possibilitariam o alcance de resultados pelo menos em sua origem. Hoje, com a complexificação dos programas de financiamento públicos e da entrada de novos agentes no campo da produção de Habitação de Interesse Social, esta relação tripartida ramificouse. Aos técnicos assessores, dentro ou fora de assessorias formais, ainda é reconhecido o conhecimento e aconselhamento técnico. Mas a partir de Programas tais

\footnotetext{
79. Tanto o percurso

profissional da autora

quanto a apresentação

do GE_Favelas (Grupo

de Estudos sobre Ur-

banização de Favelas,

foram abordados na

Apresentação do

presente trabalho.

8o. Entrevista realizada

em I 4/I2/2OI 5, São

Paulo.

8I. Idem

82. Participei das Oficinas

ATHIS realizadas

em Campinas e São

Paulo, onde foram

introduzidas questões

teóricas, mas também

exercícios práticos

sobre a atuação da

assistência / assessoria

técnica em arquitetura

e urbanismo. Para mais

informação ver: www.

athis.org.br
}

(próxima página) fig. $42 \mathrm{e}$

43. Oficinas Athis-São Paulo,

organizadas pela Peabiru em

2016. Imagens de visita de

campo e trabalhos de grupo.

Fonte: cedida por Peabiru

TCA 


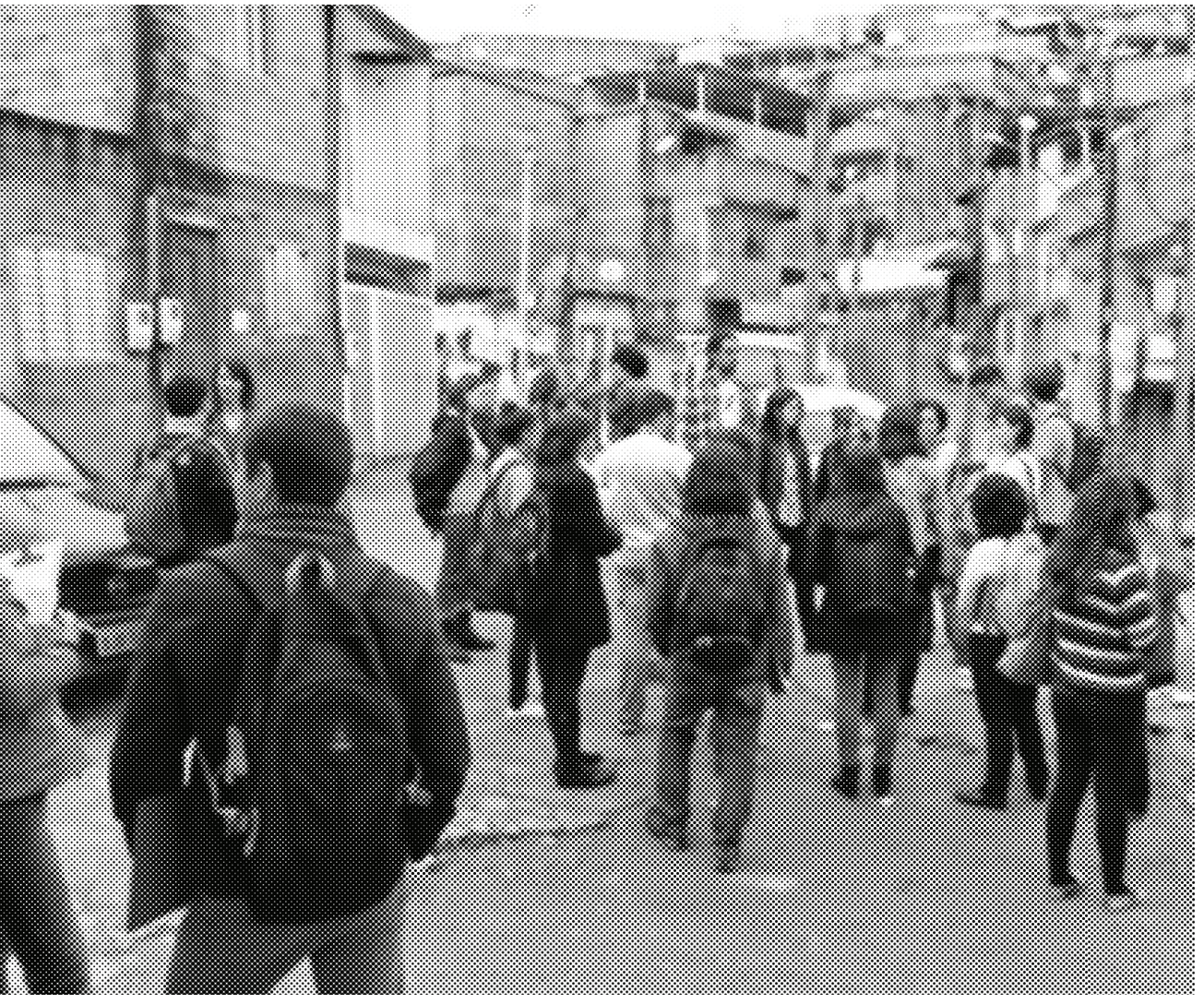

como o PMCMV, resta-lhes um papel de assistência, num jogo que vem sendo definido apenas no plano político, econômico e burocrático. Essa foi uma das reflexões apresentadas pela Peabiru nas Oficinas ATHIS - Oficinas sobre Assistência Técnica para Habitação de Interesse Social, realizadas em algumas cidades do Estado de São Paulo entre 2015 e $2016^{82}$.

Envolvidos ou preocupados com as questões sociais, com as decisões políticas e com o impacto das intervenções físicas, encontramos os sujeitos militantes na moderação de diálogo entre poder público, moradores da favela e/ou suas associações representativas. Temos visto outros agentes aparecerem com participação relevante na urbanização de favelas, como as gerenciadoras ${ }^{83}$, as empresas construtoras e órgãos de aprovação que muitas vezes são distintos do órgão público promotor do processo. Todos estes agentes são complexos e pouco uniformes. Dentro do mesmo agente, podem haver divergências de interesses e opiniões, como é o caso dos moradores, que dependendo do assunto podem não concordar com a solução proposta, ou o próprio poder público respondendo a demandas de diferentes secretarias, ou na mudança de gestões partidárias. Estes são apenas alguns dos exemplos da complexidade de estar dentro de um diálogo entre os variados agentes participantes num processo de urbanização de favelas.

O sujeito militante, preocupado com uma resposta adequada às reais necessidades da população moradora, procura através de diálogo e projeto, a aglutinação das informações e interesses dos agentes, procurando a viabilização de uma proposta que se aproxime do ideal colocado. Para isso serve-se também da PrÁtica DA COMUNICAÇÃO ACESSÍvEL, já abordada, disponibilizando-se para o diálogo, e reconhecendo a diversidade de posturas e discursos. 
Dentro das definições das habituais regras de contratação, os sujeitos militantes admitem que a viabilização da concretização da urbanização de favelas, implica a relação e diálogos aproximados entre projetista e construtora. Já falamos da experiência da Peabiru no Capelinha, também Jonathas Silva reconhece a importância desse diálogo, para além dos restantes, que estes sujeitos já procuram manter com a população moradora e com o poder público nos seus diferentes agentes. "Tem toda uma parte de infraestrutura que depende de um diálogo e de você ter parceiros." (SILVA, 2015 , informação verbal ${ }^{84}$ )

Por vezes vemos estes sujeitos extrapolarem as relações básicas entre os agentes "obrigatórios" no processo. Manoel Ribeiro, procurando uma intervenção com uma escala para além da física, pretendia estabelecer para a Serrinha uma aproximação e participação ativa na e com a cidade do Rio de Janeiro, não apenas em um sentido (os moradores já eram participantes ativos na cidade como um todo), mas bidirecional canalizando o interesse da população geral para visitar e participar das atividades na comunidade. Para tal, além da proposta física que estimulava as manifestações culturais já existentes, Manoel recorreu aos seus contatos em meios de comunicação para divulgar as pré-existências da Serrinha, como o Jongo entre outras atividades culturais e religiosas. (RIBEIRO, $20 \mathrm{I} 5$, informação verbal ${ }^{85}$ )

\section{PRÁIICA: GLOBALLDADES \& PARTICULARIDADES}

Como introduzimos inicialmente, um dos critérios desta escolha de sujeitos foi a vasta experiência em processos de urbanização de favelas. Na reflexão, através da entrevista a cada um deles, sobre a atuação profissional e experiência na intervenção em favelas, aparece-nos comum a noção sobre a ampliação da escala de intervenção destes processos ao longo da história na forma de atuar em urbanização de favelas.

Há um reconhecimento da importância de processos desta natureza tomarem a escala de plano de intervenção urbana ampliada. Os militantes sabem que a intervenção em favelas, para se concretizar efetivamente na cidade, tornando-a parte da mesma, precisa de compreender a possibilidade de intervenção em questões que ultrapassam os limites físicos designados de uma favela.

Se essa é uma visão mais disseminada nos dias de hoje, ela foi gradativamente ganhando essa escala e importância. Milton Nakamura lembra como as primeiras intervenções dos anos 80 e 90 em Diadema pretendiam apenas as resoluções locais dos problemas de acesso às redes e segurança de permanência dos moradores em situação precária e irregular. E como isso levou a decisões e execuções que se traduzem nos dias de hoje em situações complexas urbanas, como a sobre-densidade do território

\footnotetext{
83. Nesta pesquisa não

avançamos na ex-

ploração e explanação

do papel das geren-

ciadoras nos processos

de urbanização de fave-

las, por não aparecerem

com grande representa-

tividade nas entrevistas

realizadas. No entanto

reconhecemos o seu

papel e a importância

que este agente tem

adquirido no cenário

atual nos processos de

urbanização de favelas.

Sobre o papel de Geren-

ciadoras em Urban-

ização de Favelas, ver

PULHEZ (20 I 4).

84. Entrevista realizada em 26/10/2015, São

Paulo.

85. Entrevista realizada

em 20/II/2015, Rio de

Janeiro.
} 
86. Entrevista realizada em I 4/I 2/20 I 5, São Paulo.

87. Entrevistas realizadas, respectivamente em 26/10/20 I 5, São Paulo e 23/ I I/2016, Rio de Janeiro. e a existência de problemas ambientais de difícil resolução, como o manejo das águas urbanas, entre outros. (NAKAMURA, 2015 , informação verbal ${ }^{86}$ )

Comparando Cantagalo e Pavão-Pavãozinho com a Rocinha, Jonathas Silva afirma que a principal mudança de um processo para o outro foi a ampliação da escala. Para a Cantagalo e Pavão-Pavãozinho (RJ, 1999-2003) a indicação era para a intervenção fosse de pequena escala, para pequenos espaços urbanos (os possíveis dentro da favela), e também da infraestrutura, mas apenas dentro dos limites físicos da favela. Na verdade, Cantagalo tratou-se de um processo e contrato diferente do de Pavão-Pavãozinho, apesar das favelas serem contíguas e apresentarem problemas e soluções comuns. Mas no processo, coordenado pelos arquitetos, foram apresentados produtos distintos, por definição de contrato e exigência do órgão promotor. Verificamos essa duplicidade nos documentos gráficos também nos documentos que tivemos acesso. Mas na análise e depoimentos dos arquitetos, encontramos testemunhos de um trabalho desenvolvido em conjunto, pensando nas soluções integrais para toda a região de forma ampla (SILVA, $2015 \mathrm{e}$ TÂNGARI, $20 \mathrm{I} 6$, informação verbal ${ }^{87}$ ). Apesar desta forma de trabalho desenvolvida pelos projetista, no Favela-Bairro as intervenções tinham alcance restringido à favela em si, sem procurar um diálogo com a restante cidade. Já na Rocinha (2007-
2008), a proposta do Concurso motivador do contrato e processo, implicava um alcance de grande escala, tratava-se de um Plano Sócio-Espacial para o Bairro. Outros fatores contribuíram para esse aumento de escala. A própria dimensão da Rocinha (maior física e demograficamente) relativamente a Cantagalo e Pavão-Pavãozinho acaba por tomar uma proporção de intervenção urbana, à escala de uma cidade. Também o processo de contratação que aconteceu, possibilitando que fossem os próprios projetistas a definir o seu escopo, e incluir as propostas que achavam necessárias para a intervenção naquele território, permitiu a definição de grandes escalas de intervenção, e de planejamento futuro para o bairro. Toledo encarou esta como uma proposta de realização de um Plano Diretor para a Rocinha.

No seu entendimento, a proposta para o Concurso já devia prever a sua viabilização e portanto a aproximação à comunidade. Na sua atitude da época queria: "preparar esse concurso, como se tivesse fazendo plano diretor (...) fazer um making of, antes do making. (...) Aí fiz uma reunião com moradores de uma área da Rocinha, mostrando já uma proposta, para validar a proposta e se os moradores não gostarem, a gente não entra no concurso." Mas aproveitou também para explicar o risco de poder não ganhar, e mesmo ganhando de poder não ser construído. (TOLEDO, 2015 , informação verbal ${ }^{88}$ ) 
No final, a ideia inicial do Plano encontrou algumas contrariedades pelo caminho. Mas o processo foi desenvolvido pelos projetistas ambicionando essa ampla escala de intervenção e o impacto sócio espacial de potencial urbano na e para a cidade do Rio de Janeiro.

Não só nesta comparação, mas também com o programa $\mathrm{PAC}$ e as recentes propostas de intervenção em favelas, como o Renova SP ou o Morar Carioca, demonstram a ampliação da escala e a ambição para uma intervenção que tem o potencial de alterar não só uma favela, mas contribuir para a cidade como um todo, ou pelo menos para o bairro em que determinada favela se encontra.

No entanto, se nas propostas e discursos, a necessidade de intervenção de grande escala para a transformação do paradigma: favela, parece evidente, essa ambição tem tido cada vez mais dificuldade em se efetivar. Escalas mais amplas significam intervenções mais complexas, e processos mais demorados, o que se tem demonstrado na pouca eficácia, no sentido da sua real e completa concretização, de processos de urbanização de favelas (PETRAROLLI, $2015)^{89}$.

Mas mesmo reconhecendo e exercendo práticas que procuram alcançar a dimensão urbana para lá dos limites da favela, os militantes não esquecem as particularidades de cada casa, cada família, de cada lugar. $\mathrm{Na}$ verdade, em sua prática, os militantes re- correm às particularidades para embasar os projetos globais, procurando o equilíbrio na diversidade. Os levantamentos casa-a-casa são representantes desse mesmo interesse. Usados na maioria das vezes para definição de estratégias de remoção, reassentamento, consolidação e melhorias habitacionais, são levantamentos que procuram reconhecer as características espaciais, mas também socioeconômicas da favela e suas famílias, e demonstrar que as diretrizes aparentemente mais evidentes, podem não ser as mais adequadas para determinada situação, como no caso já relatado na Vila Popular, quando a Usina adequou projeto à situação social dos moradores da favela.

Um exemplo da prática destes militantes que equilibra a importância das Globalidades com as Particularidades da favela é o IPHAB - Índice de Precariedade Habitacional, metodologia que tem vindo a ser explorada pela Peabiru em seus processos de urbanização de favelas. Trata-se de uma pesquisa de metodologia da própria assessoria, motivada pela dificuldade e pelo reconhecimento da importância de definição de quem fica ou quem sai numa urbanização de favela (SANTO AMORE et al., 20 I 4 C).

Recorrendo ao LEPAC (Levantamento Planialtimétrico Cadastral) e cruzando com outras informações recolhidas em questionário próprio, são produzidos mapas síntese que resultam na leitura global da favela a partir das suas particularidades. O questio-
88. Entrevista realizada em 23/I I/20I5, São Paulo.

89. Podemos encontrar outras justificativas para a pouca realização de Urbanização de

Favelas, sobretudo de processos recentes, e que Petrarolli (2015), entre outros pesquisadores, aborda em sua pesquisa Mas com certeza a com plexificação dos processos e dos contextos têm contribuido para atrasos e baixa eficiência. 
fig. 44 Tabela de indicadores

de precariedade utilizados

pela Peabiru para identi-

ficação do IPHAB. Fonte:

cedida por Peabiru TCA nário tem sido desenvolvido e é realizado no local pelos técnicos da Peabiru, com visitas a todas as moradias do assentamento, e levantamento de informações que cruzam dados socioeconômicos das famílias, as condições físicas, de habitabilidade e acesso à infraestrutura da moradia, e os dados ambientais e de risco da área. O resultado é a sinalização de diferentes graus de precariedade aplicados a cada edificação, representados em cores sobre o mapeamento. Esta sistematização possibilita o embasamento para diretrizes de projeto, mas também um catálogo de informações de fácil acesso onde é possível tirar dúvidas no momento de definição de algumas decisões projetuais mais específicas (SANTO AMORE et al., 20 I 4c). A utilização do IPHAB, ou registros semelhantes, como instrumento de registro e pesquisa, pode ainda possibilitar uma reflexão sobre a transformação e avaliação ao longo do tempo de intervenções em favelas, ou pelo menos - o que já não é pouco - uma pesquisa sobre a transformação na morfologia destes territórios.

Alexandre Marques e Caio Santo Amore vão ainda mais longe sobre a potencialidade do uso desta ferramenta, lembrando a sua utilização no momento da justificativa da necessidade de projetos para melhorias habitacionais, complementação que a Peabiru defende como fundamental na urbanização de favelas. (SANTO AMORE e MARQUES, 20 I 5 , informação verbal ${ }^{\circ}$ )

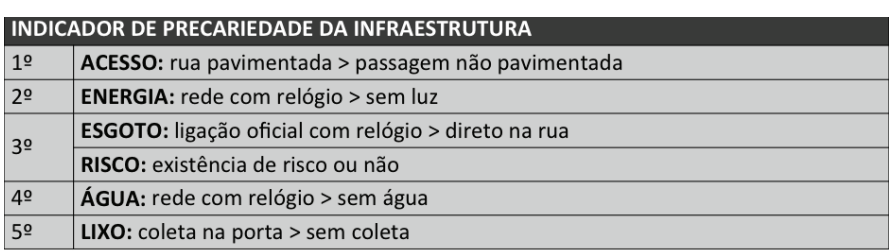

\begin{tabular}{l|l|}
\hline \multirow{2}{*}{ INDICADOR DE PRECARIEDADE DO IMÓVEL } \\
\hline 10 & MATERIAL: concreto/alvenaria > madeira \\
\hline \multirow{2}{*}{0} & REVESTIMENTO EXTERNO: em todas fachadas > sem revestimento \\
\cline { 2 - 3 } & COBERTURA: laje com telha > improvisada \\
\hline 30 & ESTRUTURA: sem trincas > grandes trincas \\
\hline 40 & ILUMINAÇÃO E VENTILAÇÃo RUIM: quantos e quais cômodos \\
\hline \multirow{4}{*}{50} & REVESTIMENTO INTERNO: em todos cômodos > sem revestimento \\
\cline { 2 - 3 } & RESERVATÓRIO DE ÁGUA: com tampa > sem reservatório \\
\cline { 2 - 3 } & INSTALAÇÕES ELÉTRICAS: com QDL e conduítes > sem QDL e fiação exposta \\
\hline \multirow{2}{*}{60} & PISO INTERNO: em todos os cômodos > piso improvisado \\
\cline { 2 - 3 } & MOFO E UMIDADE: ineXistente > existente nas áreas molhadas e secas \\
\hline \multirow{3}{*}{ INDICADOR DE PRECARIEDADE DA OCUPAÇÃO } \\
\hline \multirow{2}{*}{10} & RELAÇÃO PESSOA/QUARTO \\
\hline 20 & RELAÇÃO PESSOA/BANHEIRO \\
\hline \multirow{2}{*}{30} & RELAÇÃO PESSOA/SALA \\
\cline { 2 - 3 } & RELAÇÃO PESSOA/COZINHA \\
\hline
\end{tabular}




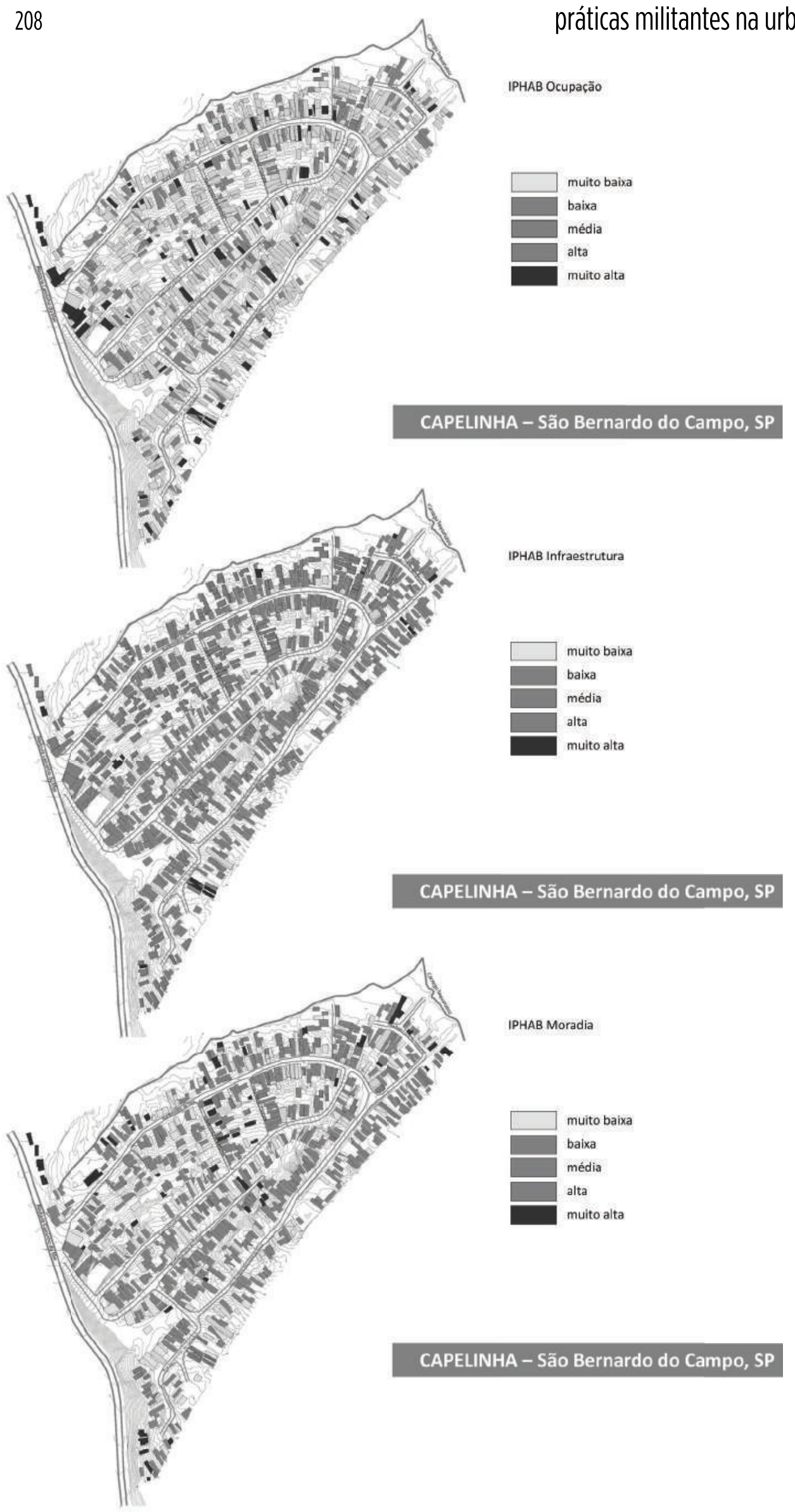

fig. 45, 46 e 47 Mapas

resumo do IPHAB para o

Capelinha (SBC). Fonte:

cedidas por Peabiru TCA

(página seguinte) fig. 48,49

e 50 Mapas e tabelas resumo

do IPHAB para o Batistin

(SBC). Fonte: cedidas por

Peabiru TCA 
práticas militantes na urbanização de favelas

IPHAB Ocupação

\begin{tabular}{|c|c|c|c|}
\hline pontuação & classificação & \multicolumn{2}{|c|}{ quantidade de imóveis } \\
\hline $0-14,9$ & muito baixa & 1.094 & $55,11 \%$ \\
\hline $15-29,9$ & baixa & 417 & $21,01 \%$ \\
\hline $30-44,9$ & média & 96 & $4,84 \%$ \\
\hline $45-59,9$ & alta & 46 & $2,32 \%$ \\
\hline $60-100$ & muito alta & 11 & $0,55 \%$ \\
\hline & sem informação & 321 & $16,17 \%$ \\
\hline
\end{tabular}

IPHAB Infraestrutura

\begin{tabular}{|c|c|c|c|}
\hline pontuação & classificação & \multicolumn{2}{|c|}{ quantidade de imóveis } \\
\hline $0-14,9$ & muito baixa & 187 & $9,42 \%$ \\
\hline $15-29,9$ & baixa & 226 & $11,39 \%$ \\
\hline $30-44,9$ & média & 203 & $10,23 \%$ \\
\hline $45-64,9$ & alta & 283 & $14,26 \%$ \\
\hline $65-100$ & muito alta & 874 & $44,03 \%$ \\
\hline & sem informação & 212 & $10,68 \%$ \\
\hline
\end{tabular}

IPHAB Moradia

\begin{tabular}{|c|c|c|c|}
\hline pontuação & classificação & \multicolumn{2}{|c|}{ quantidade de imóveis } \\
\hline $0-14,9$ & muito baxa & 548 & $27,61 \%$ \\
\hline $15-34,9$ & baixa & 768 & $38,69 \%$ \\
\hline $35-51,9$ & média & 251 & $12,64 \%$ \\
\hline $52-69,9$ & alta & 83 & $4,18 \%$ \\
\hline $70-100$ & muito alta & 123 & $6,20 \%$ \\
\hline & Sem informação & 212 & $10,68 \%$ \\
\hline
\end{tabular}
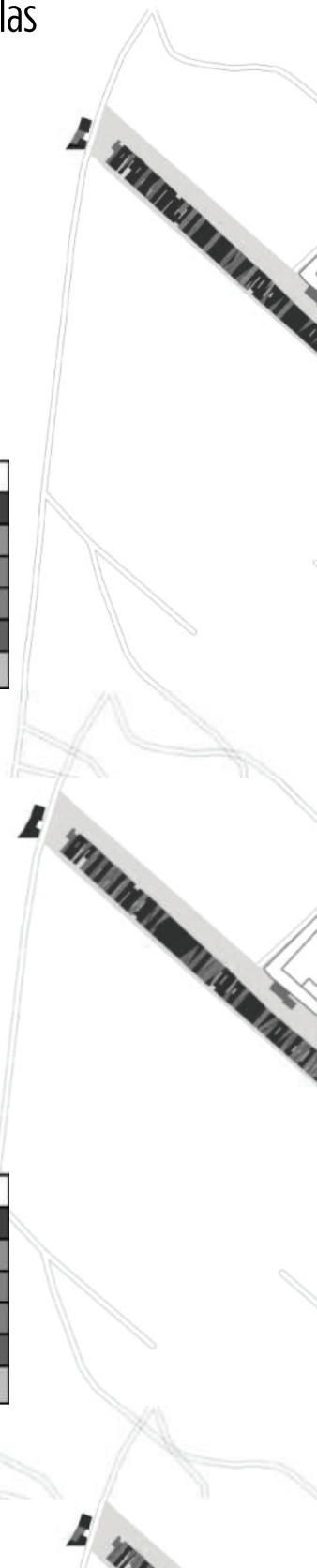


\begin{tabular}{|l|c|c|}
\hline Problemas & \multicolumn{2}{|c|}{$\begin{array}{l}\text { Proporção do problema em relação } \\
\text { ao total de problemas na área }\end{array}$} \\
\hline Infiltrações/umidade & $43,53 \%$ & $\begin{array}{l}\text { principalmente pela } \\
\text { parede, seguida de } \\
\text { infiltração por laje }\end{array}$ \\
\hline $\begin{array}{l}\text { Estrutura da } \\
\text { edificação }\end{array}$ & $27 \%$ & $\begin{array}{l}\text { Principalmente } \\
\text { subdimensionamento } \\
\text { e rachaduras, com } \\
\text { ocorrência de } \\
\text { recalque }\end{array}$ \\
\hline $\begin{array}{l}\text { Iluminação e } \\
\text { ventilação }\end{array}$ & $11,76 \%$ & $\begin{array}{l}\text { No acesso à } \\
\text { residência }\end{array}$ \\
\hline $\begin{array}{l}\text { Acesso à edificação } \\
\text { Instalações } \\
\text { hidráulicas }\end{array}$ & $9,41 \%$ & \\
\hline Instalações elétricas & $3,3 \%$ & \\
\hline $\begin{array}{l}\text { Inadequação às } \\
\text { necessidades das } \\
\text { familias }\end{array}$ & $3,5 \%$ & Por adensamento \\
\hline Remoções parciais & $1,2 \%$ & \\
\hline
\end{tabular}

tereza

arquitetura

uroaniemo

\author{
fig. 51 Tabela de diagnósti- \\ co de problemas habita- \\ cionais a serem resolvidos \\ por projeto de melhorias, \\ realizado por TEREZA \\ Arquitetura.. Fonte: cedida \\ por Milton Nakamura
}

A defesa e reivindicação por melhorias habitacionais protagonizada por alguns destes sujeitos, e outros que compreendem a sua importância num processo de urbanização de favelas, também demonstra a complementaridade entre as diferentes escalas de atuação. Sujeitos como Milton Nakamura ou a assessoria Peabiru têm procurado introduzir esta dimensão nos processos dos quais participam. Para os sujeitos militantes, a intervenção nas urgências sobre o território, como a complementação ou implantação de infraestrutura é tão importante quanto a condição em que ficam os moradores após as intervenções físicas de um processo de urbanização de favelas. Para isso, não basta a intervenção nos espaços e redes públicos e coletivos e o reassentamento adequado das famílias que precisam ser removidas. É necessário introduzir práticas que reconheçam a qualidade (ou precariedade) e particularidade de cada um dos edifícios que permanecem, assim como possibilidades de intervenção, nestes, que habitualmente são a maioria do tecido físico, evitando a consolidação de precariedades, e a resolução de todas as inadequações habitacionais. (SANTO AMORE e MARQUES, 20 I 5 , informação verbal ${ }^{91}$ )

No Chafik-Macuco, se por um lado
Milton Nakamura se preocupou com uma pesquisa abrangente sobre o território para determinar as diretrizes de intervenção, englobando inclusive questões ambientais, como promotor do processo, orientou a introdução das propostas para as melhorias habitacionais. Esta ação foi realizada por equipe específica, dentro do escritório TEREZA Arquitetura, e através de uma metodologia que identificou tanto patologias de precariedade habitacional, como as intervenções necessárias para a sua solução. Nakamura reconhece a importância da definição desta proposta ainda em fase de projeto básico, para a sua introdução junto com o pacote de pedido de financiamento e sua viabilização na etapa de obra. (NAKAMURA, 20 I 5 , informação verbal ${ }^{92}$ )

Nos processos de urbanização de favelas que têm desenvolvido, a Peabiru tem proposto não só a identificação, através do IPHAB das tipologias de precariedades que podem ser resolvidas através das melhorias habitacionais, como a sua solução através de kits de intervenção. No entanto, na maioria dos processos, esta ainda é a intervenção que dificilmente é alcançada, por especificidades técnicas e logísticas, e normalmente, por escassez de recursos financeiros. (SANTO AMORE e MARQUES, 20 I 5 , informação verbal93)

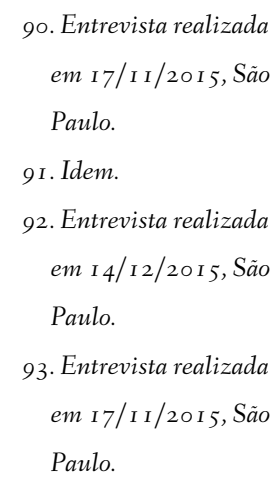




\section{AS REFLEXÕES SOBRE A(S) PRÁTICA(S)}

\footnotetext{
94. Entrevista realizada em I 4/I 2/20 I5, São Paulo.
}

Para além da indicação e definição das práticas militantes acima descritas, nas entrevistas, surgiram reflexões sobre estas mesmas práticas, algumas induzidas por questões mais diretas, outras como reflexo de uma revisão sobre as experiências relatadas, revelando a transformação vivenciada por estes sujeitos fruto dos próprios percursos profissionais.

Ao questionamento sobre as decisões e motivações que os levaram aos processos de urbanização de favelas e às práticas que deliberadamente executaram, no sentido do que aqui colocamos como militância, revelam-se algumas intenções políticas e de justiça social. Ao mesmo tempo, aparecem as contradições dos processos e das práticas destes sujeitos, ou às quais são submetidas face ao posicionamento técnico-social e político, que assumem.

\section{REFLEXÃO: INOVAÇÃO \& CONSERVADORISMO}

Em auto-avaliação sobre suas práticas há um reconhecimento de algum protagonismo nas metodologias desenvolvidas e praticadas na urbanização de favelas feita por sujeitos militantes. A necessidade de inventar formas de atuar frente a um campo pouco conhecido e explorado da arquitetura e urbanismo, indicam um certo pioneirismo e inovação reconhecido na intervenção em favelas.
Milton Nakamura lembra os avanços realizados pelos técnicos em Diadema nos anos 80 e 90 , mas ao mesmo tempo, reconhece como alguns dos parâmetros definidos nessas intervenções, foram difundidos e reproduzidos sem grande questionamento. Milton lembra especificamente, da definição das dimensões dos lotes para as áreas irregulares, assim como as dimensões de rua. Foram padrões de intervenção mínimos, adaptados às necessidades de sobre-densidade e limitações técnicas e financeiras de Diadema na época, que acabaram por se perpetuar como referência para a urbanização de favelas em outros municípios. (NAKAMURA, 20 I 5, informação verbal94)

No que diz respeito à inovação, tal como aqui colocamos, encontramos estes sujeitos fazendo propostas ousadas, diferentes ou em sentido totalmente oposto ao que habitualmente encontramos na atuação do poder público e dos próprios arquitetos e urbanistas na mesma época. A inovação pode ser associada a uma metodologia de análise, como por exemplo o IPHAB desenvolvido pela Peabiru, uma tipologia habitacional, ou várias, dentro de um mesmo conjunto habitacional ou favela, lembremos por exemplo a casa evolutiva da Peabiru, ou unidades de encosta desenvolvidas para o Chafik. Tratam-se de soluções que questionam e propõem transformações aos modos habituais de fazer, introduzindo avanços técnicos ou metodológicos que contribuem 
para a reflexão e prática de urbanização de favelas, e se estendem ao campo da arquitetura e urbanismo.

Apesar da sua contribuição e possibilidade de avanço das disciplinas, é comum que esta ousadia propositiva se depare com barreiras no conservadorismo, protagonizados por outros atores participantes do processo.

Exemplo disso foi a proposta da Quadra Arquitetos para Brás-de-Pina (RJ, I 968 I 97 I) com algum sentido mais socializante do espaço, da distribuição dos lotes e do desenho habitacional, e prevendo as potencialidades de densificação da região. Esta proposta foi negada pela população moradora que preferia uma solução mais semelhante ao que se fazia no resto da cidade.

Durante as obras houve uma série de procedimentos bem elucidativos. Quando se tratou da divisão de terra, por exemplo, apresentamos aos moradores cinco alternativas que ficaram em exposição na sede da Associação para debate geral. Havíamos insistido muito junto à CODESCO por uma solução em condomínio horizontal que considerávamos ser a melhor saída para absorver as previsíveis mudanças em um lugar onde a densidade já era tão alta. Se, no futuro, houvesse necessidade de verticalização, não seria preciso enfrentar as dificuldades de remembrar uma

\begin{abstract}
terra excessivamente parcelada.
Algum tempo depois, recebíamos

um relatório da Associação, optando pela proposta mais "reacionária" em que cada terreninho de $120 \mathrm{~m} 2$ seria de propriedade particular da família que o ocupasse. As justificativas que acompanhavam 0 relatório eram muito claras: todos entendiam as razões que recomendavam a inovação, só que não queriam ter padrões diferentes dos considerados normais para o resto dos moradores da cidade. (SANTOS, 1981, pg 64)
\end{abstract}

Ainda sobre a necessidade de exploração de um "novo" campo de trabalho, Heloisa Rezende lembra que para o projeto de Silvio Sampaio, ela e demais equipe, tiveram que aprender fazendo, pois, tratando-se de uma equipe jovem, não traziam nenhuma experiência, nem profissional nem das respetivas formações técnicas (REZENDE, 20 I 5, informação verbal95). Lembremos que este processo data dos anos 2000 , período no qual podemos considerar já existir algum conhecimento acumulado sobre urbanizações de favelas. A constatação de Heloisa reflete aquilo que outros destes sujeitos nos vão demonstrando pelos seus depoimentos. "Não existe metodologia sobre urbanização de favelas." (SILVA, 20 I 5, informação verbal ${ }^{96}$ ) "É uma prática que se aprende fazendo." (SANTO AMORE e MARQUES, 20 I 5, informação

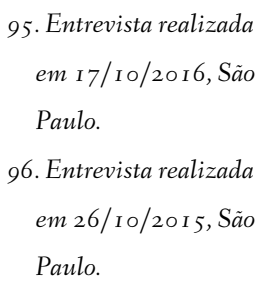




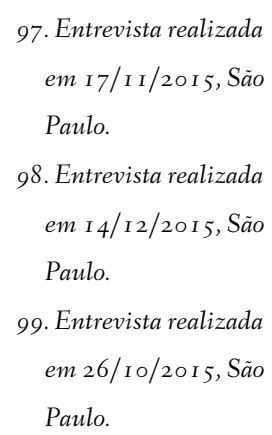

7. Entrevista realizada em I 7/I I/20I5, São

verbal97). De alguma forma, isso revela o conhecimento truncado sobre a temática e a dificuldade de acesso às experiências, práticas e casos de estudo, no sentido de aprendizado, avaliação, ou acesso à informação sobre os processos, o que, em certa medida, pode dificultar o seu progresso.

\section{REFLEXÃO: REVISÃO CRÍTICA}

Apesar de reconhecerem alguns dos avanços que protagonizaram, estes sujeitos reconhecem também os seus erros de percurso e atuação. Nesse reconhecimento verificamos um embasamento para o aprendizado sempre constante. A auto-avaliação crítica admitindo os erros ou práticas menos adequadas aplicadas a determinada situação ou em determinado momento, reforça a designação destes como militantes. No reconhecimento e aprendizado pelo seu percurso encontramos a superação e melhoria das mesmas.

Milton Nakamura, por exemplo, compreende a limitação da escala de atuação das intervenções de Diadema (I 989-I 99I), e procura no Chafik-Macuco (Mauá, 20 I 320 I 5) uma ampliação que chega a alcançar disciplinas menos comuns em outros processos de urbanização de favelas, como a consultoria feita por biólogos e o mapeamento dos cursos de água para a definição das diretrizes de atuação. (NAKAMURA, 2015 , informação verbal ${ }^{9}$ )

Também Jonathas Silva, na comparação entre a sua própria postura como técnico em Cantagalo e Pavão-Pavãozinho (RJ, I 996-2003) e 5 anos mais tarde na Rocinha (RJ, 2007-2008), admite a transformação do seu entendimento sobre as intervenções em favelas, e sobre o projeto participante com as comunidades. No Favela-Bairro, Jonathas encara a intervenção como a proposta limitada ao desenho dos espaços vazios. $\mathrm{Na}$ Rocinha, a intervenção toma escala de plano diretor, com a especificação de desenho sobre uma área que deverá ser tomada como referencial para as outras áreas de intervenção. Sobre as metodologias participativas, Jonathas muda a sua opinião que passa de considerá-las como supérfluas, já que no seu entendimento seria o projetista o agente capaz de propostas para a resolução técnica das questões, para o entendimento na Rocinha de que, através da participação, o processo ganha a apropriação da comunidade e a potencialidade de se tornar mais adequado, real e ser concretizado. (SILVA, 2015 , informação verbal ${ }^{99}$ )

\section{REFLEXÃO: ARRISCAR SER MILITANTE}

A Peabiru e a Usina assumem publicamente o seu papel político como assessorias técnicas na luta pelo acesso e defesa por moradia digna e cidade para todos. $\mathrm{Na}$ realidade, esse amadurecimento é parte de um repertório de uma série de assessorias técnicas militantes, dentre as quais, a Peabiru e Usina, aqui pesquisadas, se inserem. A 
partir da definição deste papel, as assessorias vão assumindo ações e práticas que, por um lado, sublinham o seu sentido politizado, mas também fragilizam ou arriscam as organizações e afetam os seus técnicos diretamente. Como o caso de desenvolverem ou aplicarem práticas em processos de urbanização de favelas, para além dos que foram contratados, por acreditarem na sua necessidade e efetividade para o processo. Foi o que aconteceu com as consultorias e Oficinas realizadas com os moradores para o Batistini, feitos pela Peabiru (SANTOAMORE e MARQUES, 20 I 5, informação verbal $\left.^{100}\right)$. Muitas vezes, este empenho e dedicação não adquire um sentido quantitativo de medição, o que pode justificar a sua ausência em processos de contratação. Mesmo assim, estes sujeitos aplicam-nos se os considerarem contributos justificáveis e determinantes para o desenvolvimento do processo.

Também outros projetistas militantes que aqui fomos descrevendo em suas práticas, e que não integram assessorias técnicas politicamente engajadas no sentido público, tomaram decisões de risco nos processos de urbanização de favelas, considerando-as necessárias. Já falamos da abertura de uma filial do escritório de Toledo na Rocinha durante o desenvolvimento do Plano SócioEspacial. Muitas vezes estes riscos são induzidos pela imaturidade dos processos ou desconhecimento dos órgãos promotores e se demonstram na inadequação de valores, prazos ou definição dos produtos. Para o desenvolvimento do Cantagalo e Pavão-Pavãozinho, Jonathas Silva, Vera Tângari e equipe tiveram que ir acumulando outros projetos e contratos que possibilitassem a viabilização financeira da equipe, pois os projetos foram mais dispendiosos e demoram mais tempo do que inicialmente estava previsto.

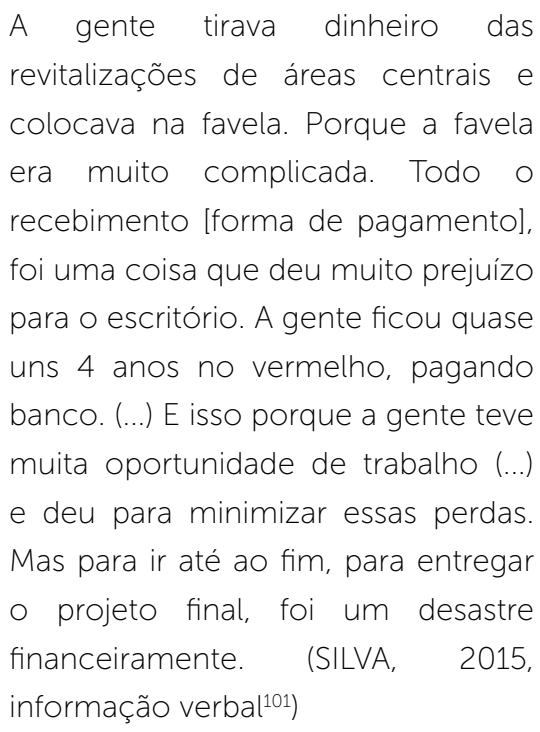

Contudo, Jonathas tinha entrado da licitação para o Favela-Bairro porque acreditava que aquele deveria ser o seu papel como arquiteto:

Eu acreditava que o arquiteto tinha
que se colocar naquela situação
mesmo (...). Eu achava que a coisa
inovadora estava no próprio pensar

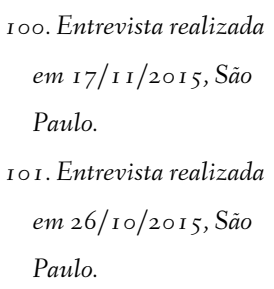


I02. Idem

I03. Idem a requalificação dos espaços não

usados da favela. Que era um pouco

a proposta do Favela-Bairro. (SILVA, 2015, informação verbal ${ }^{102}$ )

E sobre a dificuldade financeira que passaram enquanto equipe, toma para si um comentário feito pelo colega Luiz Carlos Toledo, numa palestra que participaram juntos sobre o trabalho na Rocinha. Questionado sobre o potencial de investimento empreendedor para jovens escritórios de arquitetos trabalharem com urbanização de favelas, dada a grande necessidade da cidade e do país, Toledo respondeu que achava que a favela não seria um trabalho para gerar lucro, e por isso ter um sentido de aposta empreendedora, ao que Jonathas ainda acrescenta: "Eu acho que trabalhos públicos deviam ser feitos envolvendo técnicos públicos, ou tendo contratações mas de forma racional, mas no fundo, ninguém fica rico fazendo favela!" (SILVA, 20 I 5 , informação verbal ${ }^{103}$ )

\section{REFLEXÃO: FRUSTRAÇ̃̃O \& MILITÂNCIA}

Não só nas reflexões acima colocadas, mas também na exemplificação e ilustração das práticas deste capítulo, fomos introduzindo outras chaves de análise e opiniões dos sujeitos sobre as suas práticas e partes dos processos que protagonizaram.

Das opiniões e depoimentos anteriores, mas sobretudo a partir das reflexões acima colocadas, um sentimento aparece permeando os relatos dos sujeitos militantes - a frustração. Essa sensação de frustração associada aos processos de urbanização de favelas, foi evidente recorrendo à entrevista como instrumento de base de pesquisa.

As entrevistas, que se aproximaram mais de conversas informais, do que de resposta a um questionário rigoroso, há uma grande parcela da conversa dedicada a um desabafo sobre os processos, às reflexões sobre as partes menos boas destas experiências. Esta 'necessidade de desabafar', leva-nos a questionar sobre o processo de urbanização de favelas em si, mas também sobre o motivo da insistência destes sujeitos perante estes mesmos processos. Mas olhando a partir destes casos e experiências dos sujeitos, o sentimento justifica-se na própria retrospectiva histórica.

Reconhecemos a inadequação da grande parte dos sistemas de contratação, seja por questões financeiras, de prazos ou da compreensão e conhecimento sobre um processo de urbanização de favelas. A esta inadequação, estão associadas limitações legais, burocráticas ou às vezes impostas pelos organismos promotores, como a dificuldade de acesso a informações, ou até à própria comunidade. Também a oposição face ao sentido inovador das propostas de alguns destes sujeitos, como anteriormente foi colocado, sobrecarregam a dificuldade de atuação. O tempo dos processos, das etapas entre levantamento, diagnóstico, projeto e 
obra, onde, muitas vezes surgem diferentes diretrizes a responder, ou não há a garantia que as etapas se efetuem, sobretudo a obra, acrescenta uma dose de grande incerteza destes projetistas sobre os processos e sobre a concretização do seu trabalho. Também a ausência recorrente dos projetistas em fase de obra, e a possibilidade, quase certa, de haverem adequações e transformações de projeto na fase de execução sem a sua participação, contribuí para um descrédito, por parte dos projetistas na materialização da sua dedicação.

Por fim, e lembramos a reflexão de Heloisa Rezende, sobre o fato de que, na verdade temos feito pouca urbanização de favelas. As dificuldades acima colocadas, e outras não abordadas, dificultam o teste ou avaliação sobre a forma de intervenção em favelas. Mesmo defendendo as práticas e os sujeitos militantes, Heloisa entende que não fizemos o suficiente para defender que esta é a melhor forma de atuar face a esta grande parcela do território urbano atual. (REZENDE, 20 I 6, informação verbal ${ }^{1 \circ 4}$ )

Mas mesmo na frustração, na incerteza, na falta de garantias, encontramos estes sujeitos a defender e reiterar as suas práticas e formas de olhar para a favela. $\mathrm{Na}$ dificuldade de atuação pública, dada as dificuldades de contexto (contratual ou outros), e mais recentemente, de crise económica e política, verificamos a tendência destes sujeitos se aproximarem de outras formas de atuação, principalmente através da formação de outros.

A maioria destes sujeitos são professores, e reconhecem que nessa atuação, têm potencial de impacto em outros sujeitos, difundindo as suas formas de agir e pensar sobre a favela, sobre as cidades e sobre o território e suas populações como um todo. A disseminação deste conhecimento acontece em algumas das práticas que fomos descrevendo, mas também dentro dos sistemas formais, na universidade, como professores em cursos de graduação de arquitetura e urbanismo, na participação em palestras públicas, ou pesquisas, na promoção de eventos para a discussão e divulgação da temática, e na orientação e colaboração com grupos de extensão e ação direta sobre comunidades $^{105}$. Outras iniciativas, como as Oficinas ATHIS realizadas pela Peabiru e com a participação e contribuição de outros sujeitos, alguns dos quais aqui mencionado, trazem, para além da formação, a possibilidade de troca de experiências, e instigação ao exercício de uma arquitetura, urbanismo, trabalho social, ou política pública, mais engajada, compromissada e reconhecedora das necessidades dos mais carentes ${ }^{106}$. Também nesse sentido, e para celebrar os 25 de formação da Usina, esta assessoria promoveu entre 20 I 5 e 20 I 6 uma série de eventos e produtos, entre debates, vídeo e lançamento de livro, para divulgar a atuação da Usina "como prática política" ${ }^{\circ 07}$.

Mesmo com o campo de atuação reduzido e incerto, estas práticas de disseminação

\author{
I04. Entrevista realizada \\ em ${ }_{17 / 10 / 2016}$, São \\ Paulo. \\ 105. Podemos avaliar \\ essa contribuição a \\ partir dos currículos \\ apresentados, na Parte \\ I, cap.I. \\ Io6. As Oficinas ATHIS \\ pretenderam criar um \\ diálogo multidisci- \\ plinar e multi-seto- \\ rial promovendo a \\ troca de conhecimentos \\ entre estudantes, mas \\ também profissionais \\ ativos de forma liberal \\ e em gestões públicas, \\ diversas organizações \\ da sociedade civil, \\ incluindo movimentos \\ de moradia e moradores \\ de assentamentos \\ informais, ou outros \\ lugares de precariedade \\ habitacional. Para mais \\ informações ver: www. \\ athis.org.br . A Peabiru \\ encontra-se no momen- \\ to a desenvolver um \\ filme, com o apoio do \\ CAU-SP (Conselho da \\ Arquitetura e Urbanis- \\ mo de São Paulo) para \\ divulgar e promover as
}


Oficinas e o trabalho de Assessoria Técnica para a Habitação de Interesse Social.

107. Mais informações sobre o Projeto Usina 25 anos, podem ser encontradas em http:// www.usina-ctah.org.br/

. Tanto o livro "Usina: entre o projeto e o canteiro" (Edições Aurora, 2015), quanto o documentário "Arquitetura como prática política" receberam também apoio do CAU SP para a sua elaboração. de conhecimento acumulado permitem, de alguma forma, a perpetuação das práticas militantes em urbanização de favelas, possibilitando a criação de outros caminhos e práticas, protagonizados por outros sujeitos, mas que mantêm vivo o espírito de ação política e engajamento face à realidade urbana que vivemos.

Cabe ressaltar que, até hoje, pouco se disseminou sobre as informações dos processos de aprendizado projetual daqueles que desbravaram caminhos, inventaram técnicas e trilharam a militância nesse campo. Este trabalho se coloca exatamente na perspectiva desse resgate histórico. Olhando para a atuação desses militantes, como trajetórias importantes a serem iluminadas. Enxergando na sua ação, que não se dá sem contradições, sem erros, nem mesmo sem frustrações, um repertório ético, técnico e estético a ser compreendido, analisado, e por que não dizer, atualizado permanentemente face à realidade muito dinâmica das favelas no país, as oportunidades atualmente escassas de financiamento público, e a potencialidade destes, de outros e dos sujeitos militantes que virão para atuação em assentamentos precários. 



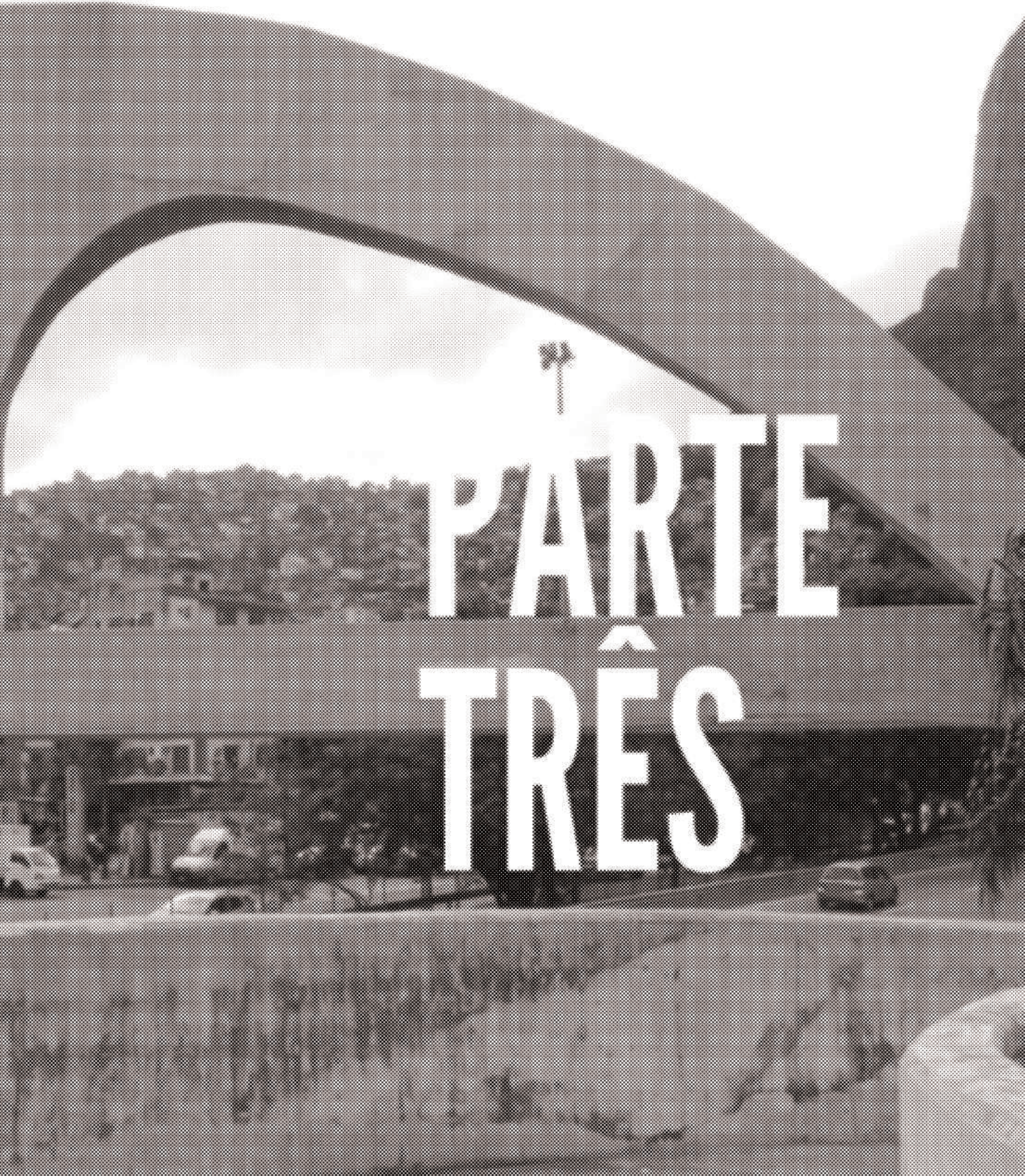




\section{NOTAS}

\section{CONCLUSIVAS}

Esta pesquisa pretendeu explorar um campo de conhecimento, delimitando-o, e ponderando a partir dele, sobre experiências de arquitetos em urbanização de favelas. As análises conceitual (capítulo I), contextual (capítulo 2) e das práticas usadas em cada caso (capítulo 3), permitem-nos uma reflexão sobre como se tem feito, como se faz e como pode ser feita a Urbanização de Favelas.

Admitimos mostrar uma visão tendencialmente positiva dos casos selecionados. Nos sujeitos e nas suas experiências em processos de urbanização de favelas, pretendíamos demonstrar e explorar o que nos parecia relevante como referência para uma atuação que se pretende transformadora física, social e politicamente. Acreditávamos que estes eram aspetos pouco iluminados, divulgados e de difícil acesso e que, portanto, mereciam nossa atenção.

Encontramos, nesta exploração, mais do que experiências transformadoras, sujeitos-referência. Indivíduos com formação oriunda de algumas das mesmas escolas de arquitetura e urbanismo que hoje formam arquitetos e urbanistas no Brasil, mas que se tornaram sujeitos de ação política no campo da urbanização de favelas, quando admitem nas suas práticas, nas suas ações, nas suas reflexões, existir uma intenção política, mesmo que inconsciente, de vontade de alteração dos contextos físicos e sociais injustos que lhes são colocados, ou perante os quais eles se colocam. Mais do que pela educação formal, estes sujeitos admitem ser formados pelas experiências práticas, pelos desafios reais, pelas reflexões pessoais, para uma atuação em favelas, e de certa forma questionam esse paradigma propondo introduzir essas mesmas questões quando são eles que tomam o papel de formadores.

A sua mobilização ou luta política ultrapassa as questões político-partidárias, ou associadas ao que comumente se entende por militância. Como aqui é colocada, a militância se traduz nas técnicas, na estética e na ética e no tensionamento entre as três, em propostas de levantamentos, formas de olhar e análise, de desenho e projeto, de possibilidades tecnológicas e de hipóteses de construção em favelas.

Também a partir destas ações, e dos questionamentos constantes dos sujeitos militantes, o campo de conhecimento em intervenções de favelas é renovado e transformado. Vimos como estes arquitetos 
e suas práticas contribuíram ao longo do tempo como referência de atuação, definição de parâmetros e proposições alternativas ao que era colocado. Esta possibilidade de inovadora e experimental, tanto é possível na superação de dificuldades e desafios, quanto no encontro, com outros sujeitos - moradores, poder público e outros técnicos - de vontades semelhantes, apoiadoras e estimuladoras para atuações revolucionárias. Alguns dos sujeitos apresentados admitem, inclusive, que é apenas num contexto favorável à militância em todos os seus agentes que as atuações do arquiteto e urbanista podem ter seu alcance transformador. O que demonstramos, no entanto, é que a militância e a sua prática, se dão mesmo em contextos menos favoráveis, e que o sujeito militante, é militante independentemente do seu papel, o do contexto da sua atuação.

O militante aqui explorado é o militante possível. Aquele que dentro de contingências estruturais realiza o processo, o levantamento, diagnóstico, projeto e obra historicamente possíveis (como nos termos do materialismo dialético) e permitidos. Não é ainda o militante da revolução na produção do espaço nas favelas, mas é o militante da revolução da prática de uma arquitetura que, no Brasil e no mundo, ainda se mantém como uma profissão muito elitizada.

Nos sujeitos, nos casos em que participaram e nas práticas por eles empregues e aqui apresentadas, encontramos uma contribuição técnica / estética / ética e política para a atuação em favelas, mas sabemos que se trata de um olhar para casos em que, a atuação para e com os mais pobres, ainda depende de apoios externos e por isso, se sujeita às suas definições, e muitas vezes, limitações e contradições. E por mais que não tenhamos focado, no âmbito desta pesquisa, nas contradições e concessões em que se inserem as atuações destes sujeitos, também encontramos nos seus depoimentos, alguma incredibilidade, alguma desistência e muita frustração sobre a atuação em favelas.

Se por um lado encontramos neles muita contribuição para o campo do conhecimento, no sentido social emancipado, as práticas idealizadas pelos sujeitos militantes estão longe de serem amplamente testadas e materializadas. Muitos destes exemplos 
foram alterados na sua materialização, não chegaram a ser concluídos em projeto ou em obra, tomaram tanto tempo que sua concepção deixou de ser adequada, ou nem chegaram a ser retiradas para fora do papel.

Para além da frustração daí derivante, sabemos que no percurso de cada sujeito estudado, aconteceram outros conflitos de todas as ordens. Dificuldades de entendimento e de acesso na favela, de comunicação com moradores, problemas na relação com contratantes e terceirizados, pactuações em que foram feitas concessões. Mas acima disso, vimos nos militantes uma capacidade de refletir sobre si, sobre seus conflitos e sua inserção na profissão, e ainda, de se reinventar mesmo diante das frustrações de ver seu empenho e dedicação resultar muitas vezes em tão poucas transformações, comparadas com as que havia idealizado e projetado.

Para avaliarmos todo o alcance e limite de processos de urbanização de favelas feito por militantes precisaríamos tomar outras frentes de trabalho. Recorrer ao estudo de campo e aos demais agentes, verificar no território quais seus impactos e apropriações. Mas mais que isso, precisaríamos implementar mais, arriscar mais, testar mais urbanizações de favela feita nestes propósitos. Ainda estamos longe de implementar na prática todas as idealizações conceituais aprendidas e apreendidas. E termos um repertório suficiente para defendermos a sua implementação. Mas no que conseguimos avaliar, encontramos processos respeitosos, que valorizam os contextos e questionam preconceitos, e ao mesmo tempo, e por isso, sugerem soluções com potencial transformador e que deve ser perseguido e explorado.

Não coube neste trabalho tratar explicitamente das relações do militante com as pessoas na favela, na perspectiva do morador. Nem com a relação com o poder público em alguns conflitos apresentados, pela perspectiva do gestor ou gerenciadora. Reconhecemos aí, alguma limitação da pesquisa, mas também possibilidades de suas derivações.

Dos dados coletados, entre os documentos gráficos e escritos, os depoimentos e os sujeitos, abrem-se ainda outras possibilidades de pesquisa, de análise e de reflexão. Ainda não estão esgotadas, através 
dos desenhos e representações gráficas, análises sobre os alcances e limites destas ferramentas, e a experimentação de outras para a intervenção em favelas. Sobre as representações gráficas, ainda ficamos aquém num aprofundamento sobre as leituras e diagnósticos, uma análise sobre as propostas, e a verificação da sua implementação ou transformação em obra.

Pelos casos aqui abordados, poderia ser tomada ainda a análise com um foco nas políticas, na sua avaliação tanto na compatibilização do trabalho do projetista, quanto no que elas possibilitam ou retraem, e que outras nuances no campo político têm impacto direto sobre os levantamentos, diagnósticos, projetos e obras em favelas. Fomos testando ao longo do texto algumas considerações sobre o assunto, mas a partir destes casos, muito mais poderia ser dito. Houve, contudo, a clara intenção de embasar uma reflexão para o cenário político atual no campo da urbanização de favelas, como chegamos até aqui e para onde vamos, e como nestas transformações de cenário o profissional da arquitetura e urbanismo tem encontrado o seu espaço de atuação.

Por fim, se não pretendemos enumerar uma cartilha de regras a ser seguidas para que a atuação de tal arquiteto seja militante, até porque cada prática e ação depende de seu contexto, seu programa, sua política, dos restantes agentes, e da favela, ensaiamos um questionamento do lugar deste profissional.

Optamos antes por enfocar no que há de aprendizado acumulado através de um registro histórico e debate, e na sua importância e contribuição, para a disseminação deste conhecimento sobre seu possível aprofundamento no campo profissional e acadêmico na urbanização de favelas.

Não intencionamos a mimetização dos sujeitos militantes, das suas práticas, ações, metodologias, técnicas ou estéticas. Sabemos que nesta pesquisa, abordamos as práticas de um número ínfimo deles. Mas utopicamente esperamos que este campo de atuação seja expandido tanto nas possibilidades como no número de sujeitos mobilizados para um exercícios que ambicionem lugares menos precários, menos preconceituosos, mais integrados, mais justos e mais emancipadores. 


\section{REFERÊNCIAS}

ALMEIDA, Marco Antonio Plácido de. Urbanização de favelas em Diadema, no periodo de I 983 a I 98 9. Resumo de dissertação de mestrado em Engenharia Civil da Escola Politécnica da USP. São Paulo, I 994.

BALTAZAR, Ana Paula; KAPP, Silke. Por uma Arquitetura não planejada: o arquiteto como designer de interfaces e o usuário como produtor de espaços. Impulso (Piracicaba), 2006 , v. I 7, p. 93-103. Disponível em: http://www.mom.arq.ufmg.br/mom/05_ biblioteca/textos_grupo/mesas/kapp.htm Acesso em: I 3/02/20 I 7

BLANK, Gilda. Brás de Pina - Experiência de Urbanização de Favela. In: VALLADARES, L.P (Org.). Habitação em questão. Rio de Janeiro: Zahar Editores, I 980. p.93-I 24

- Experiência de urbanização de favela carioca, Brás de Pina. Dissertação de mestrado em Planejamento urbano e Regional. Rio de Janeiro, COPPE/PUR/UFRJ, I 977.

BONDUKI, Nabil. Origens da habitação social no Brasil - Arquitetura Moderna, Lei do Inquilinato e Difusão da Casa Própria. São Paulo: Estação Liberdade/ FAPESP, I 998.

. Habitação e Autogestão. Construindo territórios de utopia. Fase. Rio de Janeiro, I 992 .

BUENO, Laura M. M. Projeto e favela: metodologia para projetos de urbanização de favela. Tese de Doutorado - Faculdade de Arquitetura e Urbanismo da Universidade de São Paulo, São Paulo, 2000.

CARDOSO, Adauto L. Urbanização de Favelas no Brasil: Revendo a Experiência e Pensando os Desafios. IPPUR/UFRJ. XII Encontro da Associação Nacional de PósGraduação e Pesquisa em Planejamento Urbano e Regional, Belém, 2007

COELHO, Marta Cirera Sari. Espaço de Direitos É mais que Direito a Espaço. O Processo de Urbanização de Favelas em Diadema (1983 - 2008). Dissertação de Mestrado em Serviço Social Pontifícia Universidade Católica de São Paulo (PUC-SP). São Paulo, 2008 .

DENALDI, Rosana. Politicas de Urbanização de Favelas: Evolução e Impasses. Tese de Doutorado - Faculdade de Arquitetura e Urbanismo da Universidade de São Paulo, São Paulo, 2003 .

FATHY, Hassan. Construindo com o povo: arquitetura para os pobres. Rio de Janeiro: Salamandra. São Paulo: Editora da Universidade de São Paulo. I 980.

FERREIRA, Lara e LEITÃO, Karina O. O Diagnóstico na Urbanização de Assentamentos Precários: notas a partir de experiências recentes no Brasil. II Congresso Internacional de Habitação Coletiva Sustentável, São Paulo, 20 I6. 
FERREIRA, Paulo Emilio B. Urbanização de favelas: metodologias e ação no contexto contemporâneo. Proposta de Sessão Livre XVI ENANPUR - Belo Horizonte, 2015.

. Urbanização de Favelas vs Desfavelamento: Notas Sobre Uma Operação Paulistana. In: $3^{\circ}$ CIHEL. Anais do $3^{\circ}$ CIHEL - Congresso Internacional da Habitação no Espaço Lusófono. São Paulo: FAUUSP, 20 I 5.

FJP, Fundação João Pinheiro - Centro de Estatística e Informações. Déficit Habitacional no Brasil 20 I I-20 I 2. Belo Horizonte: Fundação João Pinheiro - Centro de Estatística e Informações, 2015.

FONSECA, C. e MAGNI, C. T. Homenagem a Colette Pétonnet. Horiz. antropol. [online]. 20 I 4, vol.20, n.4 I, pp. 405-4 I I. Disponível em: dx.doi.org/I o. I 590/So I 04 71 832014000100015 Acesso em: I3/01/2016

GARCIA, Marília F. e NUNES, Edison (org.). Formação e prática profissional do arquiteto - três experiências em participação comunitária: Erminia Maricato, José F. Calazans, Luis Fingerman. In: Espaços \& Debates. Revista de Estudos Regionais e Urbanos, nº8. Cortez Editora. São Paulo, Jan/Abr i 983· p.79-95

HAM, C. e HILL, M. The policy process in the modern capitalist state. Harvester Wheatsheaf, Londres, I 993, segunda edição. Versão digital em português. Adaptação e Revisão: Renato Dagnino.

IBGE - Instituto Brasileiro de Geografia e Estatística. Censo Demográfico: BRASIL, 2000. Rio de Janeiro: IBGE, 2000.

. Censo Demográfico: BRASIL, 20 I о. Rio de Janeiro: IBGE, 20 г.

. Ministério do Planejamento, Orçamento e Gestão. Aglomerados subnormais Primeiros resultados. IBGE, Rio de Janeiro, $20 \mathrm{I}$.

I URBFAVELAS. Anais do I URBFAVELAS _ Seminário Nacional sobre Urbanização de Favelas. São Bernardo do Campo: UFABC, 20 I 4 . Disponível em: http://www. sisgeenco.com.br/sistema/urbfavelas/anais/ Acesso em: I3/o I/20 I6

KAPP, Silke et al. Arquitetos nas favelas: três críticas e uma proposta de atuação. IV Congresso Brasileiro e III Congresso Ibero-Americano Habitação Social: ciência e tecnologia "Inovação e Responsabilidade". Florianópolis: UFSC, 20 I 2. Disponível em: http://www.mom.arq.ufmg.br/mom/o5_biblioteca/textos_grupo/mesas/kapp.htm Acesso em: I3/02/201 7

KAPP, Silke; NOGUEIRA, Priscilla; BALTAZAR, Ana Paula. Arquiteto sempre tem conceito - esse é o problema. In: Projetar, 2009, São Paulo. Projeto como investigação: Antologia. São Paulo : Altermarket, 2009. Disponível em: http://www.mom.arq.ufmg. br/mom/05_biblioteca/textos_grupo/mesas/kapp.htm Acesso em: I3/02/20 I 7

KATINSKY, Julio. Técnica, Tecnologia e Educação em Países Subdesenvolvidos. In: MASCARÓ, Lucia (coord.). Tecnologia \& Arquitetura. Nobel. São Paulo, I 989. p.6 I86 
LABHAB, MARICATO, Erminia et al. (org.). Parâmetros Técnicos para a Urbanização de Favelas. FUPAM/LABHAB/FAUUSP - FINEP/CEF. São Paulo, I 999. Arquivo digital, disponível em: http://www.fau.usp.br/depprojeto/labhab/biblioteca/produtos/ paramtecnicos_urbafavelas.pdf Acesso em: I3/02/201 7

LAMAS, Bruno. O Trabalho Abstrato como Apriorismo Tácito na Génese da Sociologia Dita 'Urbana'. Apresentação no debate "Niemeyer, Brasília e a Cidade Moderna", organizado pela Unipop e revista Imprópria. Lisboa, 2007. Disponível em http://versus. planetaclix.pt/artigos/artigo\%2oSociologia\%2oUrbana.htm Acesso em: 28/07/20 I 4.

LEITÃO, Karina. Report - Brazilian Experience Federal Program PAC Urbanization: Successful Approaches to National Slum Upgrading and Prevention Policies and Programs. BID. São Paulo, $20 \mathrm{I} 2$.

A dimensão territorial do Programa de Aceleração do Crescimento: um estudo sobre o PAC no estado do Pará e o lugar que ele reserva à Amazônia no desenvolvimento do país. Tese de Doutorado na FAUUSP. São Paulo, 2009.

LEITÃO, Karina e FERREIRA João Sette W. Aspectos Fisicos, Urbanisticos e Arquitetônicos. In: MAGALHÃES, F.; VILLAROSA, F. (editores). (Org.).

Urbanização de Favelas: Lições Aprendidas no Brasil. I Ed. São Paulo: Fupam, 20 I 2a, V. , P. I-48.

LIMA, Fellipe de Andrade Abreu e. Ética e estética nas arte, arquitetura e urbanismo contemporâneos - uma crítica realista. Pós. Revista do Programa de Pós-Graduação em Arquitetura e Urbanismo da FAUUSP, São Paulo, n. 28, p. I 58 - I 8 I , dec. 20 I ०. ISSN 23 I 7-2 762. Disponível em: <http://www.revistas.usp.br/posfau/article/view/43706>. Acesso em: I3/02/1 7

LOPES, João Marcos de Almeida. Sobre arquitetos e sem-tetos - técnica e arquitetura como prática politica. Tese de Livre-docência no Instituto de Arquitetura e Urbanismo da Universidade de São Paulo IAU USP. São Carlos, 20 I I. Arquivo digital disponível em: http://www.usina-ctah.org.br/sobre-arquitetos-e-sem-tetos.html\#sthash.vnfdRBiu.dpuf Acesso em: I3/02/1 7

. Em memória das mãos: o desencantamento da técnica na arquitetura e no urbanismo. Tese de Doutorado em Filosofia e Metodologia das Ciências da Universidade Federal de São Carlos. São Carlos : UFSCar, 2006.

LOPES, João Marcos de Almeida e PULHEZ, Magaly M. De molde a contramolde: (re) construindo questões sobre a urbanização de favelas. Cadernos IPPUR/UFRJ, v. 22, p. 67-88, 2008a.

. Favelas e Tecelões: costurando novas tecnologias para urbanização de favelas. In: Paula Peyloubert; Laura De Salvo; Dante Pipa. (Org.). Ciencia y Tecnología para el hábitat popular. Desarrollo tecnológico alternativo para la producción social del hábitat.. I ed.Buenos Aires: Nobuko, 2008b, v. , p. 329-34 I.

MARICATO, Erminia Habitação e Cidade. São Paulo: Atual Editora, I 998.

. Metrópole na periferia do capitalismo: ilegalidade, desigualdade e violência. São Paulo: Hucitec, I 995. 
MASCARÓ, Lucia (coord.). Tecnologia \& Arquitetura. Nobel. São Paulo, I 989.

MINISTÉRIO DAS CIDADES. Manual de Instruções para Contratação e Execução dos Programas e Ações do Ministério das Cidades inseridos na segunda fase do Programa de Aceleração do Crescimento - PAC 2. Brasília: MCidades, 20 I 3.

MORETTI, Ricardo et al. Urbanização de assentamentos precários no âmbito do Programa de Aceleração do Crescimento na Região do ABC. Santo André: UFABC, 2015. Chamada MCTI/CNPq/MCidades no I I/20 I 2.

MORETTI, Ricardo et al. O PAC UAP na região do ABC . In: I Urbfavelas. São Bernardo do Campo, UFABC. 20 I 4.

NAKAMURA, Milton. O controle urbano nas favelas urbanizadas, o caso da região do $A B C$. Dissertação de Mestrado em Planejamento e Gestão do Território UFABC. São Bernardo do Campo. UFABC, 20 I 4.

OLIVEIRA, Fabricio et al. (org.). Planejamento e Conflitos Urbanos: experiências de luta. ETTERN / IPPUR / UFRJ. Rio de Janeiro, 20 i 6.

PALLAMIN, Vera. Aspectos da relação entre o estético e o politico em Jacques Rancière. Risco (São Carlos), v. ı 2, p. 6- I 6, 20 I o. Disponível em www.fau.usp.br/wp-content/ uploads/20 I 5/o9/Aspectos_relacao_estetico_politico_Jacques_Ranciere.pdf Acesso em: $10 / 02 / 2017$

PEREIRA, Marina Barrio. Projeto de Melhoria Habitacional. Metodologia de Trabalho em Urbanização de Assentamentos Precários. Trabalho Final de Graduação em Arquitetura e Urbanismo, FAUUSP. São Paulo, 20 I 3.

PÉTONNET, Colette. Itinerário de uma antropóloga em meio operário. In MELLO. M. A. S. et al. (org.). Favelas cariocas: ontem e hoje. Rio de Janeiro: Garamond, 20 I 2, p. 475-490.

. "Introduction ", "Conclusion ", «Postface de C. Choron-Baix » in PÉTTONET, C. On est tous dans le brouillard: essai d'ethnologie urbaine. Paris, Ed. du CHTS, 20 I o. p. 9-25, 503-530.

PETERSEN, Lu. Militância, favela e urbanismo. FGV. Rio de Janeiro, 2009.

PETRAROLLI, Juliana. O tempo nas urbanizações de favelas: contratação e execução de obras do PAC no ABC. Dissertação de Mestrado em Planejamento e Gestão do Território UFABC. São Bernardo do Campo, 2015.

PINHEIRO, Jair. O sujeito da ação política: notas para uma teoria. Lutas Sociais (PUCSP), São Paulo, v. 3, I 997, p. I 43-163.

PULHEZ, Magaly M. O arranjo gerencial: Estado, empresas de engenharia e arquitetos nos cotidianos de gestão da politica habitacional em São Paulo. Tese de Doutorado em Arquitetura e Urbanismo no Instituto de Arquitetura e Urbanismo da Universidade de São Paulo, IAU USP, São Carlos, 20 I 4.

Fronteiras da desordem: saber e oficio nas experiências de Hélio Oiticica no Morro da Mangueira e de Carlos Nelson Ferreira dos Santos em Brás de Pina. Revista do Instituto de Estudos Brasileiros, v. 47, 2008, p. 93-I I 4. 
- Espaços de favela, fronteiras do ofício: história e experiências contemporâneas de arquitetos em assessorias de urbanização. Dissertação de Mestrado em Arquitetura e Urbanismo no Instituto de Arquitetura e Urbanismo da Universidade de São Paulo, IAU USP, São Carlos, 2007b.

PULHEZ, Magaly M.; REZENDE, H. Muita Arquitetura, alguma politica: Considerações sobre novas e velhas práticas nas urbanizações de favelas em São Paulo-Brasil. In: Anais do 20 Congresso Internacional da Habitação no Espaço Lusófono: Habitação, Cidade, Território e Desenvolvimento. Lisboa, Portugal: 20 I 3.

REZENDE, Heloisa Diniz. Forma. Reforma. Desforma: o novo formato da politica pública para favelas. Dissertação de Mestrado, FAUUSP. São Paulo, 20 I 5.

RIBEIRO, Manoel. Estratégia Sociológica de Intervenção em Favelas. Projecto Serrinha: Uma experiência de inclusão urbanistica e sociocultural. In: Arquitectura e Vida $\mathrm{n}^{\mathrm{o}}{ }_{50}$, 2004, p.32-37.

SAMORA, Patricia R. Projeto de Habitação em Favelas: Especificidades e parâmetros de qualidade. Tese de doutorado, FAUUSP, São Paulo, 2009.

SANTO AMORE, Caio. Entre O Nó e o Fato Consumado, o Lugar dos Pobres na Cidade. Um estudo sobre as ZEIS e os impasses da Reforma Urbana na atualidade. Tese de Doutorado em Planejamento Urbano e Regional, FAUUSP. São Paulo, 20 I 3.

SANTO AMORE, Caio et al. Precariedades habitacionais: um ensaio de quantificação e qualificação, uma metodologia de projeto para intervenção em favelas. In Anais do I URBFAVELAS. São Bernardo do Campo: UFABC, 20 I 4.

SANTOS, Carlos Nelson Ferreira dos. A cidade como um jogo de cartas. São Paulo: Projeto Editores, I 988.

. Movimentos Urbanos no Rio de Janeiro. Rio de Janeiro: Zahar Editores, I 98 I.

. Como e quando pode um arquiteto virar antropólogo? In: VELHO, G. O desafio da cidade: novas perspectivas de antropologia brasileira. Rio de Janeiro: Editora Campus, I 980 .

. Velhas Novidades nos modos de urbanização brasileiros. In: VALLADARES, L.P (Org.). Habitação em questão. Rio de Janeiro: Zahar Editores, i 980 b. p. I 7-47.

. Habitação - O que é mesmo que pode fazer quem sabe? In: VALLADARES, Lícia do Prado (Org.). Repensando a Habitação no Brasil. Rio de Janeiro: Zahar Editores, I 982 .

SCHILLER, Friedrich. Cartas sobre a educação estética da humanidade. São Paulo: EPU, I99 I

SILVA, Jonathas Magalhães P. Pensar a Habitação de Interesse Social. Exercício do desenho do amanhã, que já poderia existir hoje. Resenhas Online, São Paulo, ano I 4, n. I 58.04 , Vitruvius. 20 I 5. Disponível em http://www.vitruvius.com.br/revistas/read/ resenhasonline/ I 4. I 58/5448. Acesso em 28/02/20 I 6 
Plano Sócio Espacial da Rocinha - plano, projetos e obra: conflitos e contradições. In: ZUQUIM, M. L. e DOTTAVIANO, M. C. L. (Org.). (Org.). Práticas recentes de intervenção urbana em áreas informais na América Latina. I ed.São Paulo: FAUUSP, $20 \mathrm{I} 4$.

TOLEDO, Luiz Carlos. Uma experiência de participação: técnicos e moradores na elaboração do Plano Diretor Sócio Espacial da Rocinha in LAGO, L. C. (org.) Olhares sobre a metrópole do Rio de Janeiro: política urbana e gestão pública. Rio de Janeiro: Letra Capital: Observatório das Metrópoles: IPPUR/UFRJ: FASE, 20 г $\circ$.

TURNER, John F. C. Freedom to Build: Dweller Control of the Housing Process. New York: Macmillan, 1972.

Housing by People: Towards Autonomy in Building Environments, Ideas in progress. London: Marion Boyars, 1976.

. O Desafio do Apoio à Autogestão. Tarefas para o arquiteto. In: MASCARÓ, Lucia (coord.). Tecnologia \& Arquitetura. Nobel. São Paulo, I 989. p. I O2- I 19

VAINER, Carlos. Introdução in OLIVEIRA, Fabricio [et al] (org.). Planejamento e Conflitos Urbanos: experiências de luta. ETTERN / IPPUR / UFRJ. Rio de Janeiro, 20 I6, P.II-I 5 .

VALLADARES, Licia do Prado. A invenção da favela: do mito de origem a favela.com. Rio de Janeiro: FGV, 2005.

. (org.) (1998). A Escola de Chicago: impactos de uma tradição no Brasile na França. Belo Horizonte e Rio de Janeiro: Ed. UFMG / IUPERJ.

. Habitação em questão. Rio de Janeiro: Zahar Editores, I 980.

VENTURA, Zuenir. Cidade Partida. Rio de Janeiro. Companhia das Letras, I 994.

VILAÇA, Ícaro e CONSTANTE, Paula (org). Usina: entre o projeto e o canteiro. São

Paulo: Edições Aurora, 2015. 


\section{DOCUMENTÁRIO}

NUNES, Gabriela et al. Arquitetura como Prática Política - 25 anos de experiência da

Usina. Documentário. Usina CTAH. São Paulo, 20 I6. Disponível em https://www. youtube.com/watch?v=HgrnvEhKFSw Acesso em: I3/0 I/20 I 7

\section{ENTREVISTAS}

GERMANO, Wagner. Entrevista concedida à autora em 27/ I I /20 I 5, São Paulo.

NAKAMURA, Milton. Entrevista concedida à autora em I 4/I 2/20 I 5, São Paulo.

REZENDE, Heloisa Diniz. Entrevista concedida à autora em i 7/ ıo/20 ı 6, São Paulo.

RIBEIRO, Manoel. Entrevista concedida à autora em 20/ I I /20 I 5, Rio de Janeiro.

SANTO AMORE, Caio e MARQUES, Alexandre. Entrevista concedida à autora em I 7/I I/20I 5, São Paulo.

SILVA, Jonathas Magalhães. Entrevista concedida à autora em 26/1 o/20 I 5, São Paulo.

TÂNGARI, Vera Regina. Entrevista concedida à autora em 23/ I I/20 I6, Rio de Janeiro.

TOLEDO, Luiz Carlos. Entrevista concedida à autora em 23/ I I/20 I 5, Rio de Janeiro.

\section{ENCONTROS GE_FAVELAS}

Milton Nakamura e Lígia Lupo. Projeto Chafik-Macuco - a gestão pública, realizado em 05/10/20 I 5, São Paulo.

José Baravelli e Renata Moreira. Projeto Chafik-Macuco, realizado em I 9/ı ı/20 I 5, São Paulo.

Magaly Pulhez. Habitação, prática profissional e gestão pública. Trajetória de pesquisa, realizado em 26/09/2016, São Paulo. 


\section{SITES}

Site Athis, disponível em: http://www.athis.org.br/

Site Chicala, disponível em: www.chicala.org

Site M\&T arquitetura, disponível em: http://www.mtarquitetura.com.br/

Site MOM, disponível em: www.mom.arq.ufmg.br/mom/index.html

Site MPS associados, disponível em: http://www.mpsassociados.com.br/portfolioarquitetura.html

Site Paulo Moreira arquiteto, disponível em: www.paulomoreira.net

Site Peabiru TCA, disponível em: http://www.peabirutca.org.br/

Site Projeto Usina 25, disponível em: http://usina25.weebly.com/

Site Renova SP, disponível em: renovasp.habisp.inf.br/concurso/info/apresentacao

Site Unas, disponível em: www.unas.org.br

Site Usina CTAH, disponível em: http://www.usina-ctah.org.br/

Obras marxistas disponíveis em versão digital em: bibliotecacomuna.blogspot.com.

br/20 I 2/o3/o-capital-karl-marx-completo-2-edicoes.html ; www.pstu.org.br/sites/ default/files/biblioteca/marx_engels_manifesto.pdf ; www.scientific-socialism.de/ LeninMaterialismoMilitanteCap I.htm 


\section{CRÉDITOS IMAGENS}

CAPA

Elaboração: Gabriel Vieira Kolisch

ABERTURAS DE PARTES

PARTE ZERO

Parque Oziel, Campinas

Fonte: própria, 2016

\section{PARTE UM}

UERJ, Rio de Janeiro

Fonte: própria, 2016

\section{PARTE DOIS}

Rocinha, Rio de Janeiro

Fonte: própria, 2016

\section{PARTE TRÊS}

Rocinha, Rio de Janeiro

Fonte: própria, 2016

\section{IMAGENS DE CURRICULOS}

CARLOS NELSON F. DOS SANTOS

Fonte: SANTOS, 1988

\section{MANOEL RIBEIRO}

Fonte: imagem pessoal, cedida pelo sujeito

\section{LUIZ CARLOS TOLEDO}

Fonte: cedida por Jonathas Silva

\section{VERA TANGARI}

Fonte: imagem pessoal, cedida pelo sujeito

\section{JONATHAS SILVA}

Fonte: própria, 2016

VERA TANGARI

Fonte: imagem pessoal, cedida pelo sujeito

\section{PEABIRU TCA}

Fonte: cedida por PEABIRA TCA

\section{CAIO SANTO AMORE}

Fonte: imagem pessoal, cedida pelo sujeito

\section{ALEXANDRE MARQUES}

Fonte: imagem pessoal, cedida pelo sujeito

\section{USINA CTAH}

Fonte: cedida por USINA CTAH

\section{WAGNER GERMANDO}

Fonte: cedida por USINA CTAH

\section{HELOISA REZENDE}

Fonte: imagem pessoal, cedida pelo sujeito

\section{MILTON NAKAMURA}

Fonte: imagem pessoal, cedida pelo sujeito 